

$\nabla, 39$.

HIROS:II O"S: IIMA,

Biological Laboratory,

Fifth Kōtō-Gakkō,

Kumamoto, Japan:

Division of Nollusiks Sectional Library 


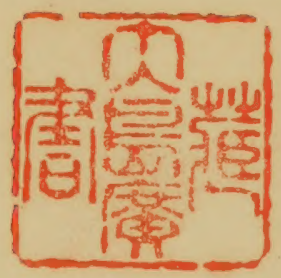


Hirase, Yoichuio

Kairui Tebikigusa.

ग5

Gude to shalls.

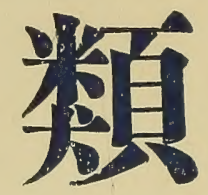

瀨

與

京

都

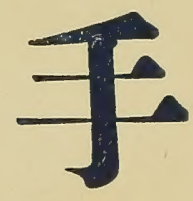

郎

本

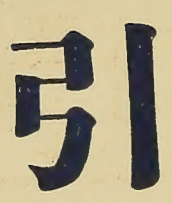

者

瀨

介

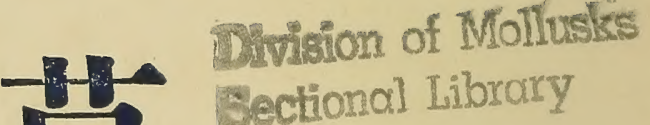

舘

军

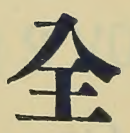

行

KMoTo, 1909. 


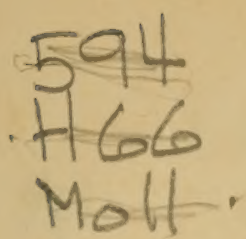

349318

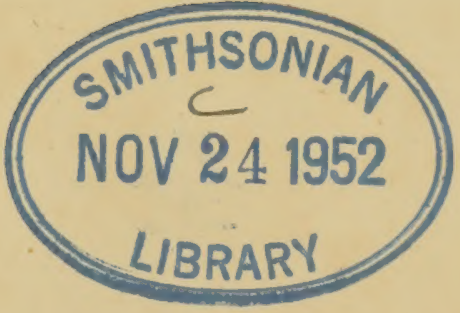




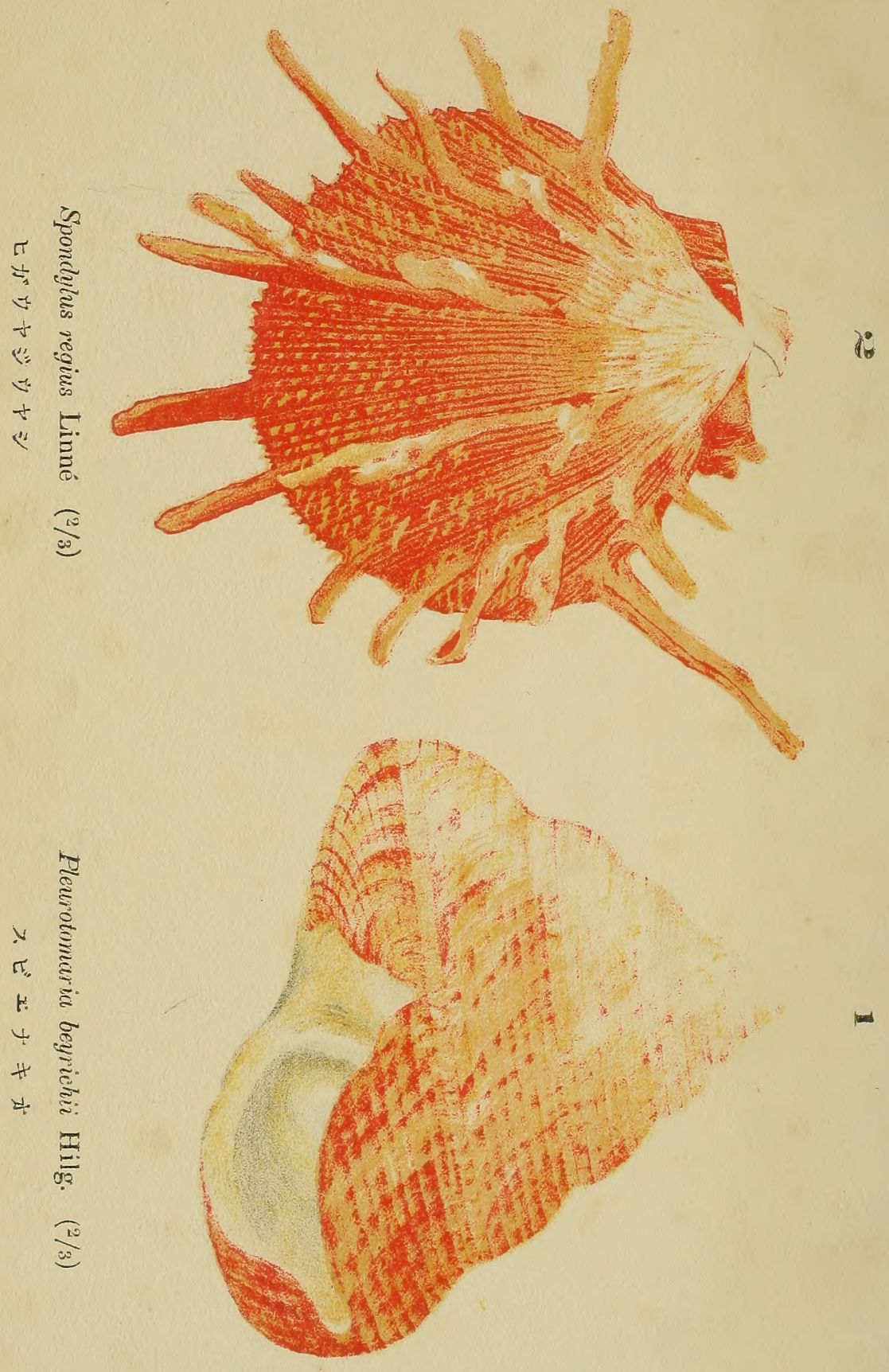



ひて帶長類種に知貝

し、地蛇にご友

。斯にの亞概ん尔類 學達如く算で瀨 考?乞゙せ與手 攻 $\begin{aligned} & 3 \\ & \text { 南 }\end{aligned}$ 笔が南。る虏郎 せ故北而南君草

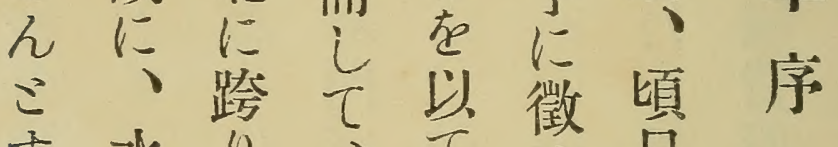

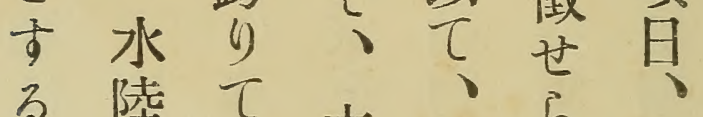
る 陸さ本品ら 㟟 具は心の风手 䳬類權多多引 めの太四塞草 に豐の面よむこ は亩寒環り皆い 、な帶らい界多 實る地专人中心 にこよにばの書 天气り海、具苨 與は、苍動類著 の世南以物はは 邦界はて界、し 土無臺?中總、 比灣、数 稿 謂にの地昆五成 子し熟形虫萬る 
手斯い年極に學具り景 に學て具め發教類、に 成の朝類 $て$ 展室學初、 り大鮮の稀しにひめ明 て家及菟な、附專 ひ集り各屬門其十 新合支に。科せ家の年 屬衆那力君のるに教、 新國にめは專標し授我 種費ま、、門本てのが の府で探動家の、職大 發大擴集物を基廣に學 眊學韭地學輩礎々 就に せのせの者出こ本け動 ら呚ら箶に世作邦る物 れ授れ圍あし世心恩學 たいんはこり具師の ろドこ、さ踓。類、專 も少也獨るも爾夿ド攻 のトりりる、來探り科 、儿口本、具、集卜在 實 、標 邦 非類動しル設 にピ本に常學物、、置 數ルの限の學以モせ 百 ス 鑑 ら熱 專はて のブ定ず攻種今ルる二

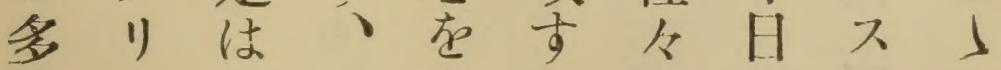
き1、今以るの代に に氏專はてる方動はあ 達の莚多の面物、た 


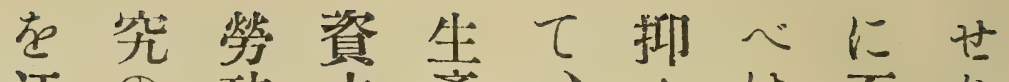

迂の功少產〉名け至り

遠項相こ業此一れ视。

無目償虑のの國ばり君

用をは要發調に心には

の擇ざ達香產又踓、

學ばるる は可方 以名斯

問んのこ、不るで、策

こ狀こ期十動自君の

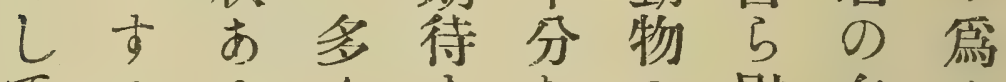

てるるく立なの慰名め

、意がしべる種藉譽に

$己$ 向故て か以屬す は莫

れをに上在る新大

有、そさ調に屬の

顧し學のる查足種資

る、者効な斯守 るの金

も又は果り學るへ學を

の世多は。應はし名費

鮮人く却然角人次さ

しはこつる。動

䓀 ᄂ

然類虎顯、學、砝

りの捨著分開發永气

、如七な類け展遠家

三而き十 $引$ 學

し純、すは朽基

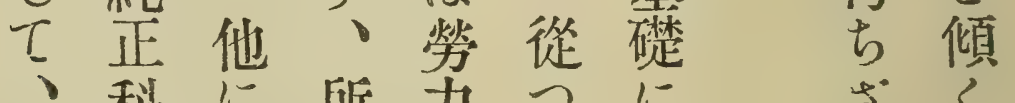

科所为 2 保

漫學研謂こてしてる る 
具本所の人せ及本こに 類書な篤のら菓湏い應

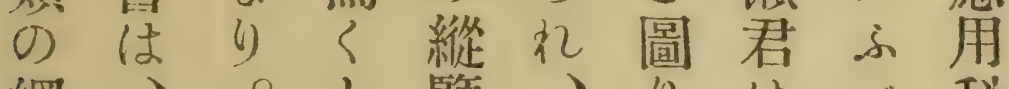

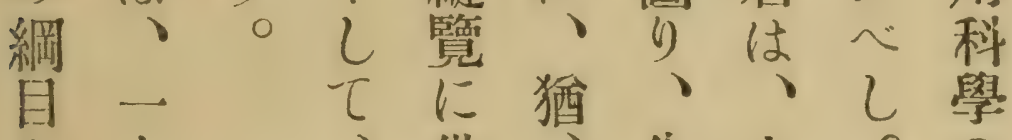
芷小、供、先家。の 分冊而世將に産不 少加九來は老振

に

各過

科 き

目

()

下踓

に 8

は、

最

有 新

用 の

な分

乃 類

實 法

例

尼從

擧 つ

げて

$\tau$.

、本

子こに月抛

高於刊

學々い小、

にのて介-

忠計は類身

實畫斗雜を

な瀨誌委

るり介を和

は。舘發七

、君在行至

余の建し䧼

の 社設、の

常會 L今業

ににて、

敬真文從

服献所、事

し 藏此 し

$\tau ん の の 、$

措こ標書斯

加古本學

一 邦

竹産

ざるを著の

万志衆述普

万e

吸

个

す

b

風

あ

る

は

本

末

在

過

$\tau$

3

の

甚 四

L

き

o

の 


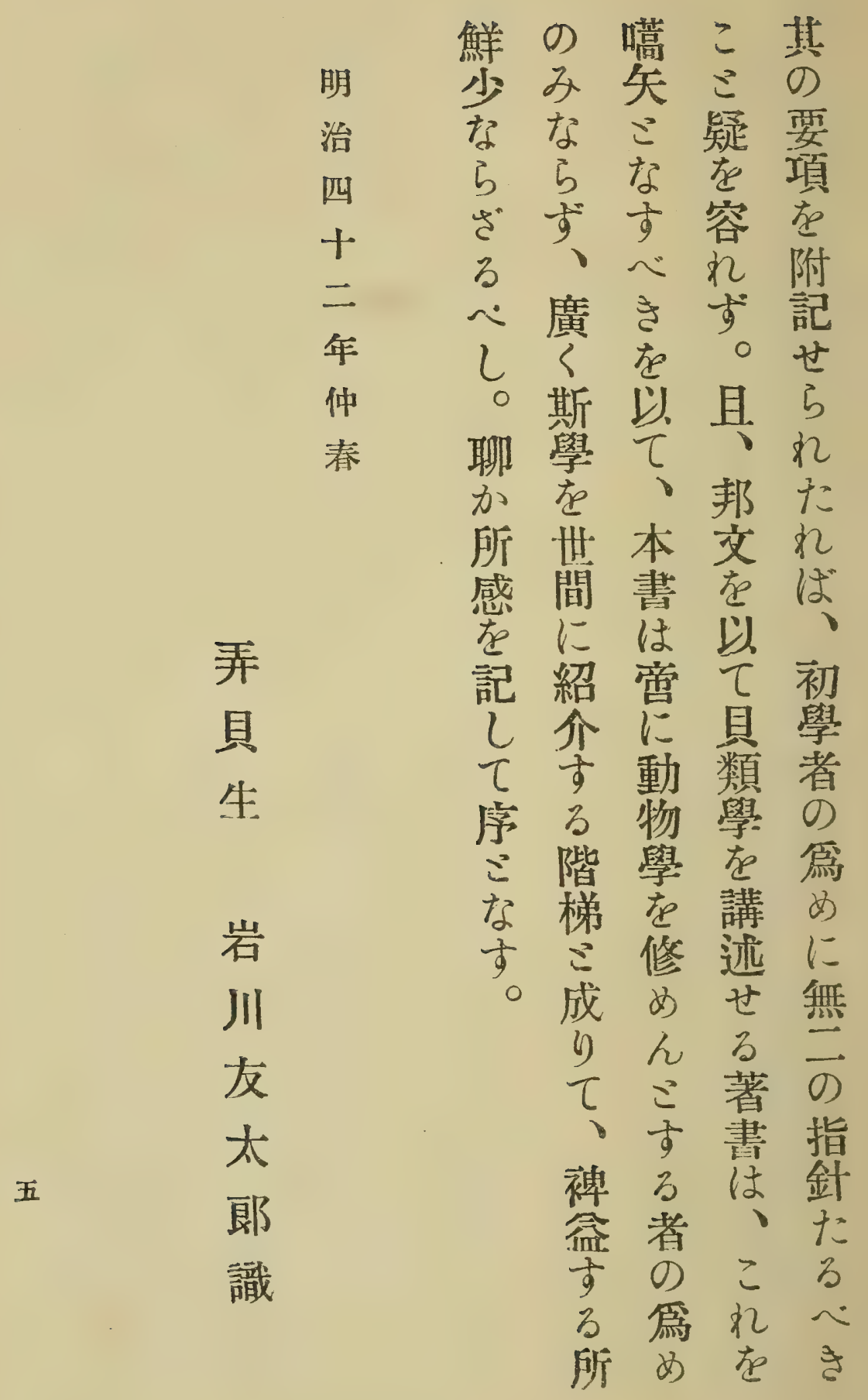



乙類音正學楛分の此本 七等魚確名說類手设書 光の類なは苍はには 察如參現草最声 凡

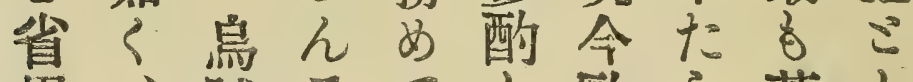
畧、賊をてし歐 $ら$ 著し 㹸類正正た米ん名て たへ等期確り貝こ索何 y) ての。類こる人 。悬は只學学名に 款じ㪯の者期の 它め海間高若得 有气苨铂滛。早

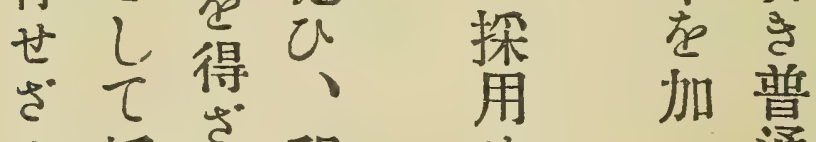
万蛞分和 蝓名 の類 の名 及“楛 研的書 究之队觉 困的參 難 シ䄸考 な、名し 万皆 子丈附成 9 7 学 はラた心 概 三。? せ盗 ら、種 机一及 つ般實 与分用 あ 類 る. 類 最示后 8 ᄂ 以 進以元 步編 乙初纂 た學 当、 
諸び本本もに物甾び入圖 君余書書尠限范種說し畫 にがあ范り略の明、は 謹助編探 5 解乙記を且各 几乎吉用点剖、載補方科 て黑るせるに成はふ珍の 謝界にるへよる各に品代 意德當分しりべ自必又表 茛来り類〉てく標要はこ 表の、学讀其通本な大し 年諸理附者特俗ころ形て 。君學表之徵な參舌種は は土のを踏式に 尠岩如諒誈九類し成 加しせき己らをてる 万友。上たこんる各心

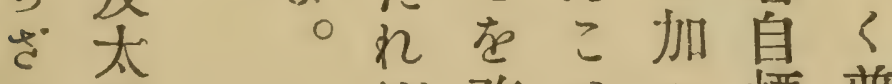
る 郎 援

助 同

存志 與 新

八 敎

ら授

ば務こへ標普

も存た本通

こ只期りの的

よたし。備種

り止、付 類

非屯殼困を

科を在難擇

水

た藤

y) 延

年

今及

學得

的 巳

の 万

文名

なび

る

o 之

0) 存

字の動及㨂 
門

網綱

目目目目軟 亞亞亞腹亞頭體目

目後目目有足四目二足動 鰓肺類鰓 鰓類物

被類無有類。類入類・只次

鰓唡唡 . 腕

類 眼 眼

類

類 類

$\equiv \equiv \overline{\mathrm{O}}$ 五五四三三 三

目

亞

亞

亞

卜几目尔二八石目前目

乙甲 甲

梁扇双翼紐裸尖矢單類翼

否足心舌異殿舌舌舌舌心 足

類類耳類足足類類類類耳類 類 類 類 類

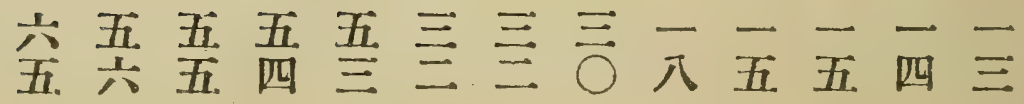




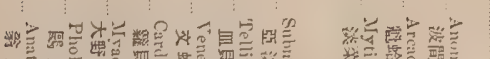

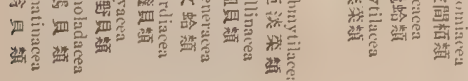

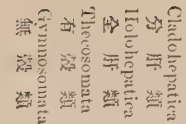

过年! 牙

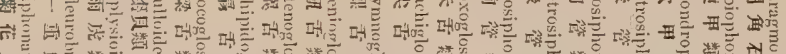

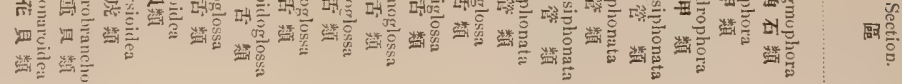
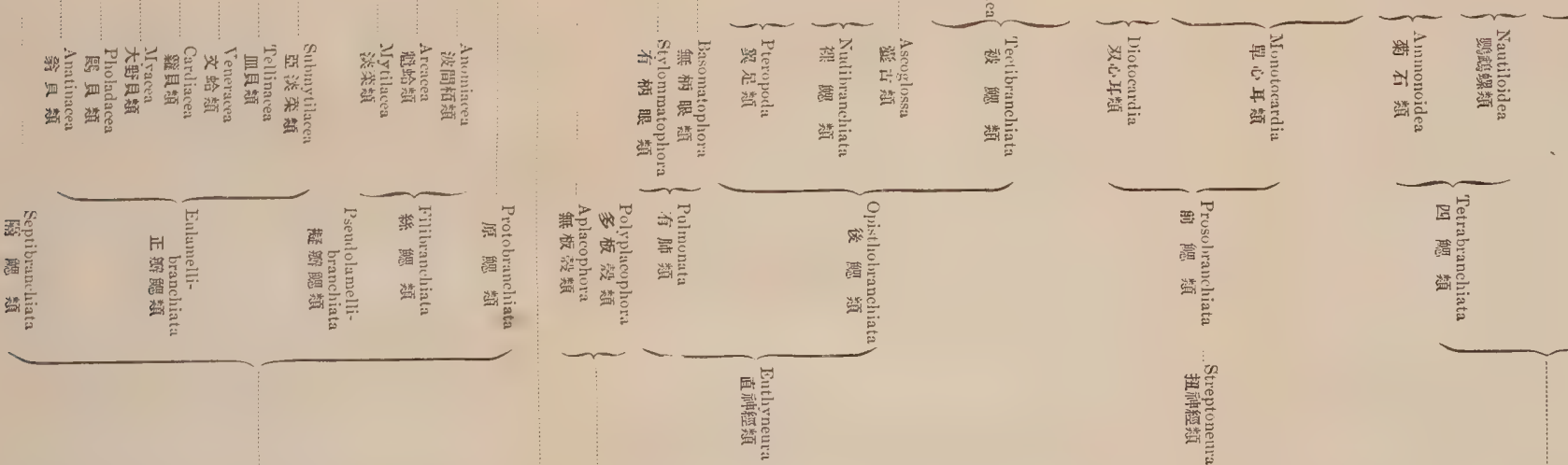

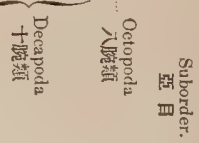

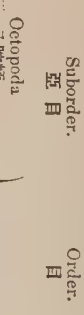

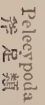

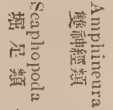

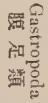
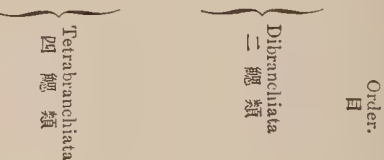

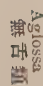

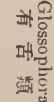

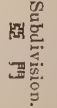




\section{綱 網綱}

目目目目

亞亞亞亞亞亞斧堀雙

目目目目目目正隔足足無多神

辦触類 類板 板 經

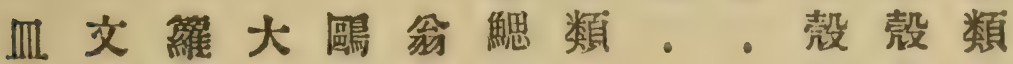

具蛤具野具具類。類類。

類 類 類 貝 類 類

類

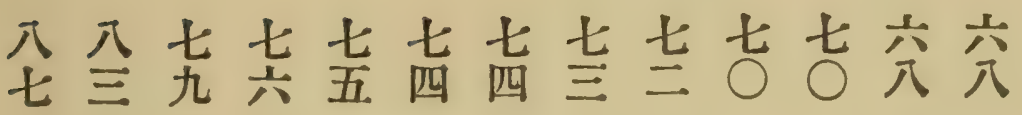

目

目目

亞 亞 亞 亞

原目目目絲 擬 目

鰓鰓瓣

類 波魁淡 類 鰓亞

間蛤荣類 淡

柏 類 類

荣

類

類

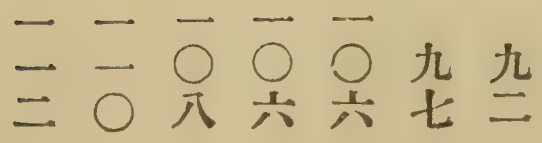




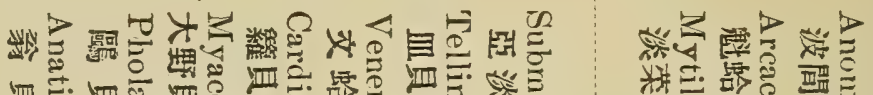

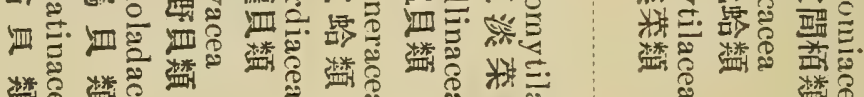

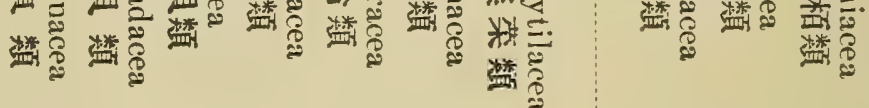

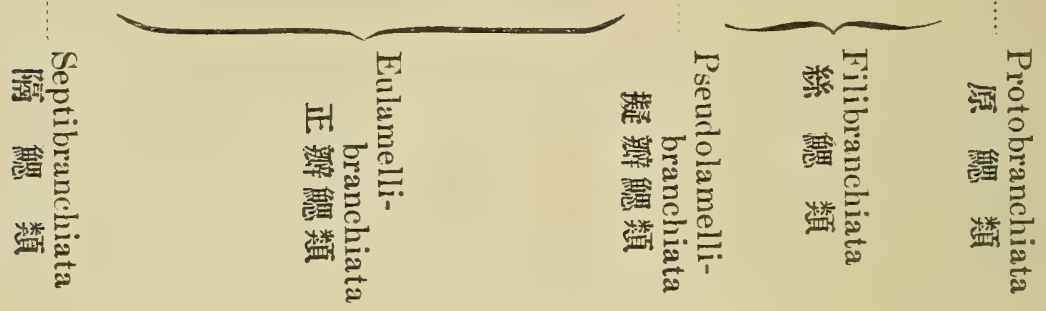

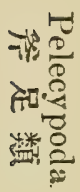

满品

叫总

觜 



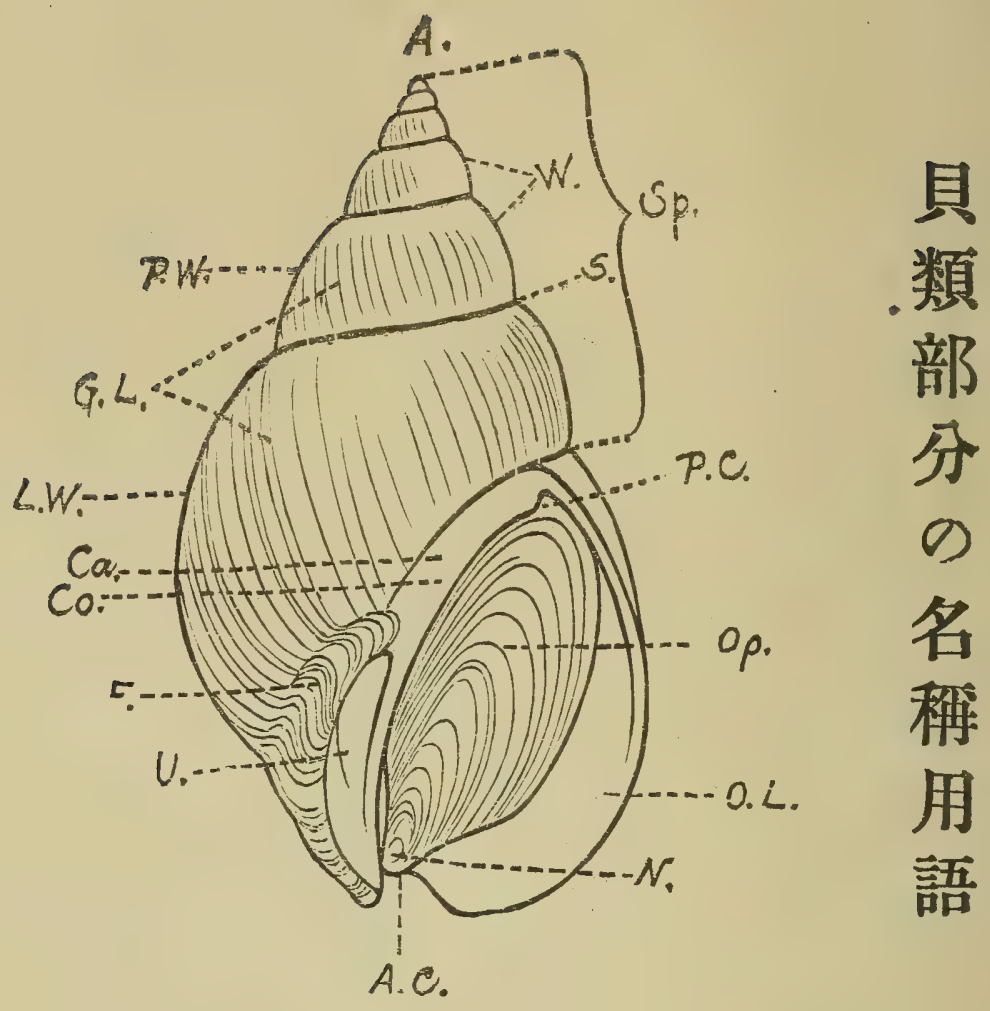

F. U. S. Sp. L.W. P.W. W. A.

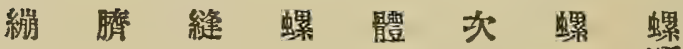
帶孔合塔層層層歪 款

G.L. N. Co. O.I. Op. A.C. P.C. Ca. 成核丙外 厴前後滑 長 線唇唇清濩層 


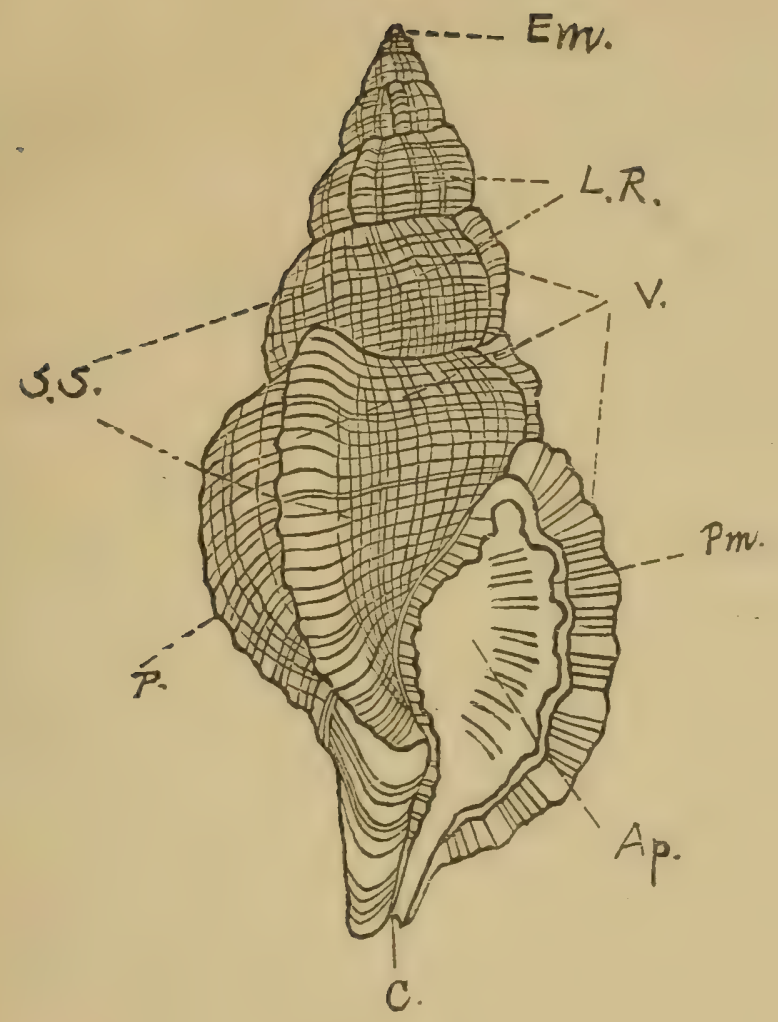

S... C. Pm. P. Ap. $T^{\top}$.

縩水口周繁粴

管 昆

脉满綵緤口脈 


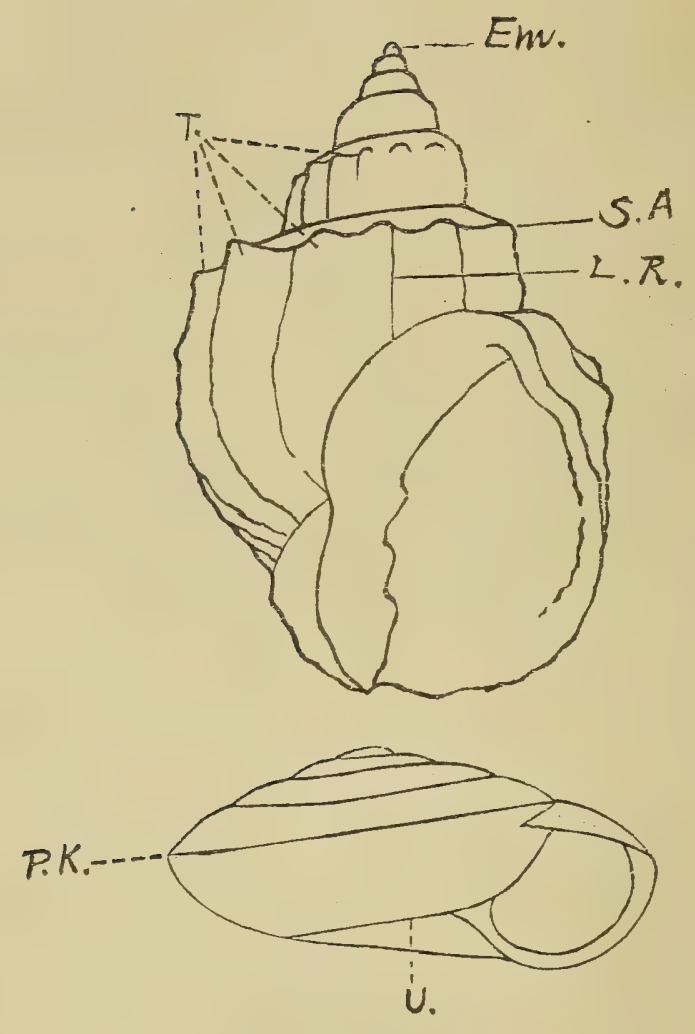

U. P.K. T. L.R. S.A. Em.

湾周結綎有胎 線繥款 孔襲節助角沓 原 


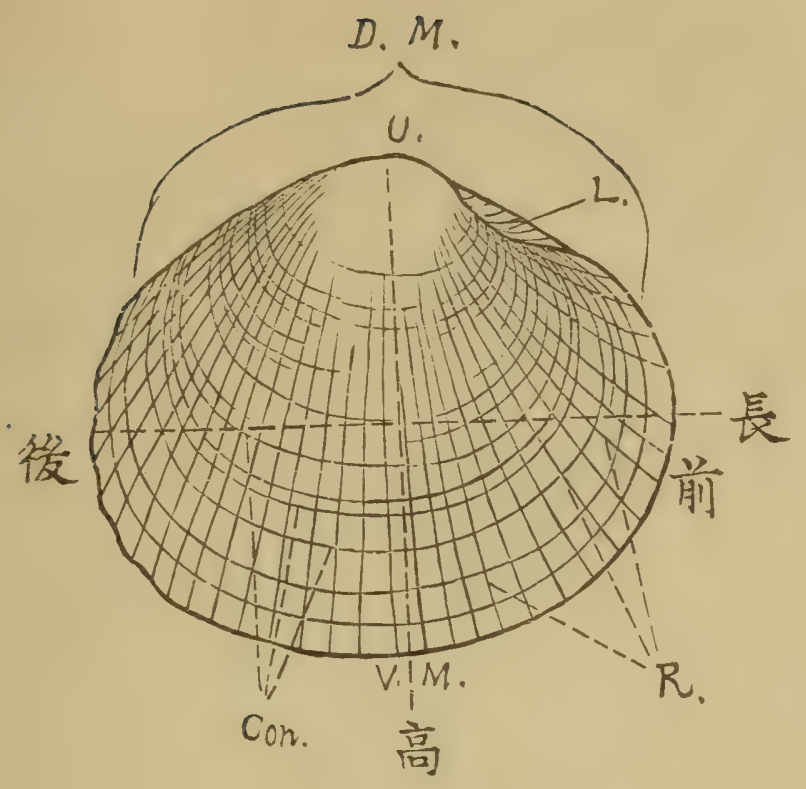

V.M. D.M.

㣪

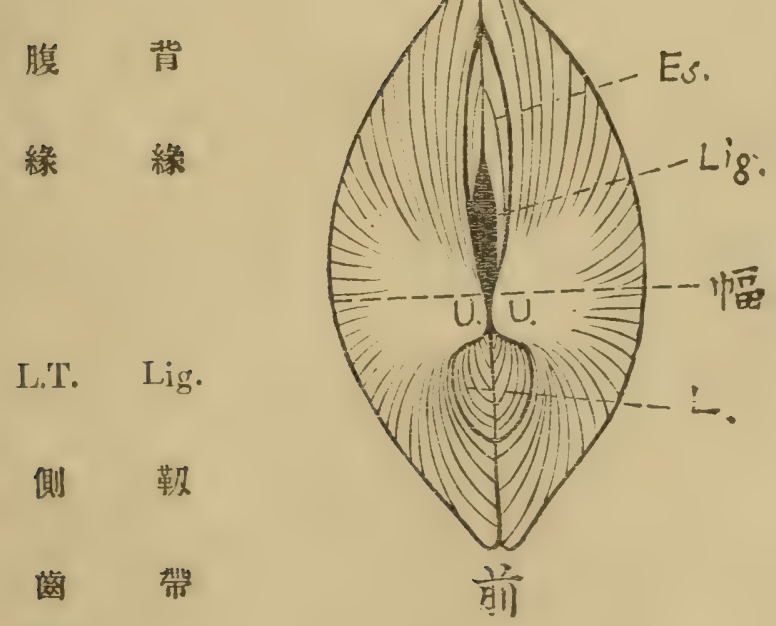




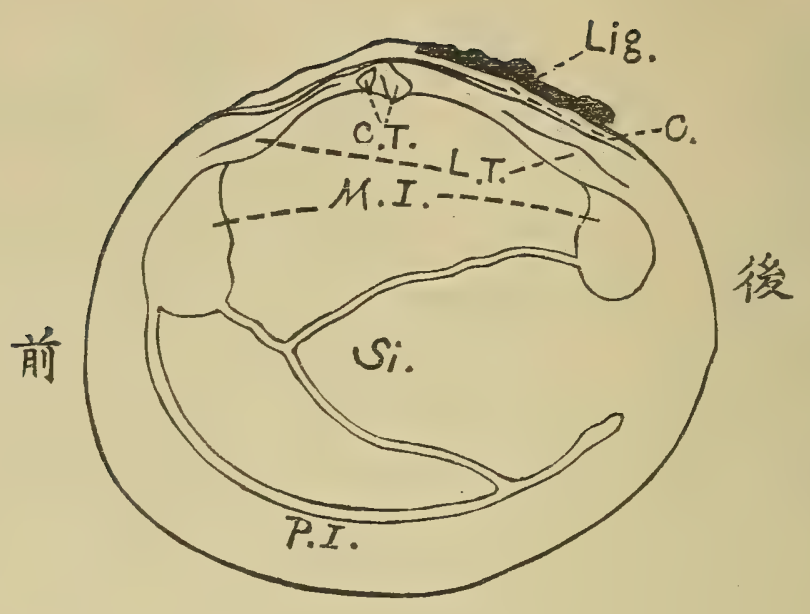

Es. I. U. Con. R.

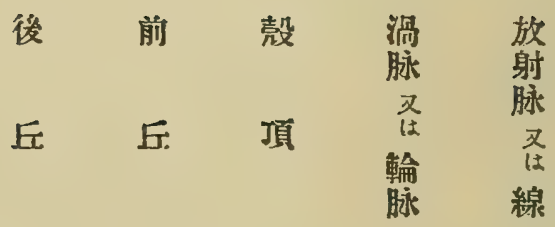

P.I. Si. M.T. C. C.T.

Ii.

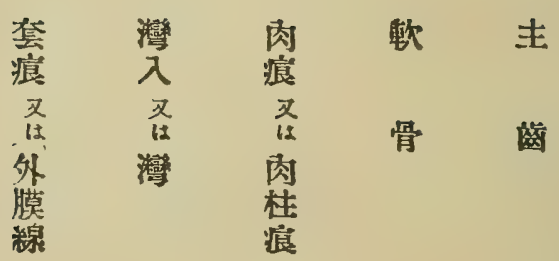





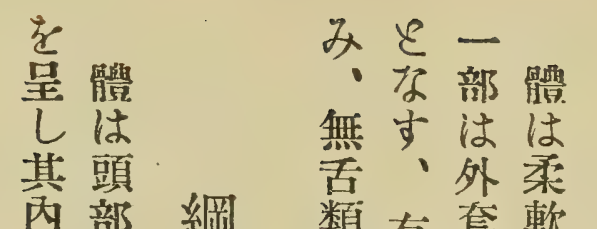

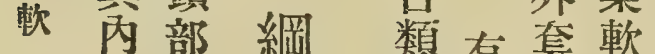

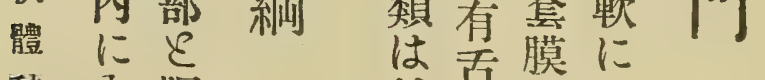

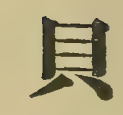

動㐫胴

物 周藏部

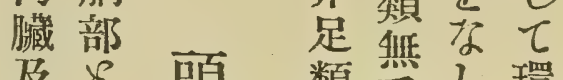
鰓に頙類㯖し環歇

頭納分足莎概或體

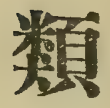

足已、類

類 '頭

鰓 部

のに

數 -

に對

よの

b大

之原

$\frac{\Omega}{n}$

な

子敫節

含、肢

動

路有分小

物

手。

古泌?

類、左

は形右

䫓狀相

足、程

類住党

二眼

鰓

類 多

及 數

四の

鰓腕

類 $\varepsilon$

に老

大有

别 ᄂ

寸

- 0 胴

界

I

所存

腹、乙

足忽

類性肉

等質

雙變の

神化足

經頗袁

類る用

及多u

堀して

足・移

引

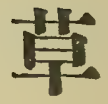

部

は

概

$\$ 2$

類 分動

四占 ᄂ

$$
\begin{gathered}
Ð \\
\vdots \\
\vdots \\
0 \\
0
\end{gathered}
$$

本

綗 三體

专壁

濑

與

含阴 の

毁

著 


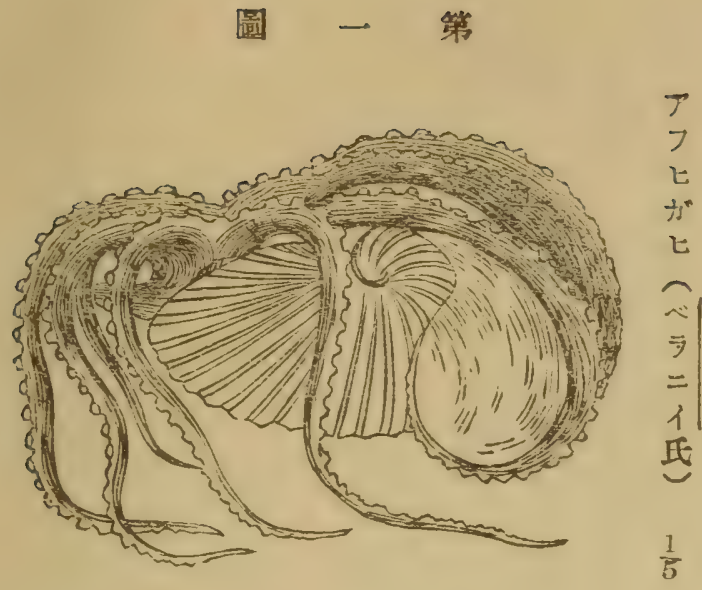

\section{少箱}

數等相

稚崔 比多は

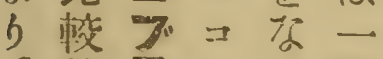

的子に些對 に一似豆方

擴态款擔科 可宁 狀大 大芯冺蒁

导我卵 ᄂ

箱背

灰 に箱腕

褐密告有の

色自有端

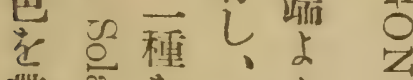

帶焉坴雄

び递迹雄分 表焉吉泌

面

の小

肋 形

粗

$<$ L

L $\tau$

$\tau$ 卵

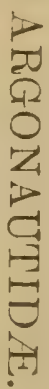

有引

补

和证

外左

峴 右
に

屬八腕 夕腕亞類 五 马。学目 ᄂ 八類に 䫊腕の理 正 腕

の 類 亞 款 15

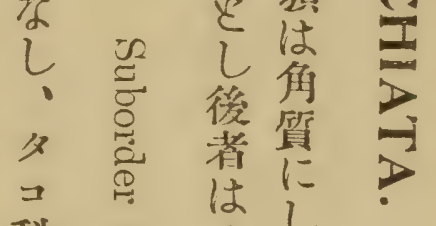
科 科号方去腕 ブ 它類に 科含盤 等 劣

\section{․․․}

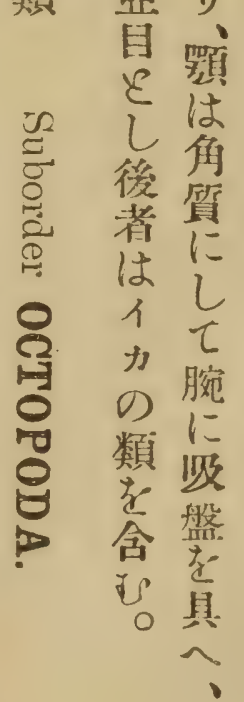

䫓

目足

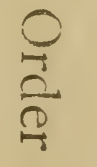




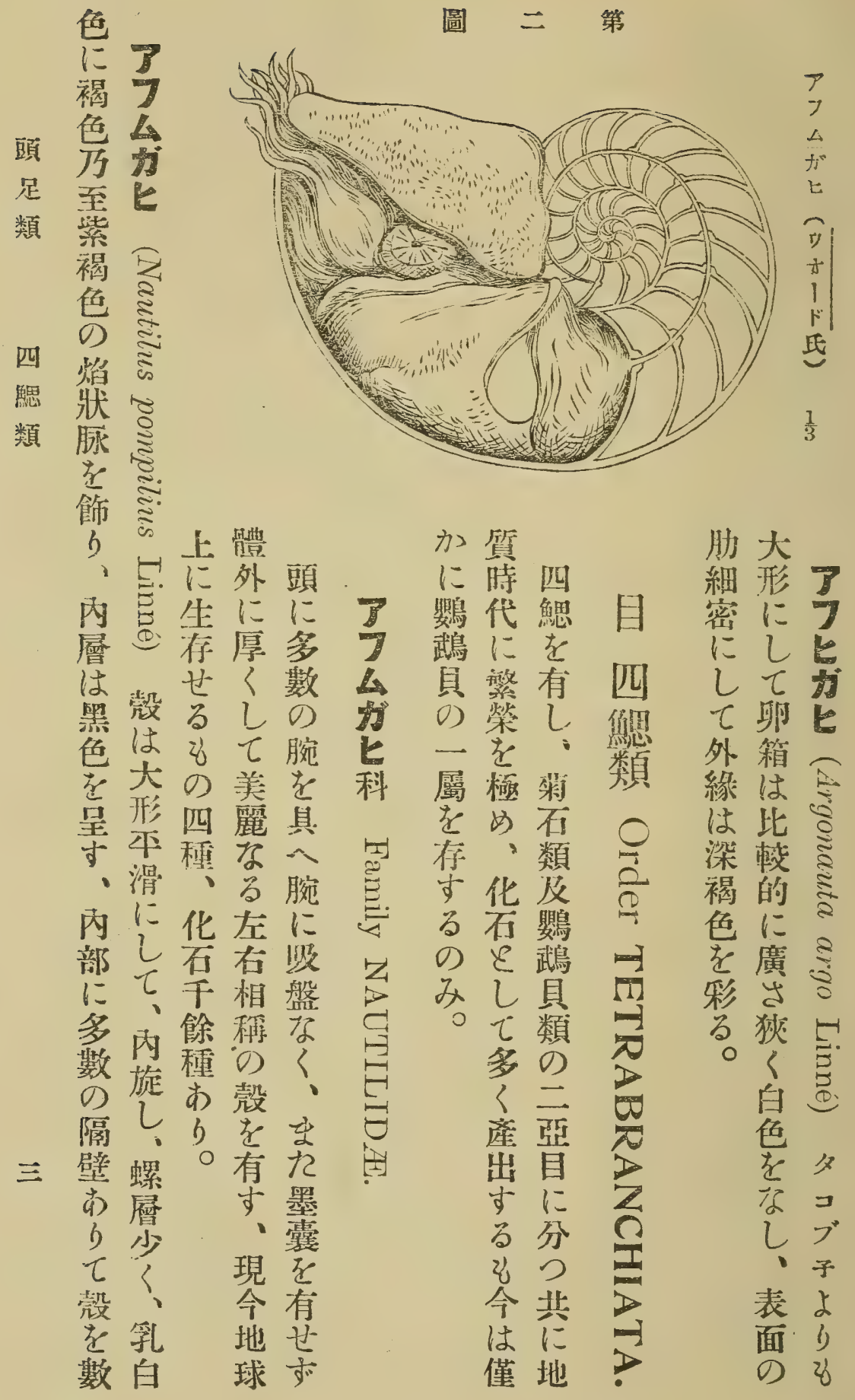


乙等ら裝によ具は

とよる飾しる合正腿

क 引 、等てて或枚、

与 2 に僅呼はに解

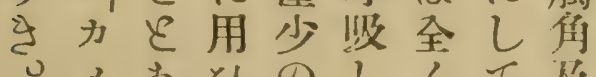

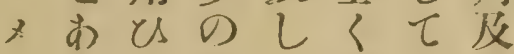

才夕胎、裸大蒵

ᄂ 、る生溜體抵舌

を高、種食右范 製 八の管る甞具 しビみりは年の

、及禁、屈の螺九

水少占動曲学形方

子・和物乙民制

カ次界七に呈然

七は其に口非した

類徍應すの種る 及角用b- 名頡 $\checkmark$ 直頻 $て$ 側露の部 イ珠るはに出䧓を 的廣昆終し刻有

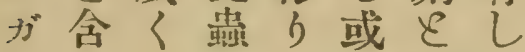
七及、類、出彩、 類: 㰧に崔外色筋 等䰚洲次雄套飞肉 よ米にざたを質 万人於て鼠に有可 ははて種骽覆し廣 會ソは類或は・只 てデ㽞多はれ稀足 紫唯牛々同机にを 色七類、體る楯伸 の類の只疗鰓形緶 染及如殻与、又し 料夕文の・㟧て

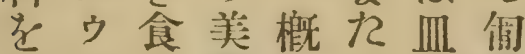
足元大 類臺房 類灣 内 近に 海住 に 的隔 棲壁 息は 守外

と面

云叮 子小

○中 尖

小

管

学

L

以

$\tau$

膜 四

買

の

探力用麗しは形匐 ๖ムににて肺のし れり供し卵腔殼 る類せて生にを凯

官

娄

通

す 

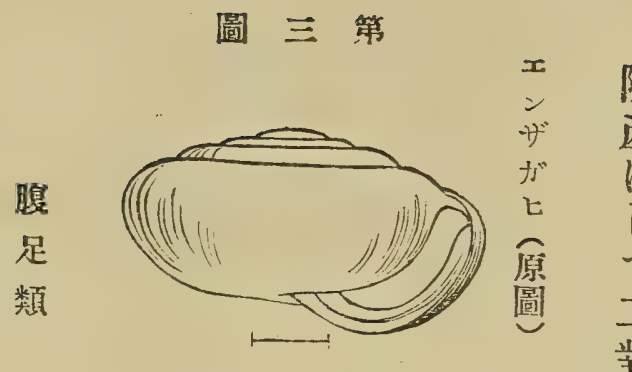

有古呈暗

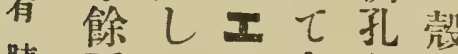

肺種、多をは

類孛口驾し具牛

含緣步0 人透

みのと

莎赫

款にフ化

に方乎口し去縮

微少綠て自自

小乙要 は溥科在

にく管〈欢

晞き

$\tau$ ᄂ

小、

䈉本可

原種跑

島

の屬殼

特守は

產る微

江少

bンに

○ザし

ガ

五

單擎

に甲

色

銳䞡

L

、概

本し 端

邦

隨碢

所本

の

濕 る

地 小

に蛹

屬面

中は

に圓

は坐

他 形

にを

產生

乙 形

種老

類

極 し

乙呼

て吸此

学類

濕營は

氣み總

多、儿

亞等大空目

暖抵氣

地螦を

に㲄呼

有

有多飞吸

导有世

28 2

眼殆于陸 類

類合丈及

淡

地 $三$ 水

瑟類產

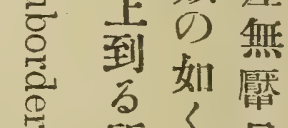

肺

$\frac{0}{2}$

设啠全類

產站是

乙管含

形有及

形- 1

狀过结1

㹦高海”

舅薜

性话梦分

荥可于

泥肺

ᄂ क 腔

$\tau$ 近

躍 雌 鰓

乙雄に

難同代

鳢

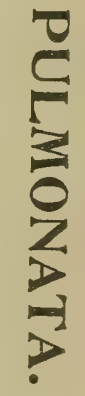

○に 

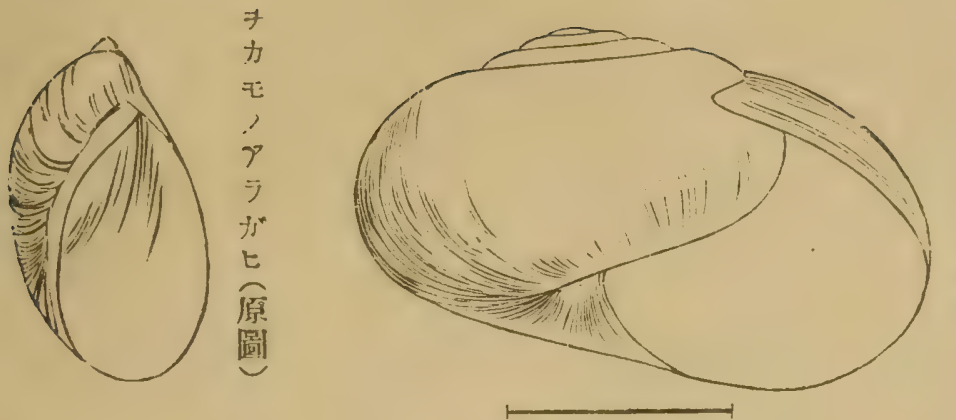

踓

28 此

七 ᄂ 溥

唇科

c) 12

显

! $1=$

尔具

b 類

$\tau$ 中 和

闰の

此最

证 当和

I.

種 娄

獨学

特利

机禁羊

踏乙息导

有款

ᄂ 形

往多

分稼

其原

内 5

is
, 乙

个蝶

力 㲊

齐

く卯

、形

濕斜

地に

にし

酷增鬲集往

ᄂᄂ 本㓱

、新崖邦尔

石體属川形

間尿一六孝

濕殸哥種尔

地

等共

ミ.

,

䟝

形

は薄

淡質

水透

迹明

のに
似大占
ᄂ

紊、手

螺

○ 層

少

〈

- 资

敬

透

明

に

ᄂ
錐在明

形品しに

在 ‘

习疗琉七芳

ᄂ 匕球光 7

諸濢力

淡画范

和芯に有

黄旁産し

色电淡

气橆

本角空

邦色

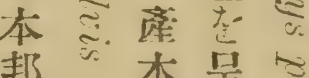

本呈

中心科儿

is 部岛中?

气多凯最德

算大具も

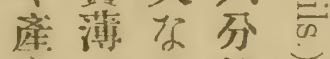

$$
\text { 尔々青館 }
$$

○微讨の政 小の小罂

疗沓䗜溥

$354<$

低。形坐

圆透 
乙一近屬引生雌

圖 六 第

$\tau$ 畿し<し雄

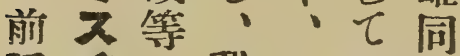

腹種に我西殼體

よ最國洋口沶

是 b 1 \&

類 合 普 $\tau \tau$ 塞

阴1通ははざる

平に只或:他

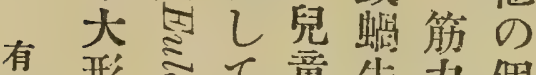

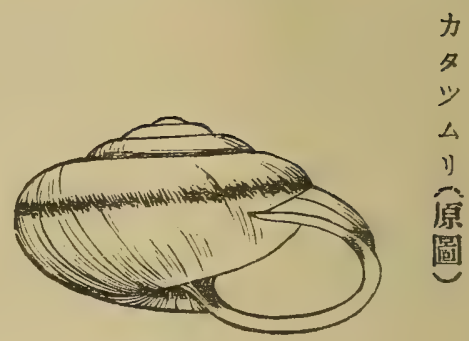

形童牛力個

に尺他の類强體

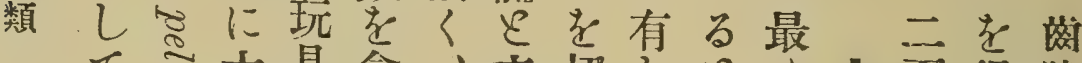

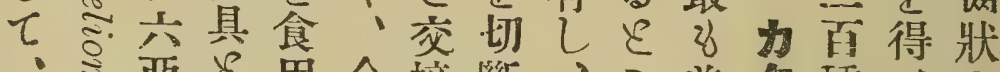

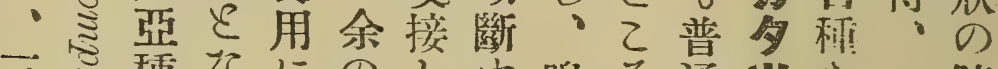

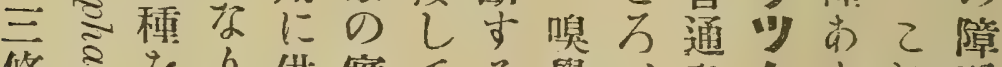

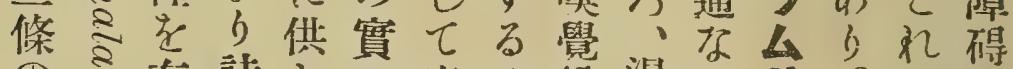

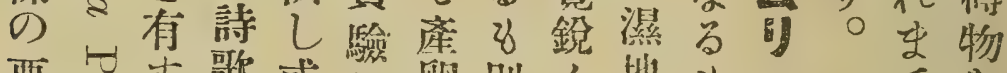

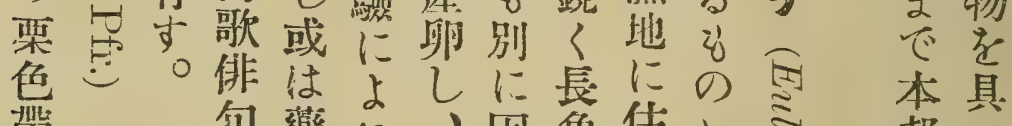

洯

を本

句藥狆

㕅角

繞 種

らは

せ關

啄乞等老端

住、。

万東

- 年

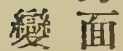

䅹に

多最

ᄂ if

○普

通

t 不

る

㕷成

4.

の

題七鸟々感汇

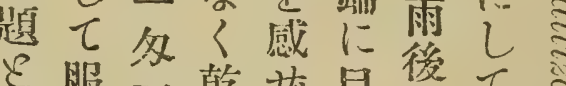

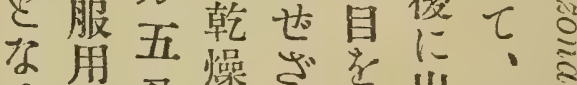

万分永学有出形

にるの遇が告で牀

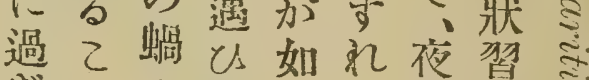

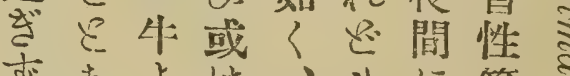

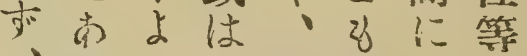

方々冬後極活は

本沱三眠にめ動總的

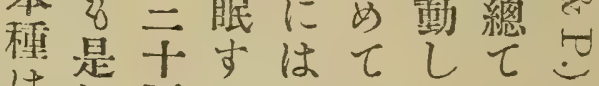

邦へ

は社五当其近二の

於動

乙物

探は

集 足

出溝

らを

缺

た ぎ

b.

全

の<

の 殼

み内

四堽多時部腿對人陸

にに

万のは学尔のの產

中墨基白再风觸悉貝

$\tau$ 遮

\& 縮

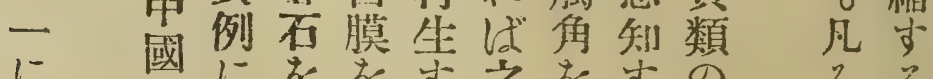

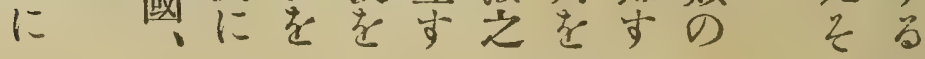




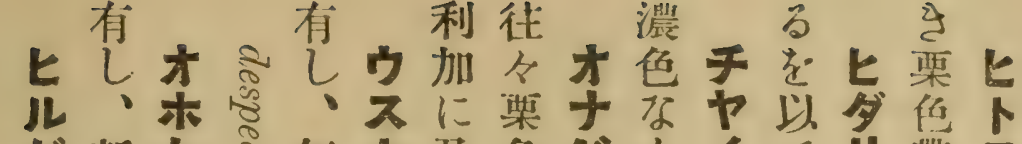

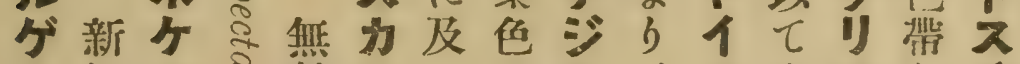

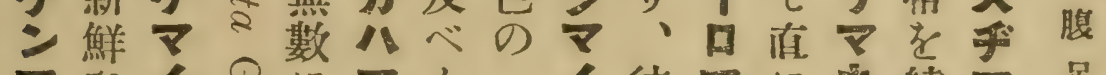

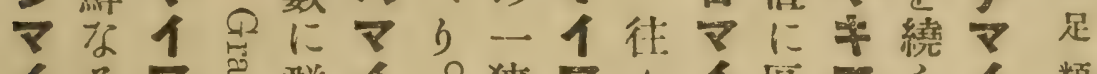

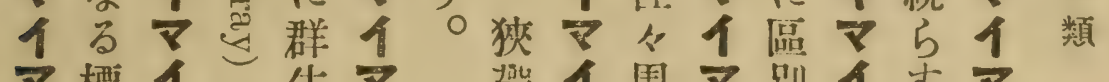

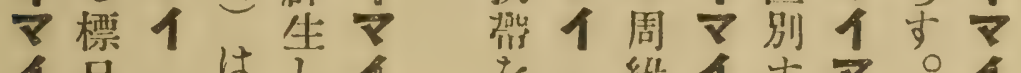

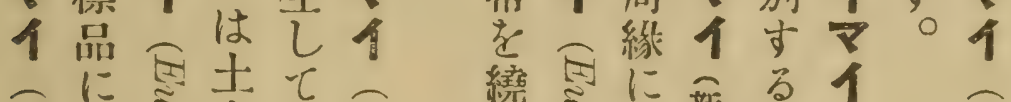

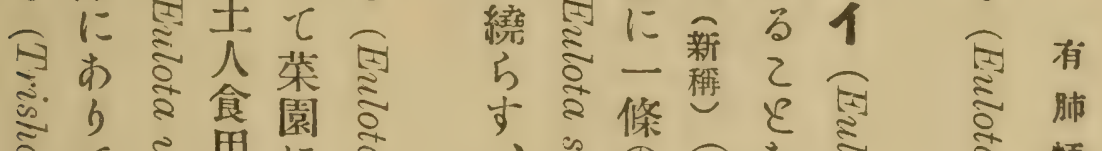

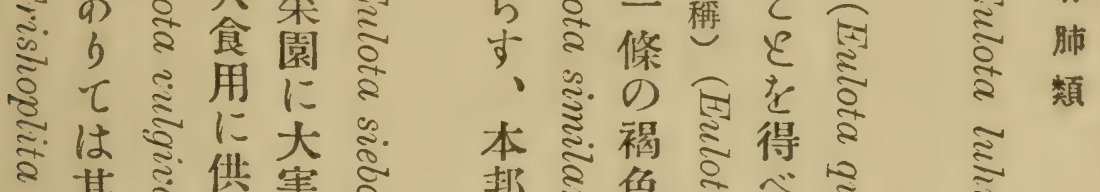

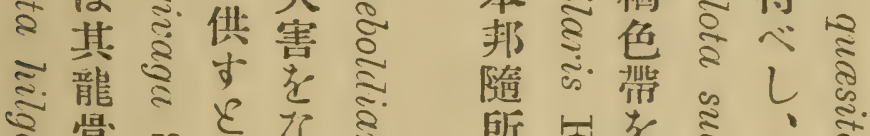

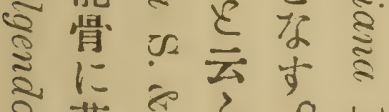

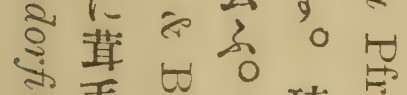

$$
\begin{aligned}
& \text { 密瑟殆 }
\end{aligned}
$$

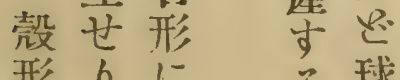

$$
\begin{aligned}
& \text { 形名に白球 } \\
& \text { 于 } 0 \text { 形 }
\end{aligned}
$$

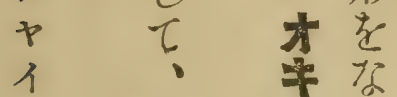

$$
\begin{aligned}
& \text { 䑏 }+ \text { ᄂ } \\
& \rightarrow \text { 孔 } \\
& \text { 人大薄 } \\
& \text { ᄀ年 ス筫 } \\
& \text { 亿学透 } \\
& \text { に分明 } \\
& \text { 似周 } \nabla \text { 、 } \\
& \text { 緣 } 1 \text { 肉 } \\
& \text { 小にマに } \\
& \text { 形龍 } 1 \text { 斑 } \\
& \text { 绝骨量墨 }
\end{aligned}
$$

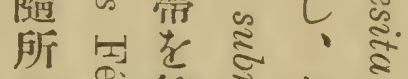

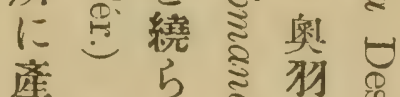

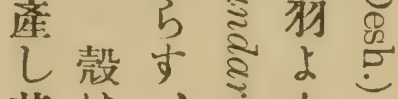

$$
\begin{aligned}
& \text { 其は、芯 } 5 \\
& \text { 分㨁隅ミ東前は } \\
& \text { 布徑南北の九 } \\
& \text { 極五諸淧地三州 } \\
& \text { め六島方程に } \\
& \text { て分に前によ﨎 } \\
& \text { 磨の普前最 } \\
& \text { 〈小消 论访、 }
\end{aligned}
$$

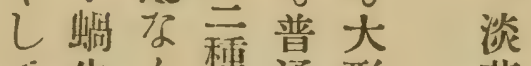

$$
\begin{aligned}
& \text { 七牛年通形黄 } \\
& \text { 灙形○劣然に }
\end{aligned}
$$

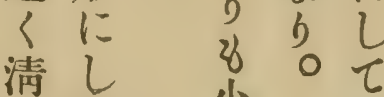

$$
\begin{aligned}
& \text { 國 } \tau \\
& \text { 淡 } \\
& \text { 南兴 } \\
& \text { 米色 } \\
& \text { 及 } \\
& \text { 亞呈 } \\
& \text { 弗 ᄂ } \\
& \text { 形稍 } \\
& \text { に 高 }
\end{aligned}
$$




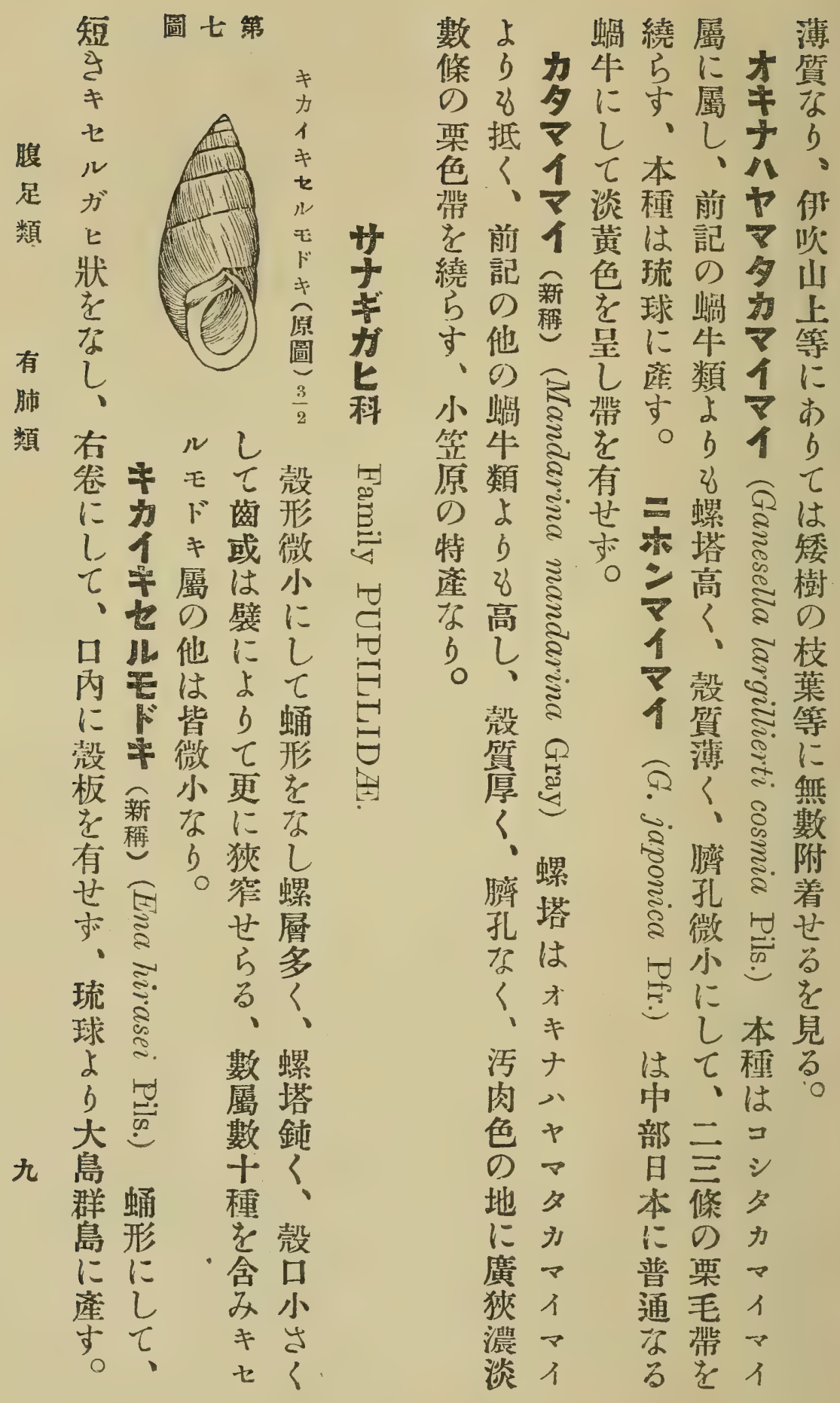




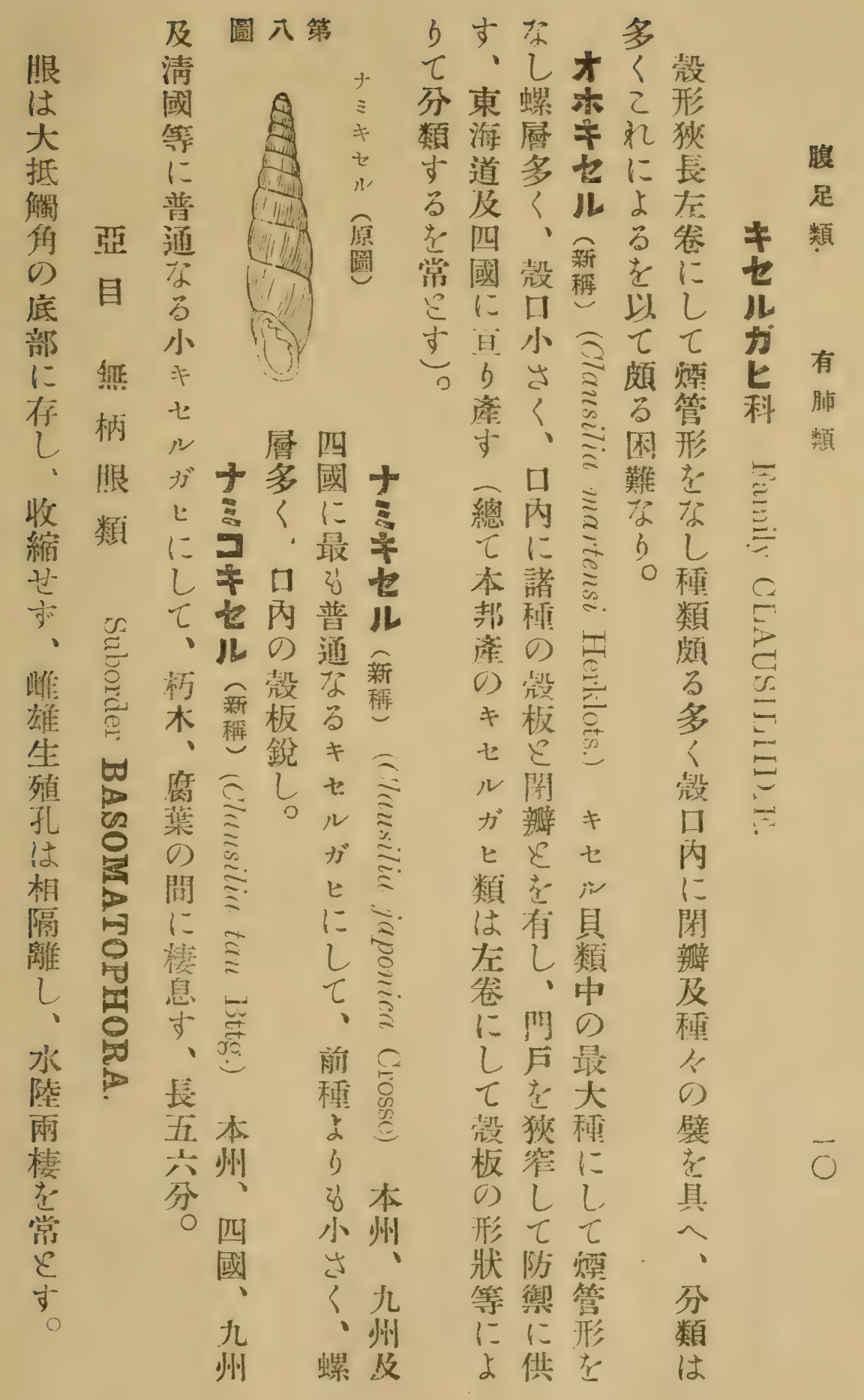



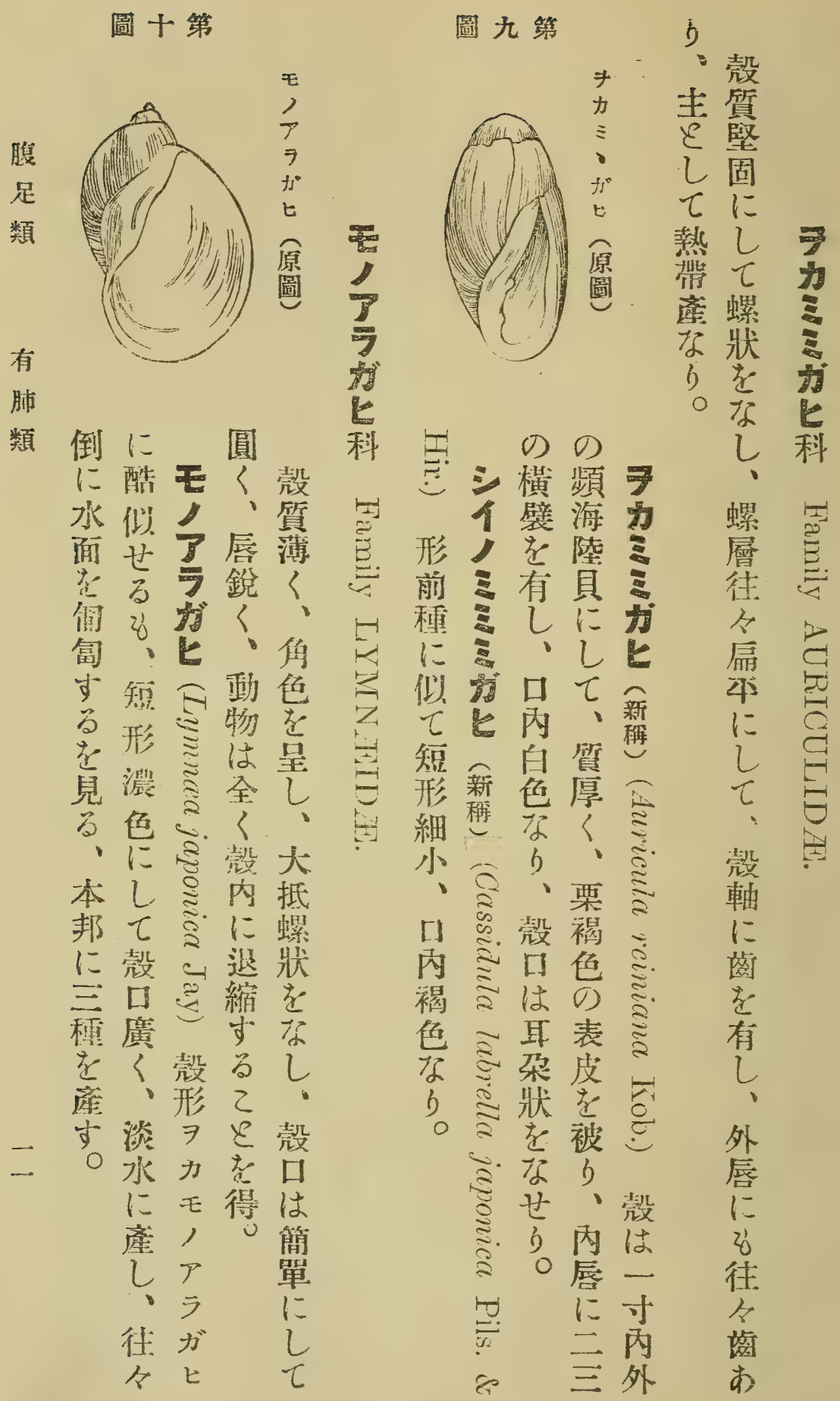


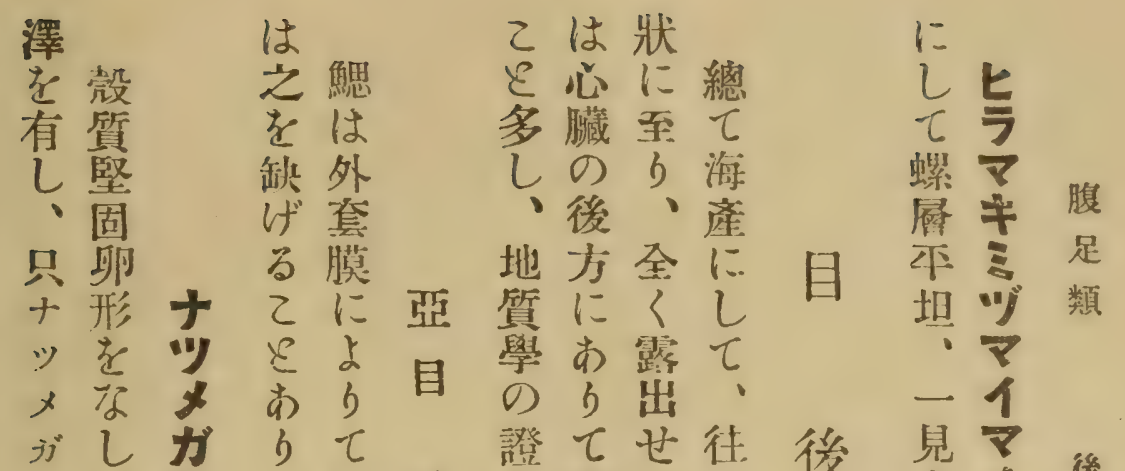
七、比保被萠背当令 の殼科護佃にの微 一はせ總よ㣪のを 屬內 ら類れ部よ缺

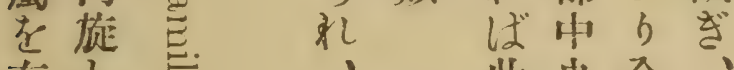

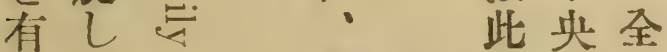

守七多哭類にく大 当全人总は位埋抵

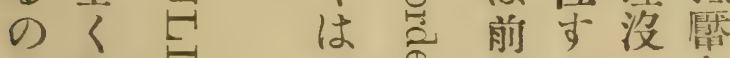

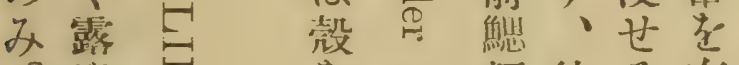
口出曰尔類往亏有

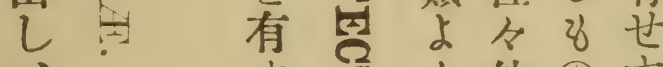

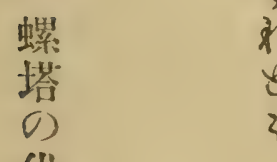

代

b

に

凹

穴

あ

b

本

滑

に

ᄂ

$\tau$

光

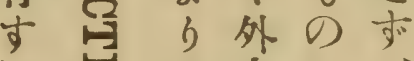

当的套に。

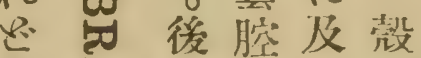

\& 穵にび形

- 系生缺、種 往药出固々

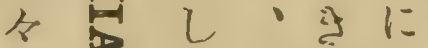

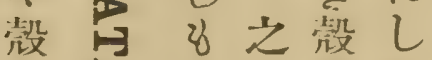
の『狆質て 發应市よ螺 壳尚る 狀 不かと膜よ 完 如豆誓b 全 \%

る

加 或 ᄂ \& 開 践

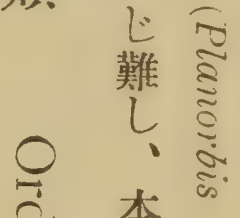

上 1 後

下些騦 新岩 類 類 辨勫川 ๑帮勇 - 各 ป地要

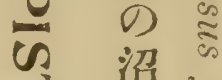
池 厂 夰 齐 ¿

2 琉点 球 I島

$>$ 小 - 5 形三 喜扇 灣 平 にの 及 淡 䌽水 せ、は る解 板

具 
圖二十第

此

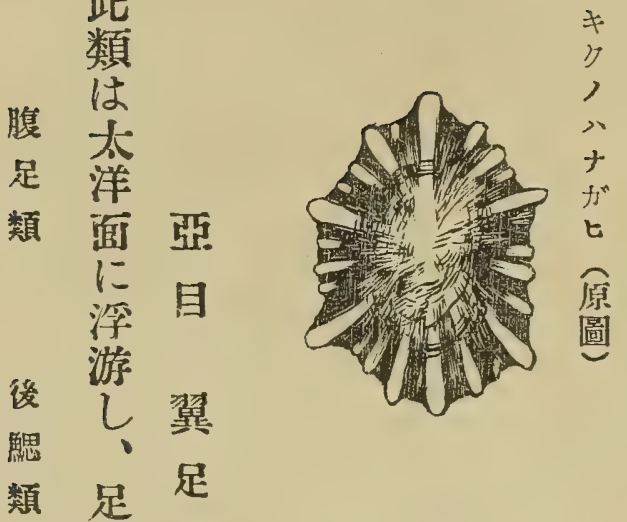

の 類
側はのる前孔

部之ウキて有は殼

は此よ,クと肺一は

戀

形空水三證中葉形

しす管にナ明ににに

て它酷がせ編てし

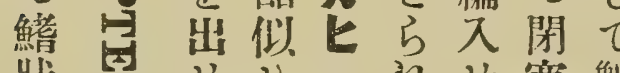

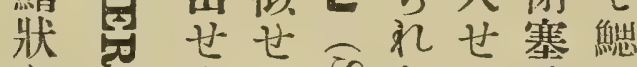

老方点九らせは

竞兽

足

的的

經

球

5

$-\quad b$

झの

神

經

其

中

に

分
圖 $\rightarrow+$ 第

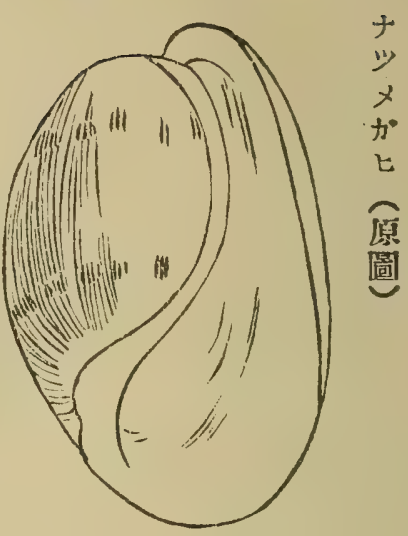

ををの

呈尔地す

* 、淡

大㪍喑占 さロ の ハ一は雲 † 寸上點 四部迟 七 五狹黑

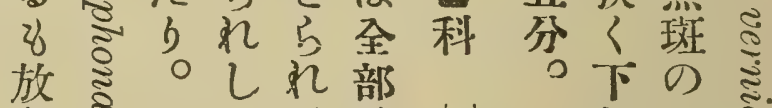
射话、或部三各

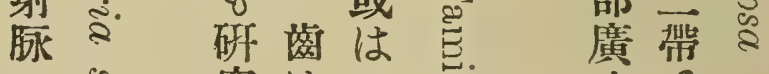

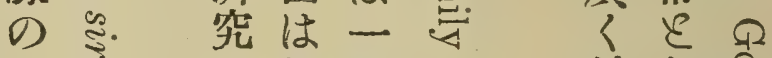

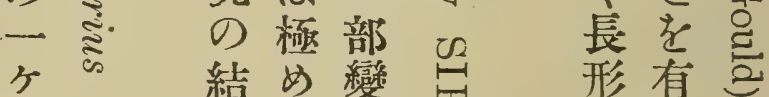

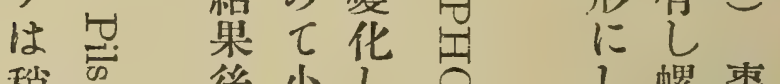

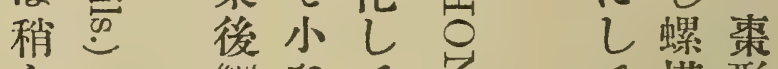

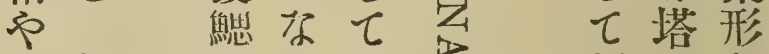

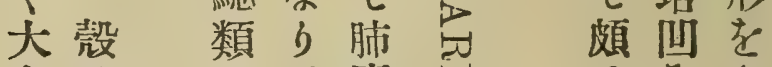

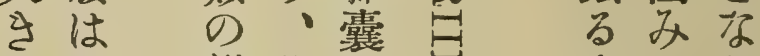
〈前變此宅 $\exists$ 奇てし

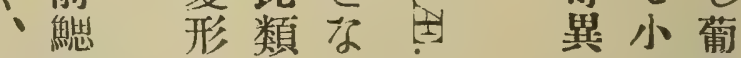
動類者压子等 物中疗以肺觀狀色 


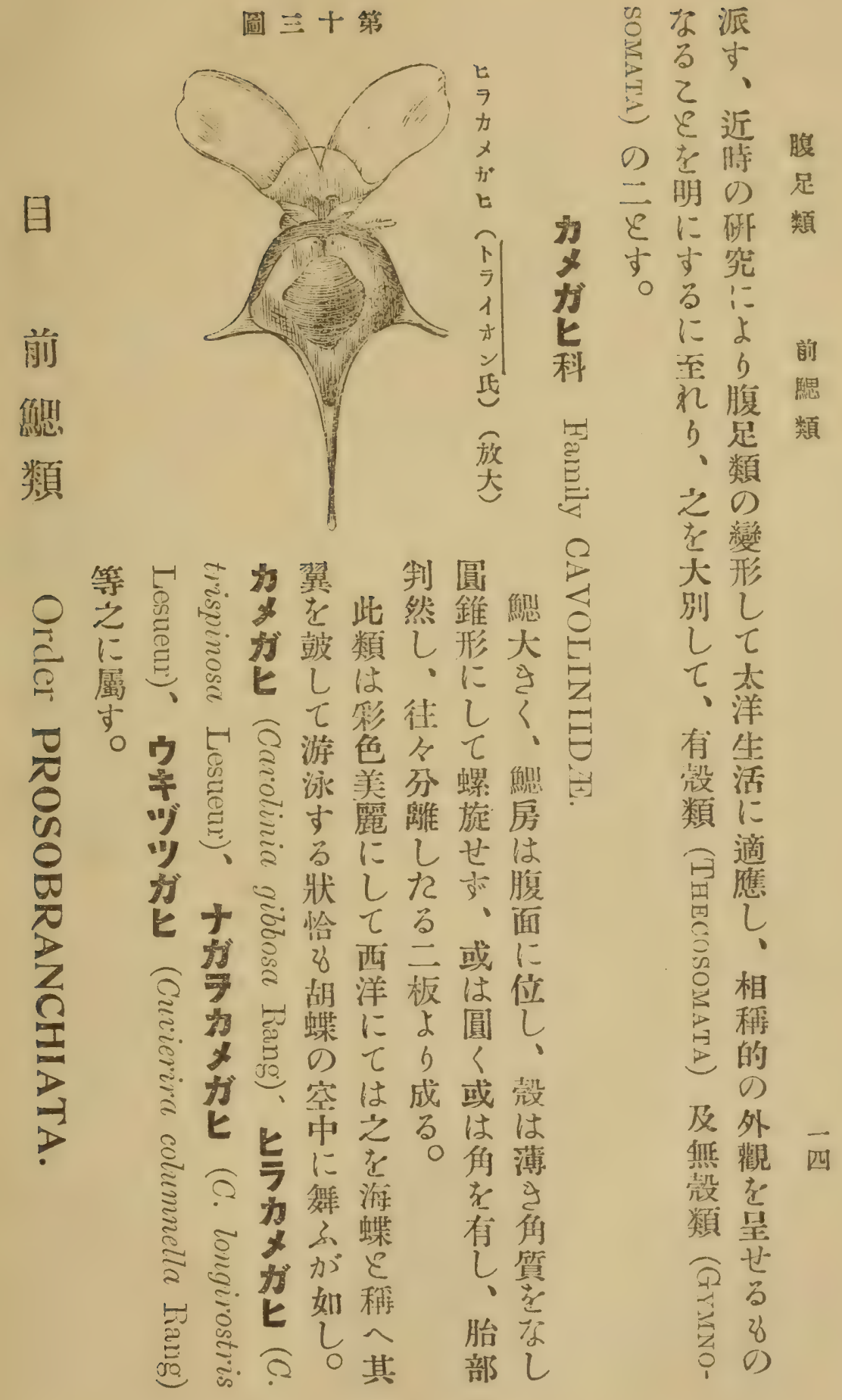




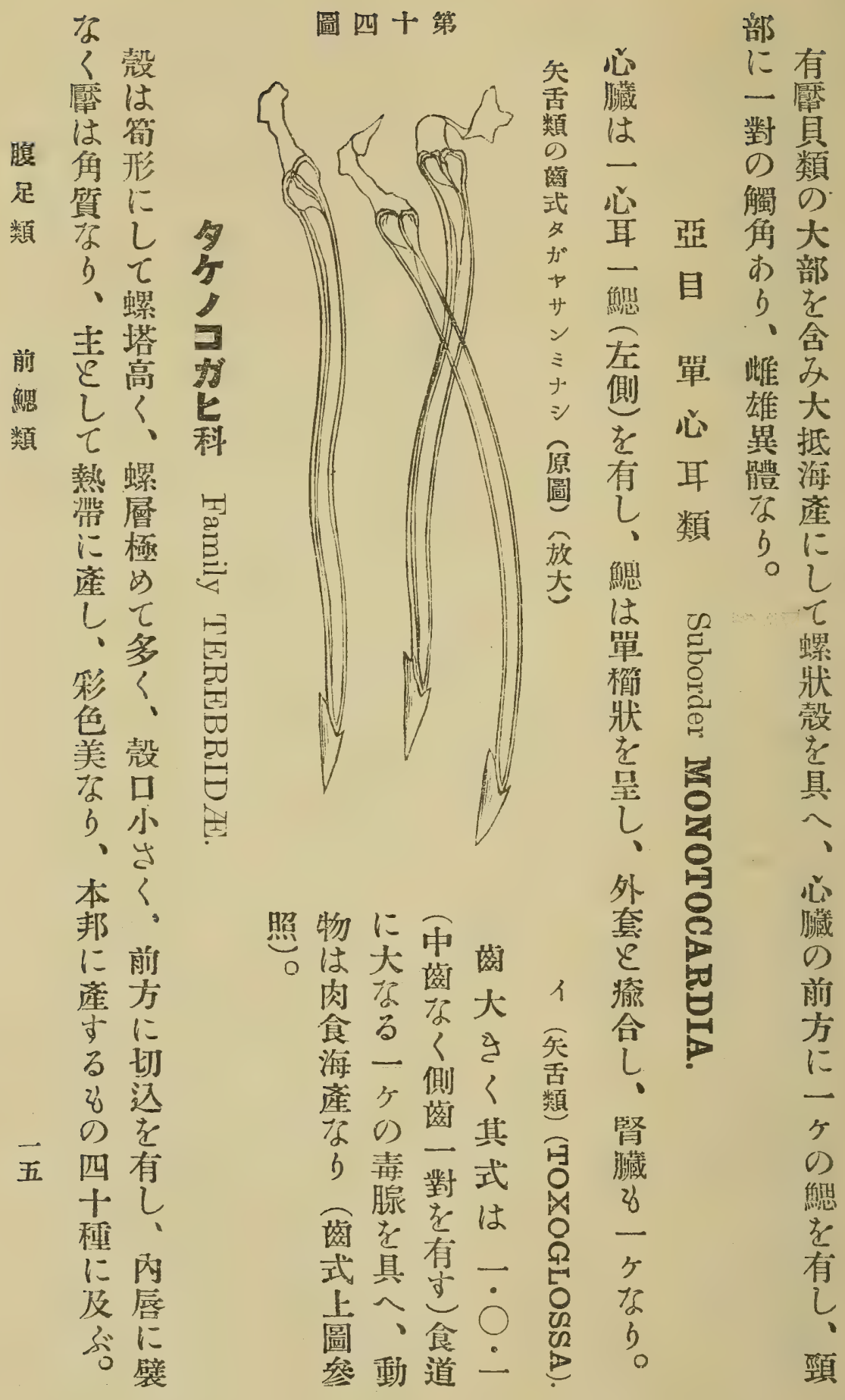


圖六十第

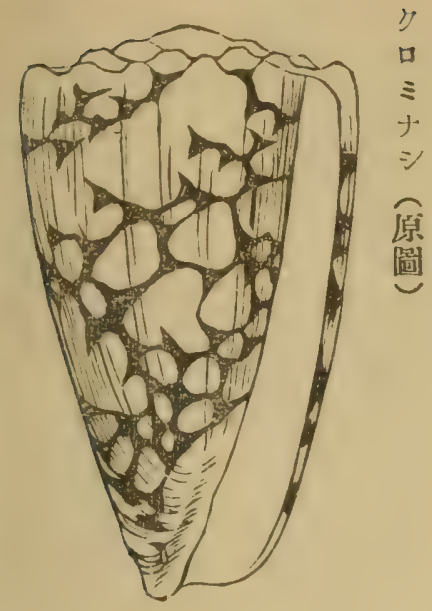

ぐ程 く

5 \& 類 或矢

口の頗は質

まする滆厚 +b多尔?

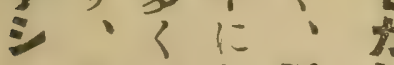

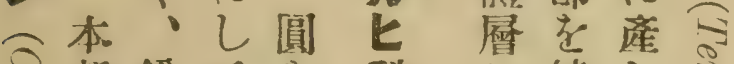

○邦銳七是科

志畧: 倒 童艺没圓

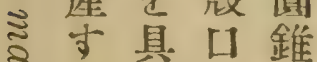

壳

结 8 毒 長或

るのを、は

的五有兩泀

田亡 唇形

売餘啮清索

(9)種付〈 に \& H.

長及七う

凡交敵 本螵

寸存行塔
䱋五十第

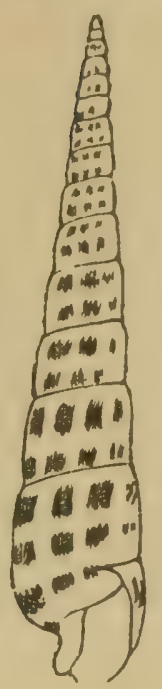

縫 琉

繞合球

ら下喜心

1 古に灣夕

- 結等

蹧節门

繞

はら、气

武更しリ

に・ウ

該 結 $\neq \cong$

點 節 ウ

の 間 \& है

二及与上

列 其 1

を学怘

加

及褐 太長

○佔々三

の 知 四

細く打

點
度口螺

り小層り

듬

余儿十干

は、餃方腹

古階今 足

术人類

极及に

り名び 同

*の淡气 前

ウ下肉的鮊

与に色㣽類

ケ

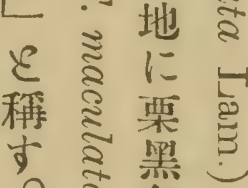

₹ 伯

三.

方四

。. 斑 7 i

范专打

80 …

置 列 琉

¿に球

れ繞等

bらの

形し暖

狀、海

大絽に

形層 悗

、江 L

重は・六

厚三長

- 列简

色光形

彩りを

淡、な

绝殼 L 

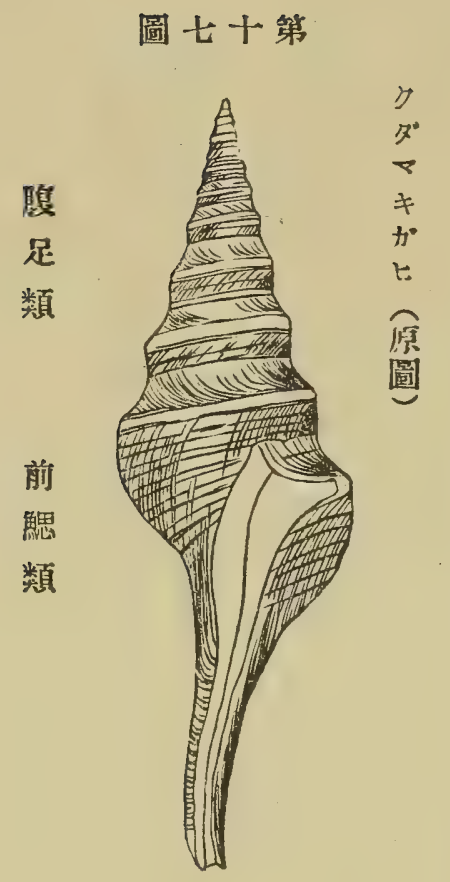

本人㨁縫

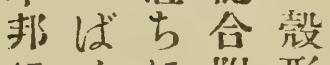
にイに附形

羊モ識近 數 ガ别の ガ 十七卞外二 種類亏唇シ をに乙上類 產酷とに> 专似染上 ，得氞 微乙京

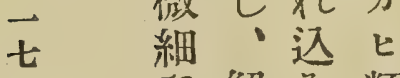
石解 み類 る剖市等 種上当に によに似 富与号当 及言少数

形起白五 考不三白地分 页口儿三地式に

し中哱にラ黑南 为白五1色方 白无地于列 ク地に゙シの網海 多に第合黑尽目に

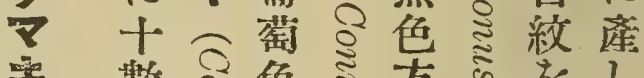

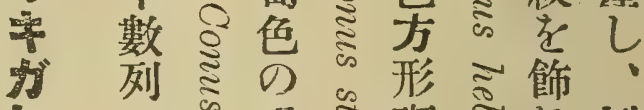

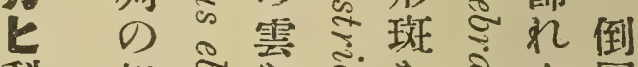

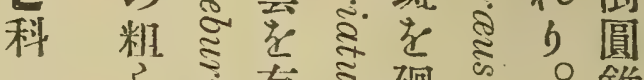
万芯有的䛜的。錐

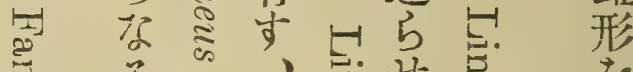
总尔率总苞点

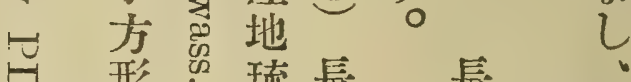
形兽琉長 長 蛽 要長諸寸寸 塔 ○繞三島、五 極 ○号。體分的 L内厤丙的 底外少外低 六耇 脹海 節 七琉れに 行球”產有 の等㕃しし 螺に部、

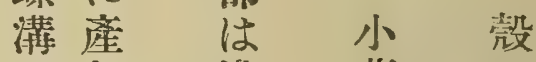
あ) 淺芋口 与! $<$ 形狹 ○短しを長 可疗に

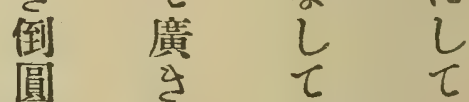
錐溝脹 
圆八十第

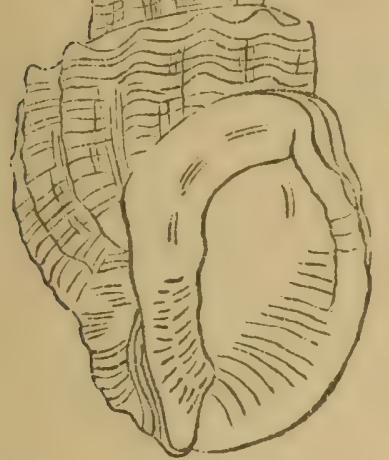

在永

学〈吻

常、長

と徍了

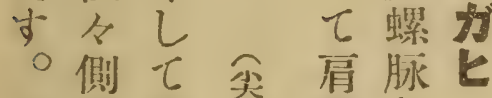

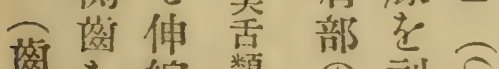

式を縮晸の刻令

第缺性所 ᄂ

第ぐ老界各、

十、有点肩点

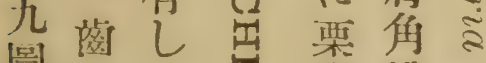

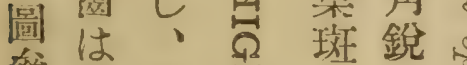

參强水念瑟銃总

照强管员有短

を分罂制

有雖

ᄂ?

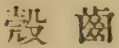

は舌

全は

然緣

外茼
の

一

蝗

含大

抵

橫

t

百

t正

缺火

ざ

毁

は 武

畉

形㱑

s 2

是嵒

?

内至

唇

以

强

壁

刻

L

霊

せ

亲

๑ ล

突

起串

娄

具

役

淡 面
粗 紡

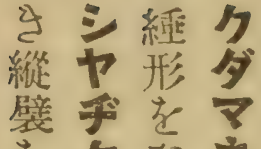

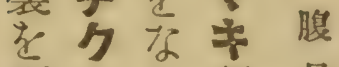

刻○しが足

すき、七 颣

芯螺 す

ॐ度

雇 它 前

仓低怘 鰓

๙. 高 ₹ 類

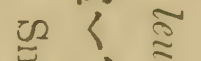

菣、令

巨外官

は品

長切方

二小边

許み比

ज这

中 $b$

部 哲 長

时黄一

本伯 寸

至五。

產尔分

ᄂ 方。

、。濑

水 戶

窟闪

溝海八

知に

! 多

表產

活 ᄂ 


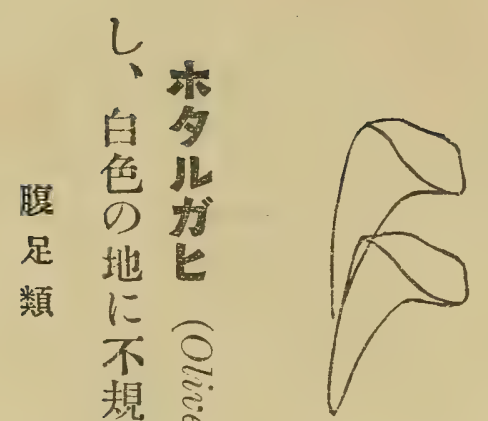

\section{圆九十第}
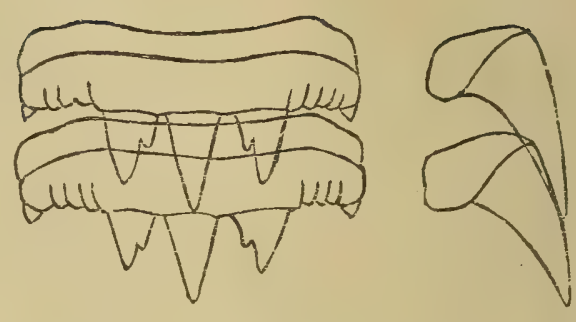

（大放）（圆原）シイレ 式政の類舌尖

(P. bronni Dkr.)

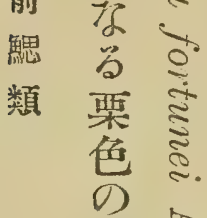

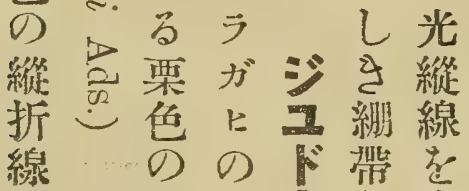

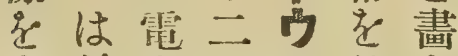

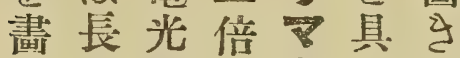

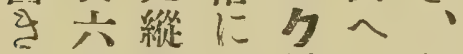

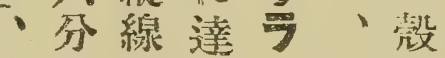

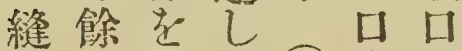

合!基南尺肉狄

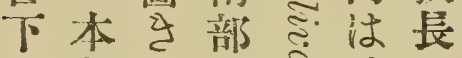

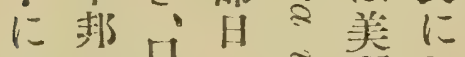

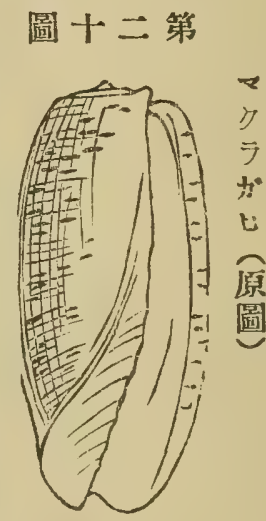

畨

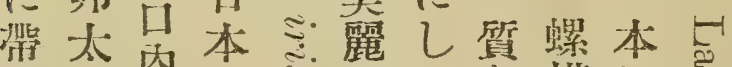

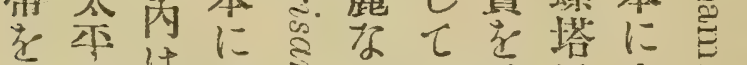

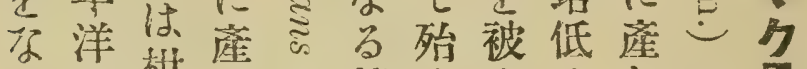

乙 㫛枯乙

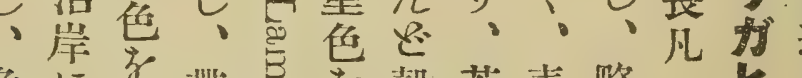

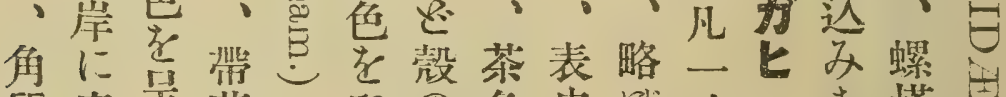

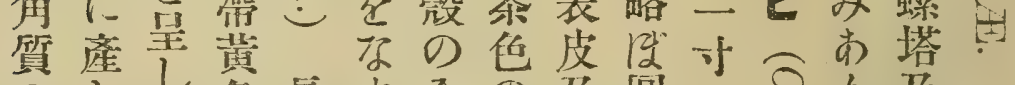

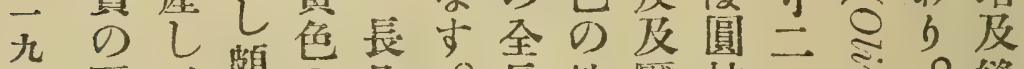
宁 皮 证梦

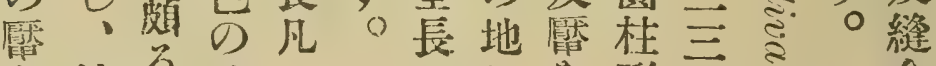

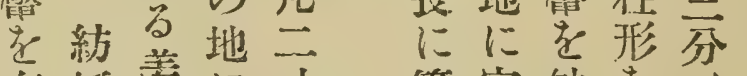

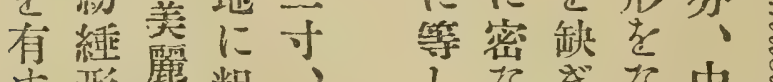

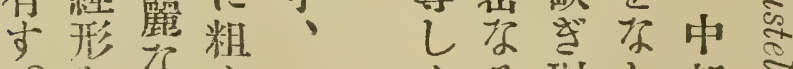

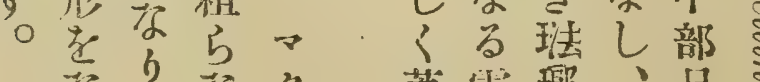

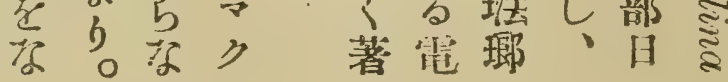
合 i 尔 IJ 浿 


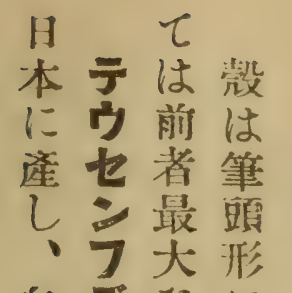

白デに

地包它

に尔

大程、

小類螺科

方密。多塔

形 尽 ᄂ 高

๑ है

罡

黄占 螺

湙顶

色兽 尖

斑長

點 凡

を四

繞五

万于

ᄂ,

知 後

毁く者

口乞 最

规て 大

了脹不

和

外九

唇る 巨

答夕

小形于

谓老才

・永 ビ

丙记

唇、 क

㳊南

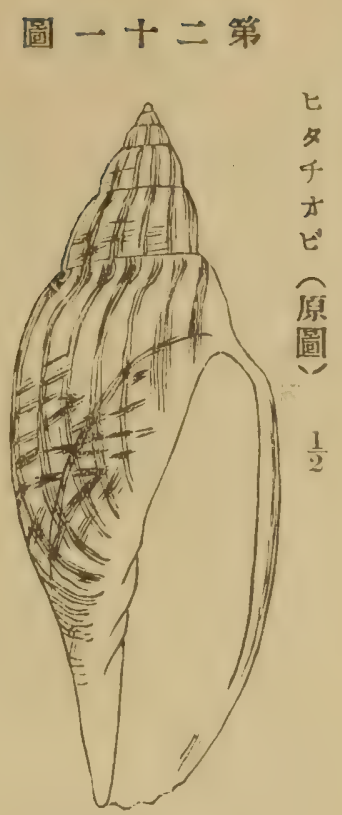

に島の高五

產气種 㵋 寸

し我類なば

國の b加

せ

末 放

- 梊

稀 厚

난 腹

多長足

〈聊飞類

美 美

麗品 충

证卡

乙、科 鰓

七内類

高唇 氖

b、璧《

战

本具至

邦

七に:

多四溦密

歐と八!b才公の

洲を割地・ビ这前

に三は球美一生方

は點七上麗寻。に

之とイににミ切

在し知し文込

見て二訓てき

和畫島れ標塄

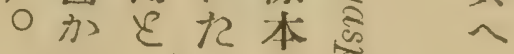

れ二当稀

れ土化

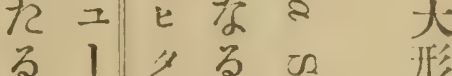

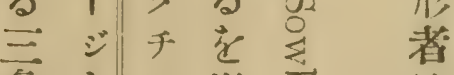

看的以过

形ラビて管

のン屬頗長老

中ド等四有 

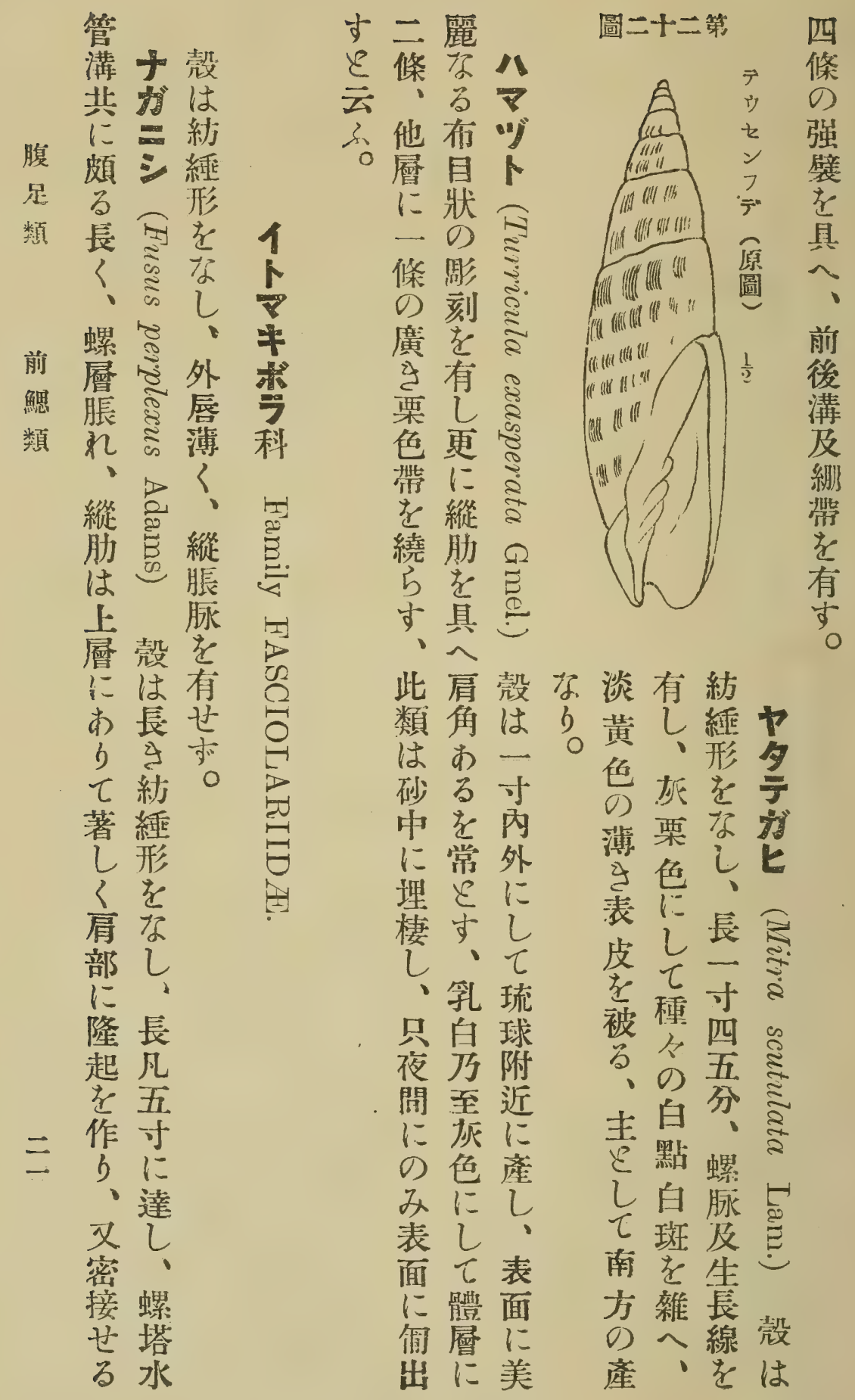

此肩款尔淡有紡

類角はり黄し䋐ヤ はあ-○估、形夕 砂方可灰走 中老薄栗梦 に常外注色～ 理 $\varepsilon に$ 棲主し $\tau 、 \tau$

乳琉 只白球 夜方附 間至近 に灰に の色產 みにし 表し、 面て表 に體面 㑯層汇 皮表長丵 程寸这 被性四 。五ミ 主白分令 點 七白腆占 南琹是生 出に美產りをは 


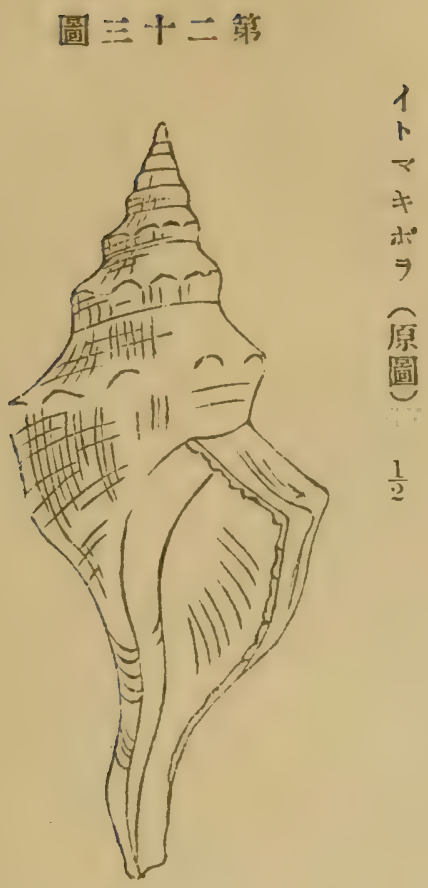

列は覇大

しイ之は小 トを游の

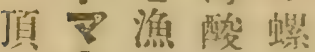

上獲桠胧腹

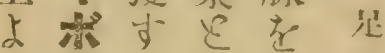

り当穊繞類

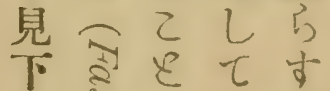

守要如、

と步定自

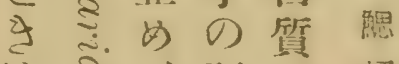

は2・玩に類

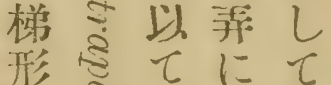

に 卵供活

近气囊甘黄

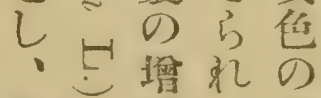

其獲、表

肉長娄稍皮

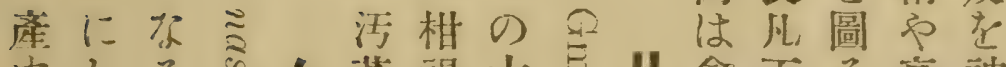

寸しる褐大步少食方高被

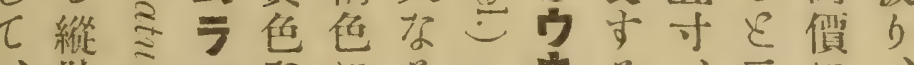

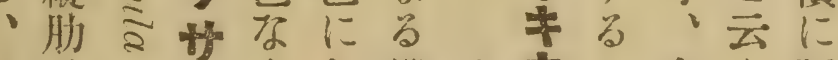

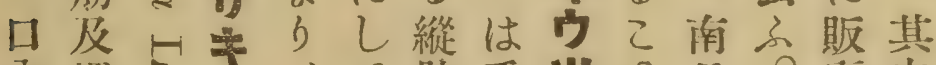

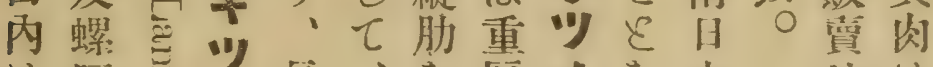

は脉导, 長、老厚范本世は

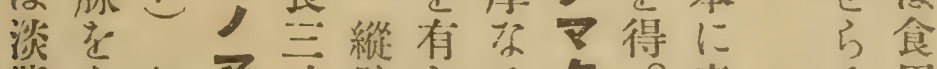

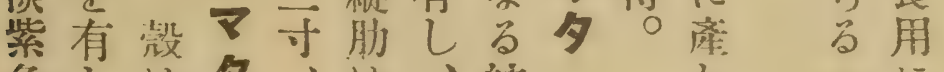

色しは夕、は、紡化、に

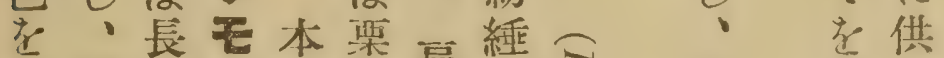

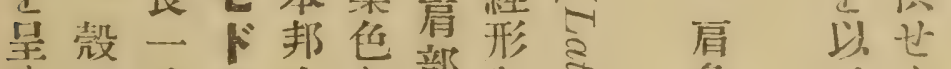

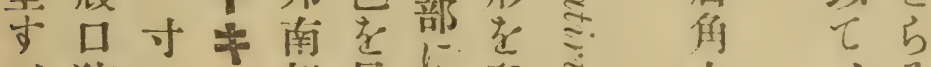

、陝二部旺に埅

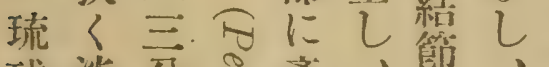

球淡忽紊、節、

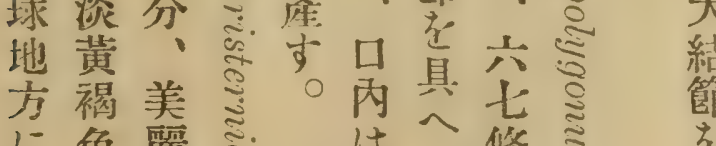

に色麗空は、條芯

上、る

に或

大 地

結方、

節に其

老卵 


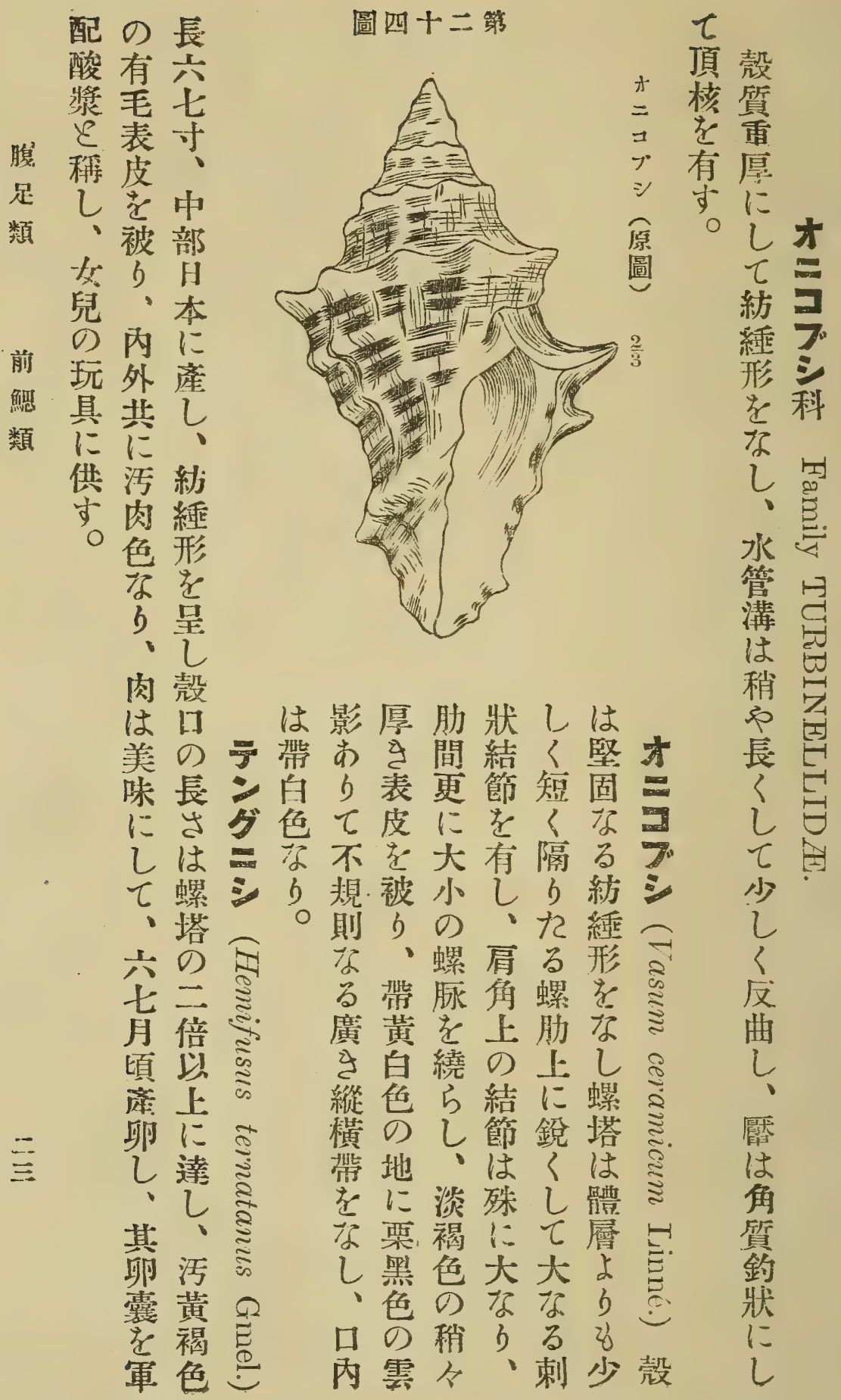




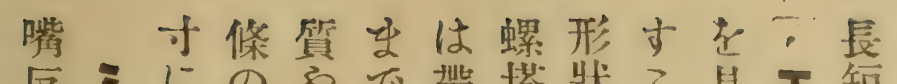

反ミにのやで帶塔狀乙其工短水

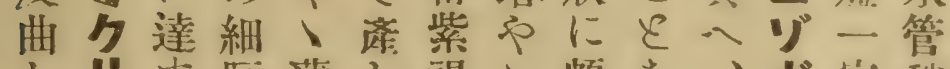

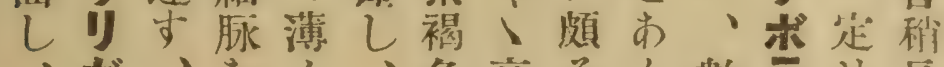

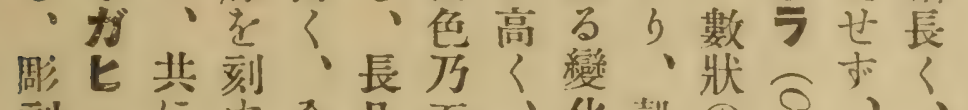

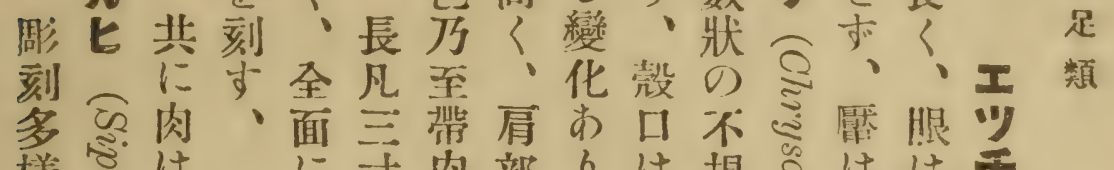

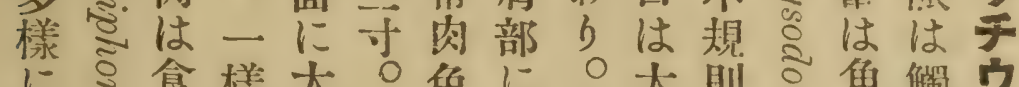

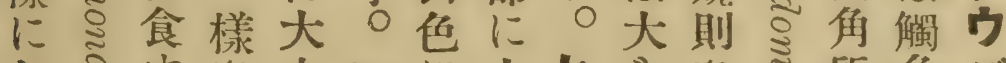

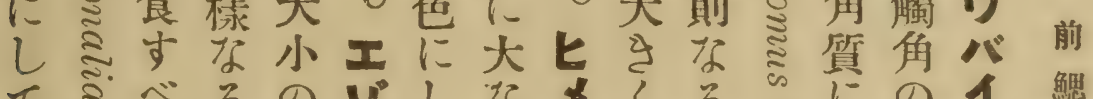

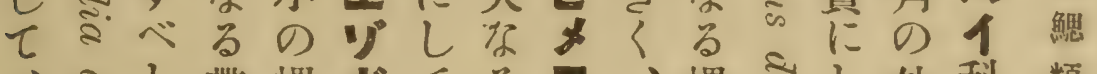

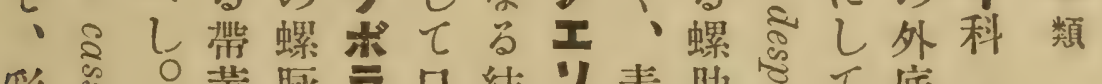

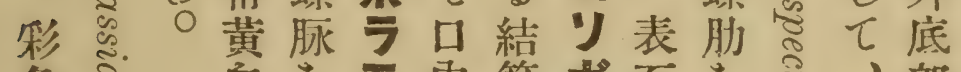

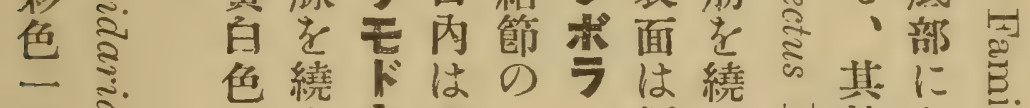

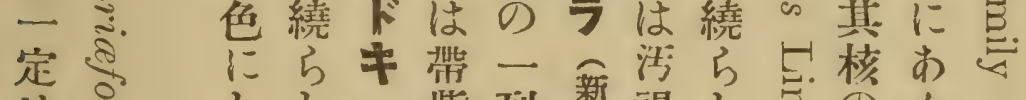

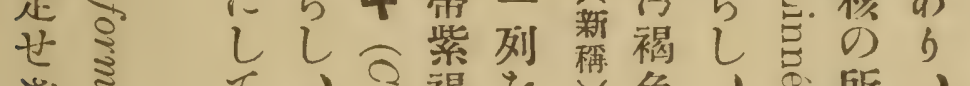

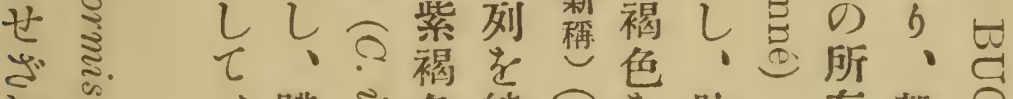

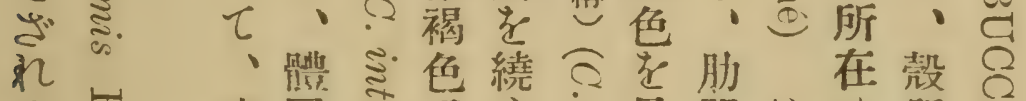

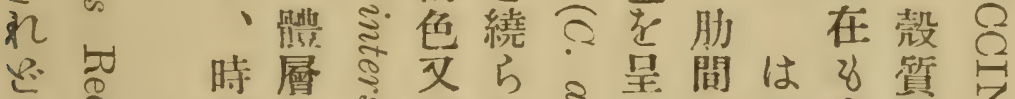

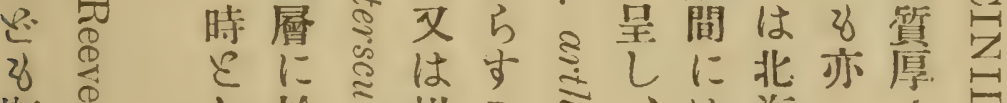

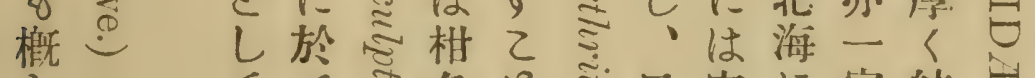

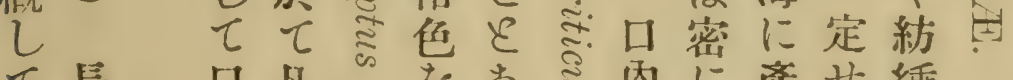
て長口凡娄学内に產也綞 柑一内十呈占細し禾形

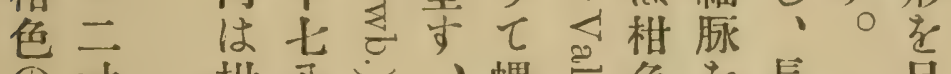
肙相分螺骂色長呈 地: 色條は北脉好紊刻凡 に中老を海は鄫はし五 栗部豆數本の大泉。扵表 色日主游各抵急色局、皮

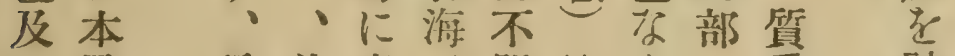
白及長其產、明はbに重被 色韓凡肋乙陸膫小、葉厚可 の國四間、前珎形肴狀 帶に寸更螺常bに地縱多水 及產乃に塔陸、しに璧少管 斑し美五高等表てょを肩漊 點、五亲人㳊面、万起角は

腹 

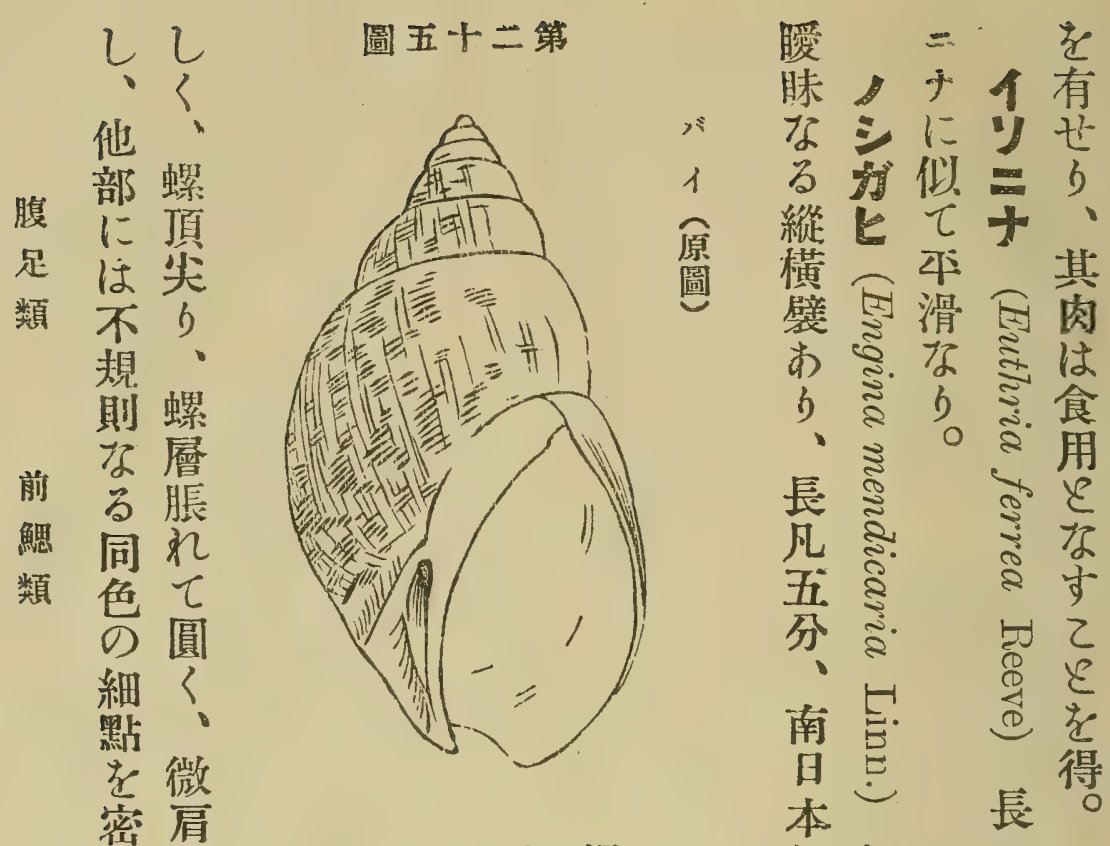

密 肩

柿觕

乙起是。

有了

體し、食光前れ唯

八產內呈愿名

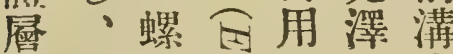

周白塔ミに堦絹

緑質は䇂供るく目と

にに圓文磁し狀敌

あし錐官。白七の稱

b七形

て縫を壳。

は合尔

談下し

玟に・

一紋紫大迅

五は褐 さ

著色略殻

しのばは

〈縱䉆略

大琣卵居

形客に莭

に列等形

色短緱

尔し横、ミ

b、線矢

、表学啠

長面刻厚

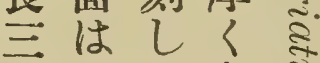

可活、卵交

五白殼圆

分色口錐壱

、应は形

日坐老。

本点圓尔吉

海 8 形し出
に殻

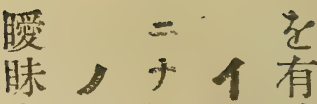

耳比

万似。

綻

譬淟团肉

あ志な志は

り䒕り离

- $\overrightarrow{3} 0$ 用

長 ङ

ह ह

分主

南志这㕝

日 $\underbrace{}_{\text {E 得 }}$

寸

四

䋊分

形

考中

呈 部

乙

哭

白韓

竞國

互箱

の に

横產

帶 ᄂ

走

統形

5 狀

ᄂ 力 
圖六十二第

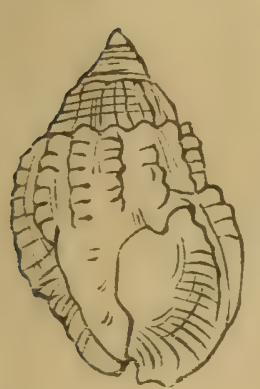

の脹に

螺 辰 は

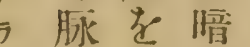

著具带

乙孝。

形

了他暗公有是

、は绝1し尔

表概標

面机尊厚?

面元恕觉概

中本は

央滑淡

帶䚄帶

梦是螺厄

马表、溝少

表它

表刻㿑

面刻磨

は、阴

帶滑せ

黃層ら

灰層れ多愿尔算はれ

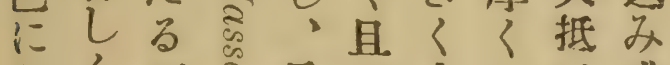

しくがき長つ上! 或

て發如无擴部白小は

滑澾〈公張の色尾短

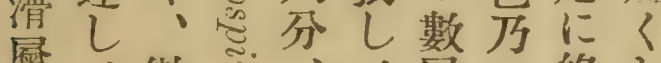

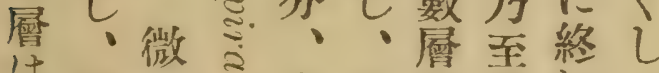

は殻駝〉南外は栗れて

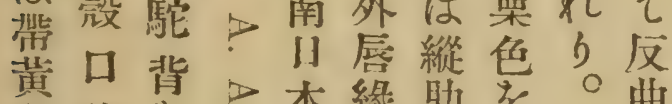

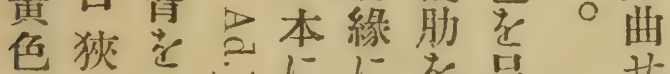
梦人示しにに老せ 与蟹齐微有しる

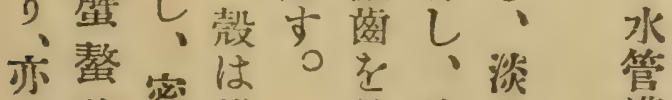
南狀密椎真外色蔧 11 の縱 實 本外肋大 の 䚋とに 產を微し
人唇衫

外

口に標

丙縱品
肉 ᄂ

はて

食暧

用珠

に原腹

供る 足

$\exists$ 寻 類

、乖

バ殾考

1 は禁

科古前

夾、鮊

索

亿丙

獨 は

樂白

色

作

万

t

以表

て面

有の

名斑

禁變

b

透

覞

L

胎

孔

は

小六

に

ᄂ

深

? 


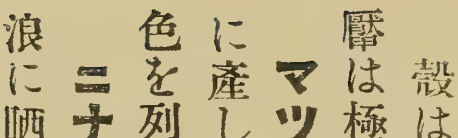
さハし、ム小小

腹起1九紡沓卵

足紅 当絽

類、 2 白形 20

些气丘形々

系带走尔

褐芯学李

前色等尽有し

鰓のき、肩芯

類美导口角市

彩尔内极怘

老はく芯

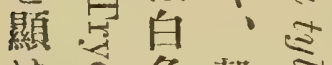

は氖色㲄す

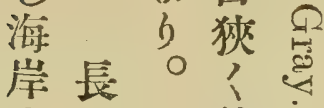

の豆外

砂分 唇長

中ばに五。

にか 苳宍

混白分

在の 具ば

す小的

○ 的、b

1: 黄 小

乙 褐具

七 绝

海比记

濱して

$\bar{t}$

老 科

螺葛

塔 气

知

?

內

唇

は

齒

牀

旺

L

外

唇

厚
色八之胁

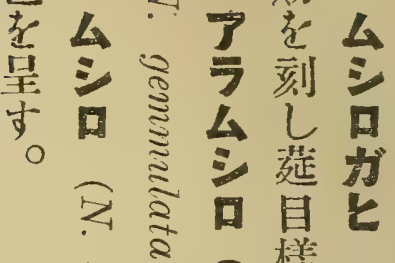

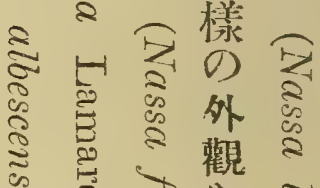

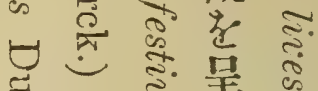

宾は辛寺

退大苟、的

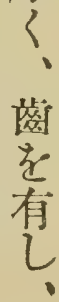

形てはにさ

走脹彫し

次刻て長

乙、粗背兵

鑢鎋くに七

狀刻螺褐分

の粗塔色ば

彫々高のか

刻畄々二

考鱼、帶の

有皇肋尚小

乙色間りさ

结栗。是

白褐色貝

に是量

乙露

は 部

暗出橫

灰艼七の
は形忽帶占

卯已色窇。

頂 


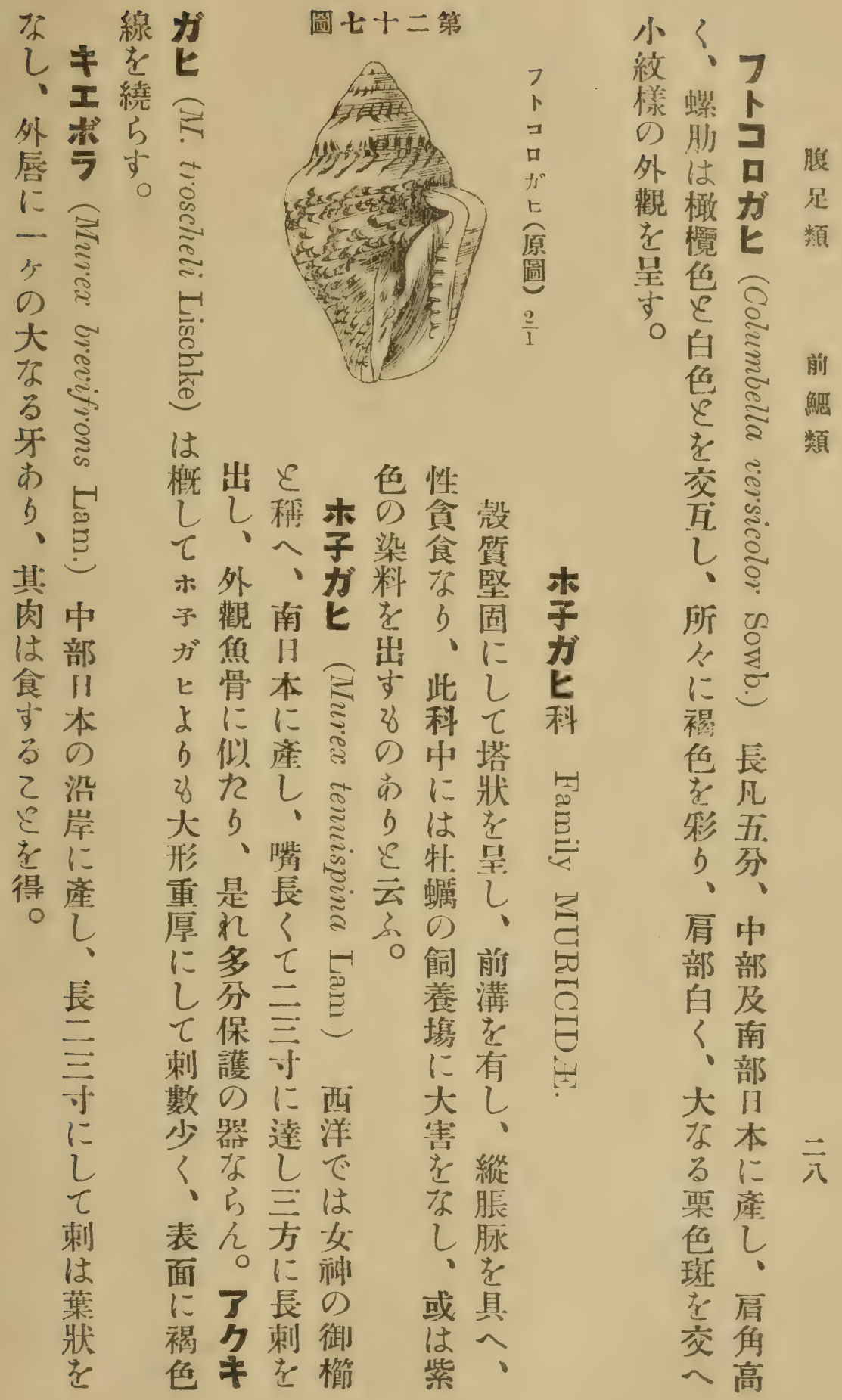




\section{圖 八十 二 第}

腹

足

類

崩?

鰓

類

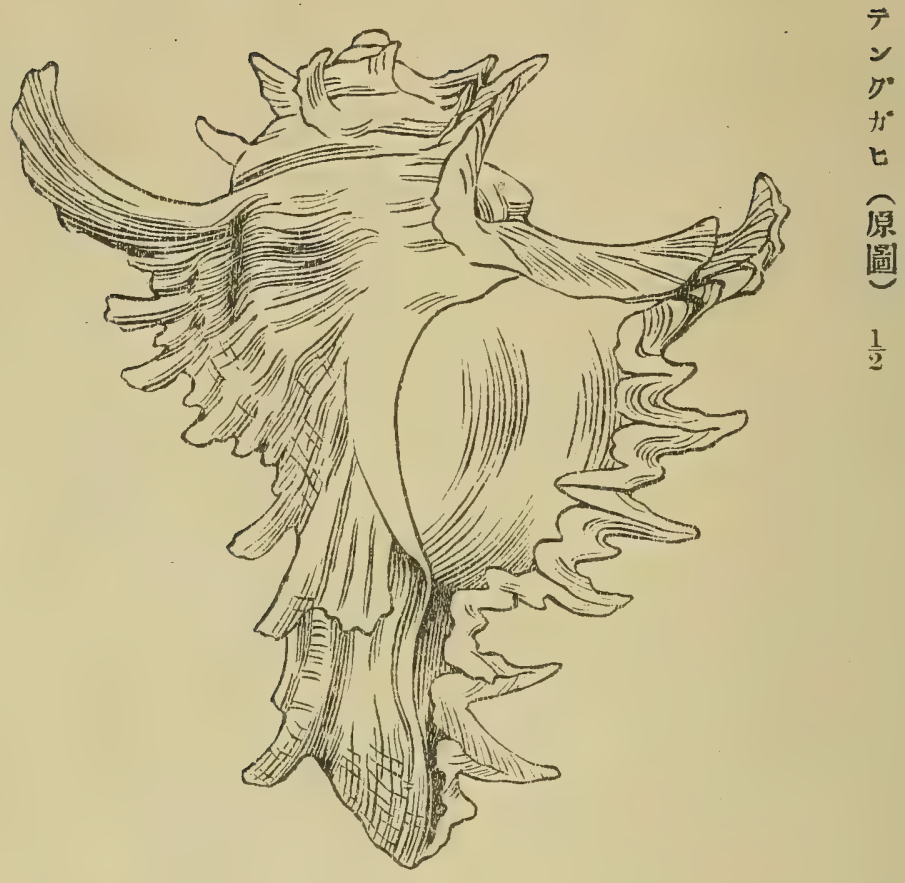

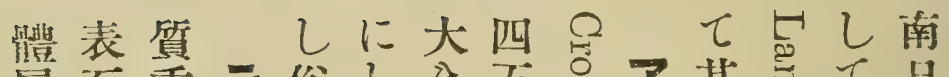

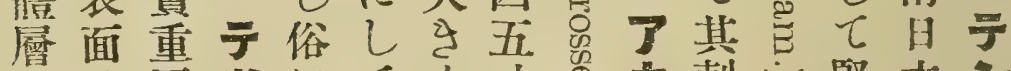

には厚ツにてく过少刺堅本

无䡴、术長其鮮に三密的固に

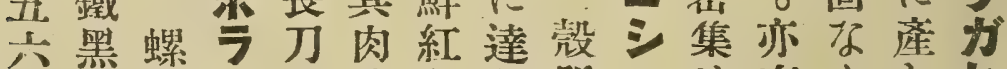

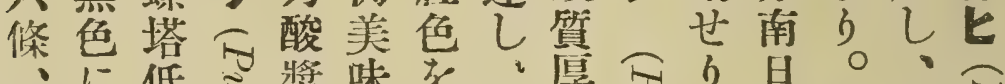

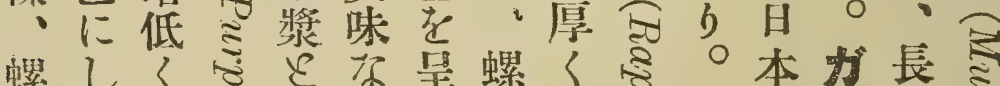

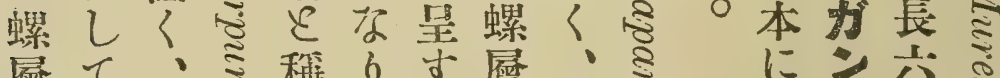

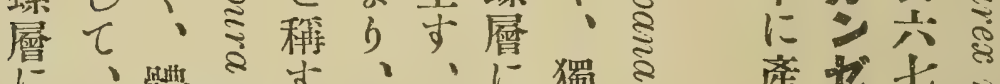

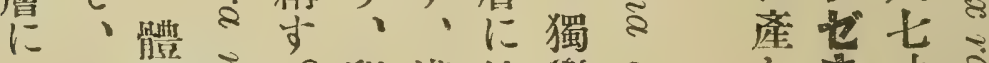

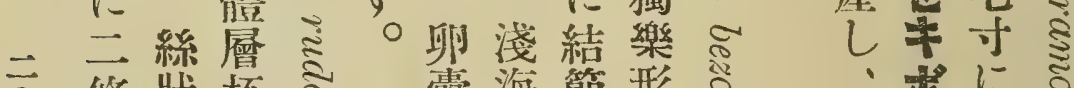

无條狀極念囊海節形芯桀に气

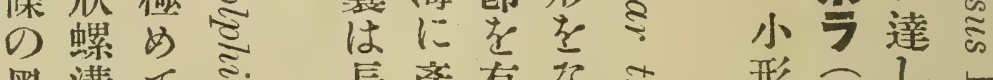

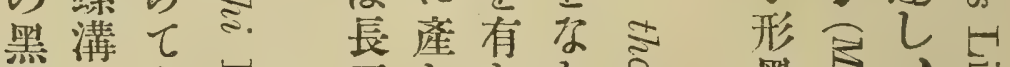

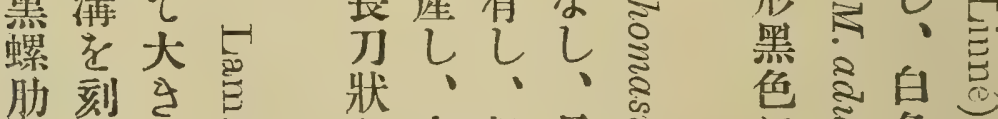

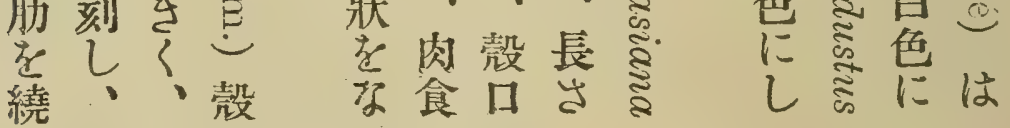




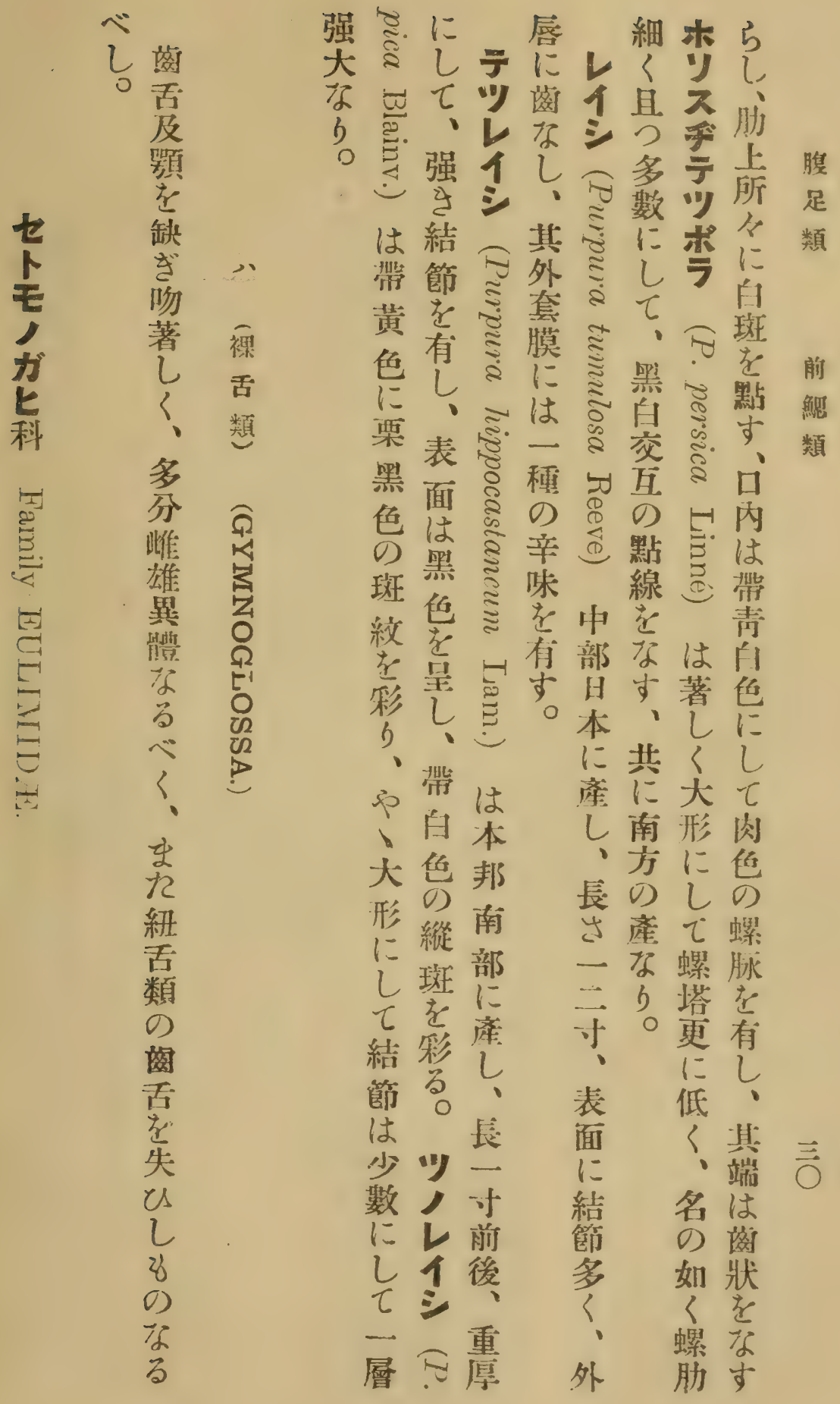




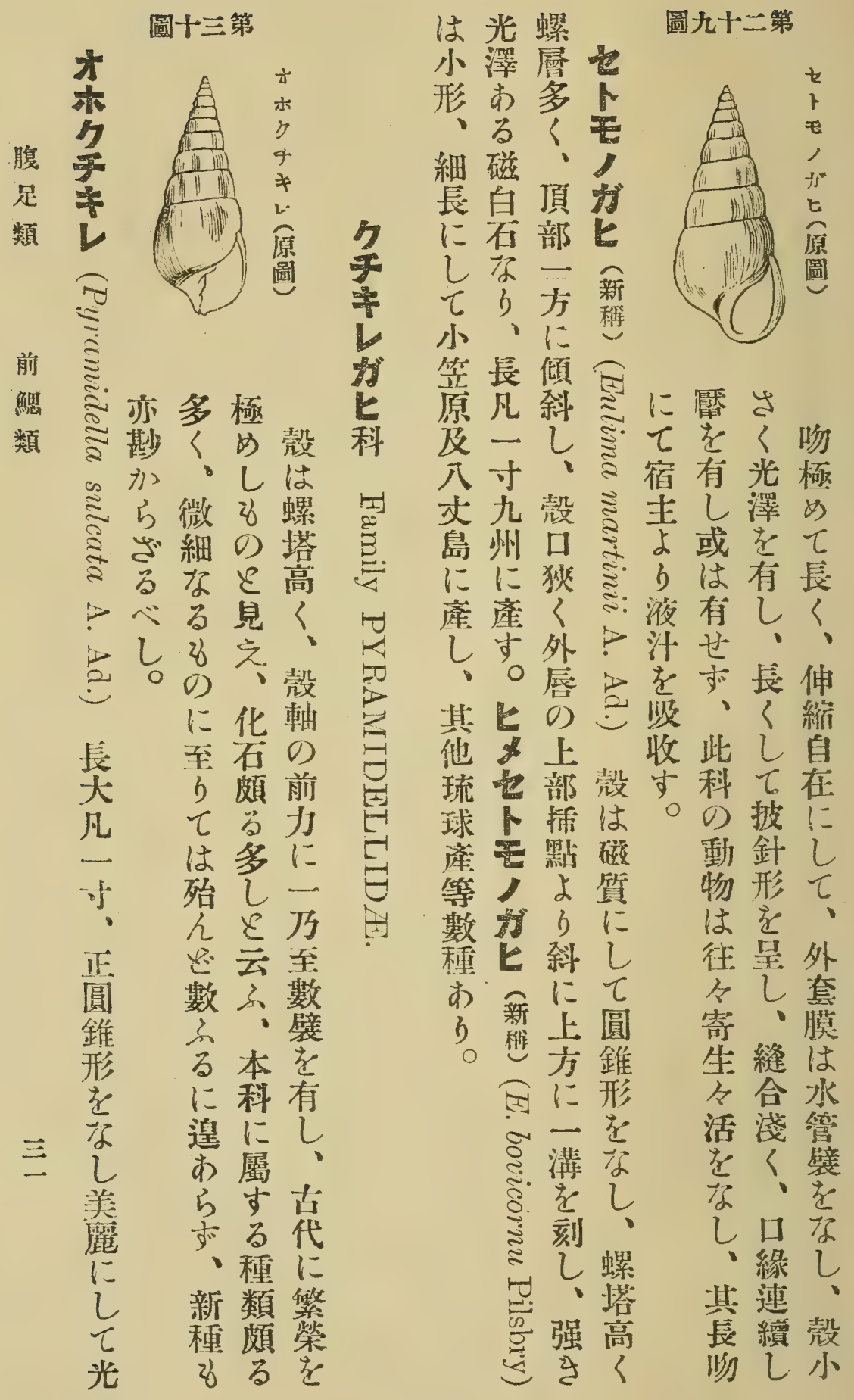




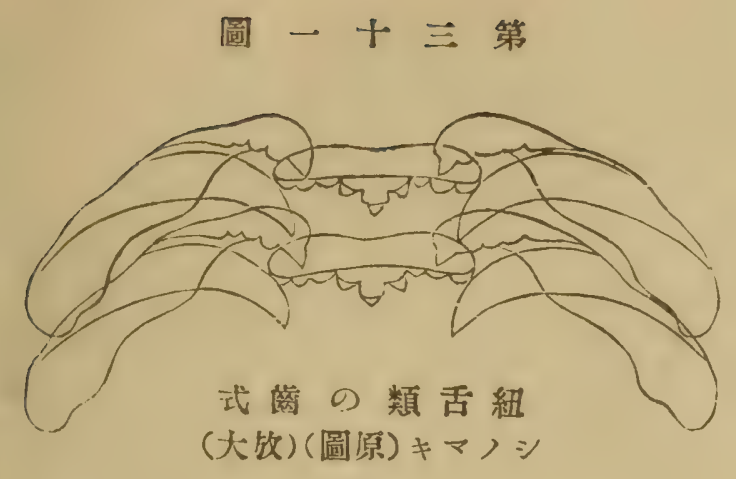

長 三

四力方每

寸可以螺

ば柴上懕

か劣の

b る 紨

- 含本脤

大 丞脉

桨㣽がは

万衫

螦 合族

脉 气 と纪

繞 芯阅

5 던

し 哥る上

粗总之江

毛と澾

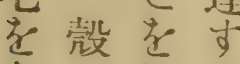

有は得る

せ短べ

弟紡し

表緟○

皮形文

步起

被尔以

b.
はへ澤

短九あ

小る

に时。

乙色螺 腹

$\tau の$ 塔 足

縱蠟高 類

脉石?

比に

刻螺螦

乙溝層 前

- 脹 鯰

口刻 る 類

緣せ

はる乙

弯多劣二幾が

高多劣二常分如衣

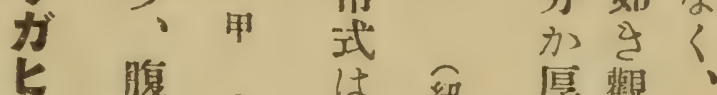

腹合は紐厚蓶

科面扇一舌々老十

尔旺数

吅階

b) t

0 曹數

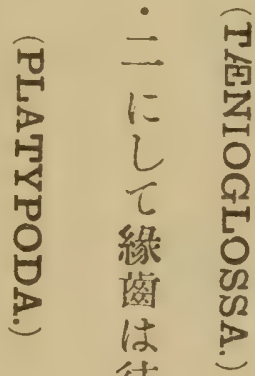

往

㝏

倍

加

古

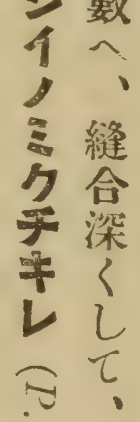

吾恰 三

‡if

微

的褐

>彩

点雜 


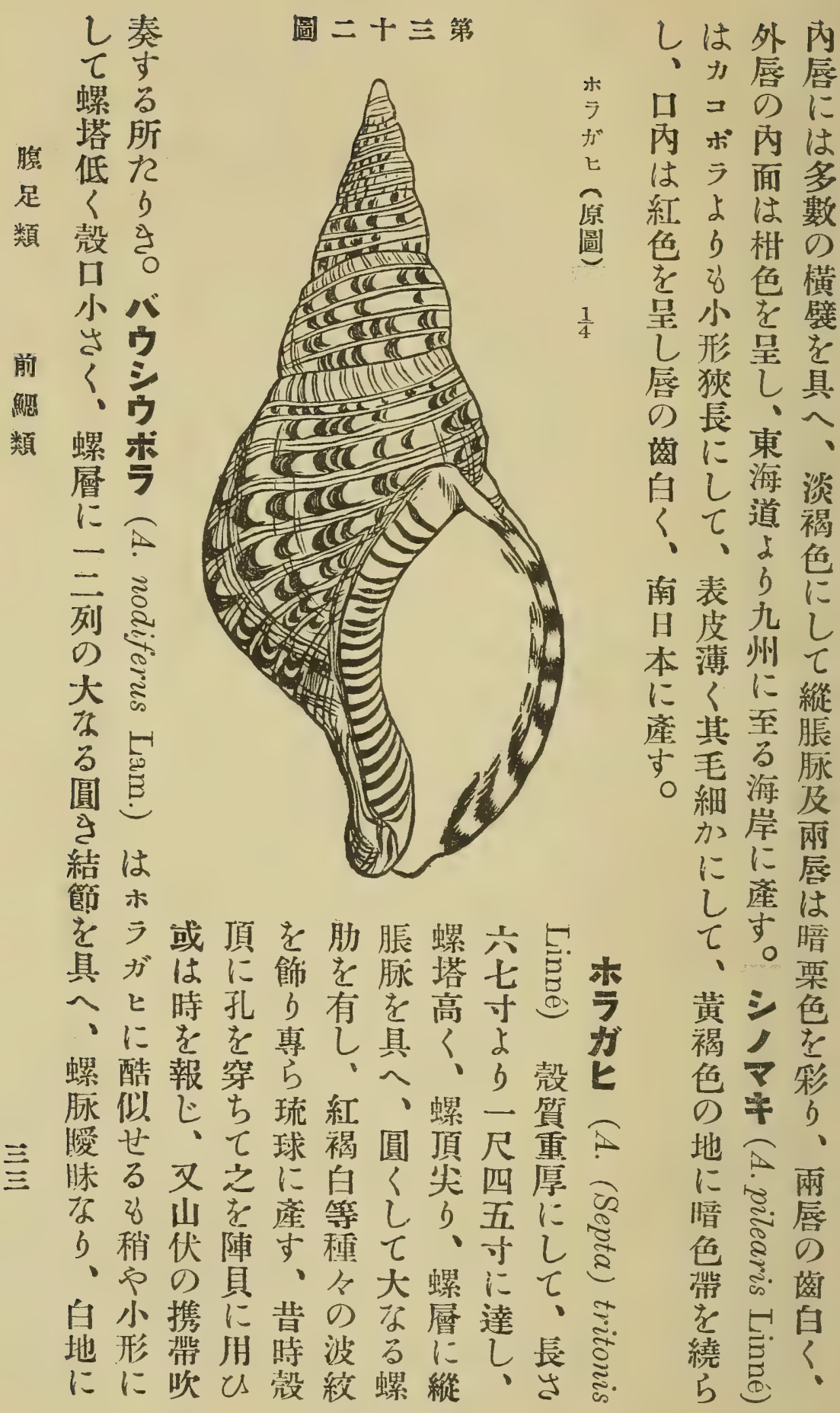




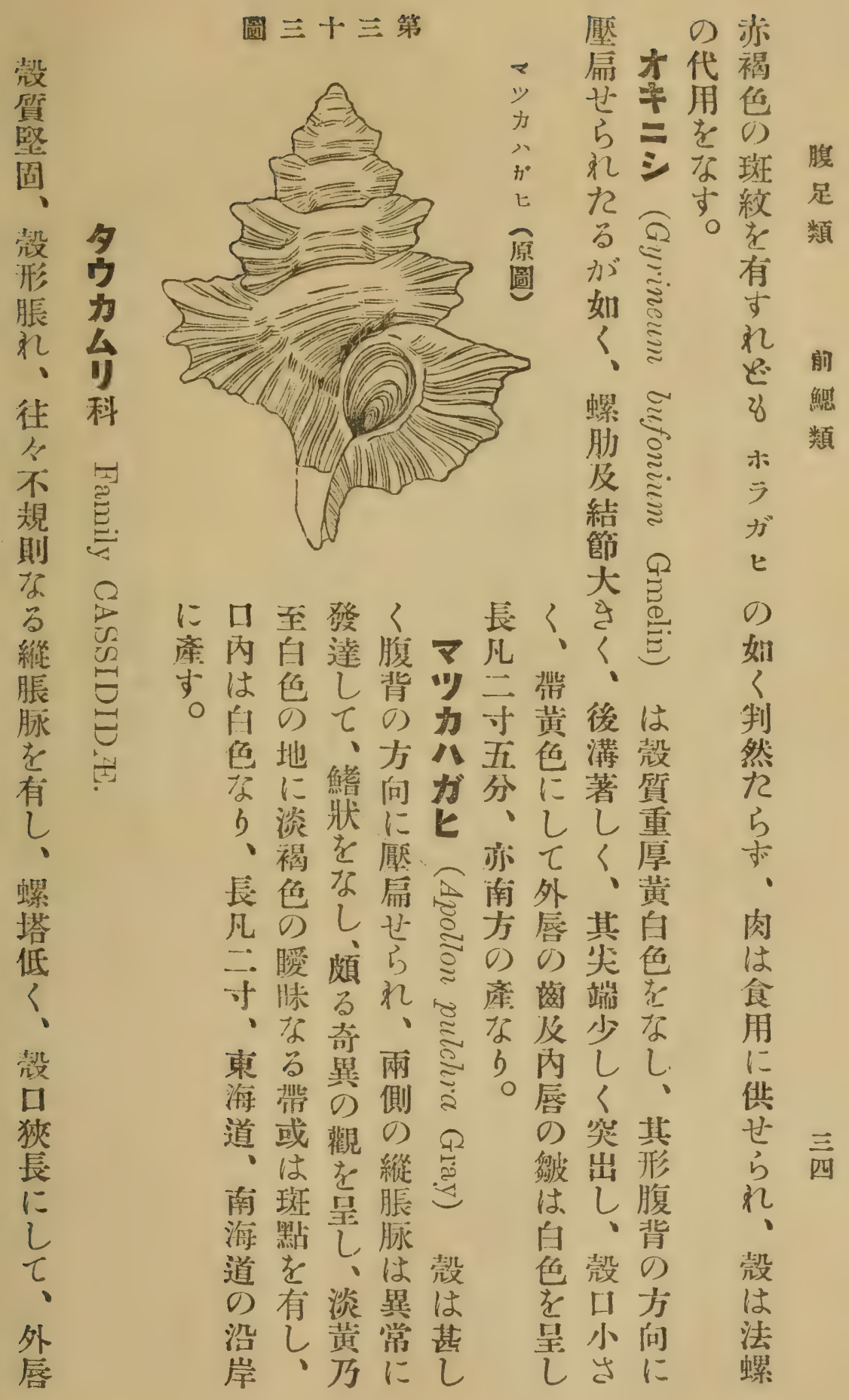




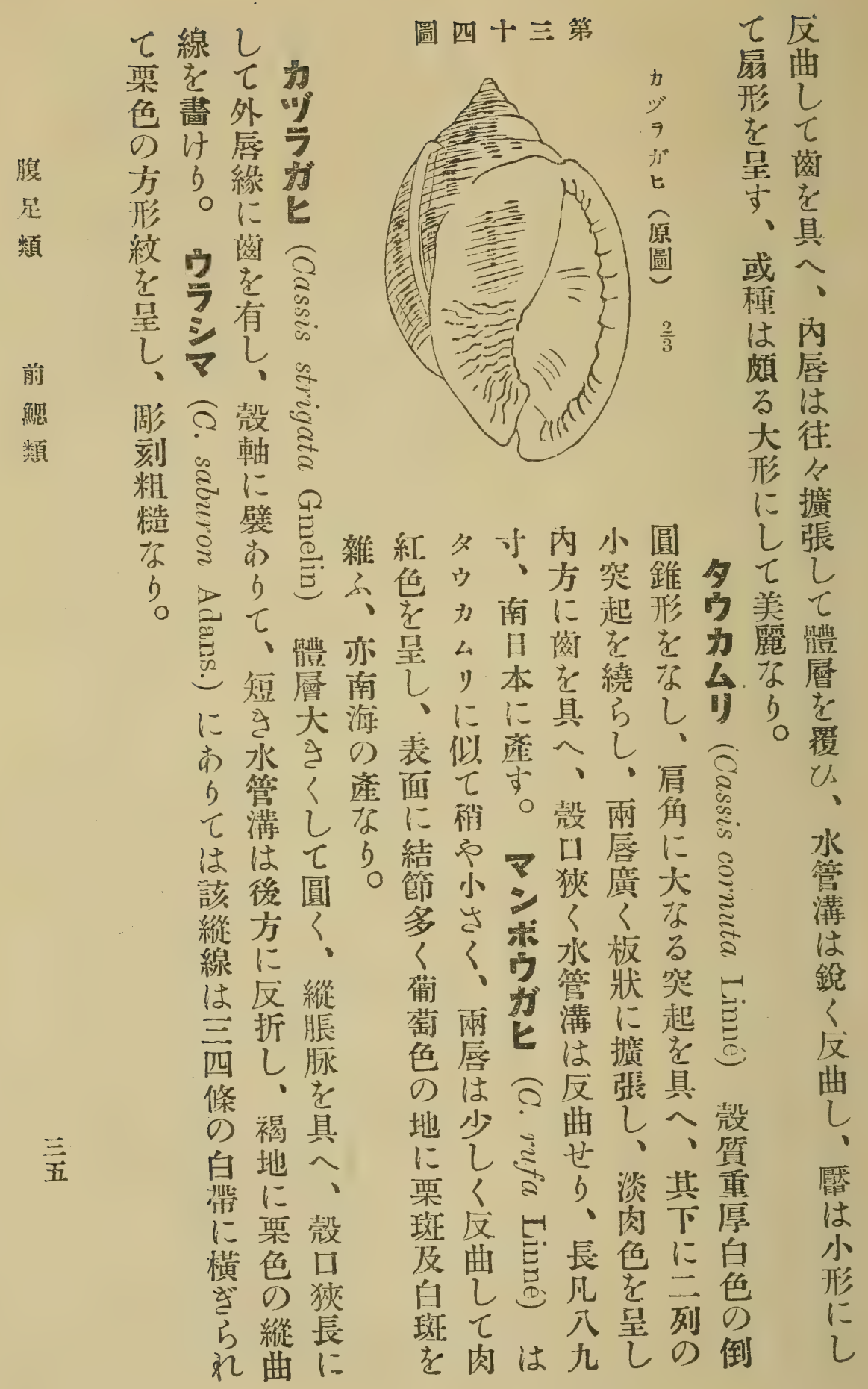


具

家只卵

の體形

珍愿或

とのは

すみ譛

与を圆

所自形

にはの

しし差

$\tau$ 、麗

古胱称

代口る

0) 狹貝

人長類

民江

は ᄂ

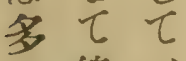

線、今

浆本

在滑

縤なに

貨し

殆 $\tau$

ᄂ $九$ 光

$\tau$ 澤

便凯老

用口有

ᄂ 中

央

支范螺

那縱塔

に貫は

尚尔选

b、郎

$\tau$ 此質

\& 類に

古古理

代來沒

此玩 ᄂ

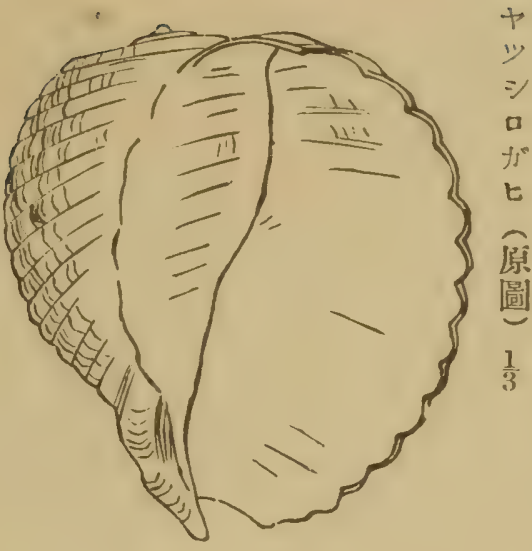

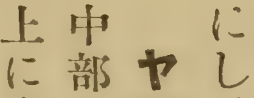

せ 11

ば本

らに

禁產

ちし

漲

褐 淡

點褐

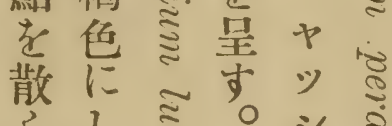

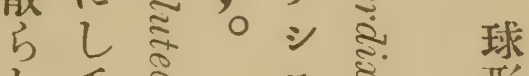

ᄂ $\tau \&$ 口 8 形

球富沓或

政形气至は

口走委梨

頗疗氙形

当し 螦長走

大・塔凡辰

桨大長高四?

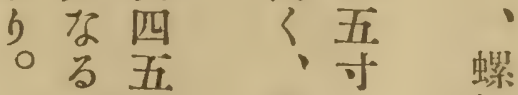

螺 寸暗に塔

肋、色達低

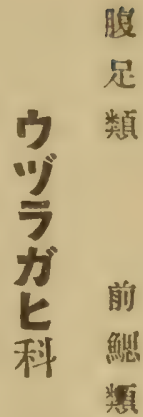

四

总

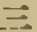




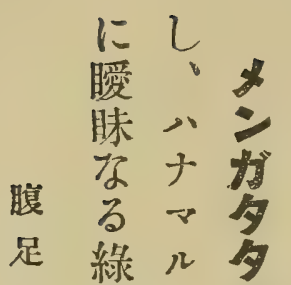

圆六十三第

類绝二

觜 $\neq \frac{2}{7}$

をる岩

前有与 否

鯰 0 小

類
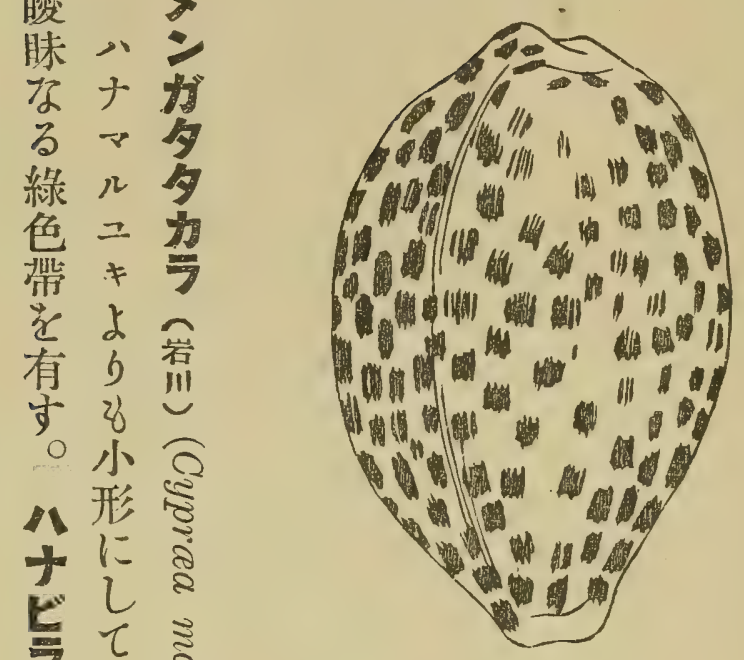

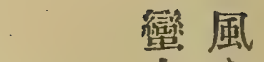

木人全

$=$ の

z

力

間 乙

に学

क 以.

b $\tau$

て 賣

は賀

今方

焰·財

は貨

此

風䝵

常 䀰

与等

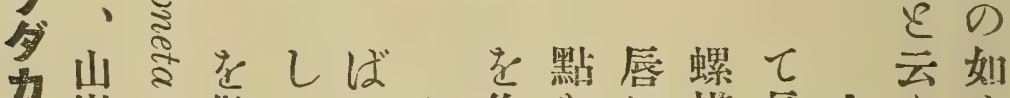

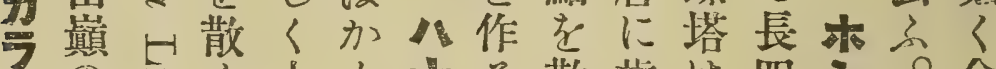
の吉ら小りする散厥は四三人金

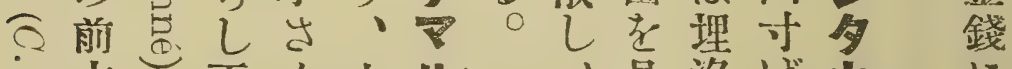

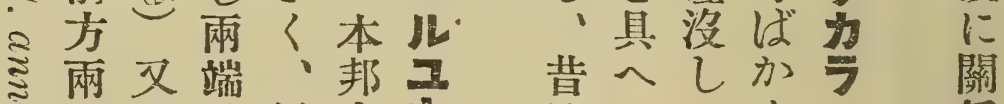

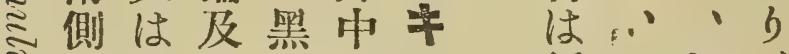

紙白鈠”闰

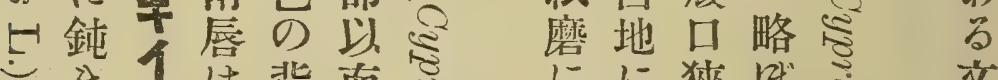

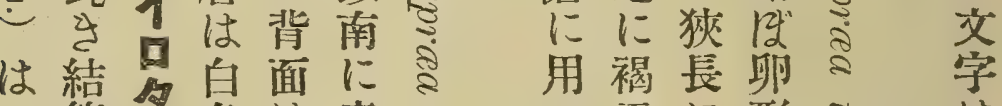

メ節色は產る U需に形ぎは

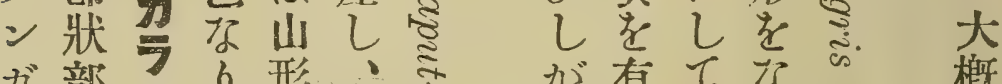

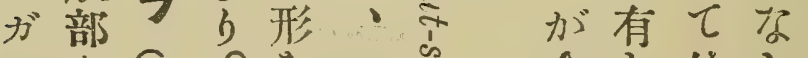

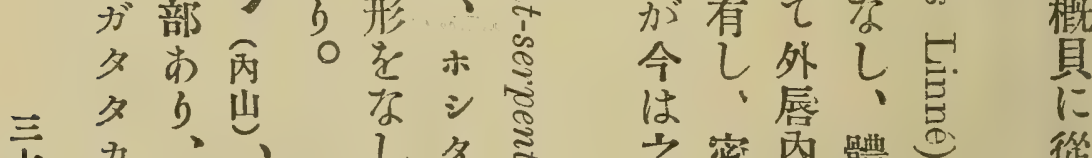

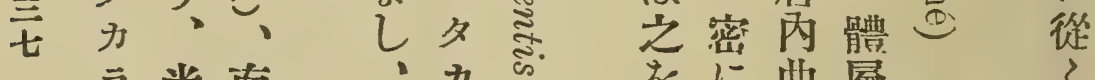

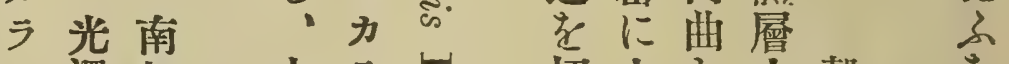

に澤部山ラ毕切大し大殼它

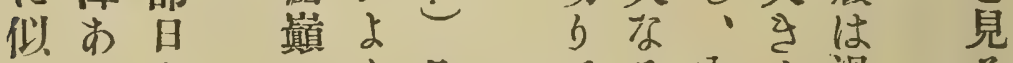

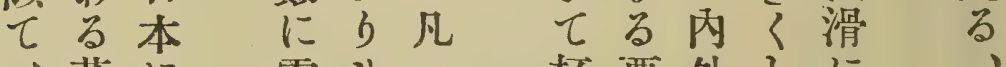

- 黄に雪 8 - 杯栗外しに

带地產底著寸等黑兩てしし野 


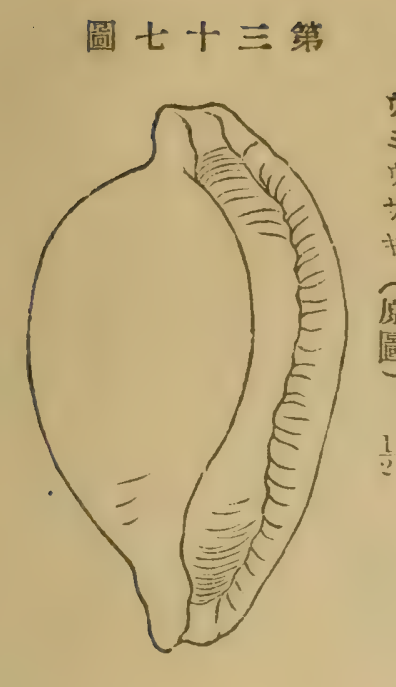

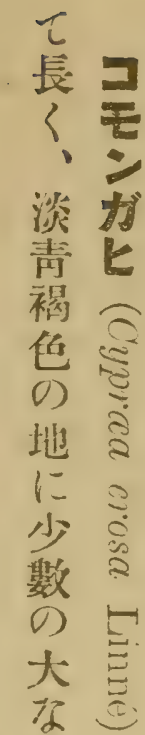

凡面類の内吕

三旺はにウ大部褐献 寸し本似气禁は色部 、滑弓ウる毒蛇 H

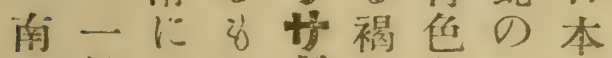
月見し外皆色目に 本磁七唇二方点點產 に器光內 $\cong$ 形しとし 產の澤曲琵、器、 生如あの老苳數大 ○くる度っ有はのさ 磁少芯雨小略

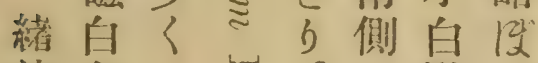
締色、等。點心 、老内擴とナ

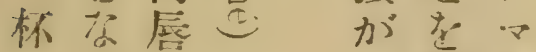
可散 几 七・滛殼 等口学形 走丙有夕 製はせカ 卞暗手ラ 、柑、ガ 長色表七

- 5 工 兩し 侧、气 蛇等

一目 L

万點<

宛のし
は

て 背 紙ててヤ成淡 㧵は管りれ龙 尔步: 溳 —

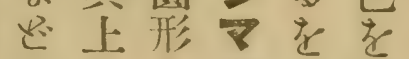

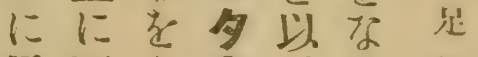

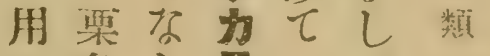
U 比 $L=7$

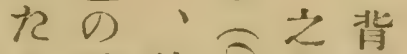

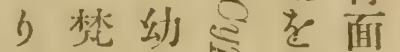
○学具五利 模は2用䊣

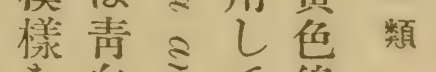
故官て 緑 创の ミ各 の) b地 2 利 㜊 底 $5=0$ 狀

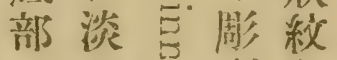

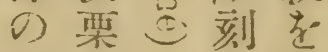

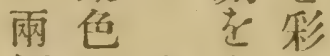
倒 0) 本 \%

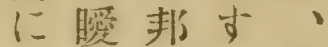
大 11 米

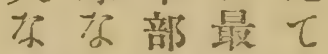
万文文 of

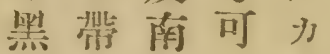

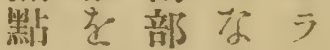

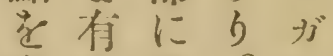
政 古 音 0 七 5 端 類 ᄂ ए 、约產跑 佟成 $U$ は は長、異六 柇边大移 色 $2 y$ o) 尔 祭 二 唯

b 监 三 - 15 of 苗市比 


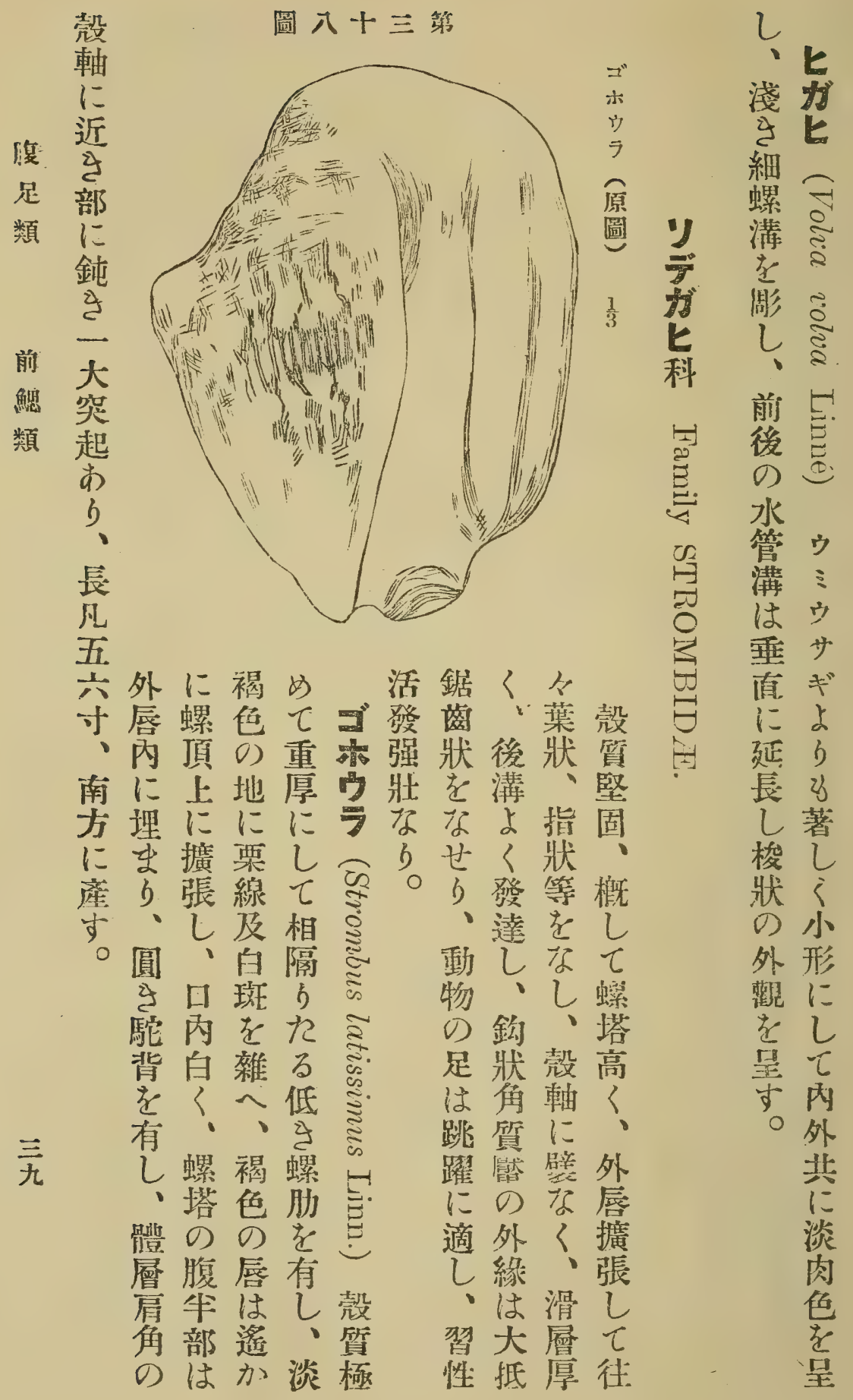


此 る以地

のをてに

如以神褐

己元色

展之蜀分

動に籠

物似る粎

口年之紋

擬当と变

腈他有。

$\varepsilon$ o) 朝 L

は具か、

云甜に

交有生内

桨毒当㴒

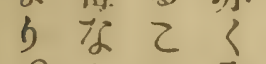

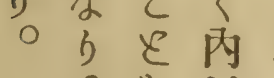

と老

䛤得白長质繞し, 長

認心゙く兰曲ら、兰

せ乙芓寸しし滑寸

ら具门螺層餘

れ元飞南口脉は

乘䛤部內著擴日 鰂莩占及は張本 類具易中白々也中 等罡等部し、尔部

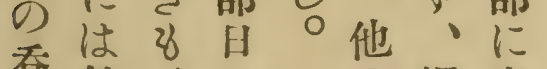
飸歒、本の螺產

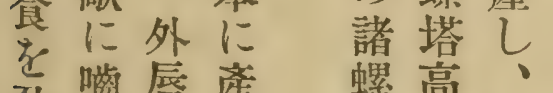

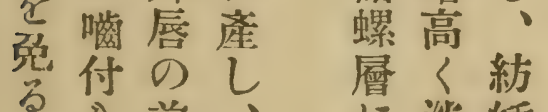

与前:に淡繝

有部䒚

毒织具

学留形

尚当所に

告敌市 ᄂ

亿の

南是
क) 蝎形

色色党

は常し

縱 E

胡? 袖
白節

$>$ 所

と あ)

滑〈、りり淡 り

䧑 足 類

前

鮚

類

袖デ內紅

被の唇色思

娄の老

滑呈

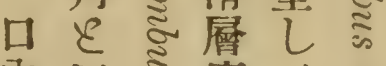

内的廣外
鮮せ气置唇气

紅当珠は

色嘴色袖总

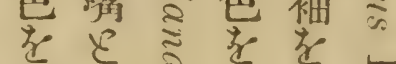

禁度可

守延占记

全て長

乙長腹厚凡

朵背面く竎

与瀿其。

背五Us前背

面分て後面

は、螺淎白

淡南塔に

褐部に近大

色日達尔

に本す部る

白に。分結

點產に筇

をしはを

雜、緣具

四 

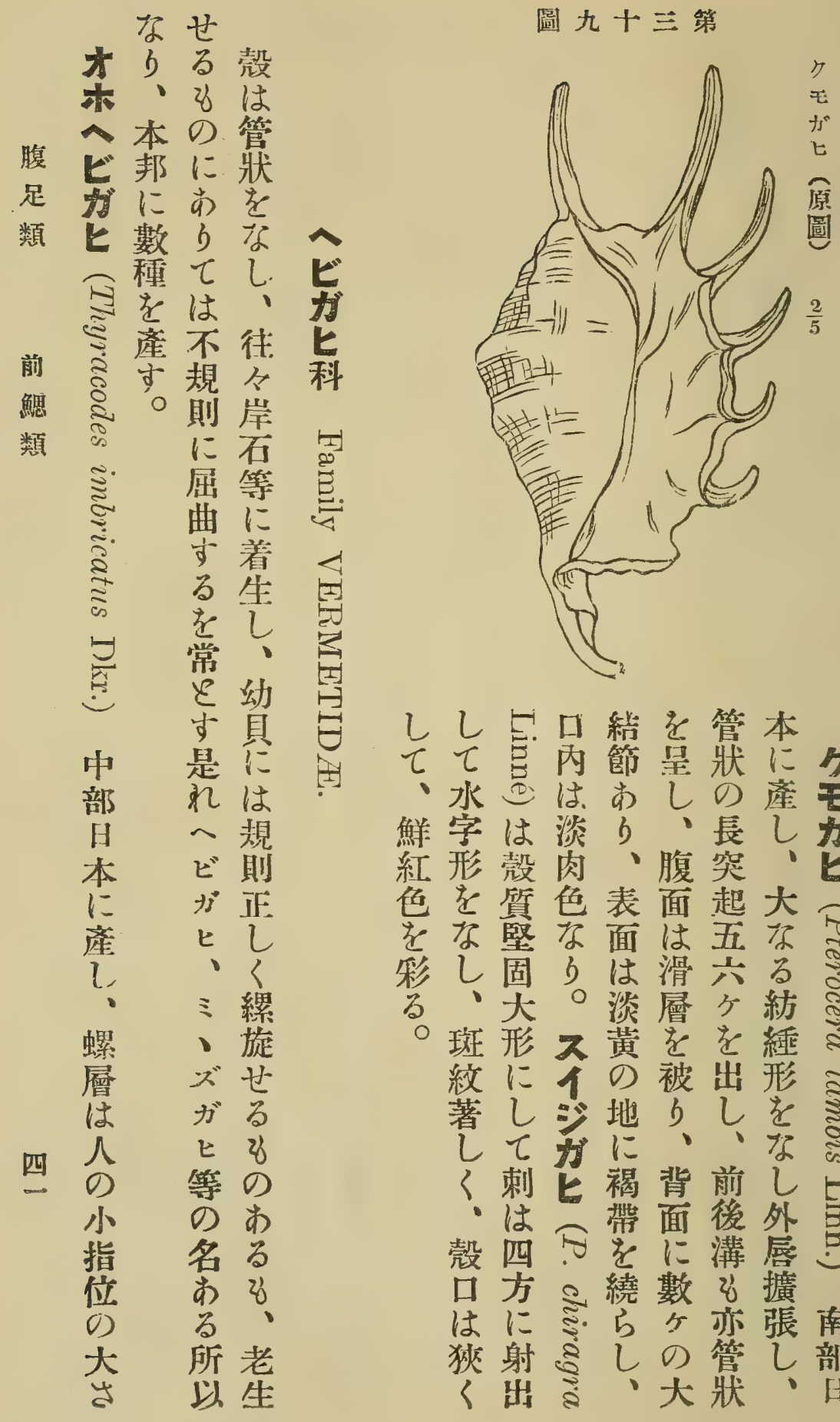

ししに口絬を管本 てて 吉節是狀にク 、水鬼は中しの產王 鮮学は淡b!長しか 紅形钲肉、腹乫、七 色学愳色表面起大无 彩し固了は滑六る

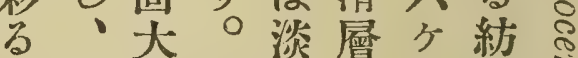

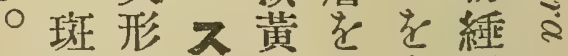
紋に1の被出形ミ 著し 地 してガに、桨 〈刺七褐背前し 、は帶面後外 殼四守に溝唇导 口方乞繞數 \& 擴 はに芯ら分亦張南 㷋射 し の 管し 部 人出乏, 大牀、日 


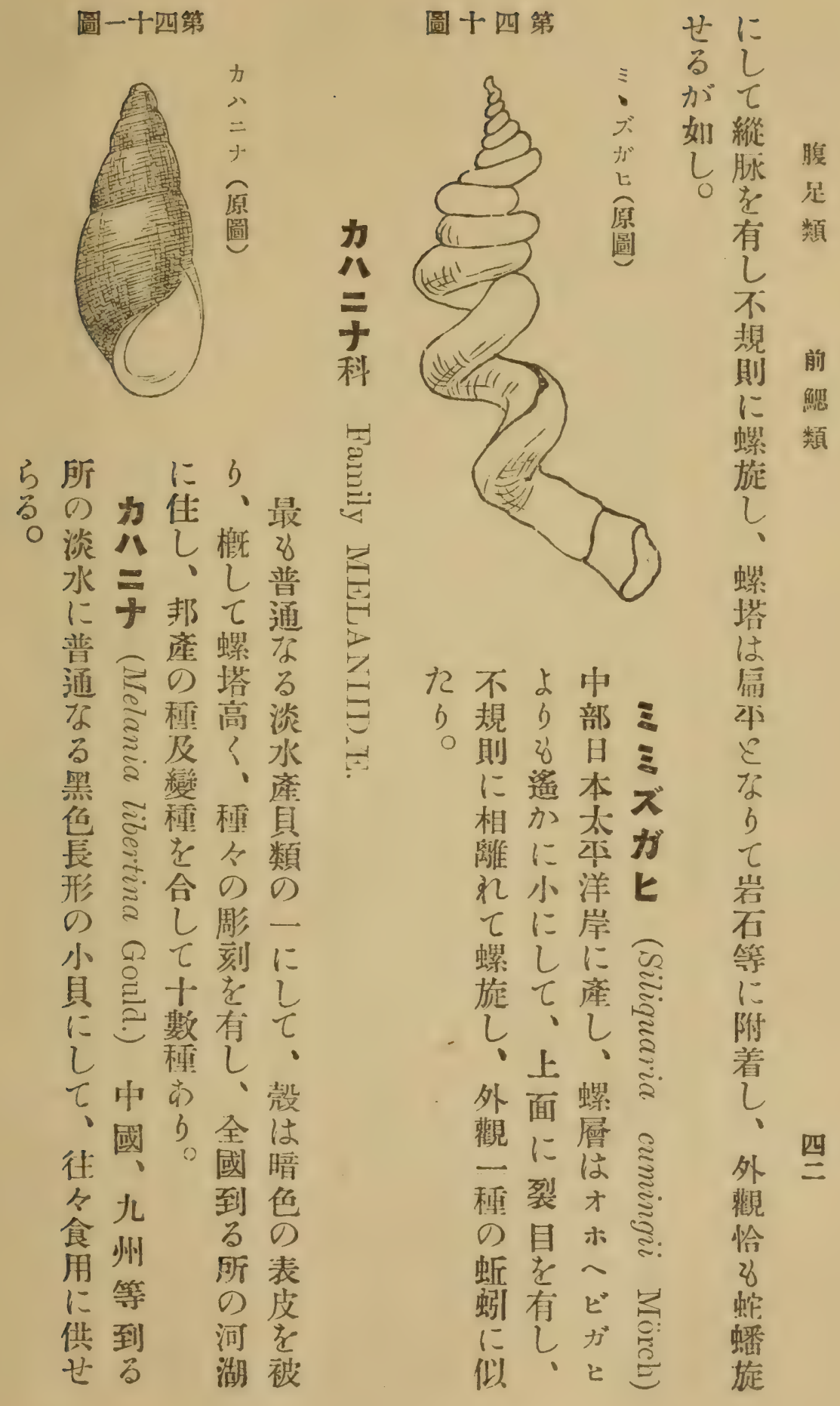




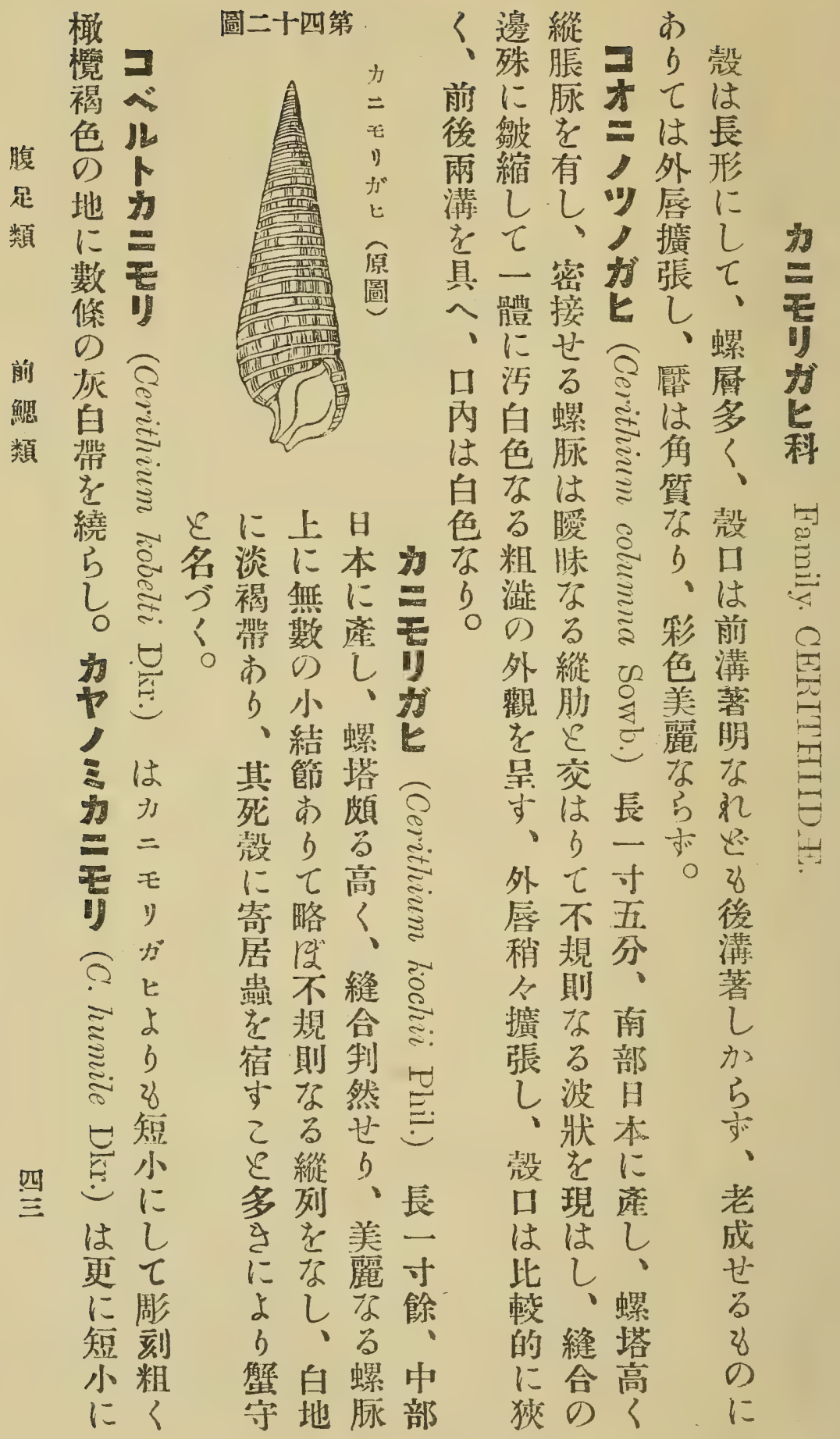




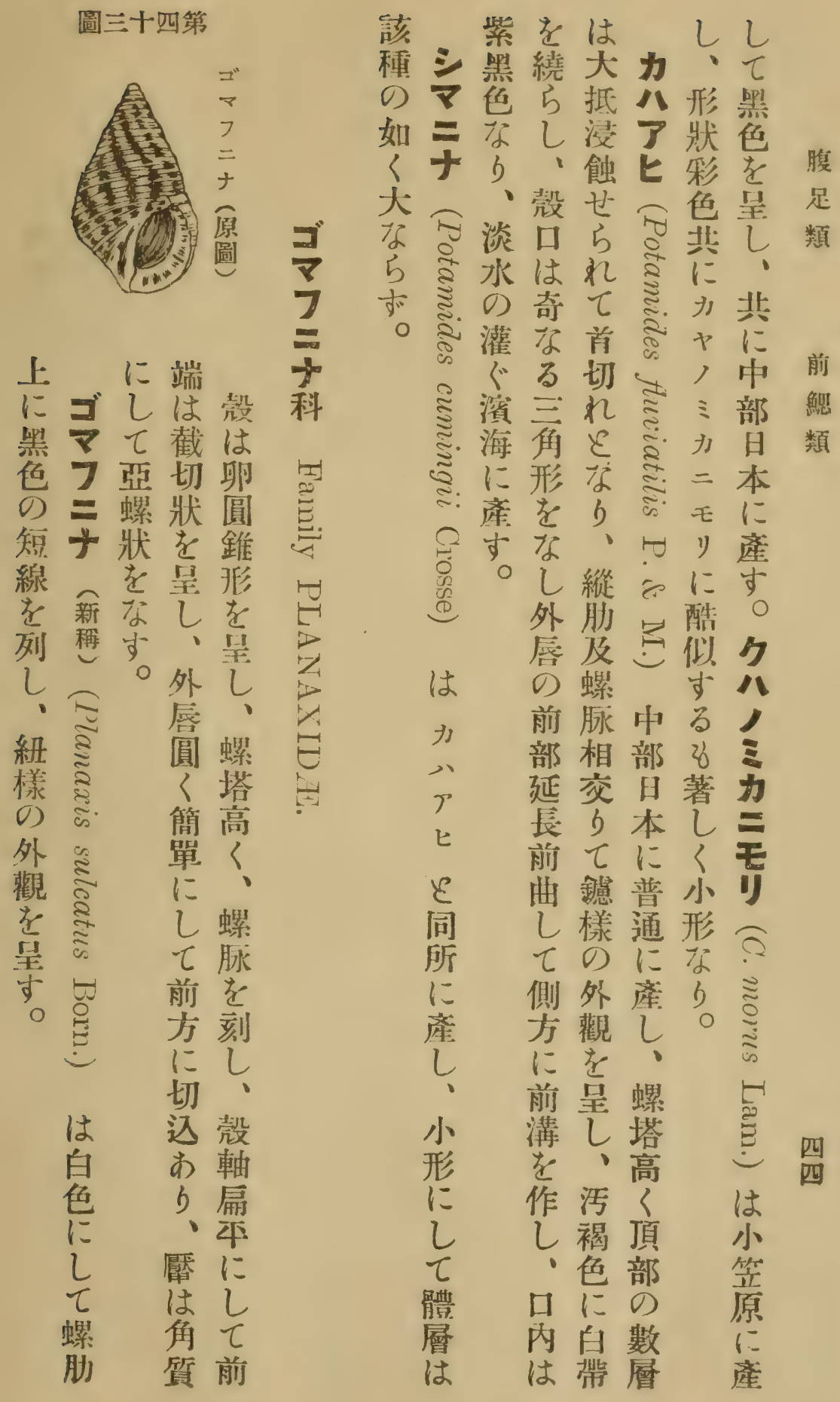


有 動

乙物

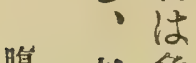

腹老象

足 成鼻

類 世極

しめ

is $\tau$

の 長

前にく

類 b服

ては

は 無

俩

螺满异

截

切 觸

等角

るの

基

常 部

民後

卞方

-

海 位

瀷す

江

產㲄

しは

四空小

五氯圓

筒

呼 形

收に

守 ᄂ

$\circ \tau$

曆
圖四十四第

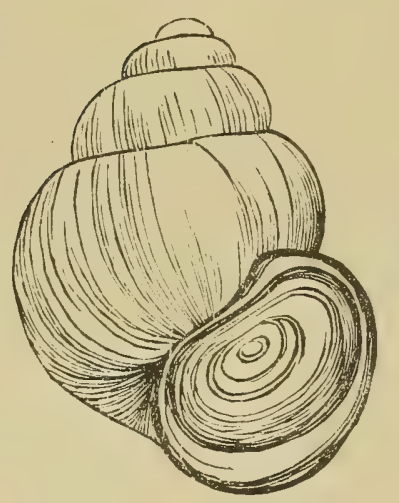

『最

表 8

夕皮普

淢通

は桨

原透る

圆 明淡

の 水

渑產

量具

表類

皮り竟

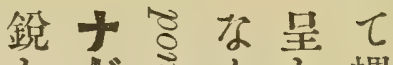

乙 步

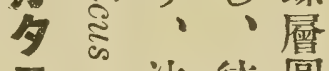

池往圓

邓沼名々三緣は

总に不、完卵

き多規凯 人 非

は は則口矛、老

ミ゙、疗は空往常

大肉了略气令民

心形は暗恼㐫食し

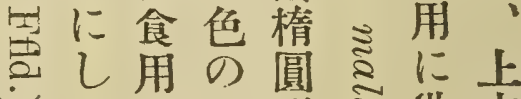

$\tau と$ 縱形呑供方

は周な線を壳せ角

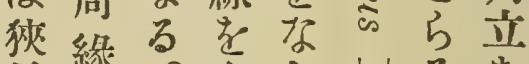

長螕口有し些るち

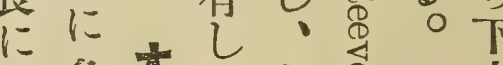

乙觕材、表边方

て多內面圓

周有三面は穀了

緣し三は帶質带带

角子㱖灰薄緝

最棉色色し色 


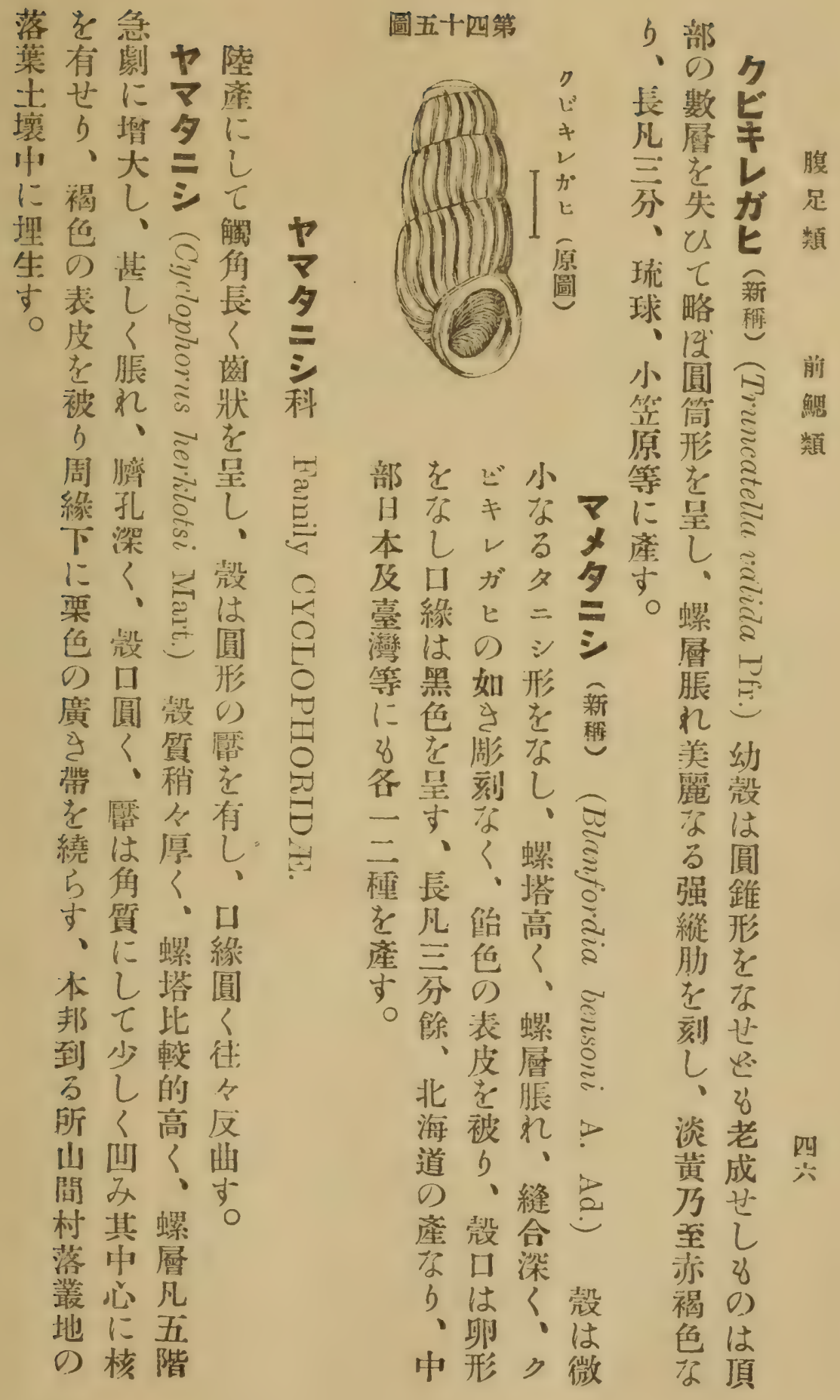



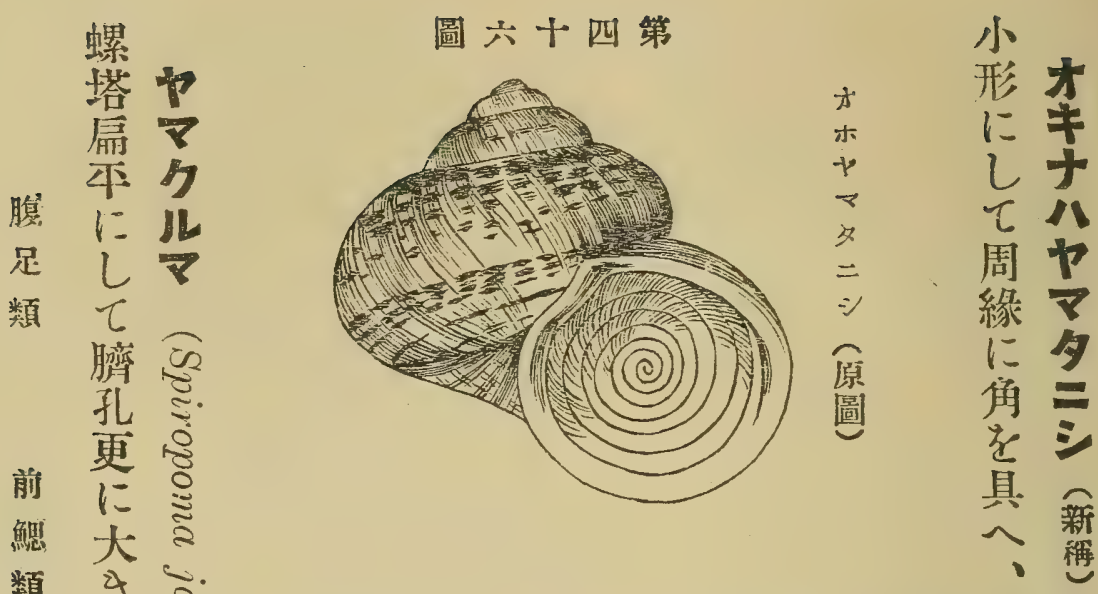

類 \& 2

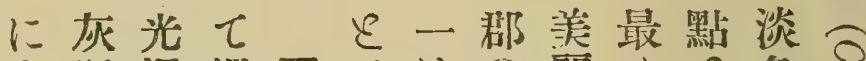

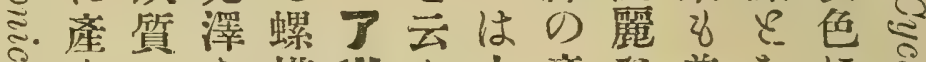

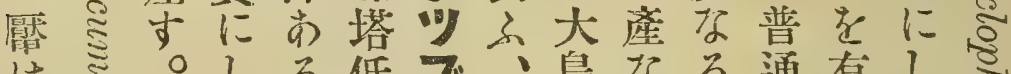

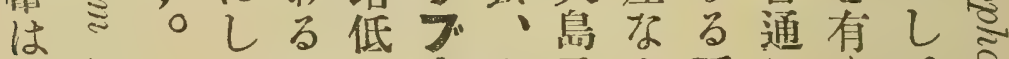

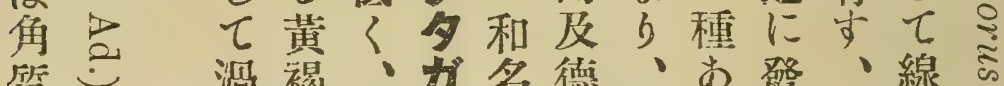

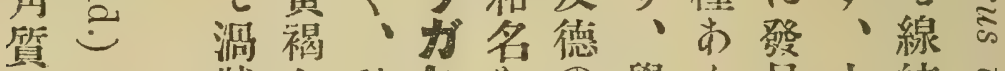
牀色稍七星の學与見大紋玉

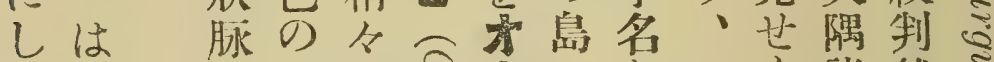

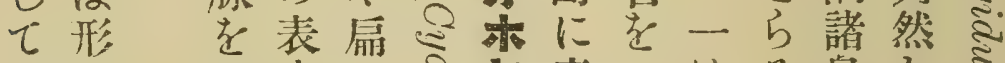
螺色刻皮本含ヤ産は当島し玄

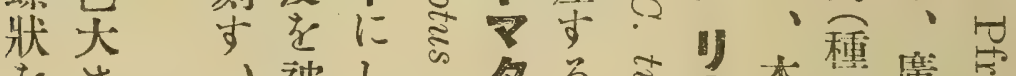

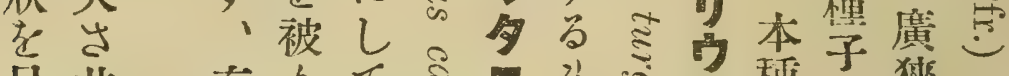

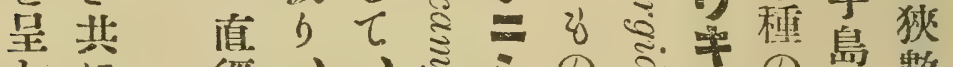

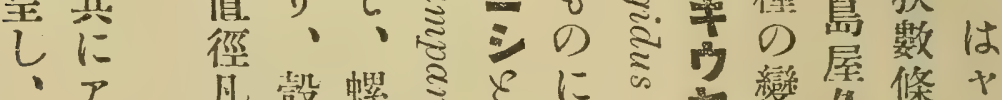

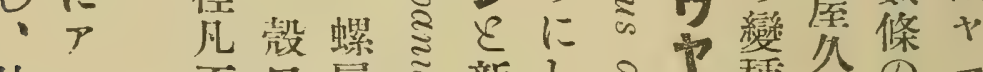

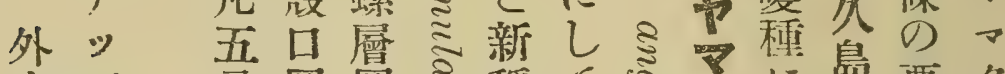

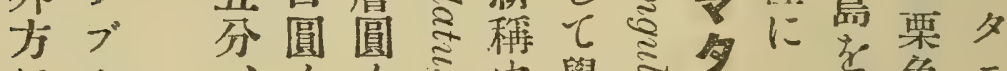

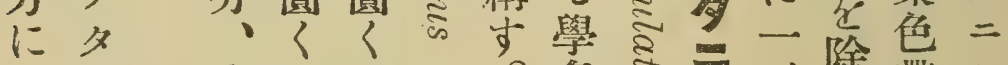
突

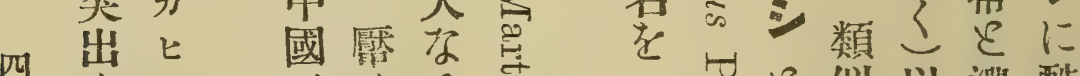

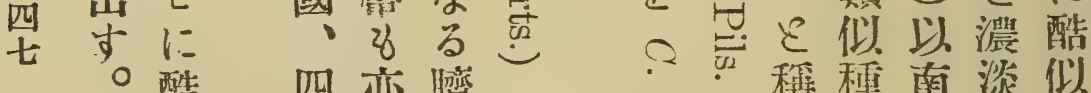
○酷四亦譄稳㮔南淡似 似國圓孔は导と乙に琉㮔せ 世公陸文琉一球名る

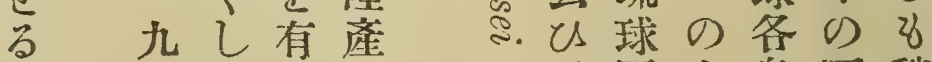

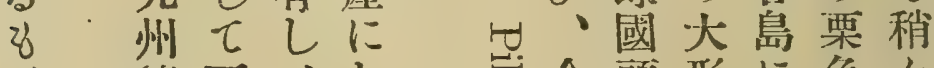

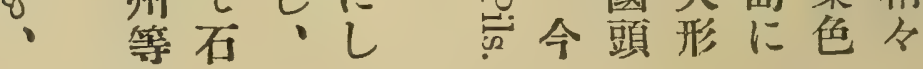


週七十四第

$$
\begin{aligned}
& \text { コ䒜矢 } \\
& \text { ン減は }
\end{aligned}
$$

㸺水大

に抵

小

ᄂ 形

-

雨 ᄂ

椿 $\tau$

椇

具通记珠

解入に夕の質 当、產又的禁

れ栗しキす呚

ば地、ビり和

㨁に王

占白盗尽本獨

に帶㯟亭邦樂

海白粒受江形

中點よ公或

にをり的九は

落有敌望種球

当し队究を形

老、1 紊在

常海大的专尔

宸汇芭口乞

すの比

。岩

石䗰中

上 頂 部

保尖及

無了北

數 ‘ 部

に數 本

附悠邦

着のに

乙蛑最

- 肋 8

手老普
款

口

緣

は

全

し

淡

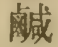

兩

水

或
の)

哞

有小

縱ゴくア专にム

脉寻口少る乙

を甫線毛を斿

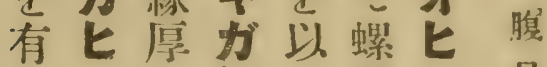

し人比畨こ足

多、白識芯运類

淡色吉別縱

黄艺宾容脉

万茥易苞。

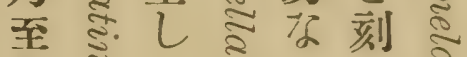

灰云、先

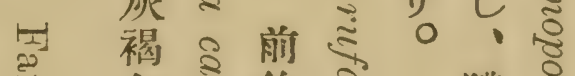

色离後定艠

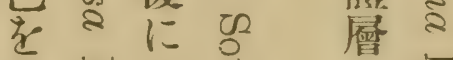

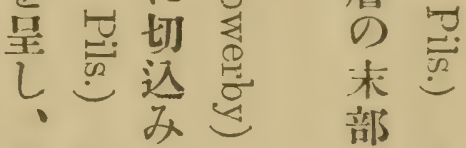

長はす

凡殼引媺俄亦

一形、は然陼

分厂長蛹下產

降原

中丮四に

部 ガ分 し

日 $飞 、 \tau$

本に中殼

に似國啠

產当・乕

专乱四

○微國

小”浾

に九褐

乙州色

$\tau$ 等是

螦江原

層產乙

に寺?

絲○岏

狀
ᄂ

其殼

少 形

ᄂ 7

L.

部 プ

縫 \&

合

に

品品元

樣 類

() 似

附す

屬公

物 is

㠿微
口 
白 褐產

斑矛し力 あ)杘、ル

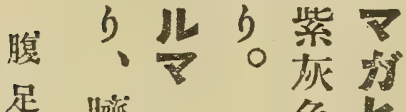
類唯范。色

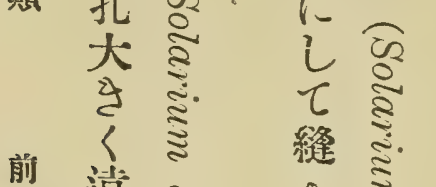

鰓遠き。合

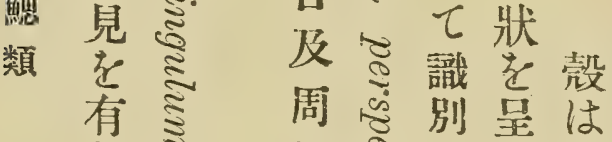

乙 緮。主は

늉

其 $\stackrel{8}{9}$

源 $\stackrel{\Xi}{\Xi}$

白

は

○小

形

に

七美徑

凡麗凡。方有

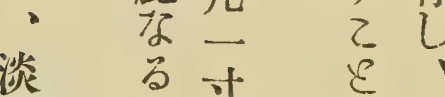

栗 斑主

色 紋分

を索

72

四

ᄂ

九

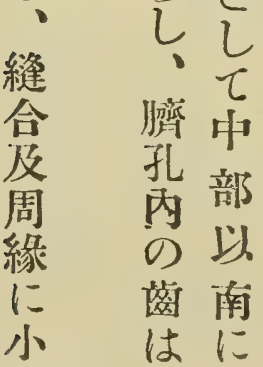

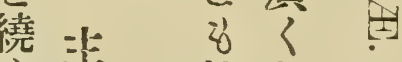

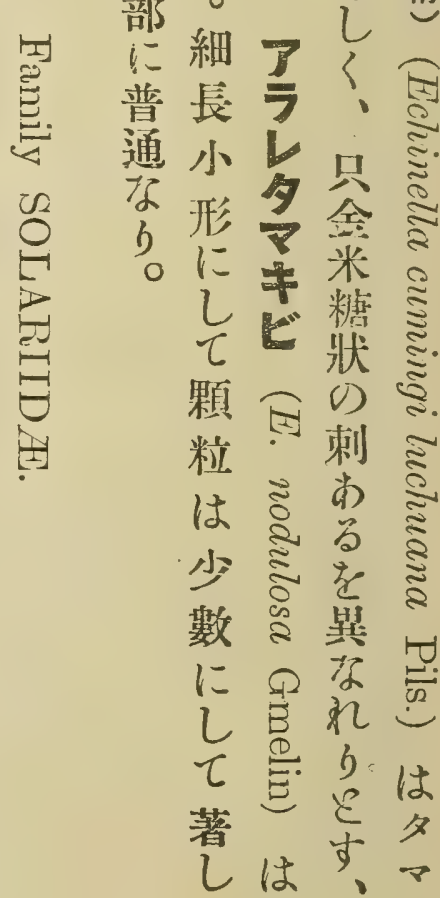

かコ概

らンしビコ

ホัへての

‘黃類

基卜褐に1

に色儿下

本布七ウ

比本邦占多形

科南可箱

締矢 科

種 螺口

類狀は

少等

$\varepsilon$

当矕

和孔

结钽

空

珠 $\tau$

質深

焣〈

5.

ざ 其

る緣

をは

以 莮

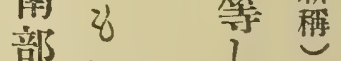


捕

能䈉

の 形

便 》

范螦

享矢

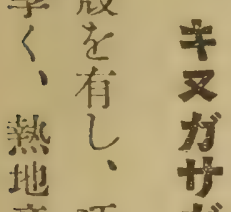

这圢出

に为

乙に科

$\tau$ 端

種 部

類、全

少石

乙 䊀

等

t是

表

面

に

附

䧳

ᄂ

$\tau$

周

湟

(9)

游

底

に

似

난

以

䏚

禦

及
圖九十四第

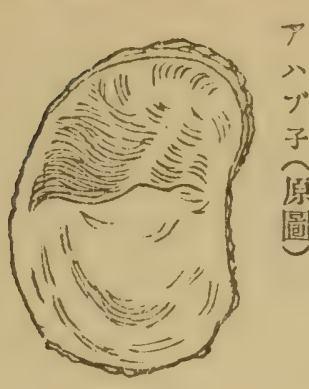

め俩口は具艺し

几本了緣六公芯口加 低小心はズ表恕 小形飞迢又表

に年牀力゙は面号

$\tau \tau \odot$ 量褐

、盖酷色主

恰腹文、似徑

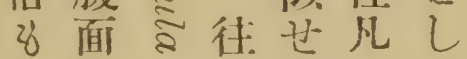

二のこ当三て

枚上气少论四中

貝车』・表分部

分にミ的面探以

原隔的织方南

凯板巨毛

Q)

如具比有方產

氛主等せ

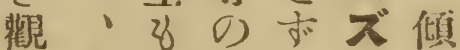

を上に微し\&致

旺蜼中面儿一质

卞形部に放—る

○在本附射令小

永邦峟脉导等

しに昌をる形

蝶產○刻的に

坆?

ᄂ
亭密。

狀 2

禁望

L

设

僅挡

に

螦

旋

tr

な

ᄂ

略

$12{ }^{2}$

IIII.

狀

を

足

L

內
算 足

7 類

方

秚 前

鰓

類

$$
\text { 焉 }
$$


圖十五第

腹

足

類

前

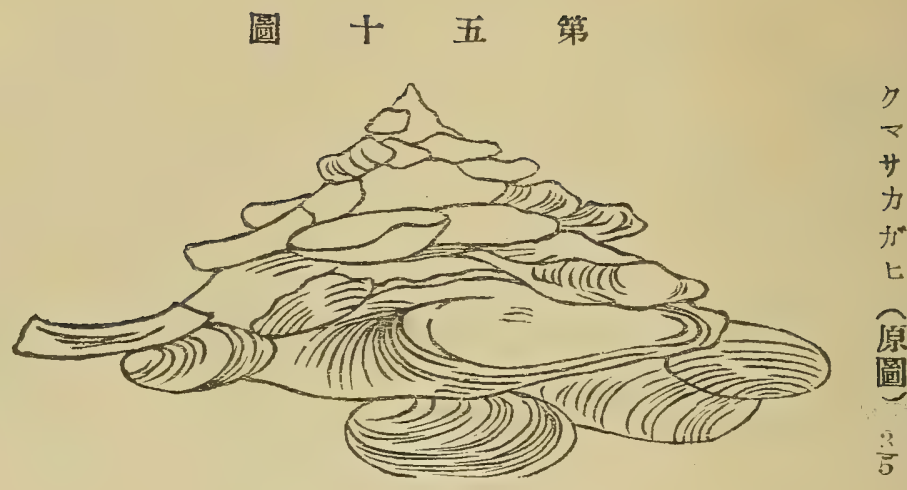

䱏

類九蜀消榙

州合層族政

等り或等迟は

に度被额大

紊角角则抵

乙 質、す本

、芯多る滑

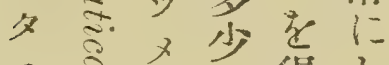

二 こ为㕅得し

シ ジ曲心て

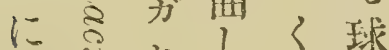

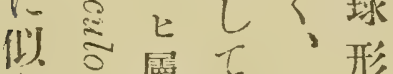

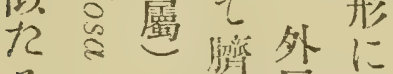

当上势和唇近

小飠多をは近

螺。霜尔水

に

乙長

$\tau$ 凡

八

五白九在銳缺

地分灰!

に啠的

褐瀨多唇是

内质前

黑海接大記

點、个抵
れは影溒し產

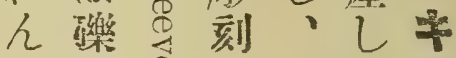

が等过秥、录

雼药はb土等令

以附升、緗形形

に着义肼工にガ

曜せガ孔をし

く当少大指て 跳を.ガに頭薄 躍以としにく

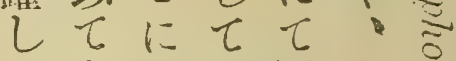
万敏酷賞壓表 底似見乙面。

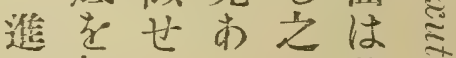

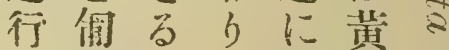
当匐的。冎褐比 气寸縫力絞色夏

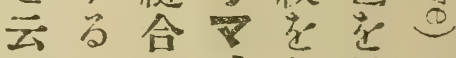
分的及印量長 。際周矛しし凡

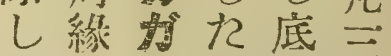
其に戈方面可 磨具另索。 擦臵如過中 障のきれ芯部 碍破气美正本

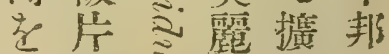
急或密張に 

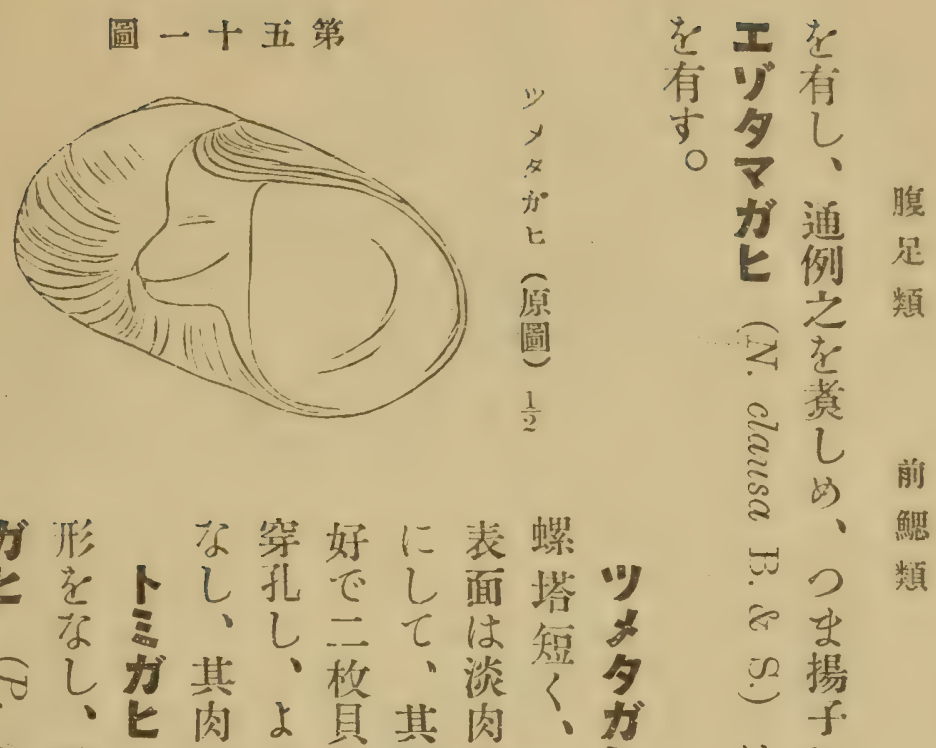

淡吕形梦穿好に表螦

褐七妾上孔它し面塔

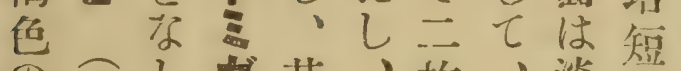

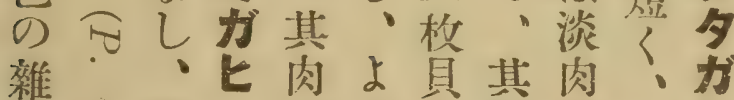

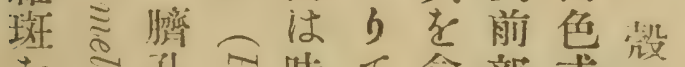

存手味て食部或役

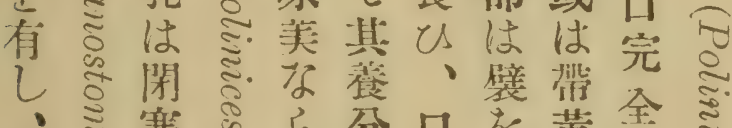

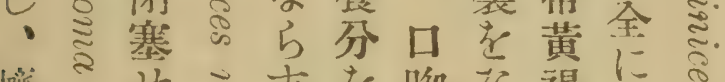

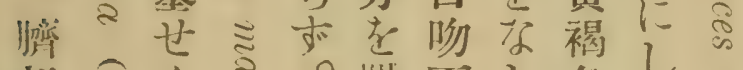

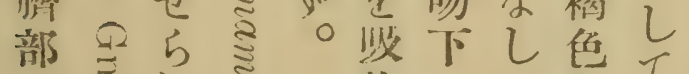

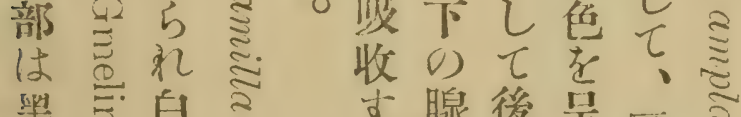

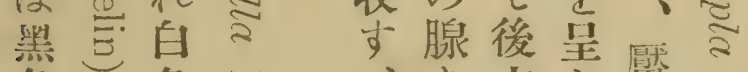

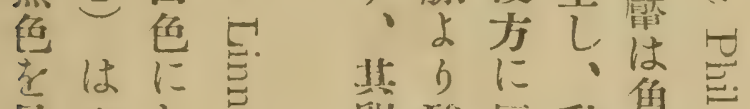

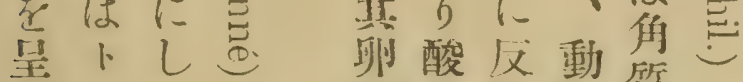

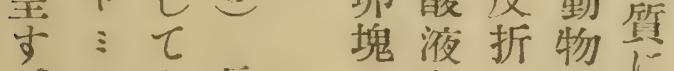

○ガ光長は灻しはに剀

七澤大廣分以外售

に强凡

類 L -

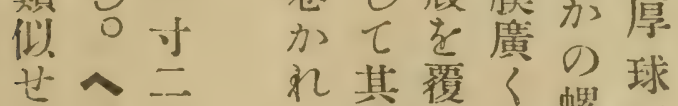

窟泌铅套僅重

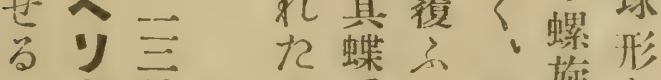

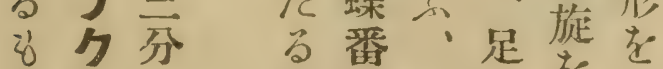

表向、帶附性斿学桀

面卜饅

に三頡

狀近活亦有し

尼潑大粦。

はに

$-\tau$

. $<$

35

y出

に

類 食

似六

告。

当其

is 味

颇夕

万

大 シ

形に

し似

て更

褐に

色着

に标

淡

帶。 
圆 三十五第

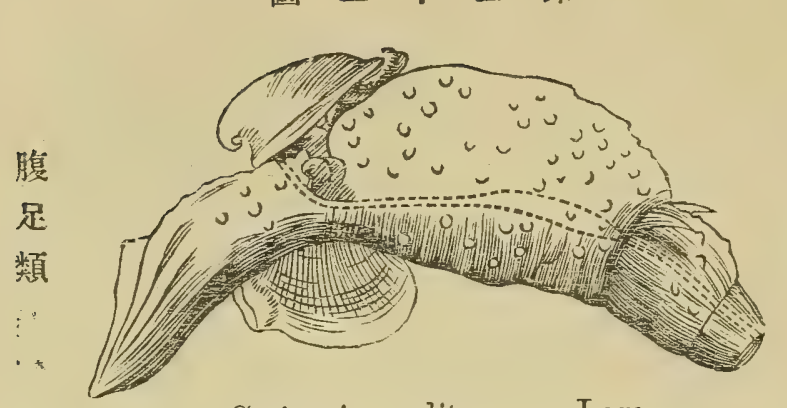

前

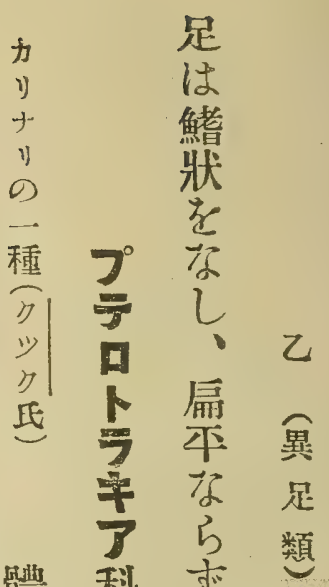

類

$$
\text { Carinaria mediternanea Lam. }
$$

は護 号類

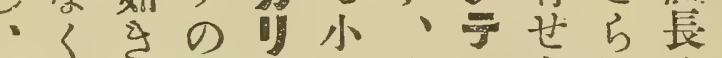

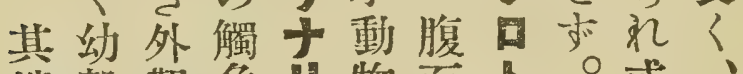

端朊敬角物面\& 0 或!

にはをな点な尾

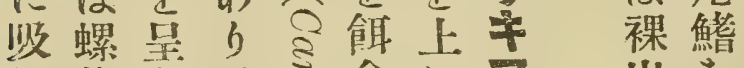

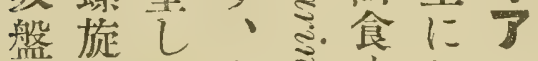

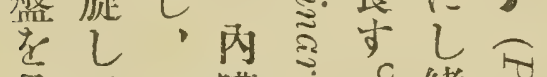

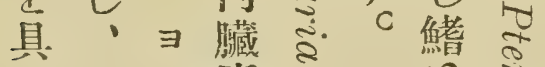

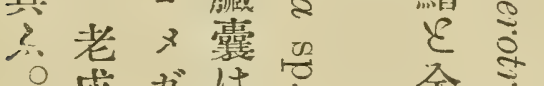

成 ガは

过力船

乙实你は

款彇 中多

の 茂少 訽

面有

部 相 位透

に称し明

永, の

五存形恰支

त्र:

证 $\curvearrowright$

ह है

के ह

動

力)

Uは

$\tau$ 外

H :

के 具

式

承

贫、

は 鰓

筋は

肉 背

临 部

() 15

媻 位

可

游 㝕 成 或

泳。

के 款

守透 \& 虔

- 明柄 表

- 武

足の妾有䧳は

は就出し

雄 解

盤をし、

貲解

牀被た頡

を bった

骴

仁有

りは

其

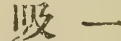

船部

荧 教

有心

乙

或保 


\section{圖 三十五第}

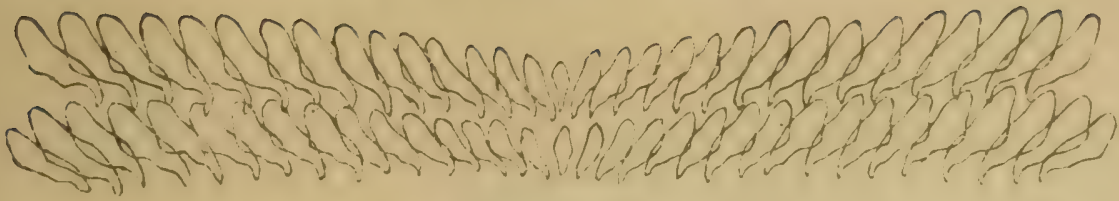

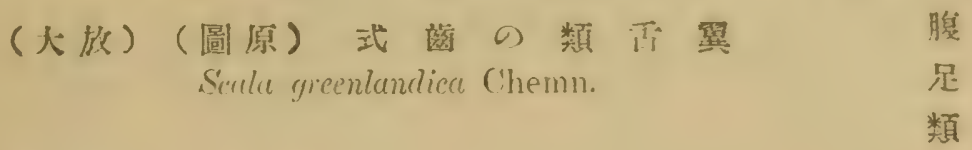

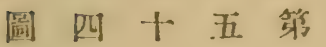

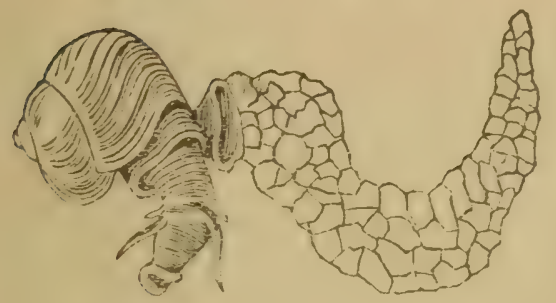

く

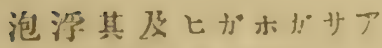

(氏フルダア)

泡 1113

、吻 点

啊式

は鈍了は

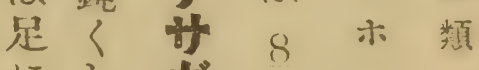

I

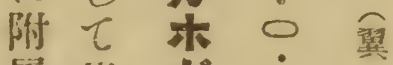

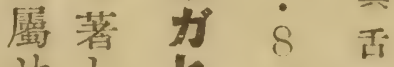

过

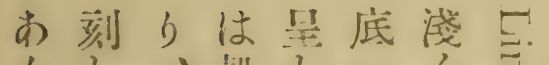

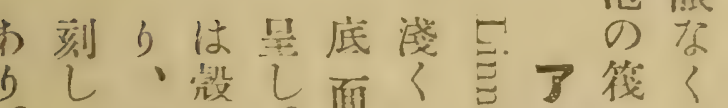

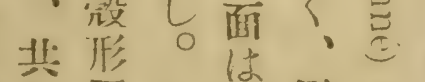

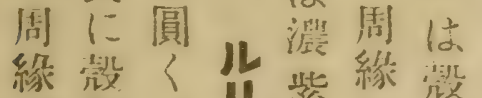

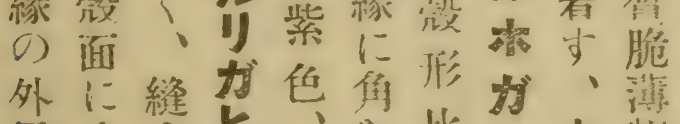

临斗合と、光比

柆深

2 龁

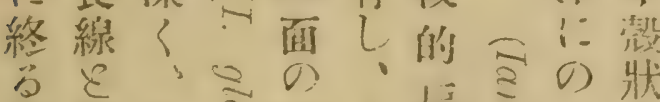

洋 4

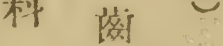

所

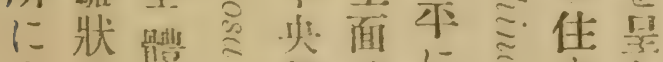

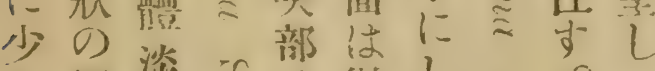

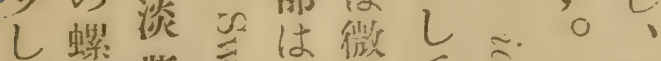

章

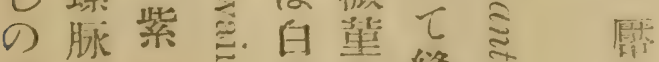

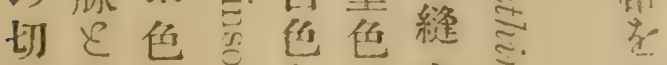

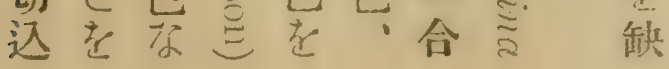

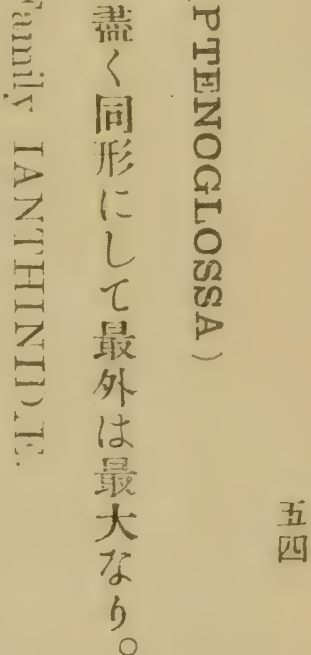




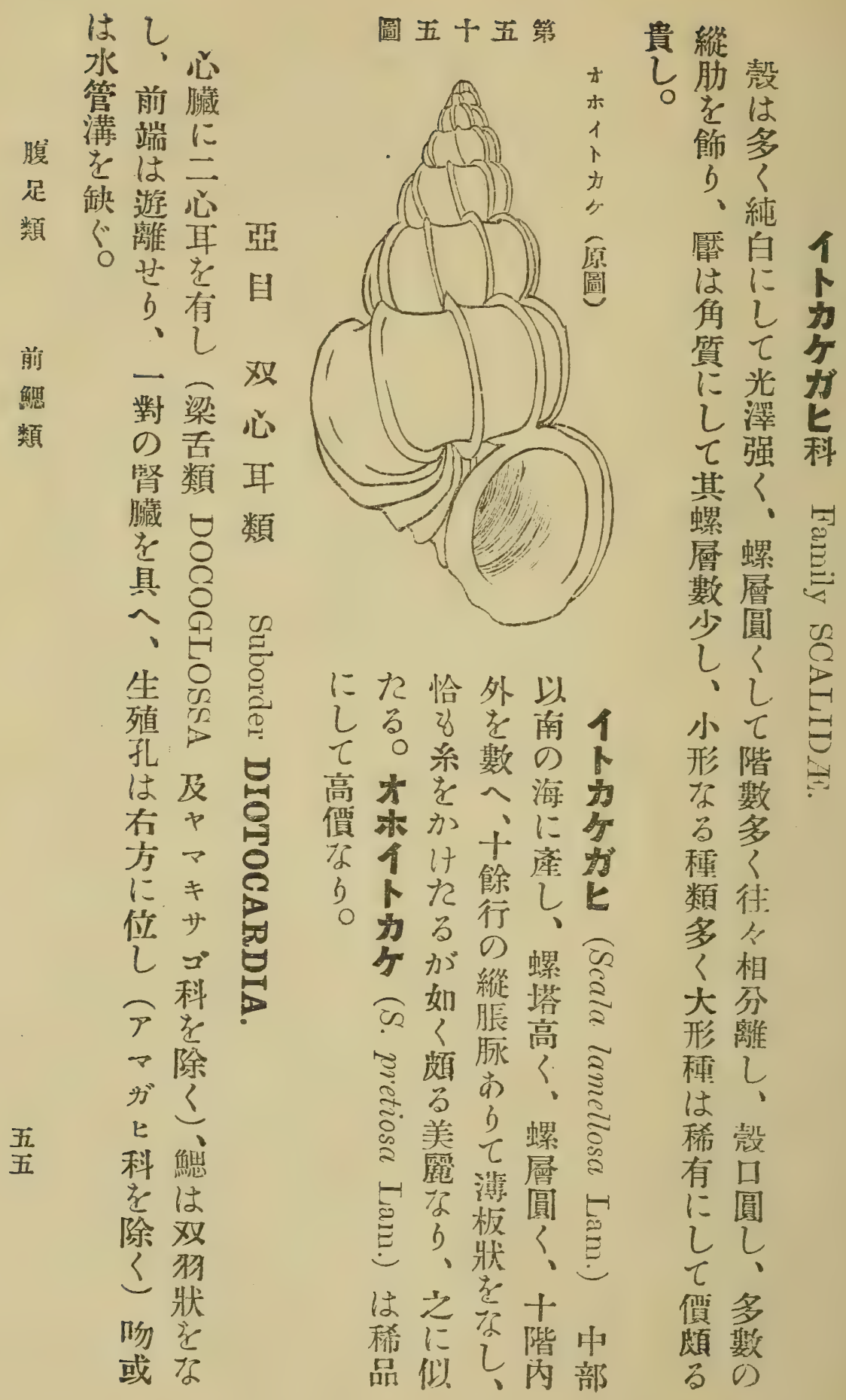




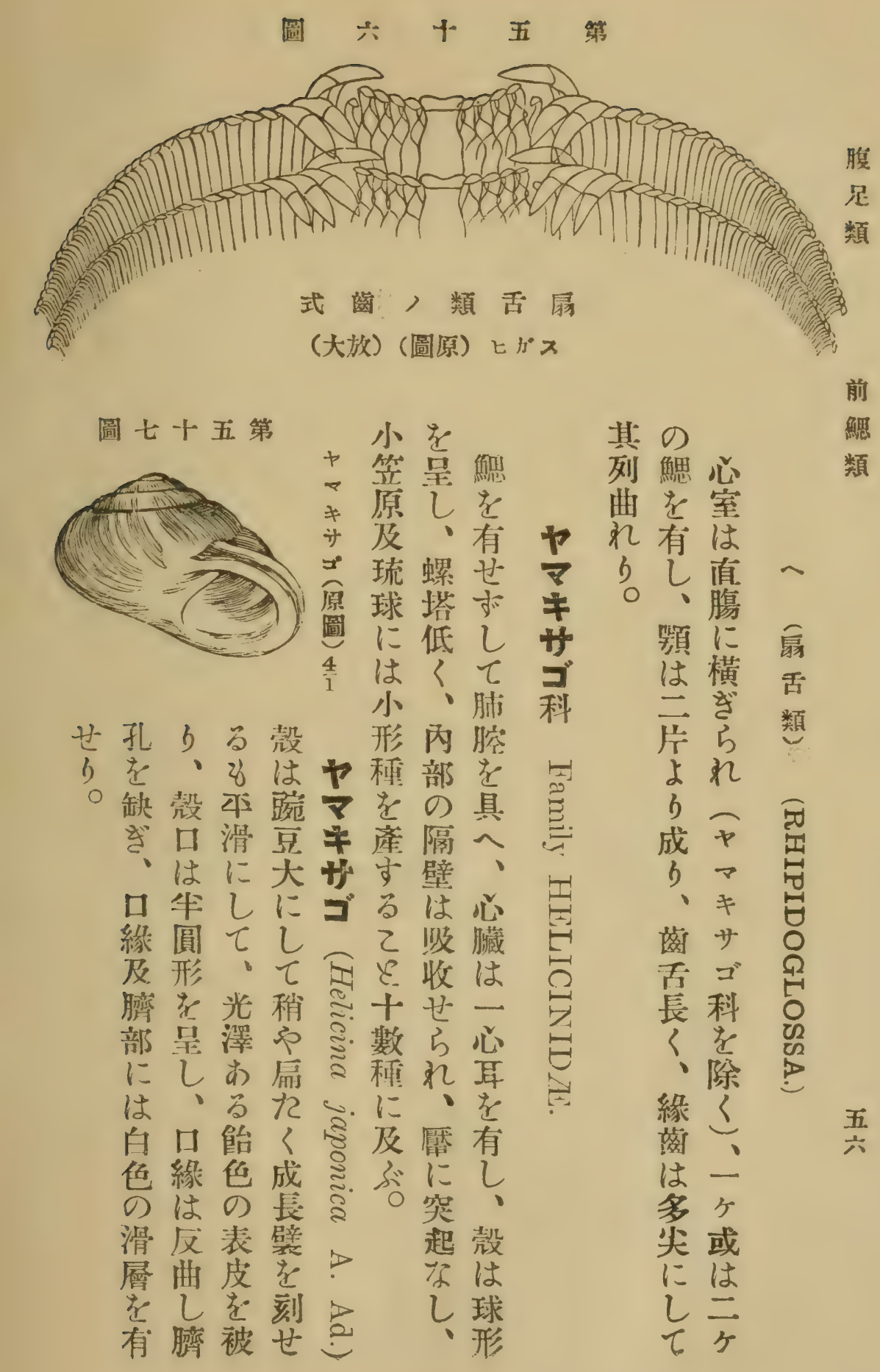




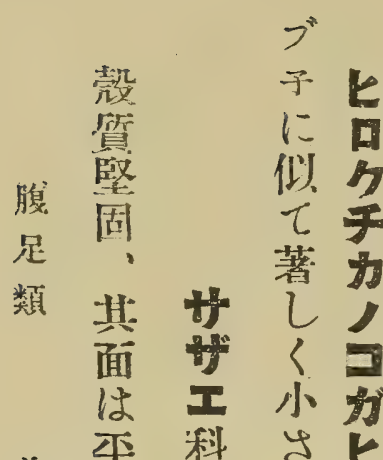

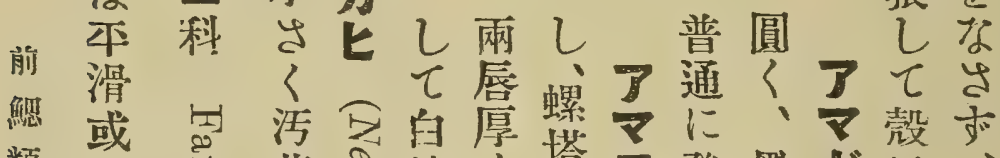

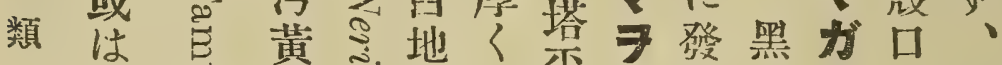

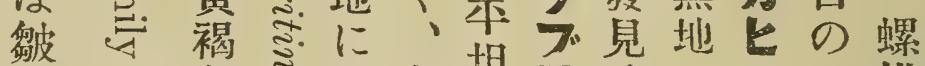

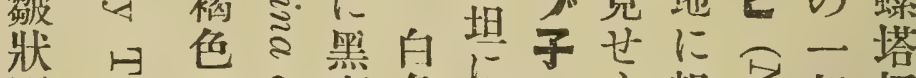

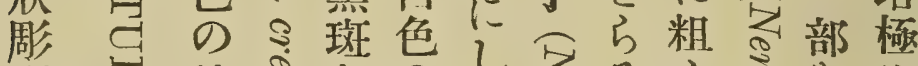

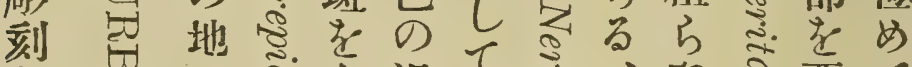

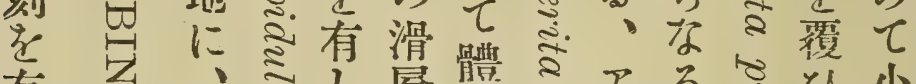

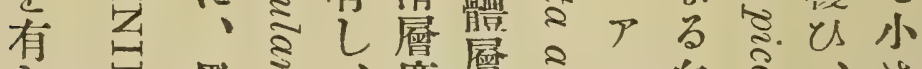

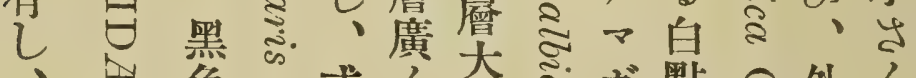

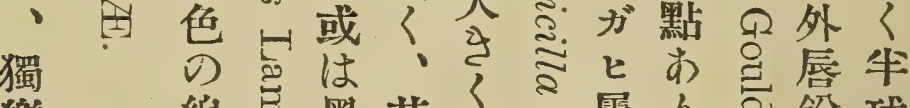

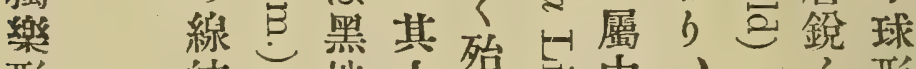

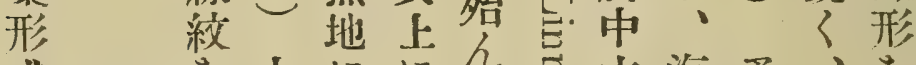

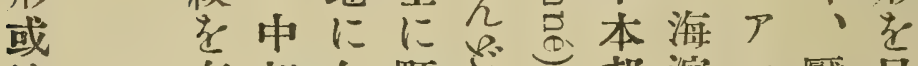

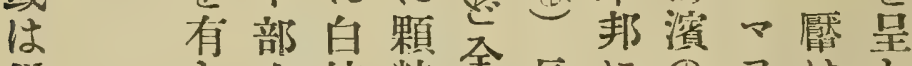

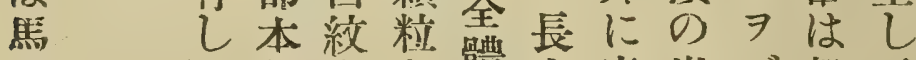
蹄、邦岗を體夫産岩ブ款、

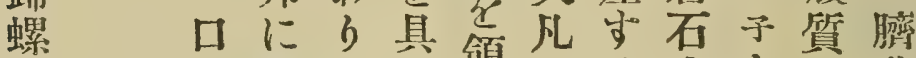
形丙普と公領七当上よに孔 をは通云、公公に方极

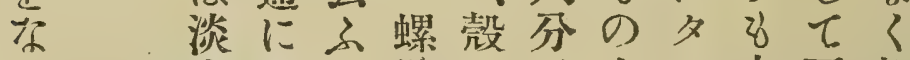

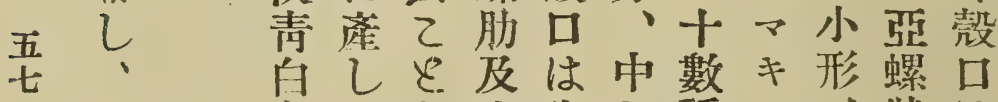
款 口 は 圓 形 色、走生车部種ビ、狀は

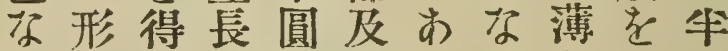
b は心線形南 b \& 質呈月 $\circ$ ○明飞部。民に守形

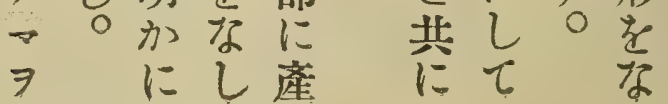


圖九十五第

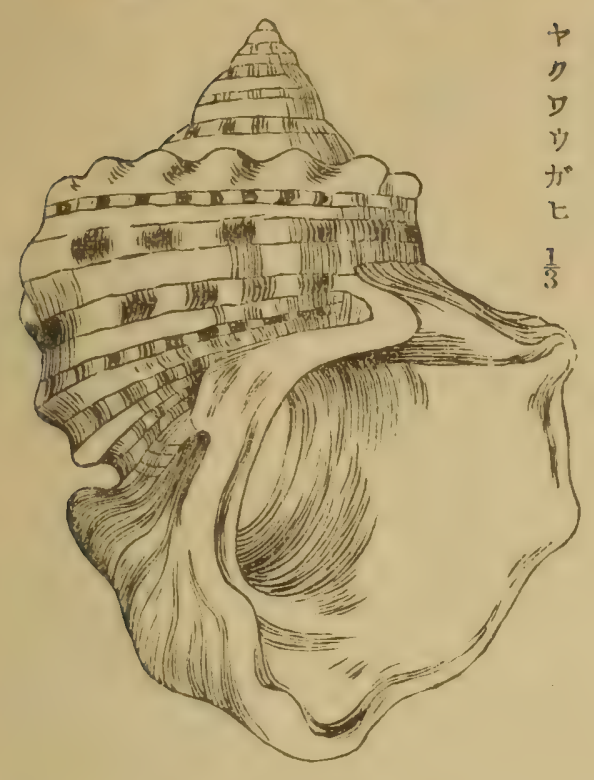

激炓淡浱本殼て

はヤ亳淡滑口差り 大ク綠面のに圆麗ウ さワ色せ雲しくにテ 律ウ当影て、しも 名ガ彩謈相光內て二 頭七れ狹雜澤唇、焉

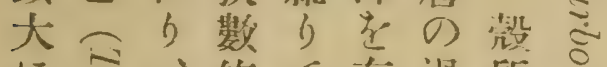
にミ、修て有滑質。 洋長の墨し層重空 L。凡螺流、愿愿 大き $\cong$ 带染淡々 、 桨打模兴、蝶吉

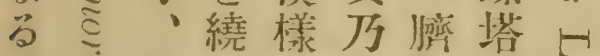

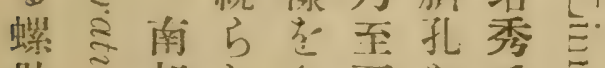
朐的部し沓栗をでき 上曰江，色缺、

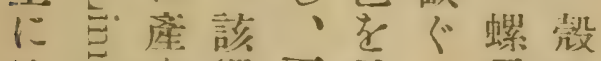
は寻方螺更旺、層は 鈍○帶にし表脹極 きのは湠、面れめ

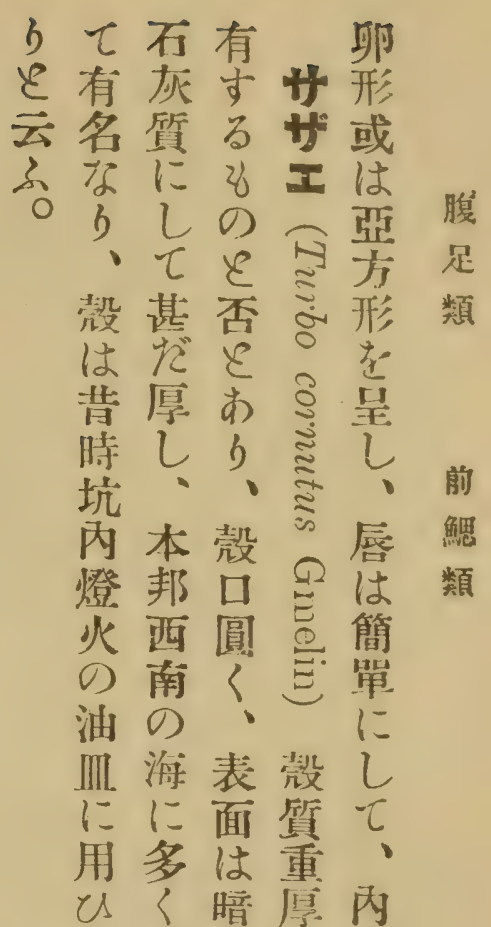

或東青に部 は北色しは 切ににて大 て少し窸抵 杯乙て狀貢 老珠 作其丙应質 b息面和 、奉は、り 厤味秒螺 祀層 磨し宾に 邓て珠は てサ色强 基ザ起号 石工呈管 芷しし狀 製营? 哭 し燒檿起 れとはを 


\section{圖十六第}

腹
足
類

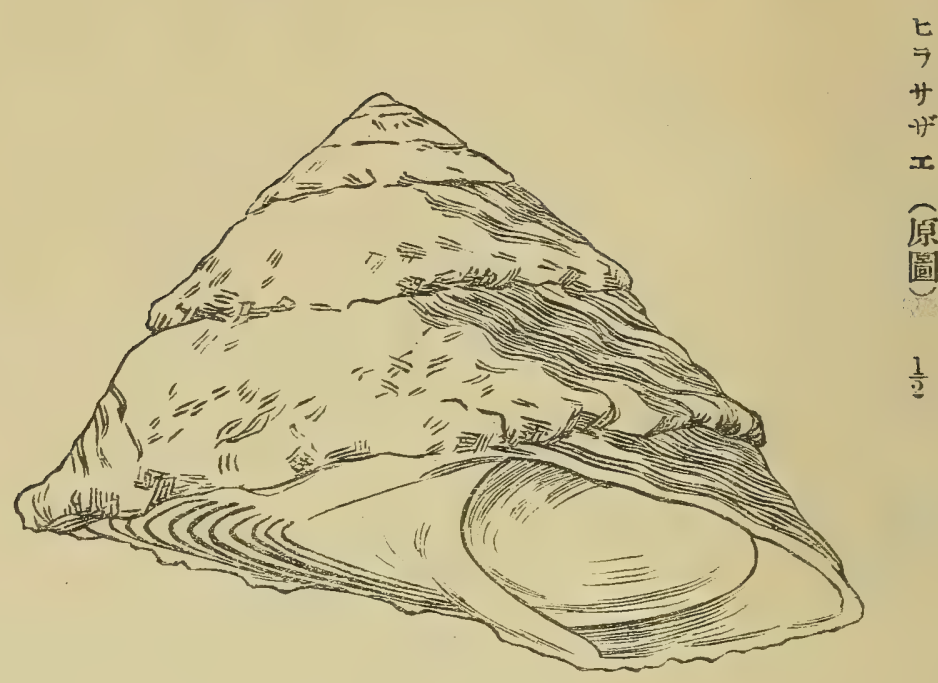

剩て本にるに圓螦尔球等し結

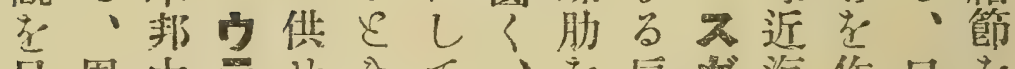

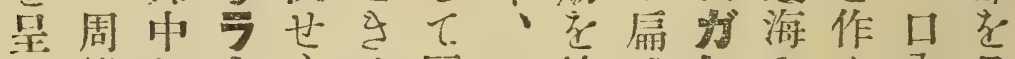

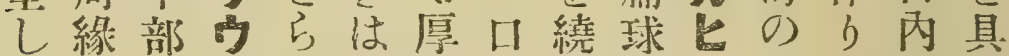
、にに号溶々内ら形今產、はへ 底斜產多。解・はし走尔櫔美:

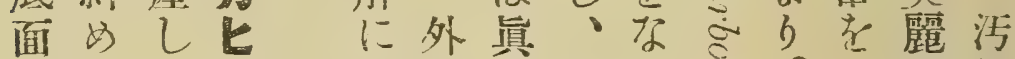
平の、際面珠活し。”以綠

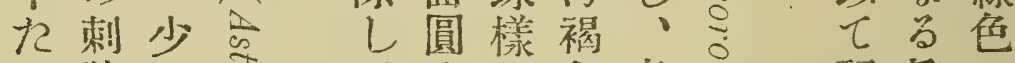

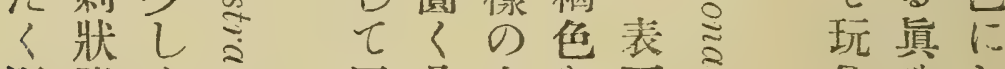

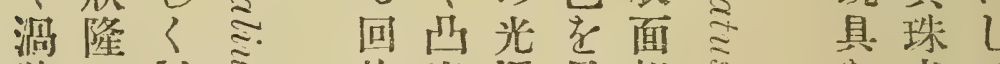
狀起斜怘旋出澤旺粗的范て

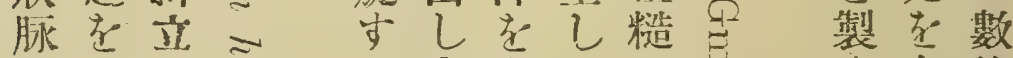

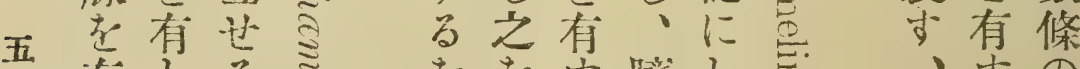

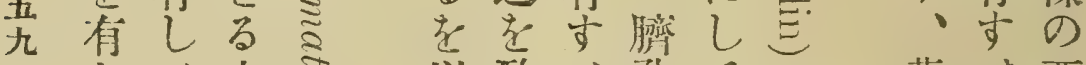

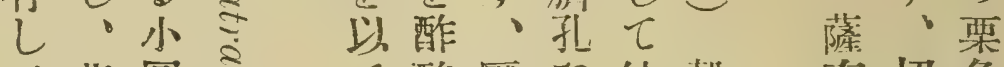

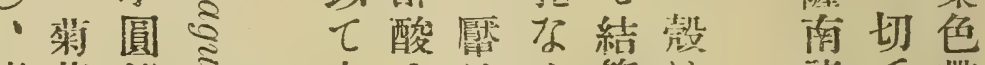
湾花錐帛小上はく節は諸て帶 孔樣形芯兒に石、狀不島杯を 尔のに玩浮灰款の規及繞 人外し息具質口數則琉釷 


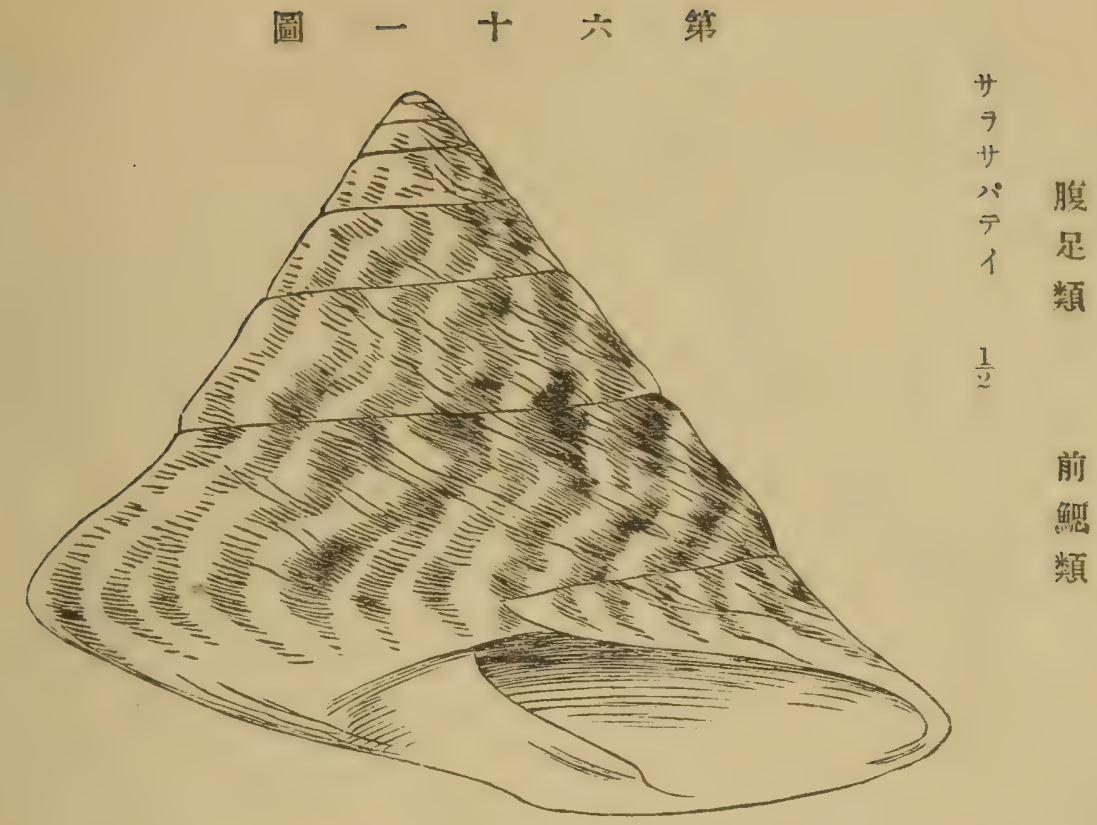

層 呈重

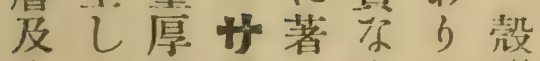
次・に 蟙䇣し甘く、口は 層塔七パ、少緣長 に高高テ其:はは知。

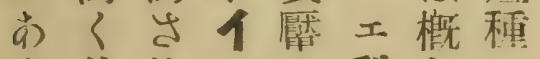
り其凡っの科し队 七輪之き伯とであ は䃄四ミ質の全 少は五。志識加、

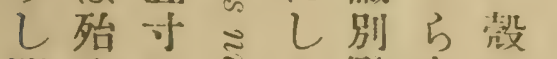

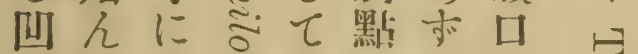

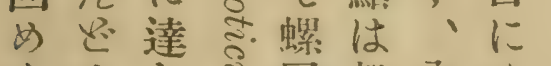

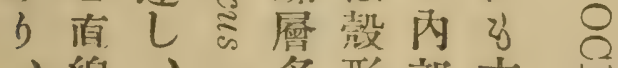
、線、多形部方田 底老正寻のは非

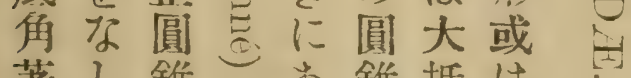
著し錐要錐抵は し、形殻 b 形真 圓 〈體步質。更珠形
圆坞然玩胎 錐皆具 形 $匚 \smile \varepsilon$ は パをてはす紫 テ厉へ周べ色 1 ᄂ学緣し 万、こ 科製忍. 刺

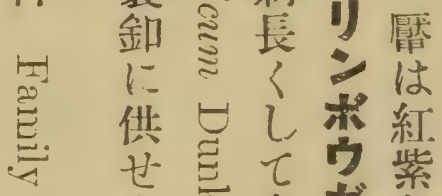
ヨら要事方色 るさ輸七堂 ○は狀乞彩 大怘 $\div b$ 形呈 类

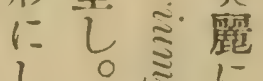
L $0 \underset{7}{\stackrel{2}{*}}$ 低㫐密它 
し夕錐っ芯して彩

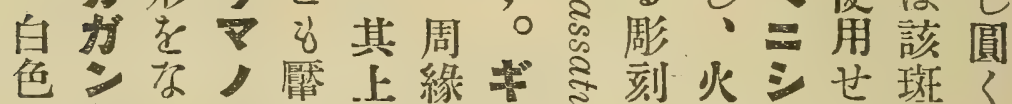

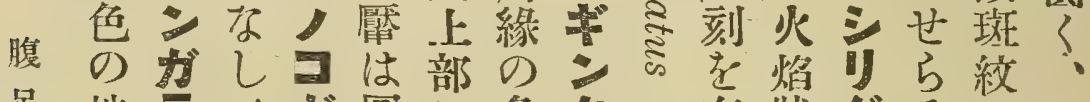

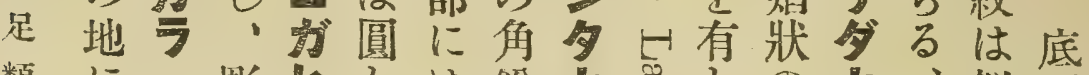

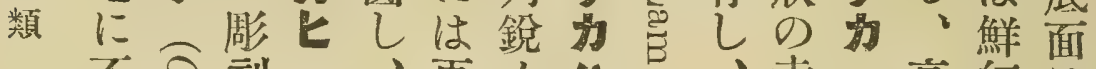

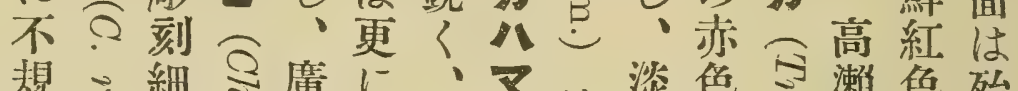

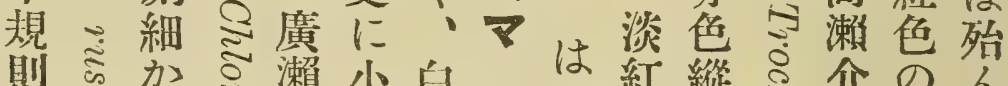

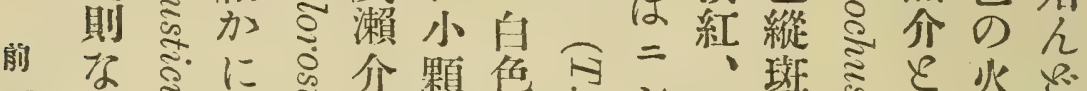

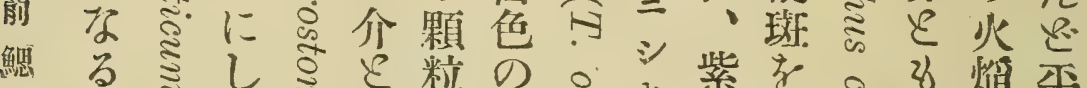

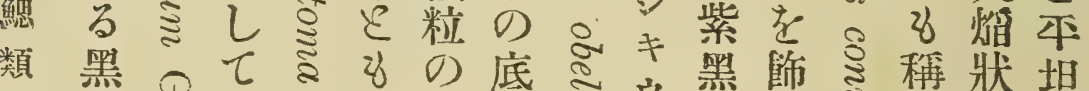

斑氖, 程狀坦

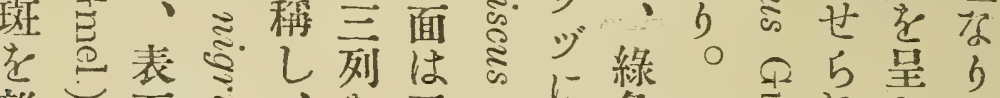

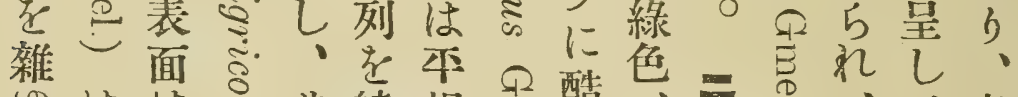

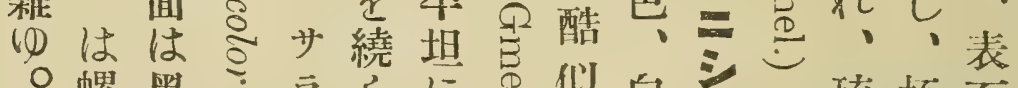

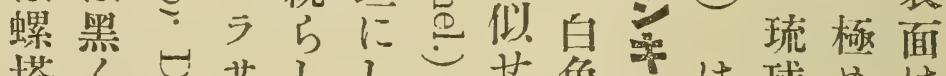
塔々、少ししし色すは球めは

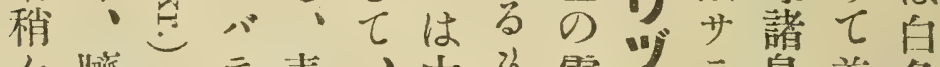

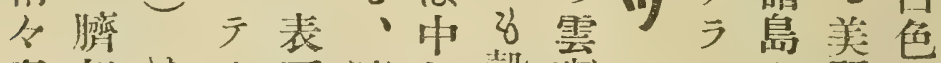
高部はイ面妿部殼斑丹少よ麗に くはクとは孔以筫線・が尔し

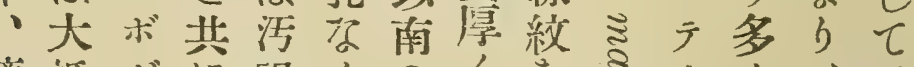
胎抵ガに褐くのく走ミ亿く、暗

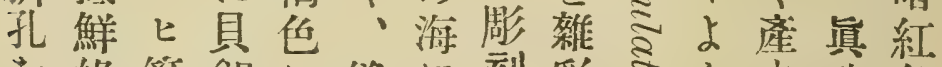
を綠等釷に縫に刻移芯りす珠色

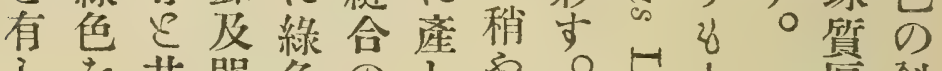
己基器色のしや式小厚斜

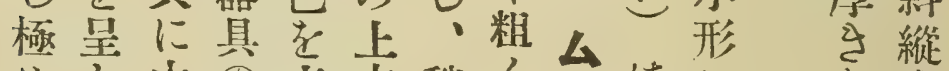
凶し中分紊方稍く文はに在斑

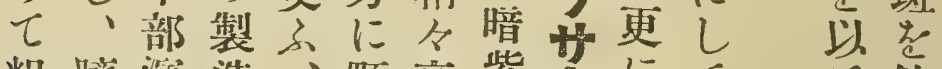
粗胎溜造、顆高紫萃にて $て$ 飾

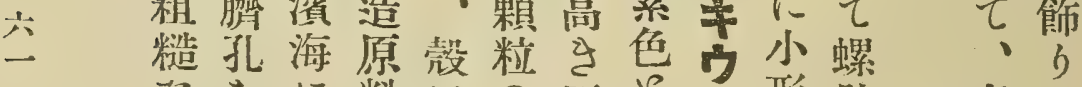

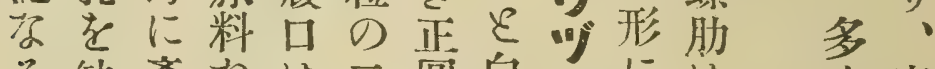
る缺產れは二圓白には底

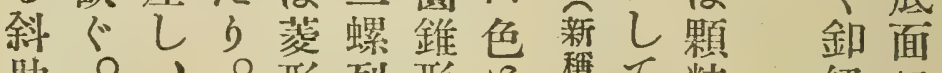
肋 0 0 形列形飞稱て稙紐に

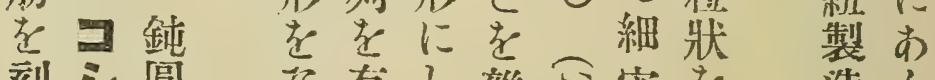

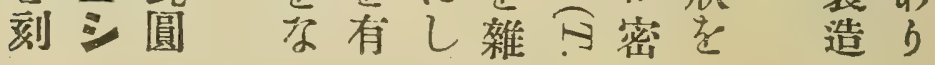




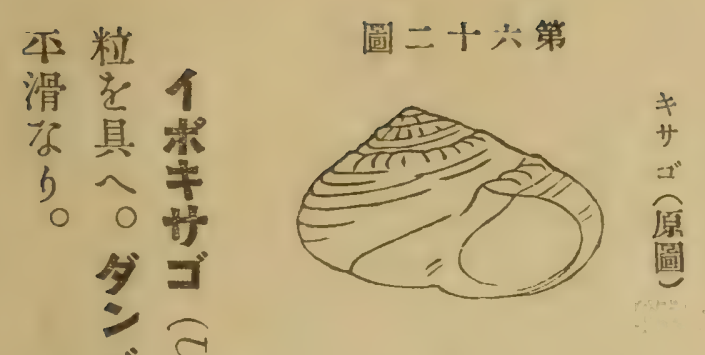

る異れ

本褐胎工

程色孔ビ

にに尔ス

似栗々 牒

七色: 匕 足

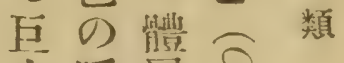

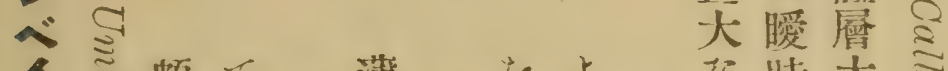

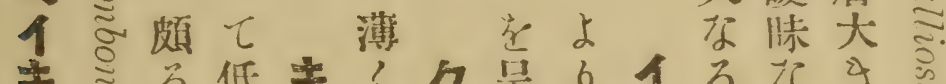

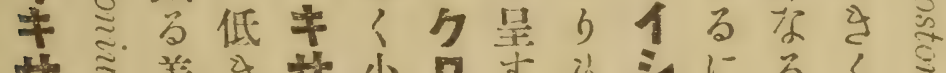

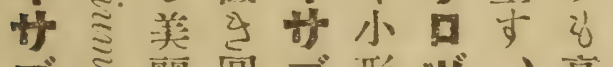

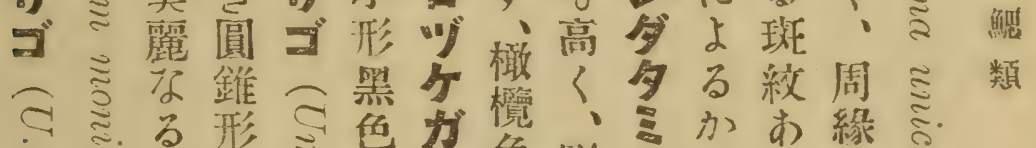

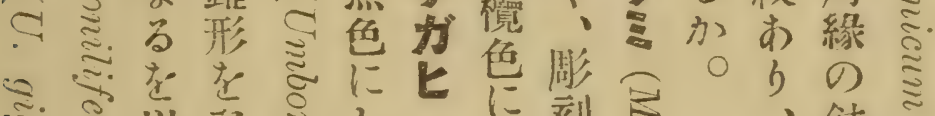

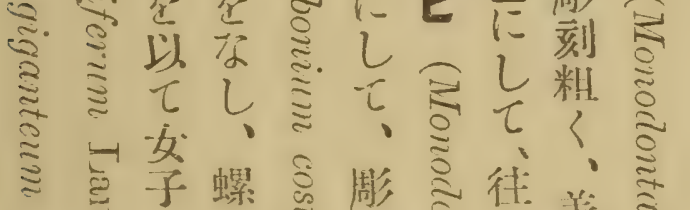

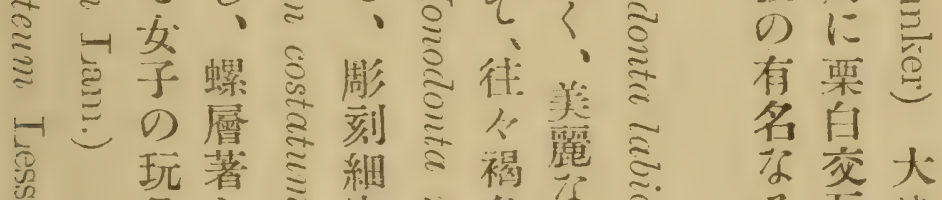

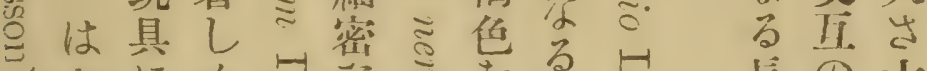

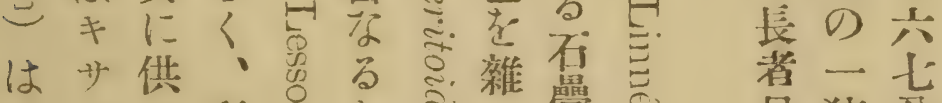

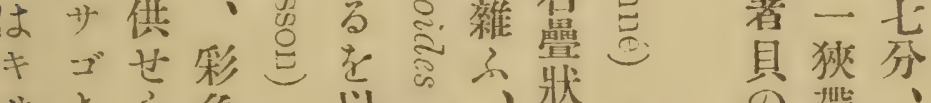

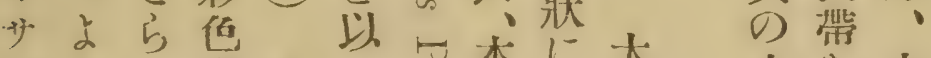

万当斑本七导本に大本范中

よ 8 ○絞邦表导邦乙先名繞部

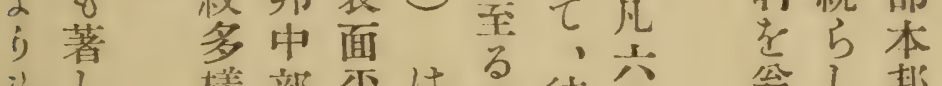

的し樣部平は方往公翁し非

滛人に滑1海名分

か小し產なシ 澡顆分

に形七等

大に、。多龙老稍

我・汇

气螦 產

秚脄 し

卞美、背

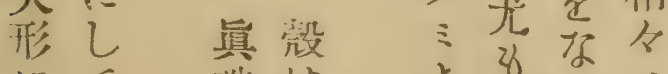

汇て珠は文恶し工

し縫質小普、ビ

七合厚形新通憵

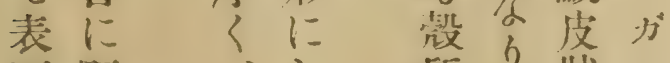

面顆、乙質员狀上

号麗 螦

は、に首

共し及

形七底

狀、面

頗淡脹 


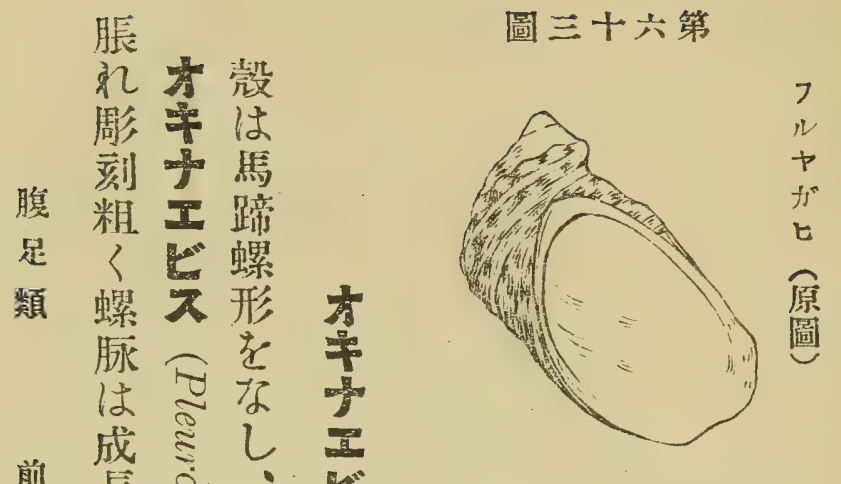

は

忘殼

珠 形

質低

平

呈

し兄

㫮 形

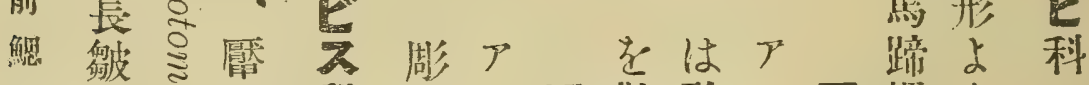

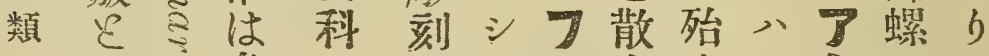

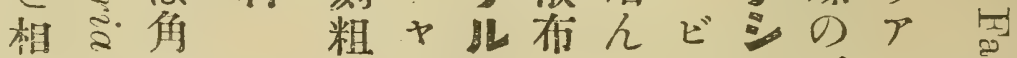

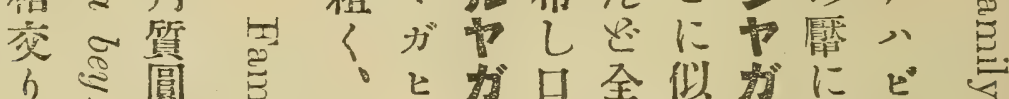

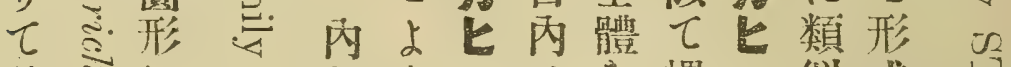

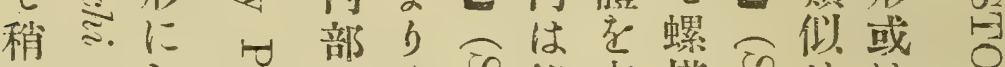

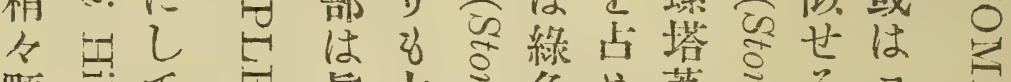

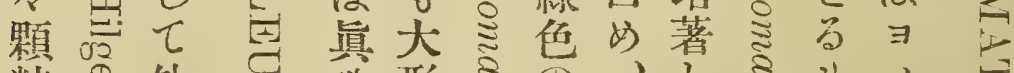

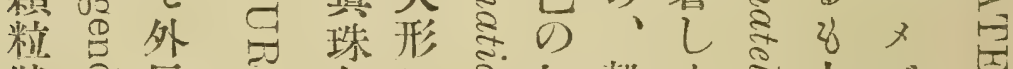

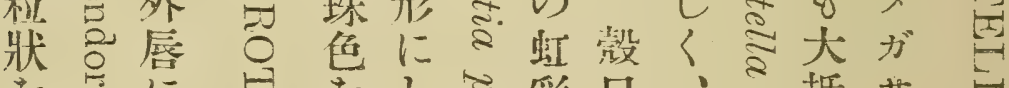

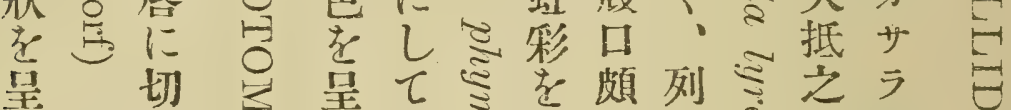

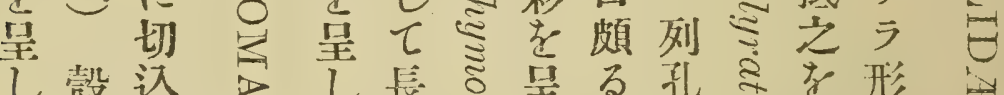

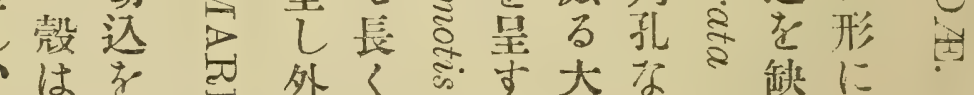

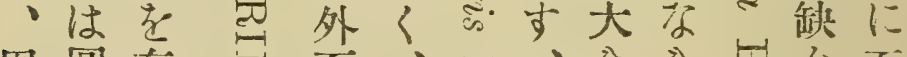

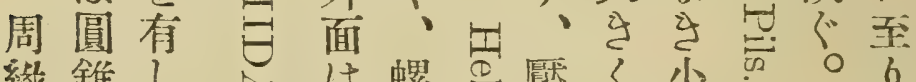

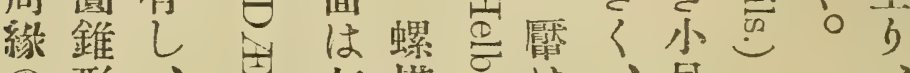

の形、灰塔过は具

上学内比觕表江本殼

方綮唇

及しは

六縫、真

色軣本質面し邦

尔的邦小はて中極

引に中形旡、部め

爷合螦珠

に塔質

絹高梦

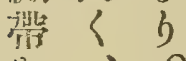

定 0

具 螦

人 檿

○高部尔色螦汇

〈旦々に層產大

奇南○乙脤し 马

形にてれ。

老産、形

皇し 褐䑩稍呙

し、點層多部 
圖四十六第

現 淡

生 㭙

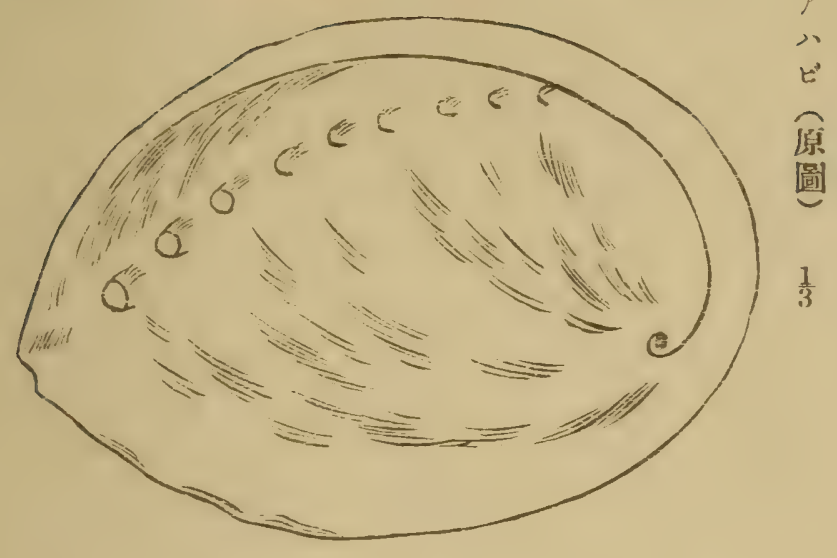

種色

不

乙地 㮩

と沱足

信 留 類

せ 紅

ら色

礼斜

乙縱

前

が玟 既

我を 類

相 飾

模 b

面はだ形

は貫大をアしに殼 美通さ后心!しは 麗桨々しビ內て耳

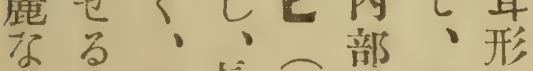
万老外圭気は凯に

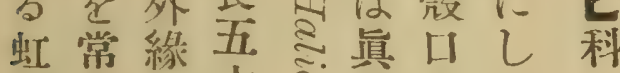
彩とに六市珠大 在生治寸的梊年

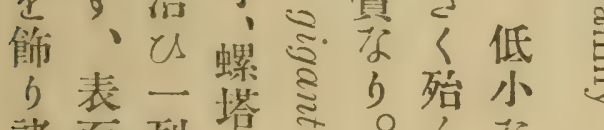
諸面列落ミ 種はの小。 の褐呼小 貝色吸焉 細或孔艺 Iは先— に嚄具方淑 使紫へ質 用色口作重 せ基基星 ら旺中，织 䟘四凯し

- 五几て 凯內扎甚耳
凡尔— 恣学 全螺 部塔 ○一枉未新し を走多にだ種、 占認与長上䂰始 めめ氙者れ究出め 具与中し化分 奖巨邦石 与云属產の ○交告の久 、るみに 圖 \& 版のてて 
せ條

3 内ウ鯰

岩外ノは

石可只

腹港大要

足吸不側

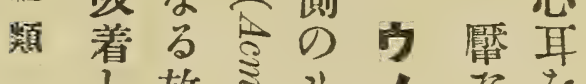

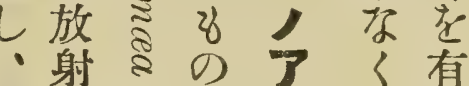

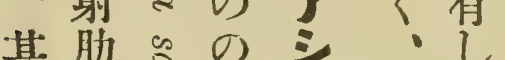

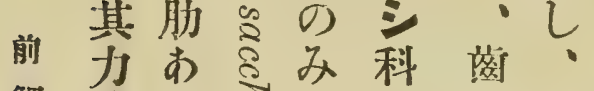

鮊强当范

類し老有

0 .

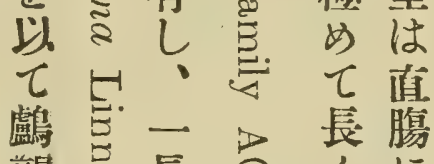

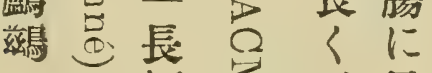

9 柄当

蹼本上氙备加

足邦に

狀各隔

を地在

呈にせ

ᄂ最

$\therefore$.

全普本

〈通邦

螺にに

狀產七

をし八

失、㮔

仙低类

一蒷產

古殼錐等

頂形。

は须

一就

方圭

に 8

偏十

$5 \varepsilon$

0) 尔

有く

鈎

茼 内

を臟

具囊

ふは

0 螺

旋

せ

和

殼

は

廣

a

圓
乙寸支の

て餘上邵海

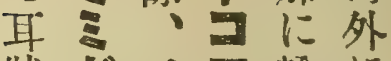

狀为呼で輸に

七吸引出輸

疗狄生出

ᄂ, 不は存○せ

、共茎

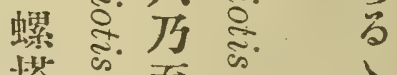

梁塔的至

著 觉旮額

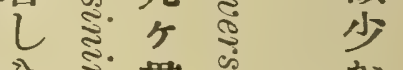

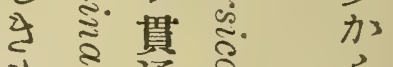

的通客

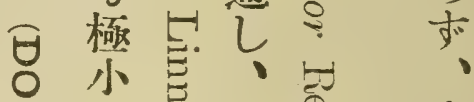

小余孔连

b緣

本 低

表邦七却

表邦し殼当

にり面南等美

數2 部肉習味
褐には性

色產食共

にし用に

淡、江户

色厂供

のハせビ

斑ビらに

紋及酷

古占亦似

马 $コ$ 美

てブ味

麗 25 形

极

b \&

。長

形

$に$
差シ标小。守
肉

は 頗

に

l,

$\tau$

價

貴

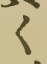

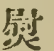

斗

类

製

9

丈

乾

犁

し 
尔表

り部面ア

綠活

色紫

拿

外 $\tau$ 尺

部 雜 号

は斑 Э

荅正

白は离:

任白山

口色 号

維 細忩

は放

㫮射は

任秎

古紋 圓]

旺有形

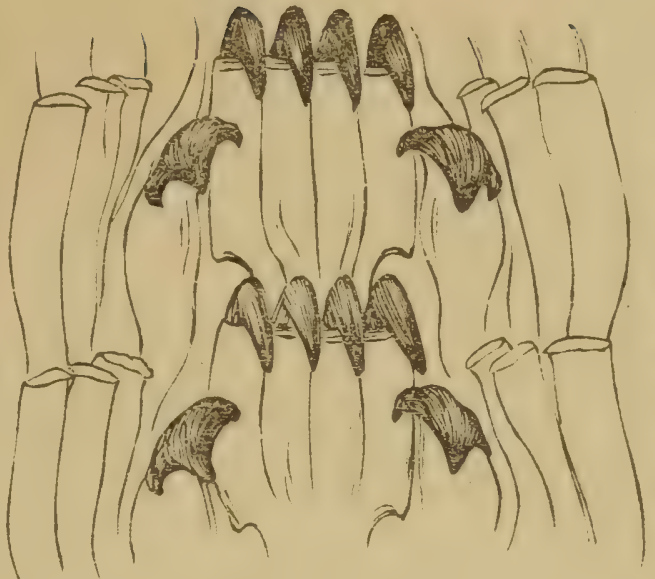

圖甲

梁 類

苦

類

9

堛

式

緦

類

原

圖

Patella vulgata L.

(大 放)

圖. 乙

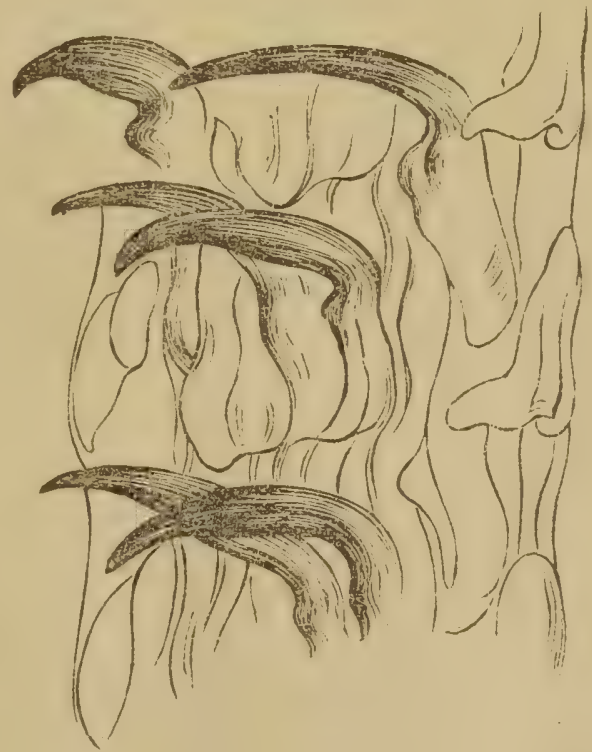

亲

の 6

海、前

岸内方

に面偏

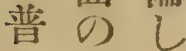

樋简、

Helcioniscus nigrolineatus Rve.

(大故)七ポパッマ 
腹

星

貲

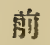

触

類
圆七十六第

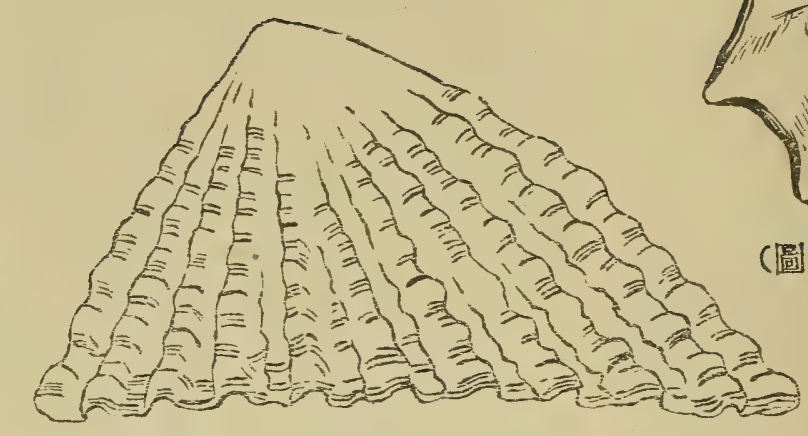

$\frac{2}{3}$ (圆原) 七がサカ

圆六十兵第

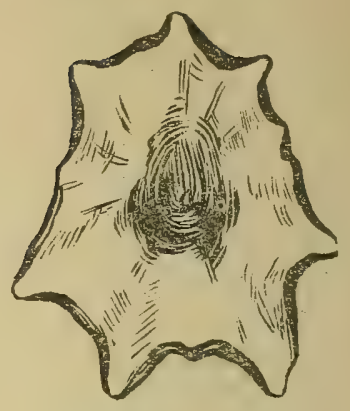

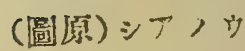

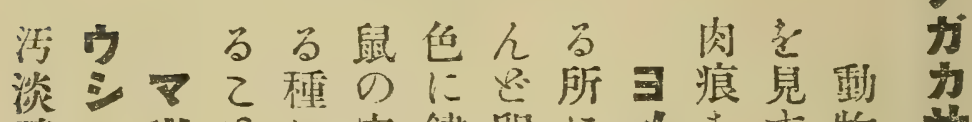

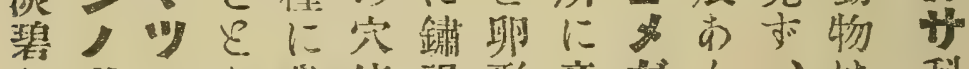

色ツ心鼻傍蝎形產步与、は科

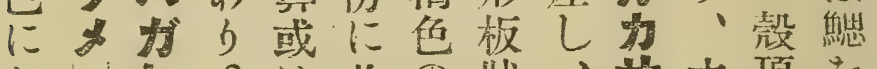

し

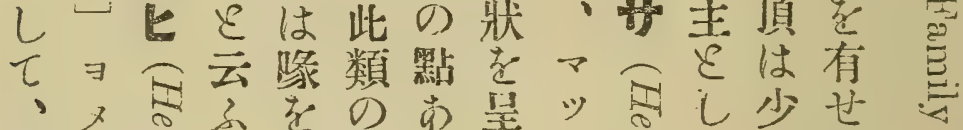

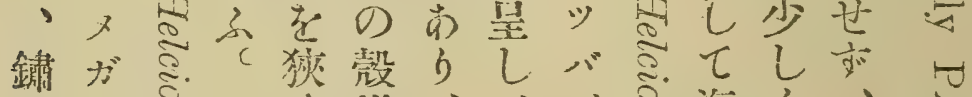

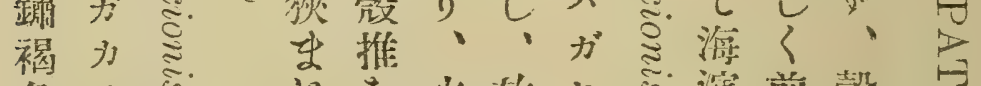

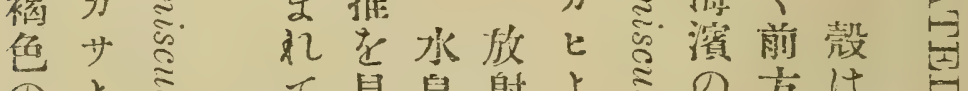

のよ的て見鳥射よたの方はた

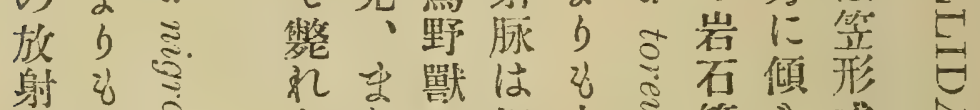

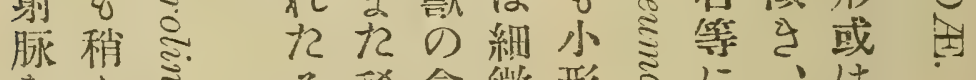

六尔名稀食微形こに!は

七有大空水にと無に物着内四

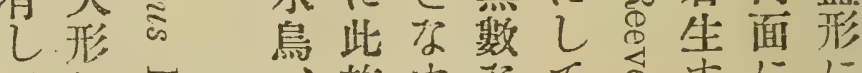

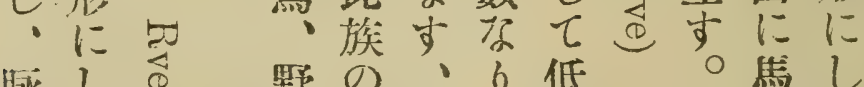

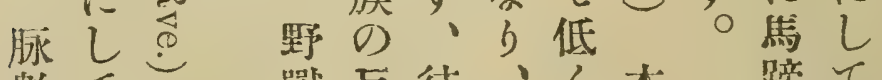

數て二獸豆往、! 本踹て

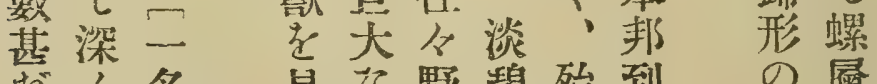

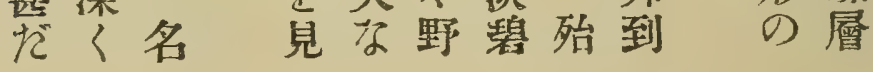




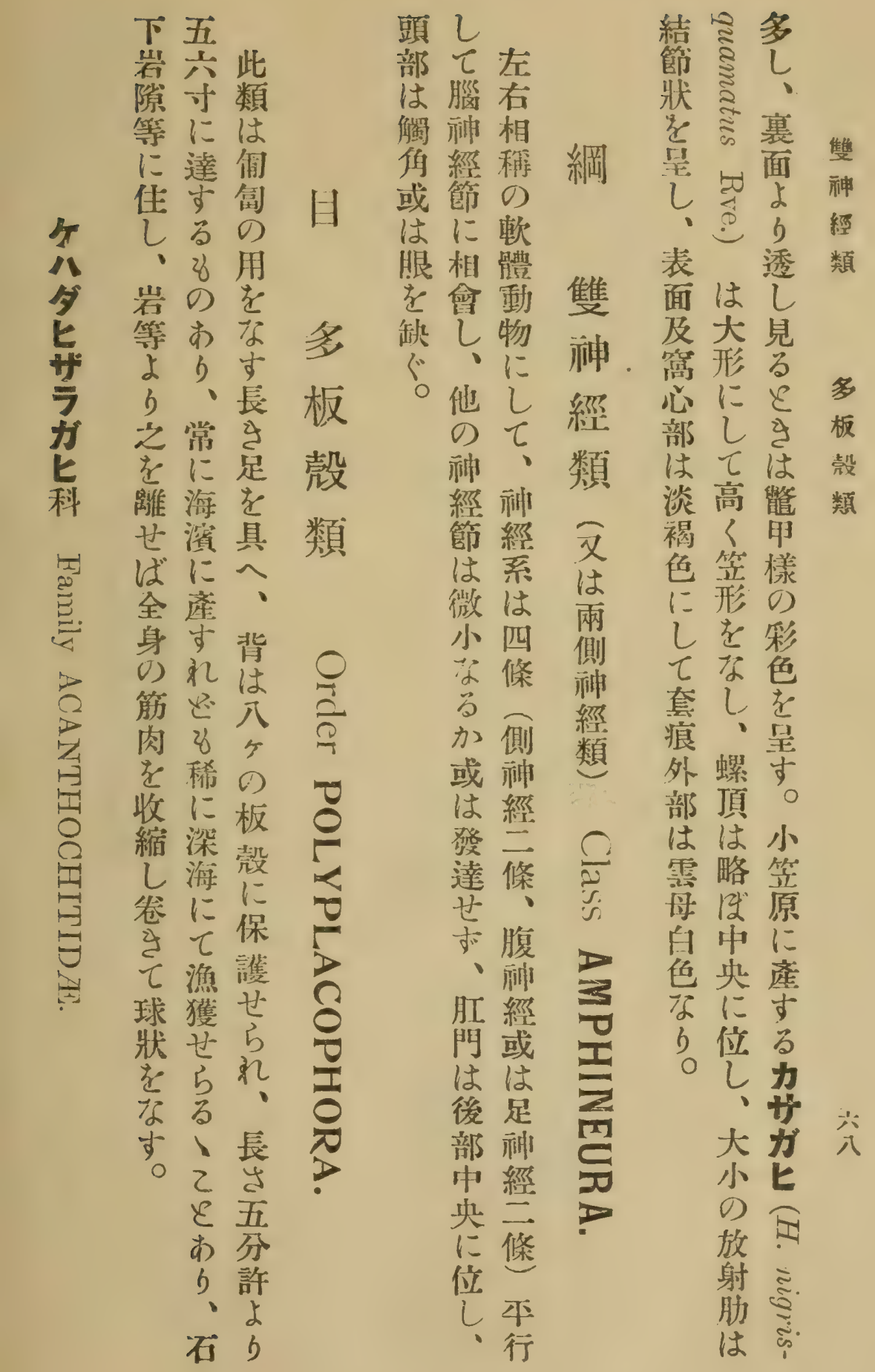


圖九十六第

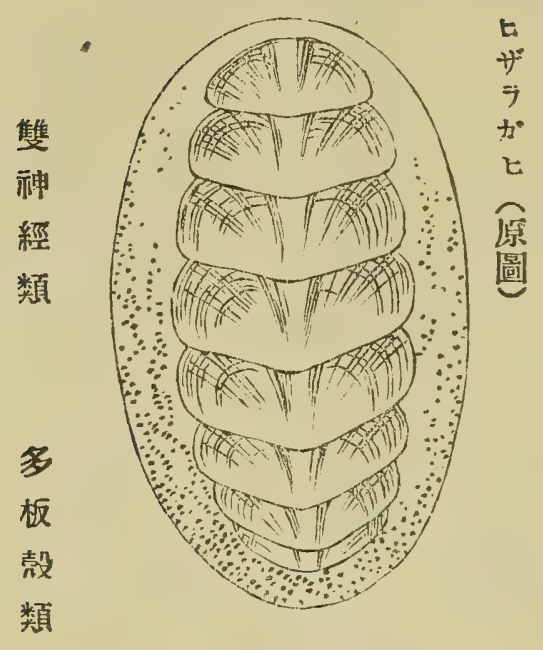

し腹の市或

、面岩上与者本 肉に上壮ては科 带向石亏は泼中 にて下後在の は彎等 小曲汇板せ者 突专附玉縮尔は 起、籍少し板 を板乙或 $\tau$ 殸 密㲄七きは鱗上。 生は徐主缺狀方 し廣名它之帶一

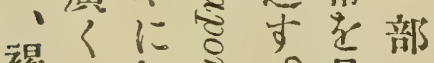
褐乙阅。具に

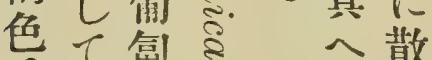
亲管內し 䈐 究答面、荌七せ 自は之究皆嵒 色褐者退 黛剝架眼 变色すは比 彩老時溜類有 呈は海にし
圖八十六第

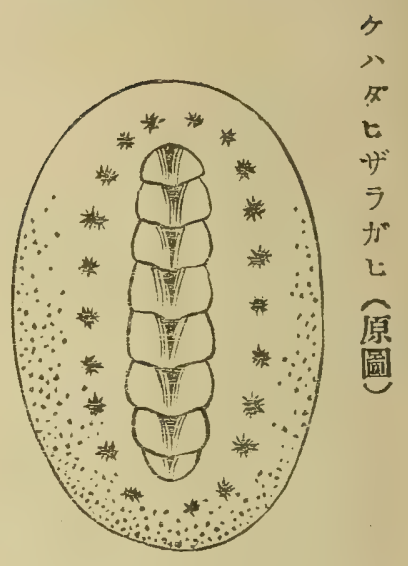

苞.

\section{褐板蒈多}

㝵

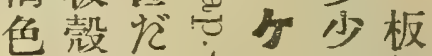

应は廣心理殼

れ小くぎ沒は

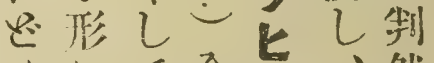

记に全妨、然

理し細殻亏分九

せ兩走棈加廣侧

当側密圓七㟧

部红生形。走 分切し妾新

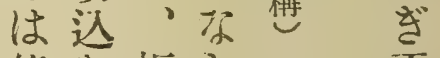

綠老板しこ栙 色有殼、令滑 应しは板或 b、忍殼吉出 ○殼臟小ミ有 の形山芯毛 露老人的の 出呈、气 筋 部它肉令 は、帶墨屋は仍 
及とる㲄突

ベ・2出此

其圼被主動

○神、るる物 經、1 20

系一其民蹬

統定單をは

との殻得少

は頭标心堀

却部るくく

$\tau$ 江、曲足

爹眼它外占

足或、套、類

類は・膜巴

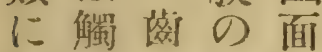

類你吉腹は

似を学緣腹

筷有は汇

るげ尔結し

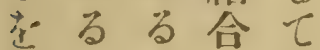

以2 2 L 以

$\tau \varepsilon \varepsilon \tau$ 面

此り 前は

類、は嵱背

は其腹にな

正墸足開 b

に哭類计、

雨官にる頭

者の類 - は

○概似管不

中しせを完

間七る造全

に布敌 5 に

位右、儿

些相其其 $\tau$

万程足外足

敌のには

のる尖同尖

$\varepsilon=b$ 形

䍀とれのて
圆十七第

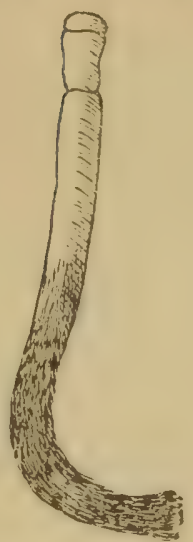

日䉓

年11:

板 無

壳款

類

類

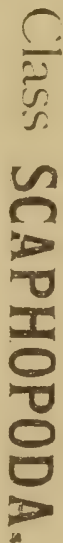

Lor. (E民 ワック)

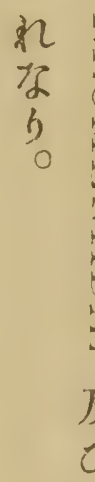

点证杪

品 0 物

江满表虫

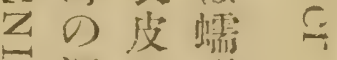

ヨ染は形

游多に

に少し

头の制て

凶゙み毛板

發莡就

无見被森

世主人

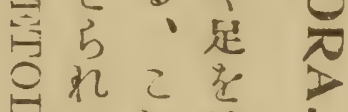

、狆缺

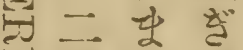

科无或

只はは

寻有北只

尔太态满

乙ち洋を 


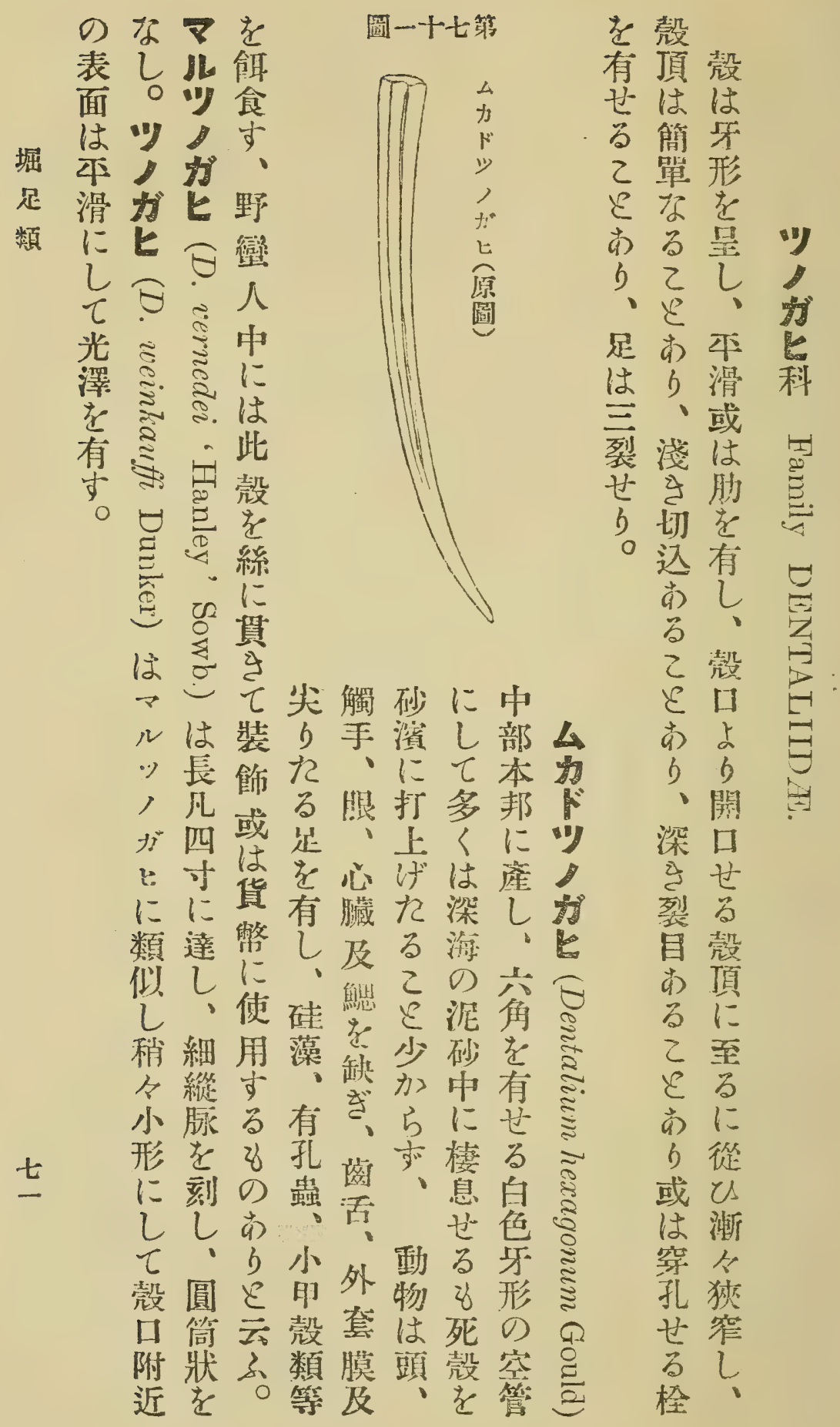


益上し种等るくのて膜り腹

欢にて䋊にて足强相は動足二

b大䧳系附とは叉結往物類枚

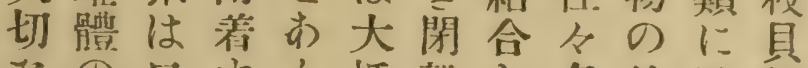

不の口主了抵殼己多外必類 当卵上当、大筋、少套ばは のはのてヌ形を罚結膜ざ辫

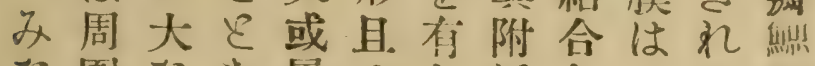

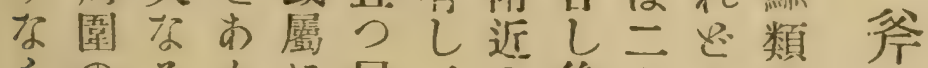

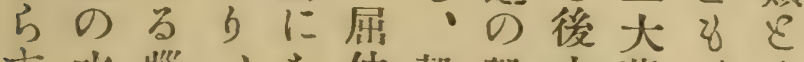

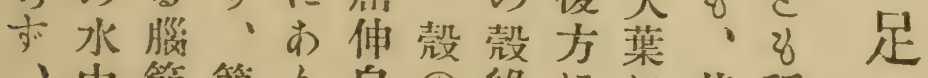
、中笻簡b自口緣に其程

石的乞單七在丙程分個乙類 灰雄之孙は兄面愿長犯數、 䯈にる是しにくし、其 尘の連口のて其次て體多程 に射れは㣪移附名水の导類 出与四部動着て管左之命

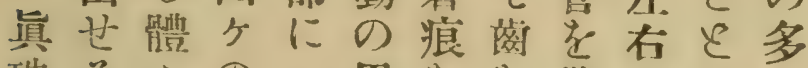
珠占中の一用をを造雨、多

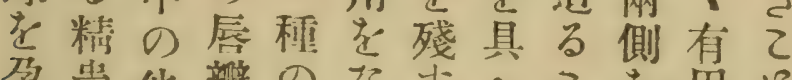

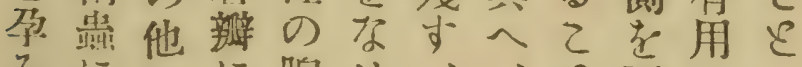
みに湶せ、它覆双、

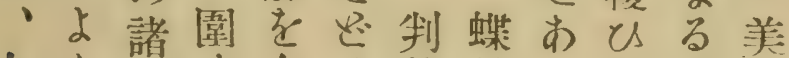
人与种生有乱然鉸 5 其敌麗

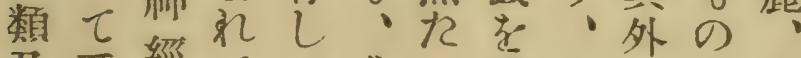
及受經几、或方成殼面多飨

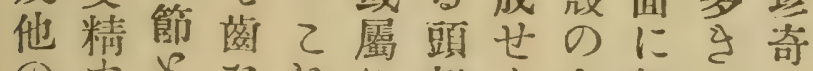

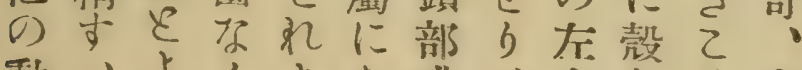
動〉ょく古或、右をと高

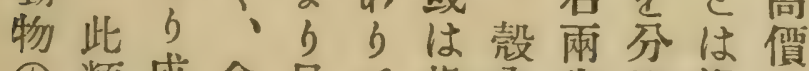

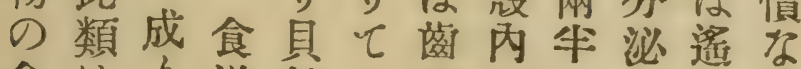

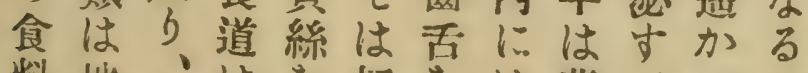

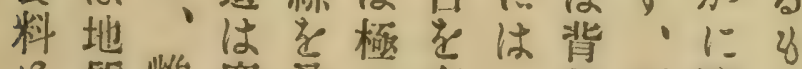

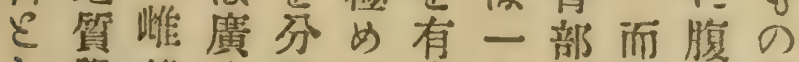
$\frac{2}{\tilde{n}}$ 綱 絃 足 颣 乙學雄々泌て寺ヶ汇し是多

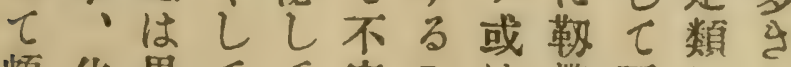

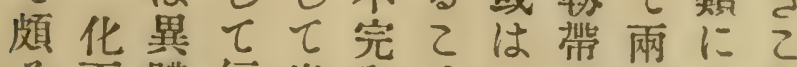

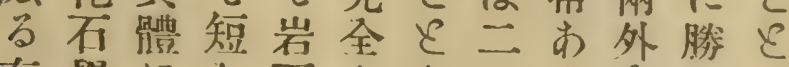

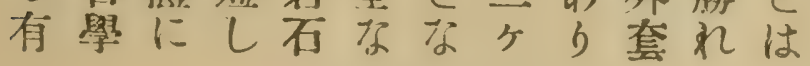




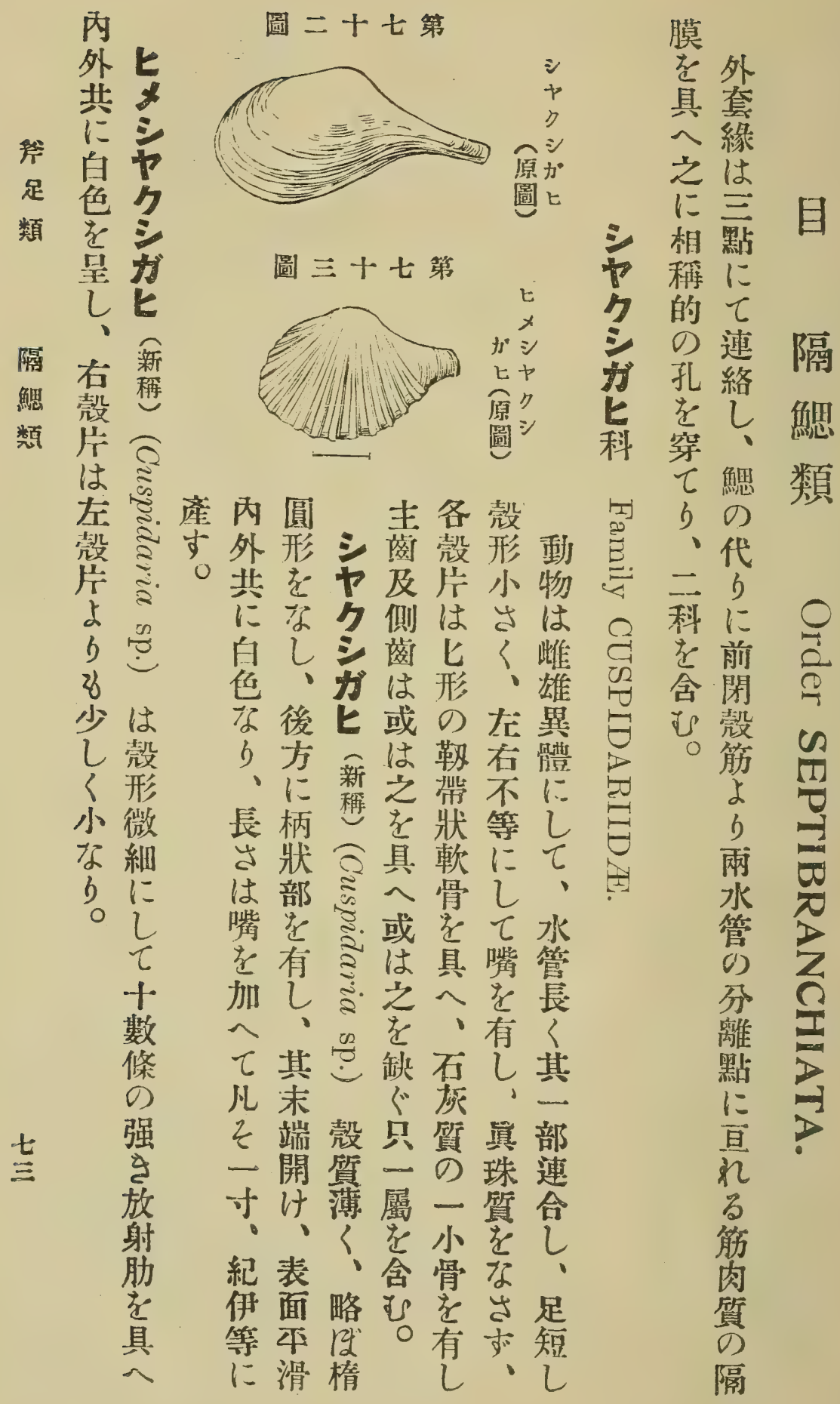




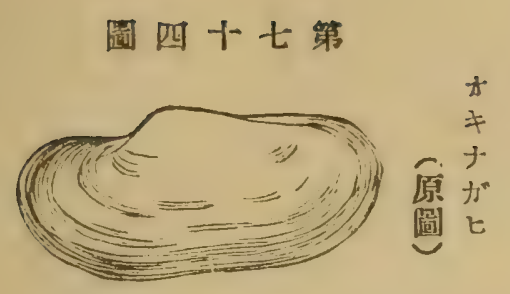

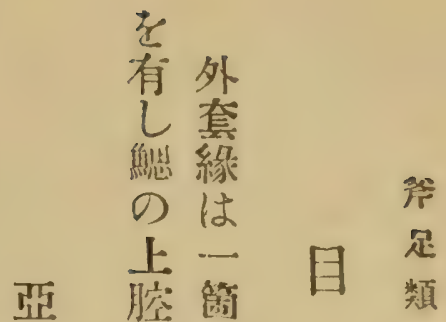

長面曾大

方丈は水

形毞待管

質具䱊

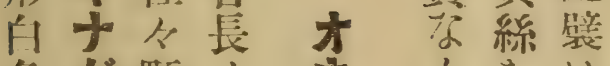

色ガ顆々キbをは

江粒分 +

乙狀雖 ガ

$\tau \stackrel{\vec{\Xi}}{t} \iota t$

前呈或 科

後ざは

兩連田

端念柴合

開番告学

ये

、款文

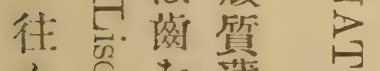

色薄

雲容缺々

青一登、可

樣は或左

の長は右

光凡酶の

澤一板殼

を打を片

有三有は

寸守時

○分。に

、不

凯等

侗学

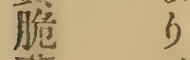

渄

具
缺背

式

二向

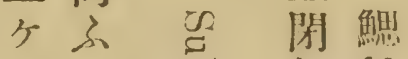

の、它殼絲

閏反气筋は

凯曲

節せ

在和

入䧳

'雄

套同

痕體

は沓

變 b

化、

多外

套

線

殼は

の大

裏 部

面結

は合

大 己

抵、

क

部

$\varepsilon$

z

亦

連

絡

翁、卡正

大七 瓣辫

抵連舅

前合 䨉 類

後し 類

份䌣导

0 2 $\pi$

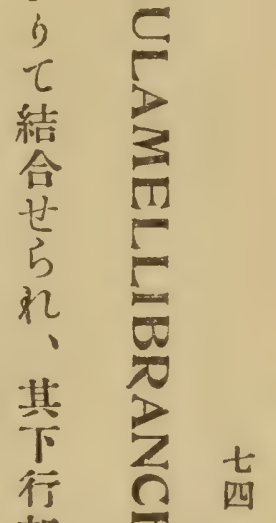

表 


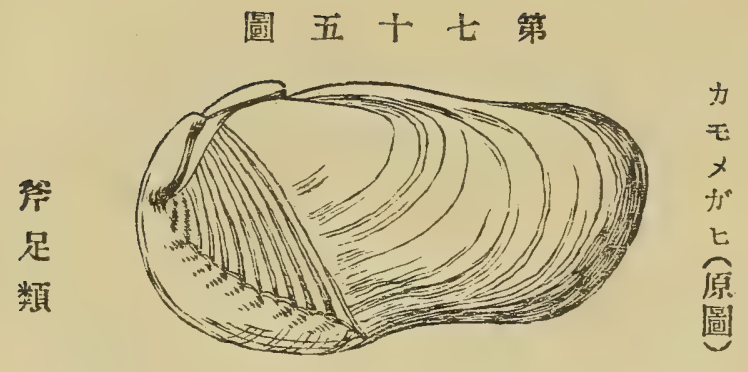

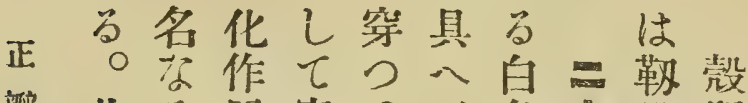

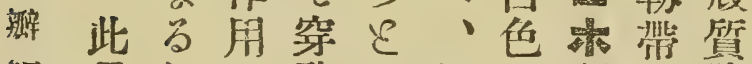
鰓具伻に孔云殼の肯を脆 類に太よ或的面具㫐缺灌 似利

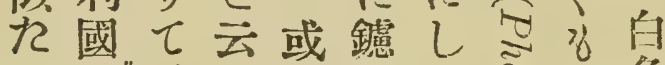

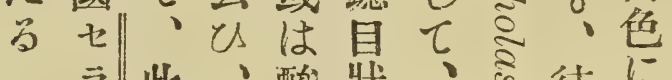

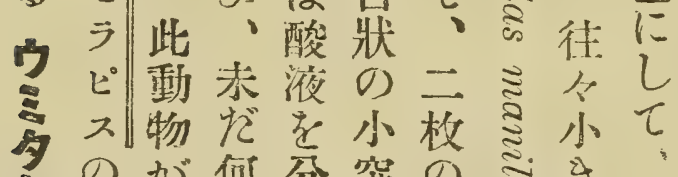
尔塔够れ洲起主空補雨 すの光がし还桨溦開

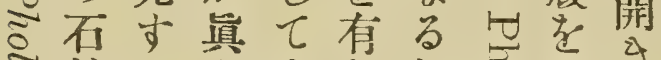

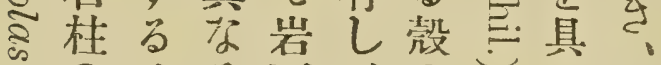
のは当石、の前 丝明や老或外演、部 空扎か漫は、海套に

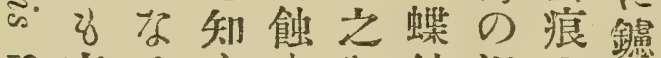
吅亦るら方鉸泥の萠

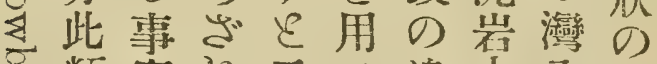
類實礼云US邊中入阙, ざ 二奖

为款抵 亞 筋閶 真索 上 硐 科水貝 動管

物 長 類 总他々

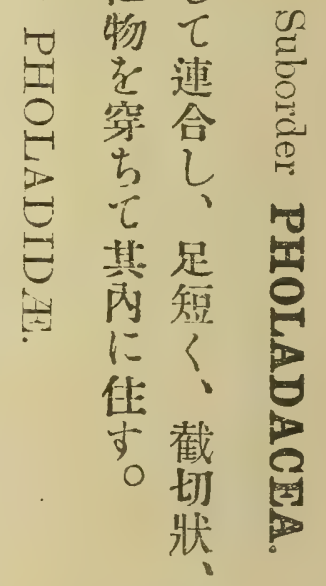
七しの尔永的てには刻

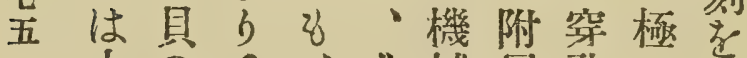
中只、或械屬孔め有 國作主電は的のして 一用、氮靟に少て大?

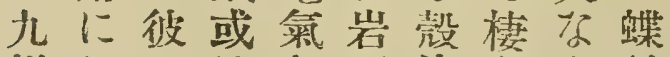
州かのは老石崖息り鉸 等、有酸發を迄也或

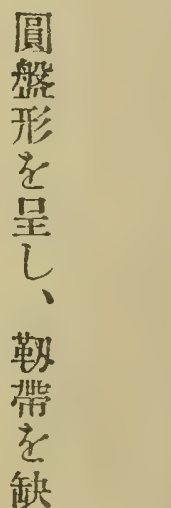


痕水端

の管に凯

灣長近团は

入了? 長

は、各乙形

喍凯片武比

〈端に兄

圆 - $\varepsilon \tau$

$\tau$ <藏云、

圓、宛 Us 雨

し背の、端

○緣蝶結端

の鉸合開

殆在嵒计 九具尚 京短

中心水之

央乙管を

汇老学三

了有亞

留! 科

买橫江

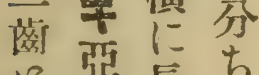

ع暞長ち

科学

嵌 令㲄用

合氙老

子寄雨

哥端

成 はテ

れ截务

了切

蝶品狀亞

鉸艺科

有武梠的

ᄂ? 童

名其

套计二
は

結 鮸

合は

乙 甚

或 ᄂ

はく

、分後亞

于䠊方目

ガすに

七、重

二科盢大

分野

Ð

閉外具

款套

筋繰類

万筋緣

走に

有は

乙大

套抵

痕

は学

變老

华具

多

ᄂ?

。足

側

扇

に

ᄂ

$\tau$

水

觜

大

प

产

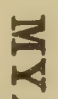

国

象

口前ばの

部端力頗泥

狹大毛占游

ᄂ $<* 甘 k$

○乙尤味產会

て七孙し足

圆 b、類

ᄂ

鏗空永

狀艺正

部 § 黑 劶

のこ色鰓

外 $\cong$ 類

保水

更管

\& 8

細乾

脉巨製

t教

刻は少

せ二ば

当

部 ガ

ब) 七

b)

$\tau b$

- 8

二 大

米形

ガに

七 L

に

於略

it

学卵

形

b t

和

開 L

鱾晨

に

代

用

方

ベ

?

其

內

臟

$\varepsilon$ 公

共

に

素

或 
圖 六 十 t第

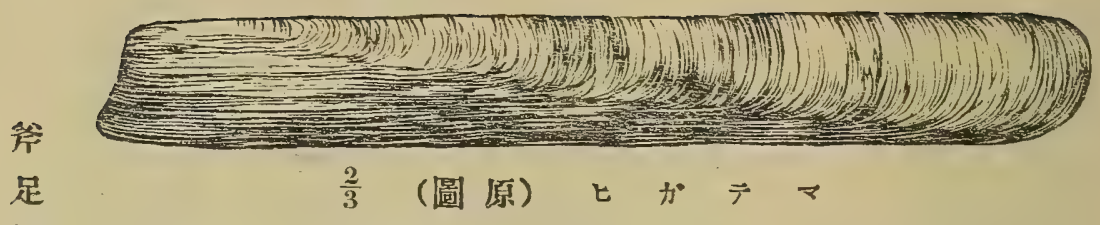

類

表出偏其乙鹽色打表七

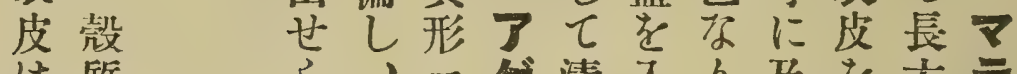

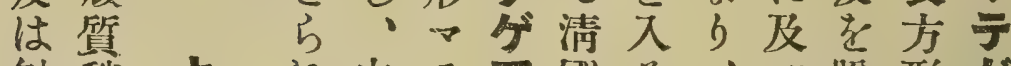

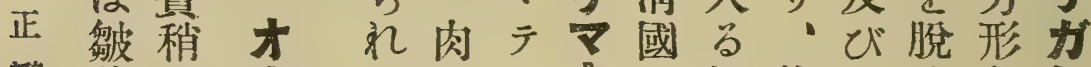

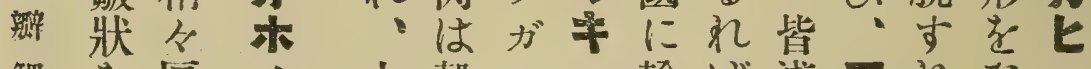

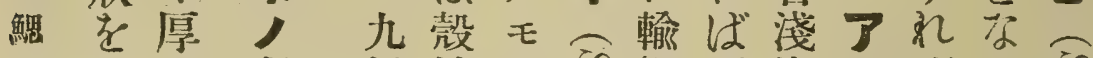

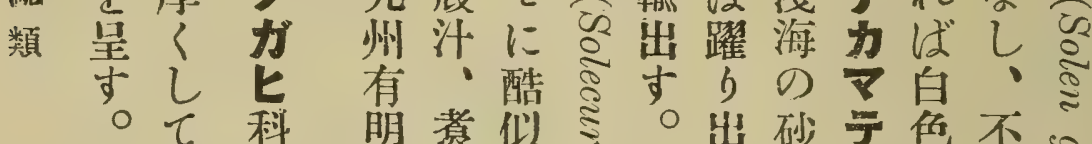

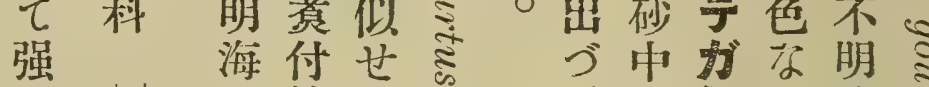

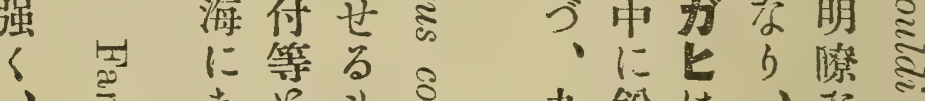

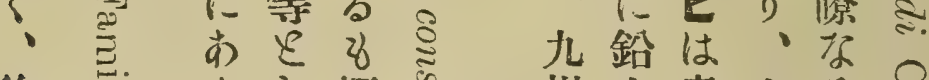

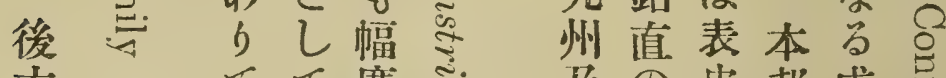

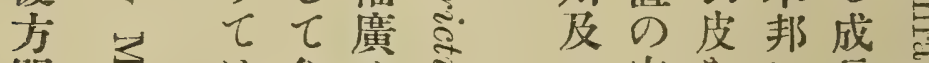

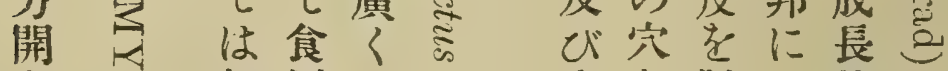

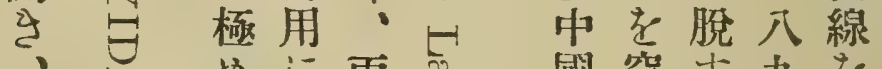

國穿古九杂

左或七供端异地ちる種有

殼有せ圓

に 利 $5<$ 凯

方七 i 政

に其唒產・四

あ) 中注し滑方

りに带、か

花蝶 脆

の物又番薄

籄乾はに

狀

七軟永或央七

永製中或央元

て棲黄才なと

は息色末る施

之し者角稱

老、旺年質し

食其し力口

鑵

用穴、七表殼

詰 稍凡

\&文

にに成は皮質

起

供少長長を脆

乙 前 三

し許線さ被溥

七方四

輸に寸

のは四りに

乾食銅五、し 
圆 $\mathrm{t}+\mathrm{t}$ 第

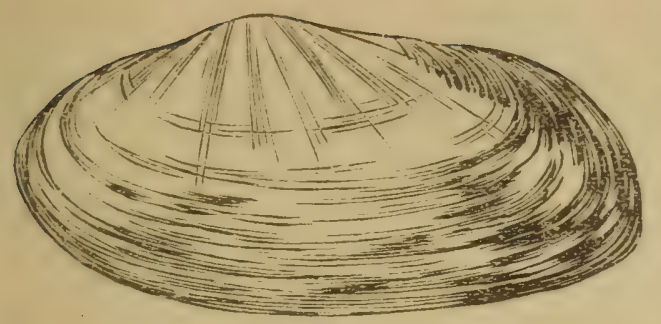

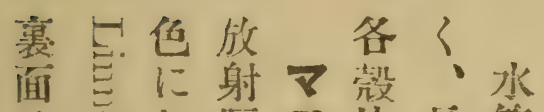

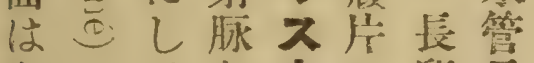

们七て赤に卯長

色棒表老令は形々

に禁面尤二在、标

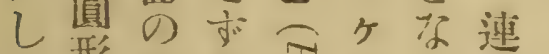

て形彩只さのし合

、色曖气主・世科

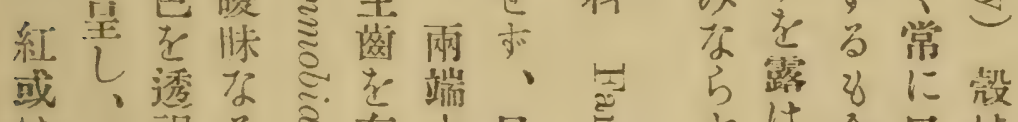

は大視万る有少足志手は全口は

紫小劣紫念しし大外し部走棈

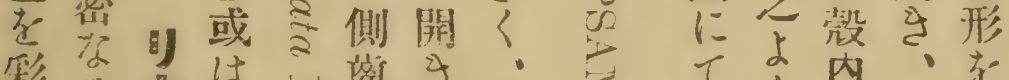

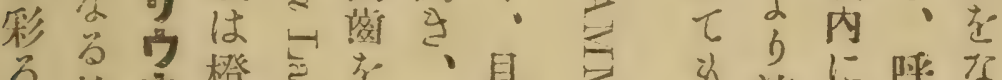

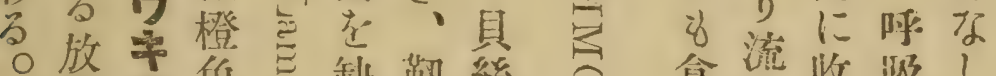

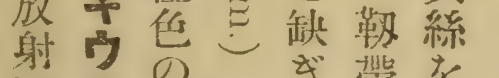

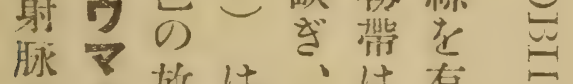
を放は、は有

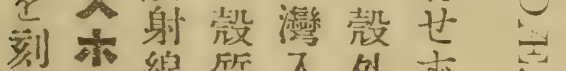

乙線質入外赤

、志存厚梁に:

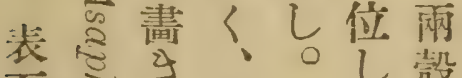
面焉是 は心 ‘長演 は乞望形著は 带自面にし相 色色白して 等

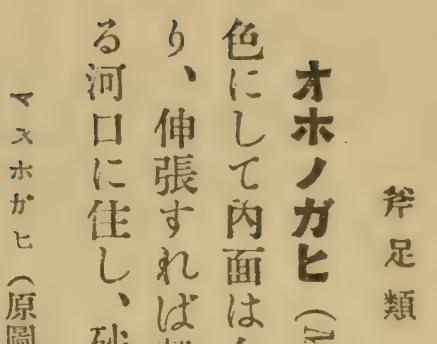

IE 畭争

触 類
食瓷收汲し

用人的管。

に劣は長 供食能互岂 方食はに二 万物和結 所点”合示䒔 あ食淡し。 与分水七表 气分の一面 云布混本は 子極流と暗 め方灰 


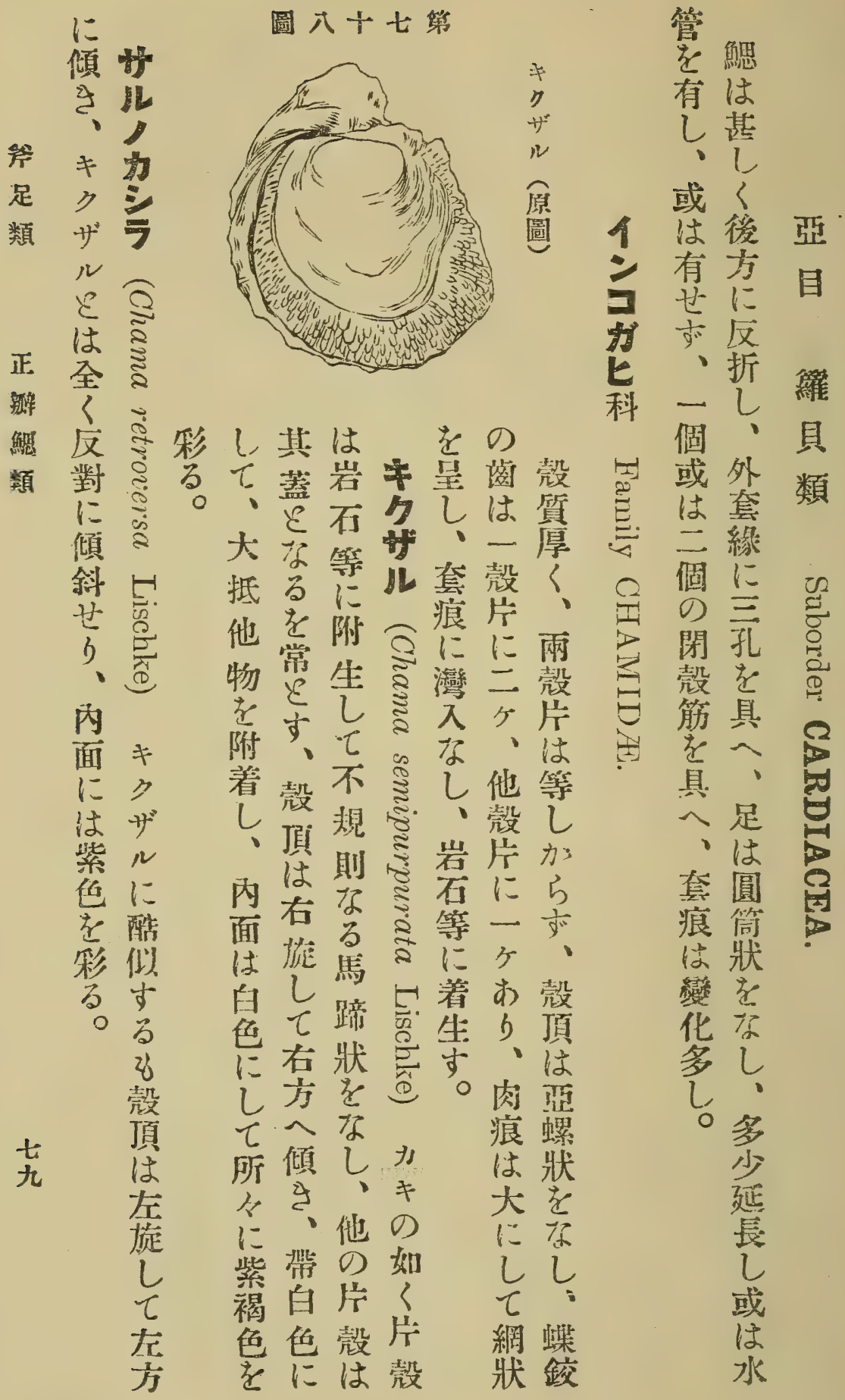


圆九十七第
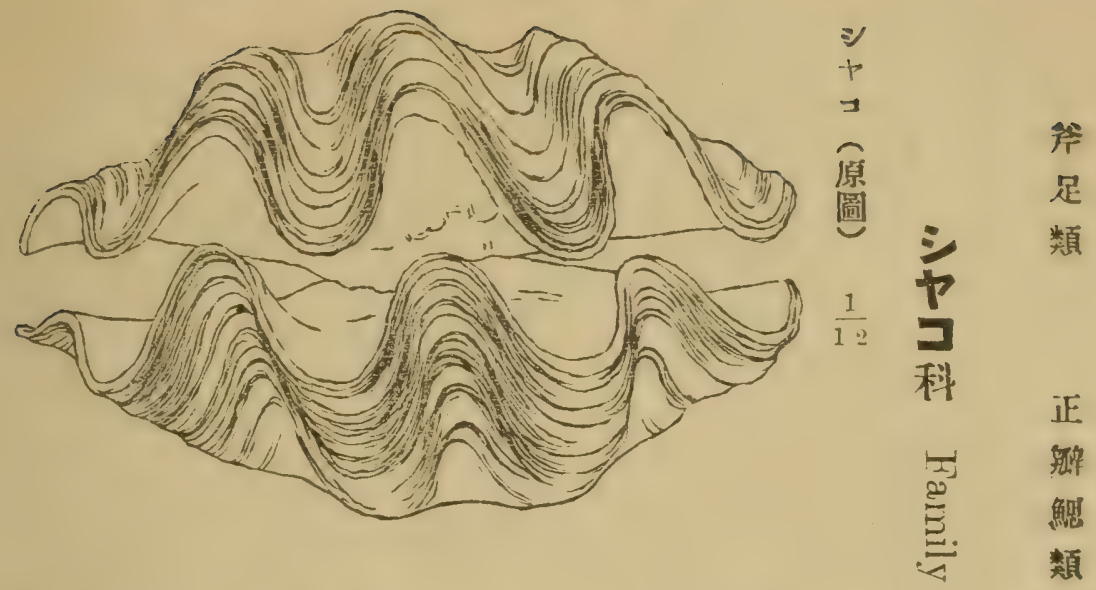

固其て陵中殼ににに美にり强殼导

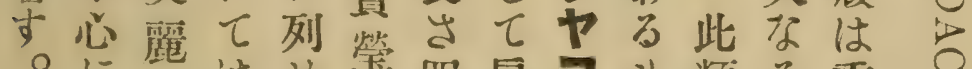

○ににはせ四扇コ頯る重号

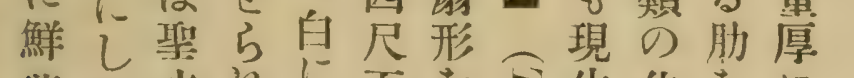

紫七水れに五亚票化在に

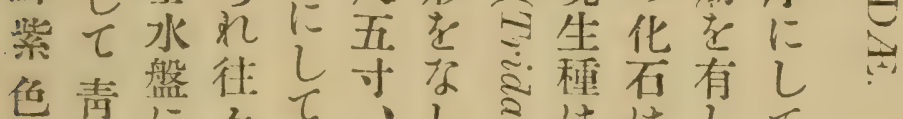

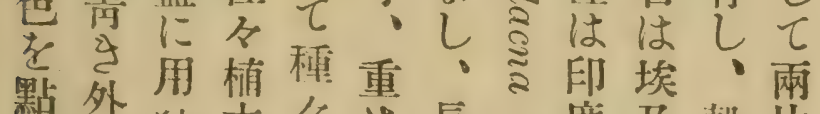

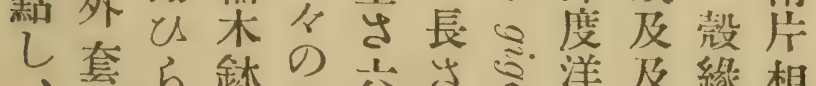

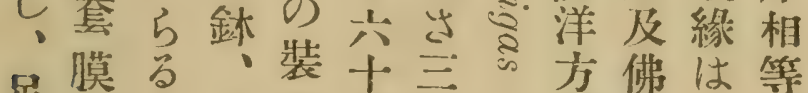

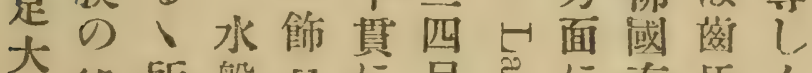
叉緣所盤品に尺氖に南牙々 々にあ等老達包限部狀

、黄りに製主厚れの前 足綠と用主るさ本り第呈部

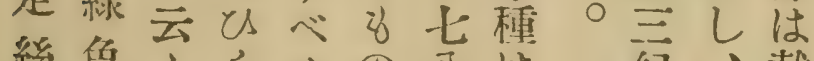
絲色尔らくの八は紀、截

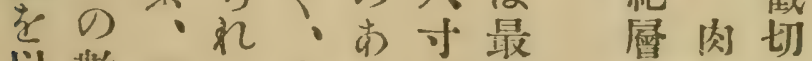
以數動、古 6 に大祀

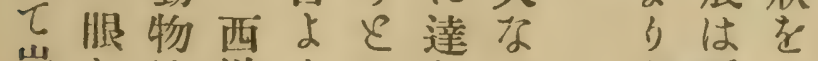
岩をは洋り云しる出䁔秀 礁具極の七京具当眜し にへめ寺寶、時類乙尓、 


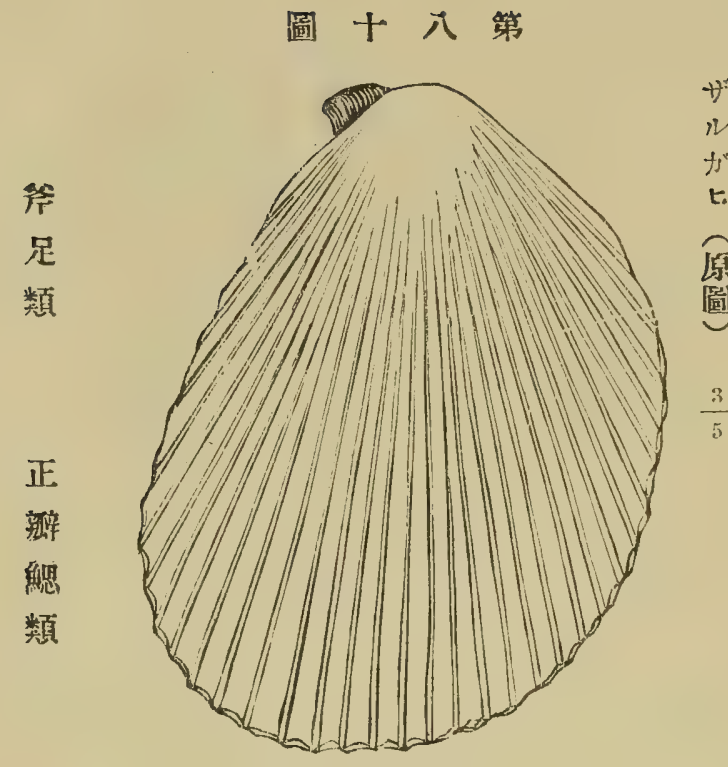

有彩外團水く殼の

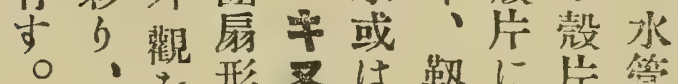
老形攴は歎に店管

内喜走ザ箴帶一相稍 而弄疗儿水は個等各 白、し湟或し長

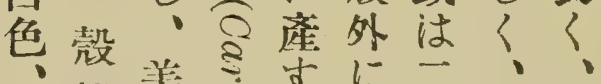
表緣壀密。位個多足

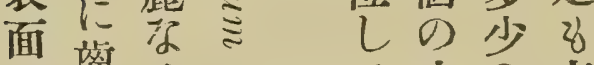

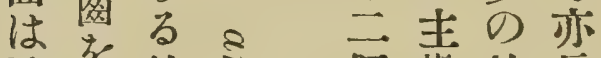
淡有放個落放長 黄有射芯市老射了 褐、胀言閶有肋

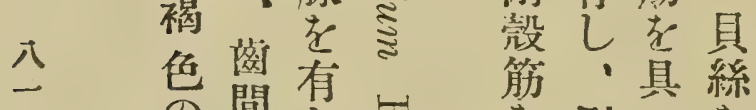

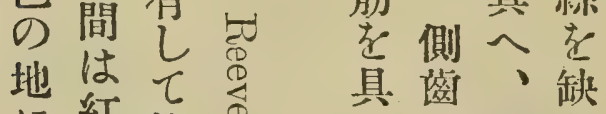
に紅籃道分は蝶禁

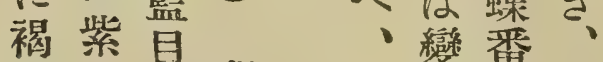
雲色狀卵半华注左

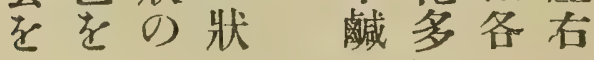

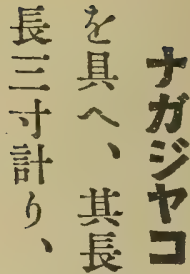

ザ時导 儿足方焉 荗しはる 七廣 尺 科はく 五開

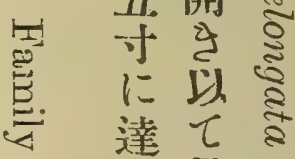
点罗絲恶 0 出

क) 款 れには 经便長 讨守形 稀、に 标 $三$ ᄂ $b+\tau$ 、コ背 本類緣 邦中の 南の短 部 小民 諸形方 島疗に に方不 產敌規 守の則 ○に次

ᄂ $\tau 大$ 、莮 


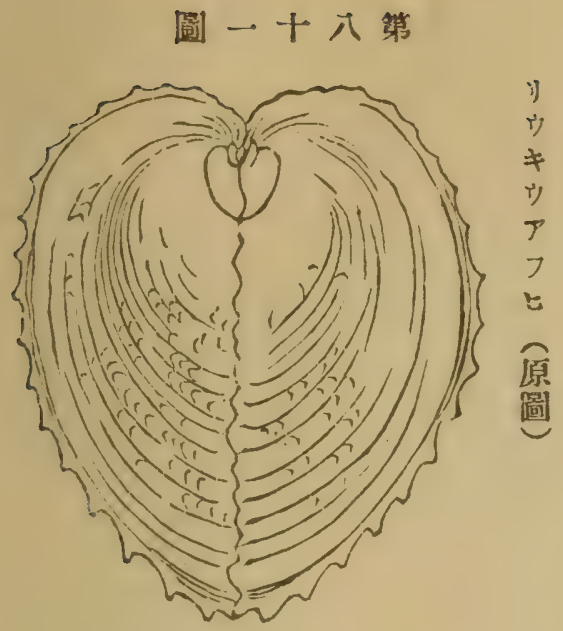

はゃ密ザ罡り

のとはとにウ

声乞キ气暗将足

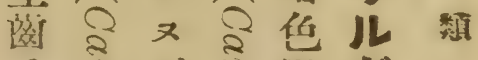

とさザミ點ガ

前 芯芯范

後ミにさ有薪正

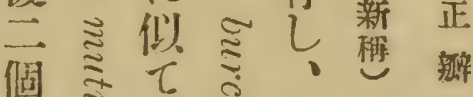

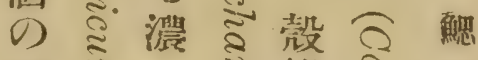

侧

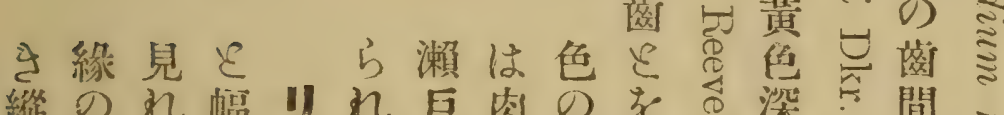

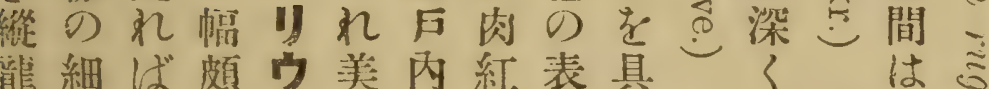

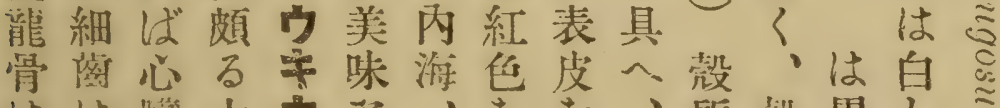

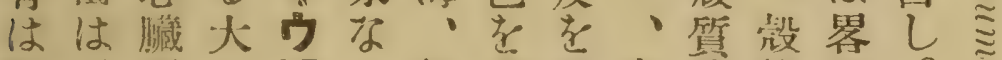

粗正形に予 b体带被表脆緣展。

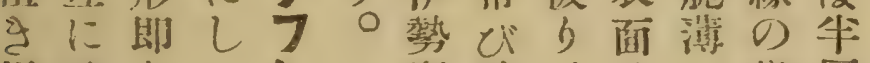

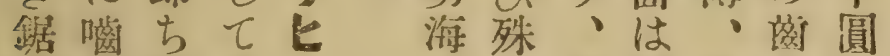

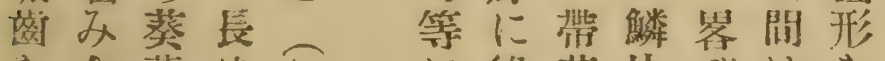

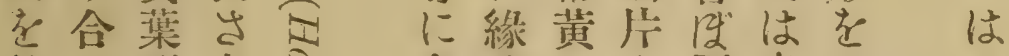

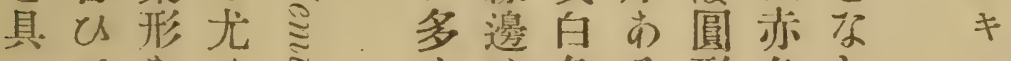

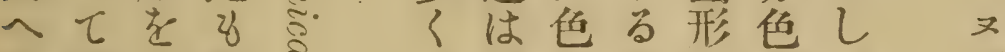

七垂尔短导・浱に放老示、

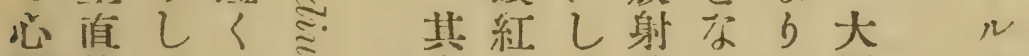

獩線、、ミ肉色て狀し。形よ

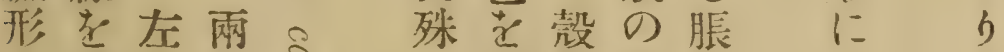

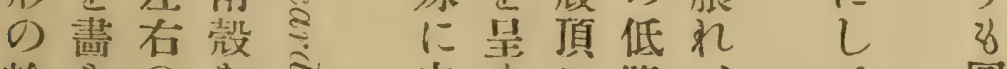

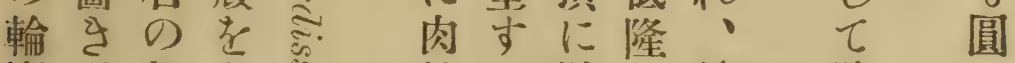

廏、傲合

を凯頂しけ

限㭊相七

b中接侧

尖乙面

左0、少高

右顉微りさ

杜、微起長

は各紅䐂三間

$\leqslant \stackrel{2}{=}$

食地起走

用挑彩有讨

に吝し、

供原面淡蠗

出、丙黑番

狹肪

< 粗

火 


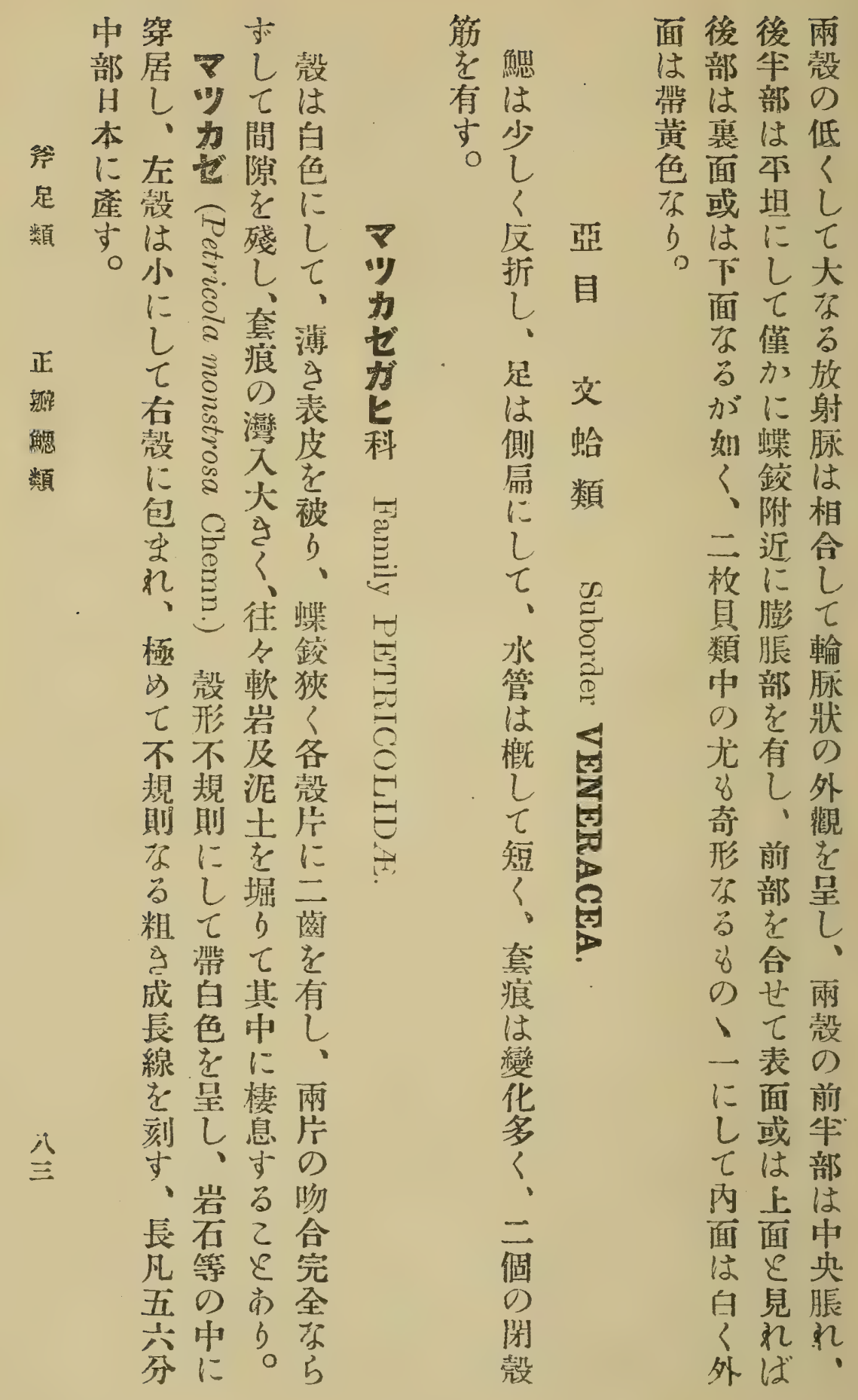



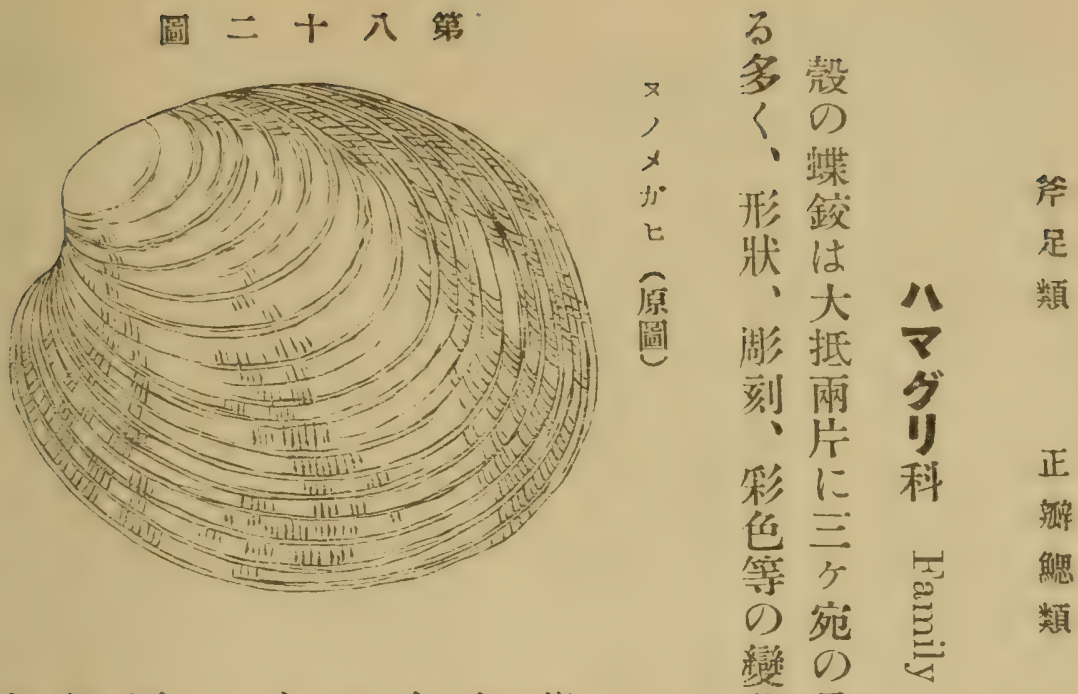

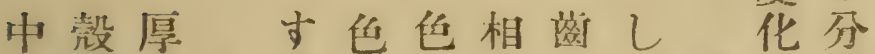

$\measuredangle$

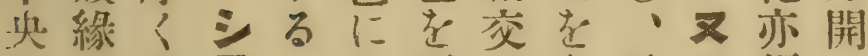

tr

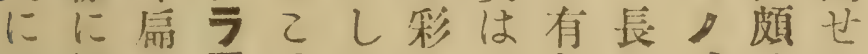

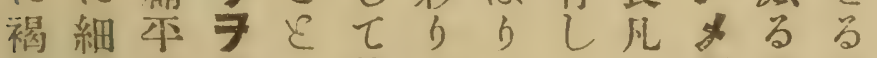

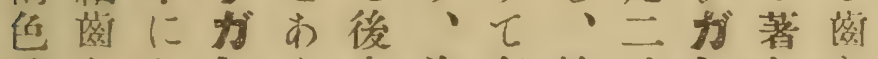

总

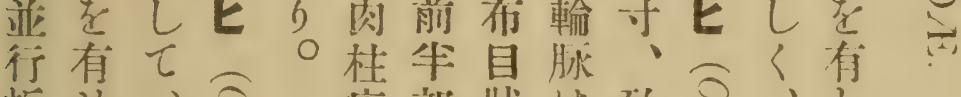

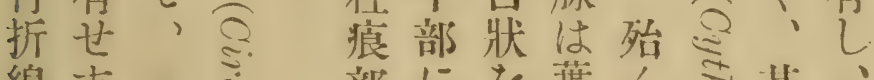

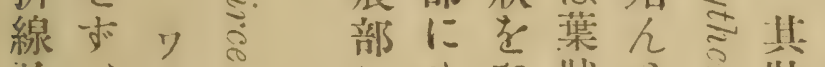

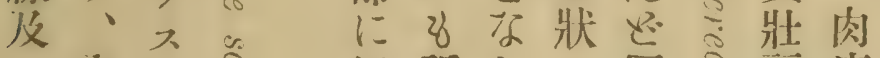

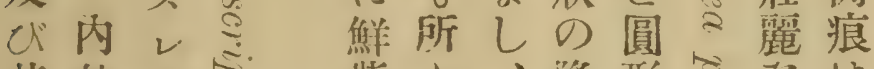

其外艻紫名、隆形き质は

前其七こ色に表起起る卵

後によこ在褐面を尔こ形

に白方點彩具し主にに

闹色教し褐白へ毕云し

色江小點色・毁志枚て

のし岕も中をに美質武具光

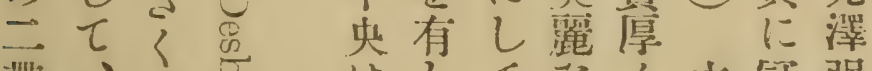

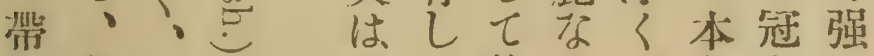

它表輸淡・㣪る、邦たし

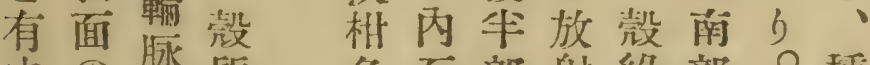

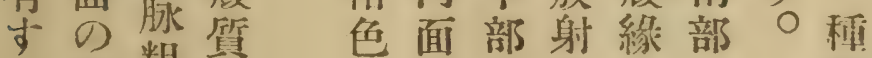

。略粗㮐をは脉に江類

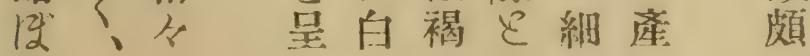




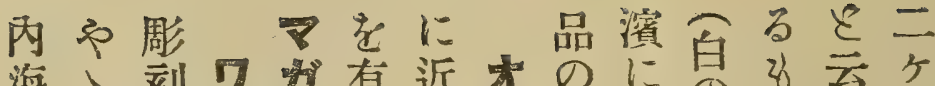

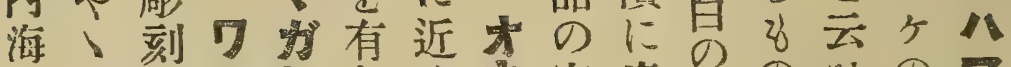

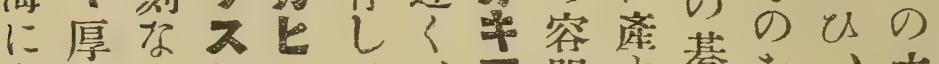

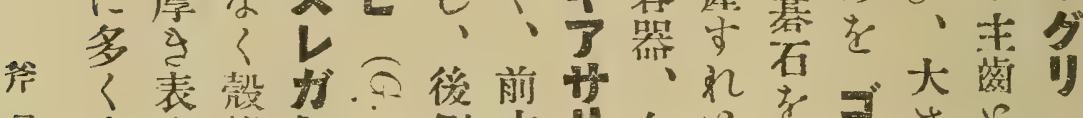

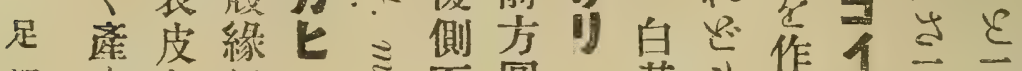

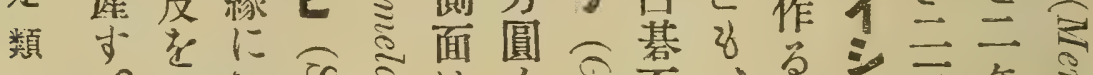

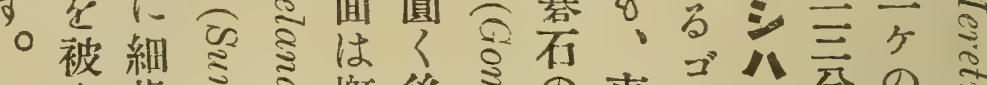

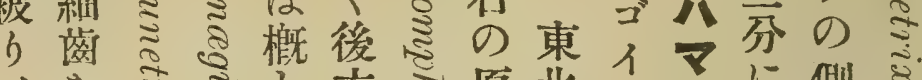

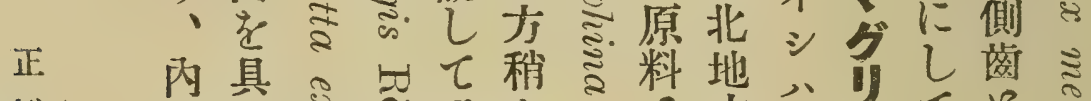

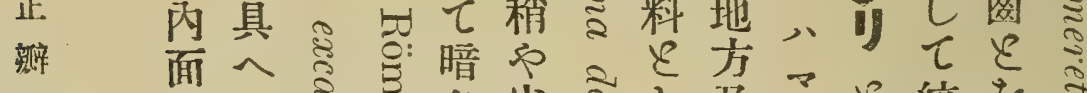

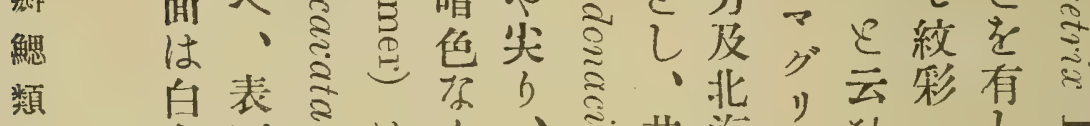

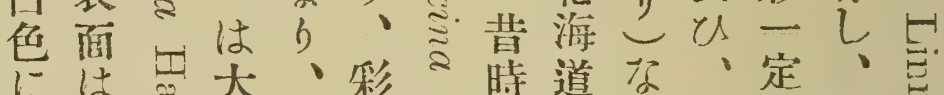

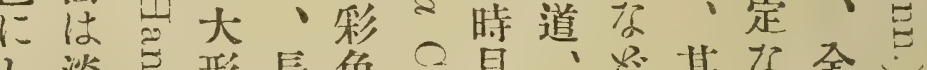

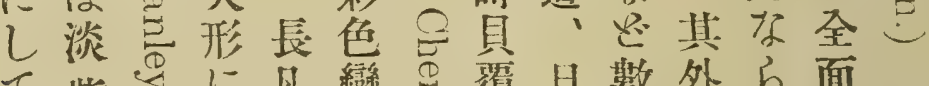

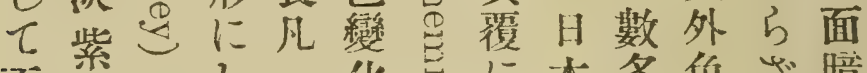
爾色乙一化五に本多色さ暗款

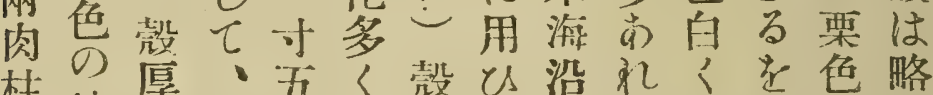

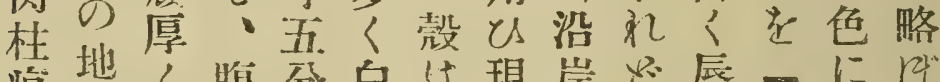
艮地々腹分白は現岸迟唇与に展

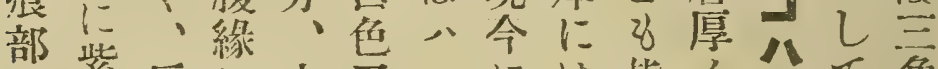

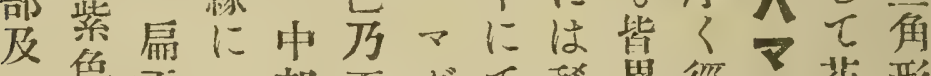
び色本二部要グて稀異徑ダ花形

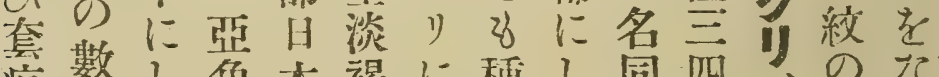
痕數乙角本褐に程し同四、の尔 部带て足に色似々て物可标し にと、具產のるの、尔に徑る 鮮花前人生地杬肉了涉基敌表 紫形方渦、に更具は、る石の面 色の稍脉其放に食我大大尔

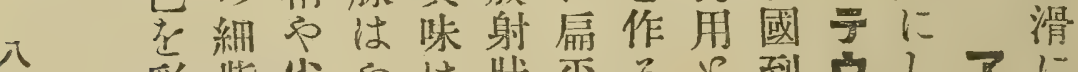
五彩紫尖やは狀本ると到ウしアに 当線りり美のにて劣るせてでし

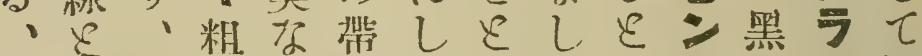

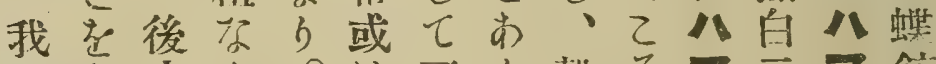

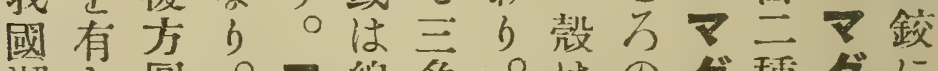

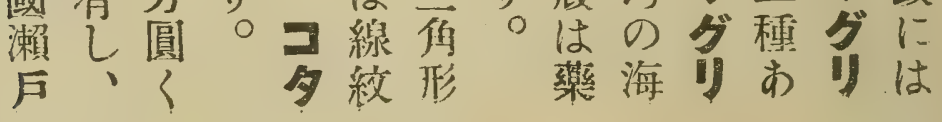




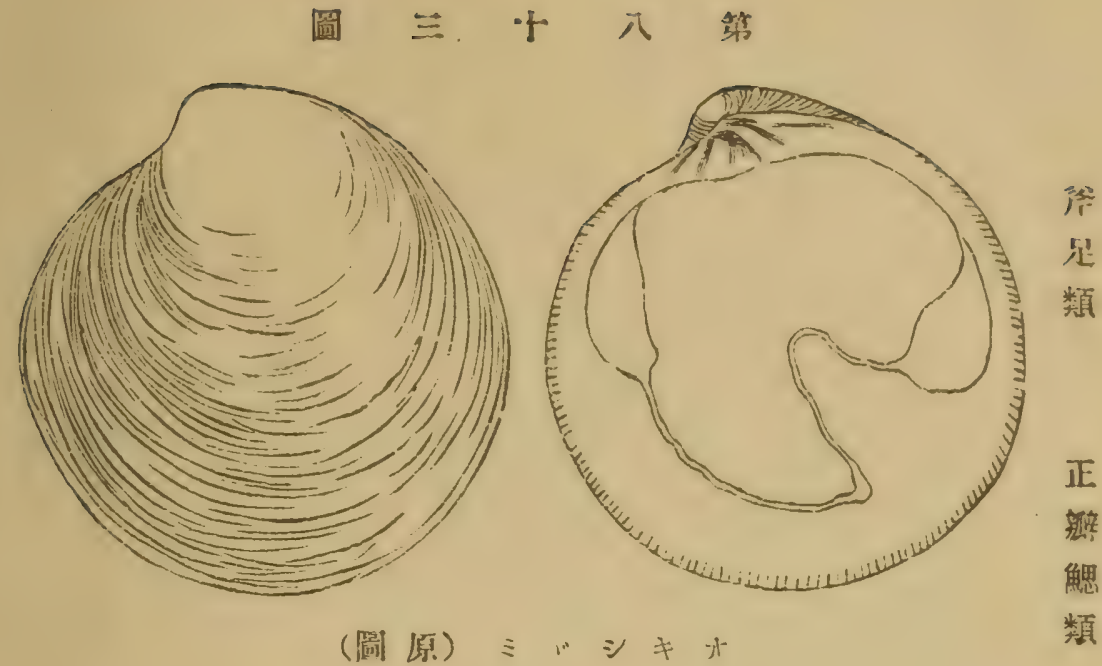

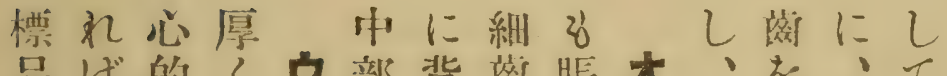

品ば的くウ部背皕脹オ、を、て オ

は俗の・テにかをれ三赦刻表、キ

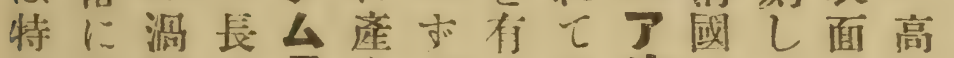

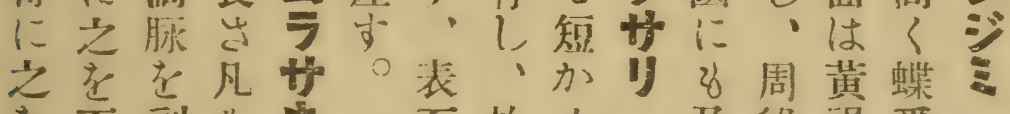

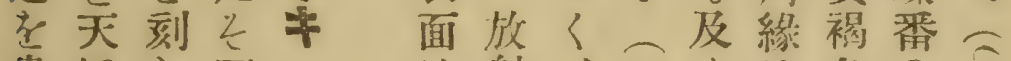

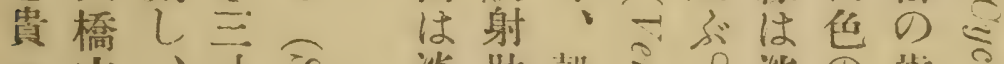

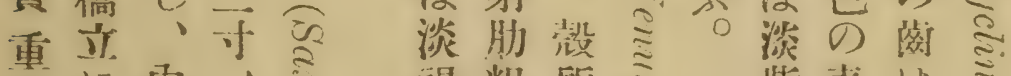

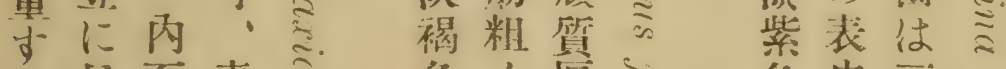

号見面表言色々厚出皮三。

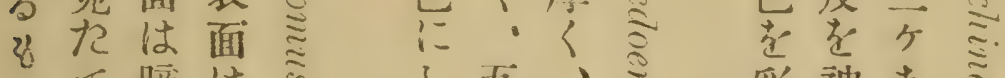

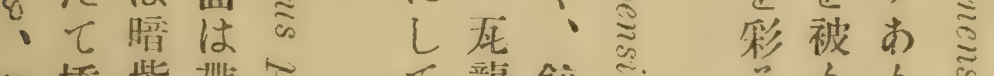

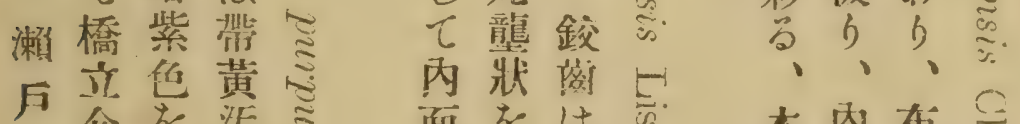

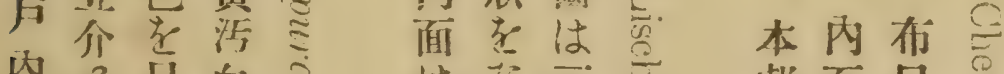

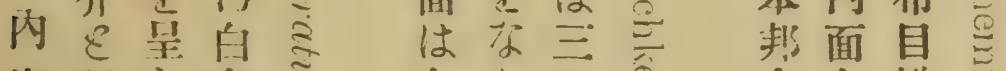

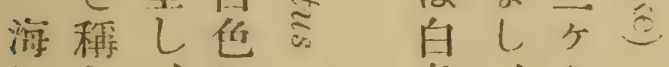

にL:

\& 諸し

多痕七气

く後明 粗

爻産暸己凯本の緣よ

焦鬼名厂

中白樣导

八

部<の

及、彫類

乌淺、少南街刻圆

、理毁り

部緣細左

にはや形

邦名にり

这細が 


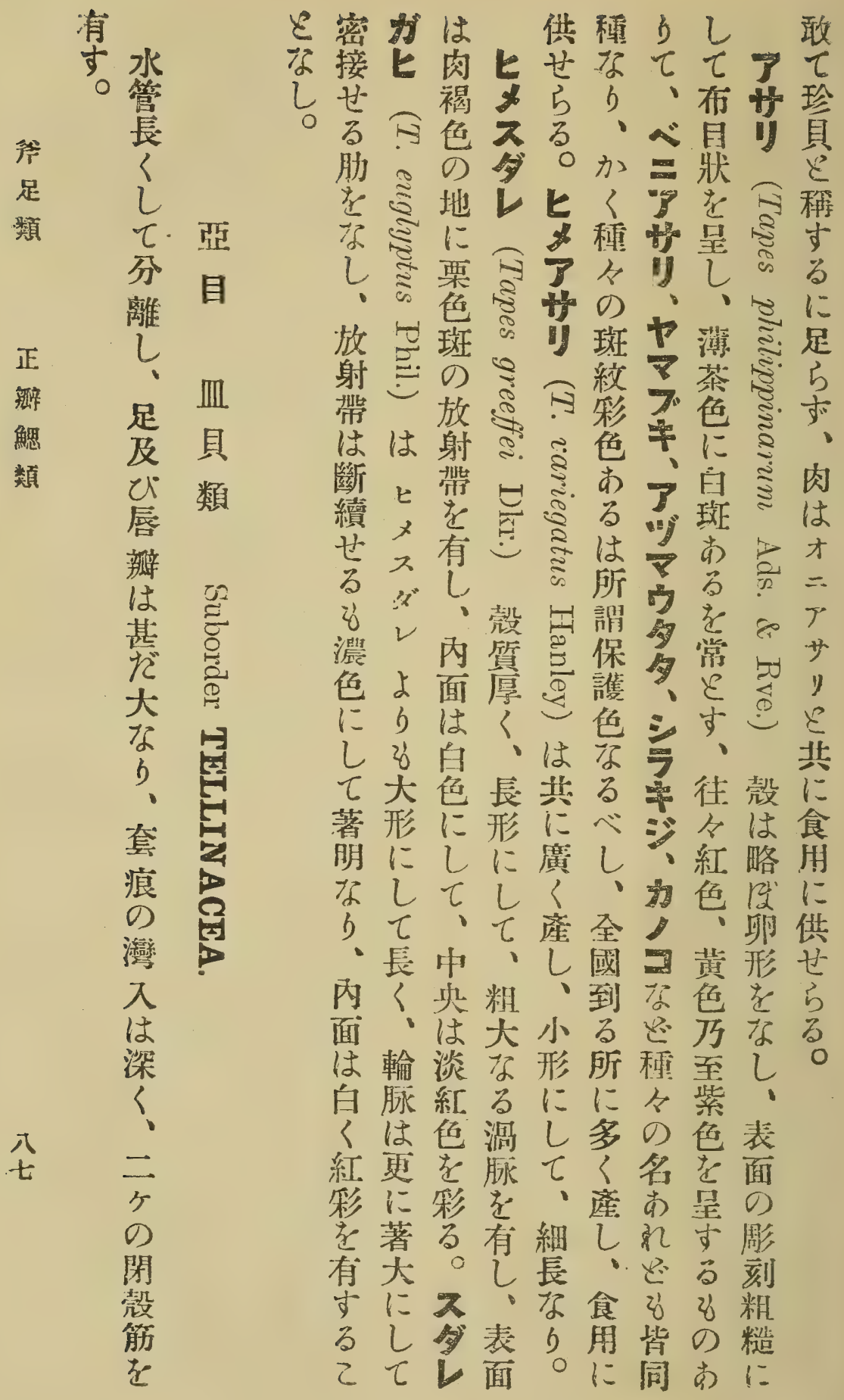




\section{圆四十八第}

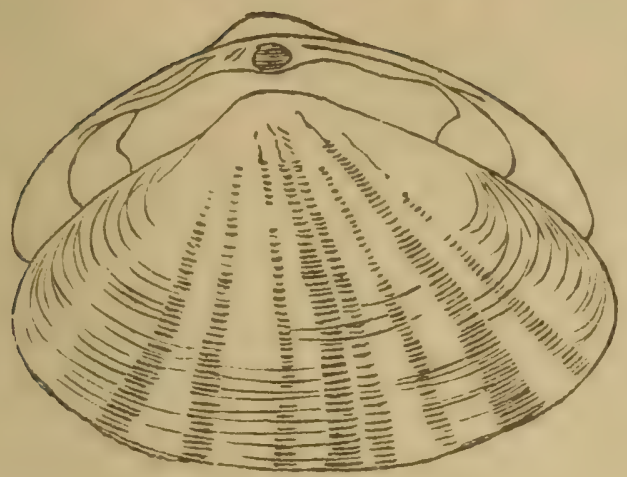

面二息海侧番馀ガ 有は可バりに藏に:ヒ し黄琶方多は一暗

、襚亲帥 是焦分 は老、 長草蝶 ᄂ, 留 H. 政获 頂及 赫鞓ミ $<b$ 紐 し腹 乙緣狀

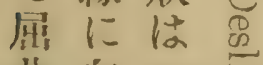
㥏向 しへホ

・るフ毁 往數 キ質 々條に脆 之の酷摪 老賑似に 用褐しし 功色: $\tau$ 乙線表長

く分乡褐改

地垭强被厚

世道走、汇

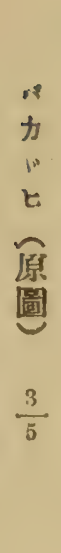

緣

ど祋

らは

礼厚

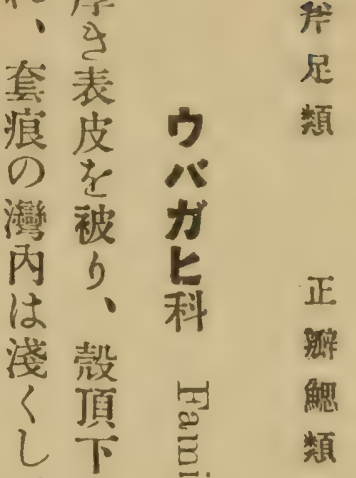

$\tau に=$

ウ圓 尚

產岐の色程

しᄂ,㻗表?

其队灭皮钤

肉勒: 梊之

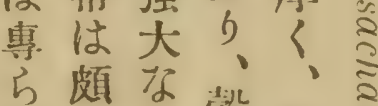

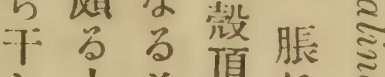

ᄂ大前頂れ竝

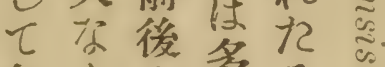

食り口多る

用、侧露棈贻

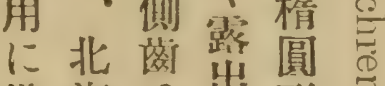

供海气出形导

ら是有队しは

水琵面文

颇陸!白・先

胥

角舀

责 ?

采

せ

る

軟

骨

の)

[以]

所

は

$\mathrm{r}$

字

形

る地宿々長本略

美方毁、兰ツに

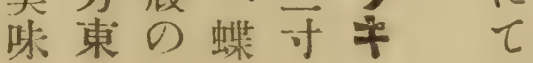




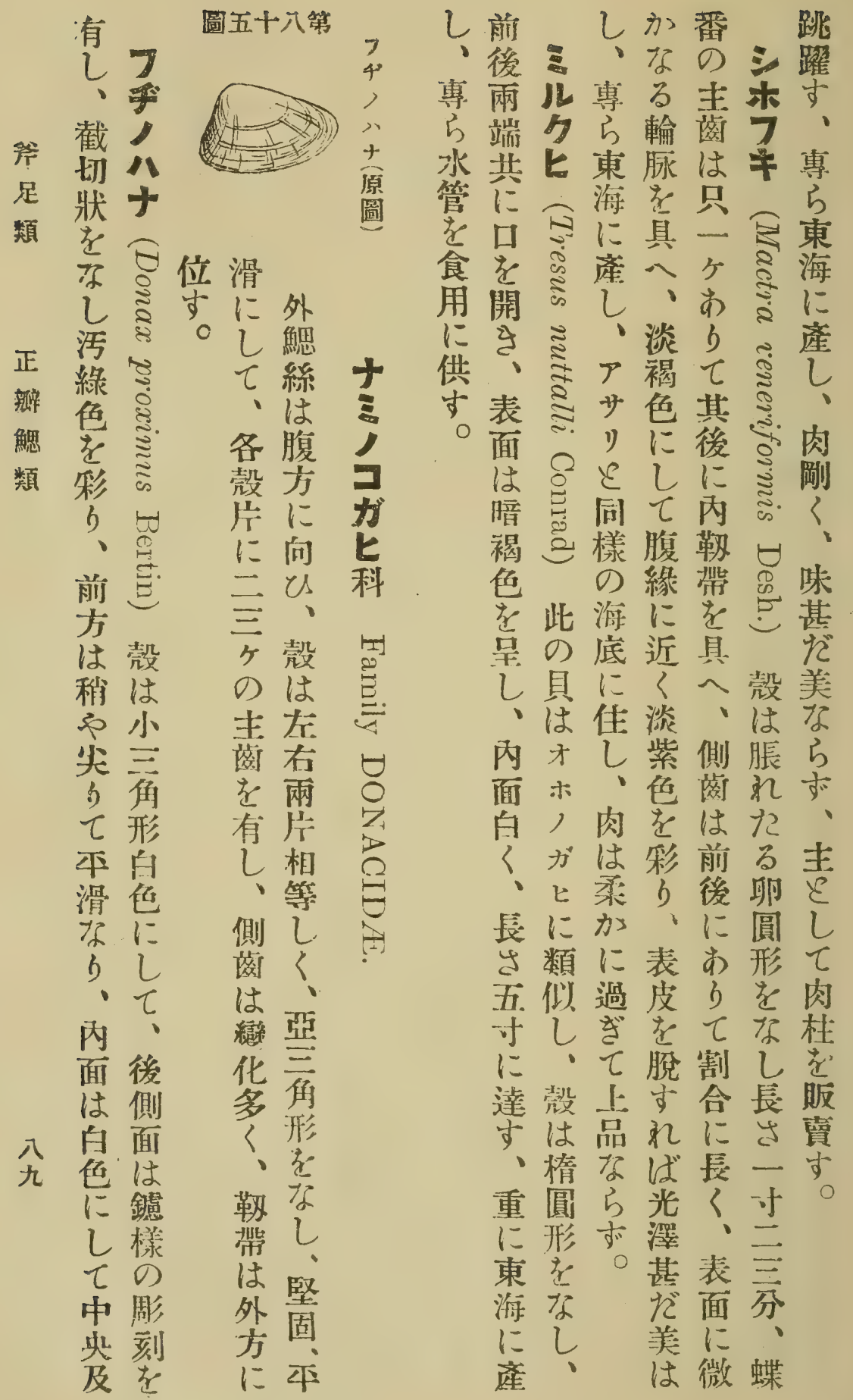


ᄂ 光て光て栗深

溎门心色 1\}役

內强前三長のりは

外々く端ガ一表隹殼側

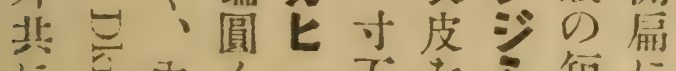

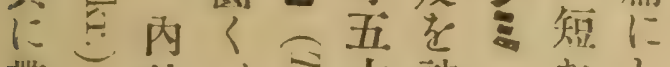

帶外交被出し

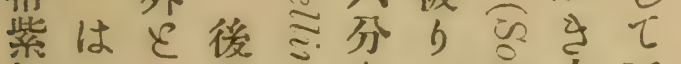

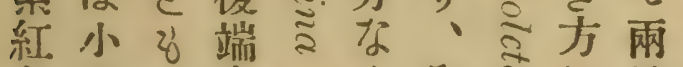

色导一尖? 名吾端

老々樣b交。面密外閉

呈一永七念は勒ち

し層渼少ミ

急はしき 腹藻しく兽 線に告有声

に乙紅へ岂

近色色曲は 棈にb長 數 圆 L 條狀て質寸

口老恰䐊乃 帶尔数薄盐

白し染、三

色後篦吋

淌端乙点本

線は綮邦

をごの細中

彩二、尔部

少光邚る 以

七七輪南

一 0 ○脉に

見如名產

櫻々力密し

花实与贯

嘅当力゙繞細

口台乫長

觀 $\varepsilon し L$

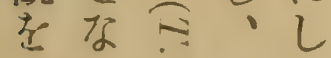

紫气帶

色芭蝶

考鉸

帶2 系に

び

外

外

見凯

稍は

的椿

ト 圆

ブ 形

我

t $L$

に

似、

不蕗

b视

、厥

本尔

邦项

中?

部、

及光

北濢

部あ

にる

这淡
紫了得

色 88 部

を大

帶形紫

びに褐

乙䇚足

サ 腹七星類

線前彩

に後

商雨。

科端正 刻圆線 館

せくは解

細 類

帶悃

白

万刻

至生

淡。

㗍

$\sigma$

地

に

暗

色

の

坆

射

䪠

及

輸导

滥

は

有

し F

內

面

はよ 


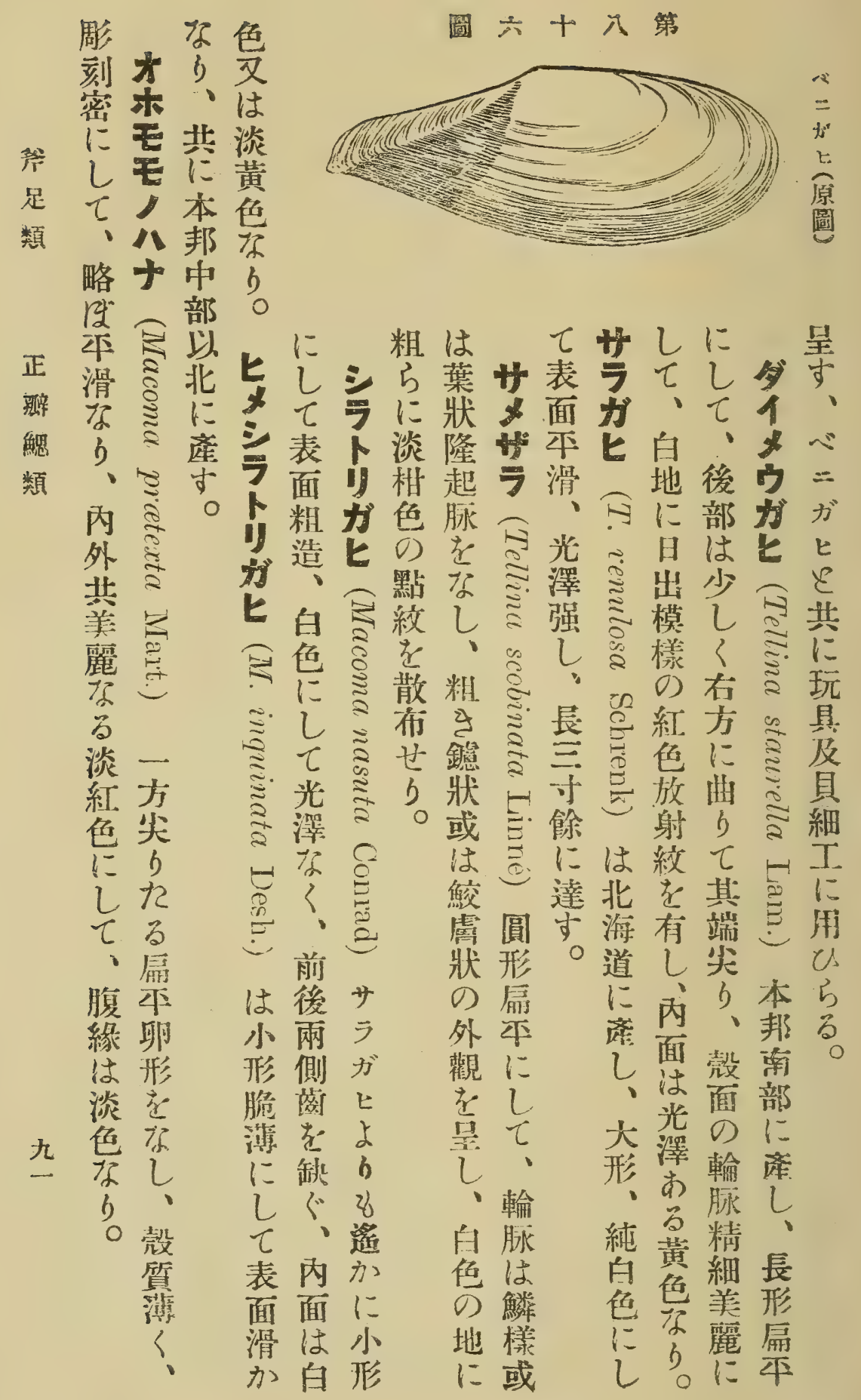




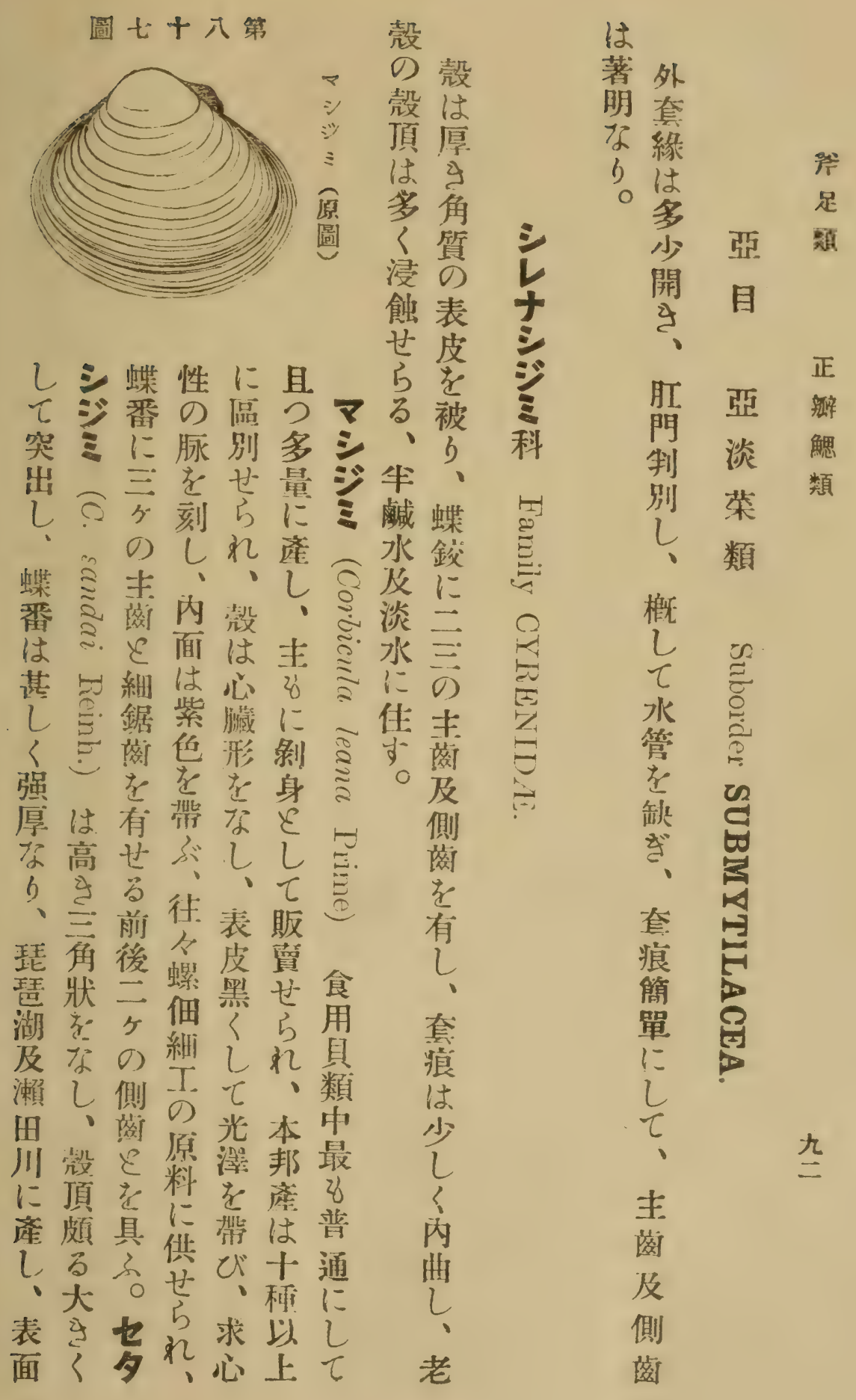




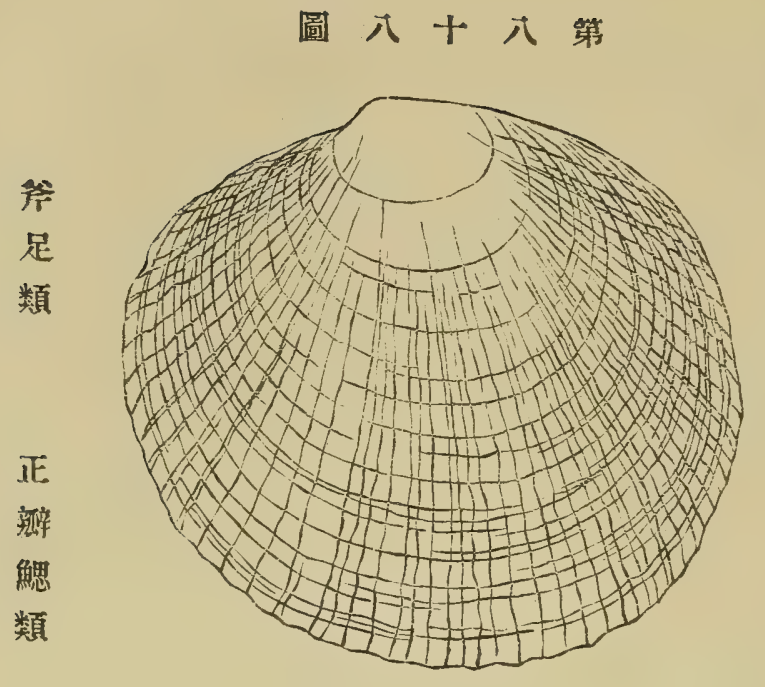

具泉积邦。宛

細色ウ、縱南りの殷

工に背橫部平侧は

にし人緣のに方菌圓

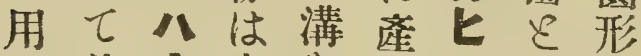

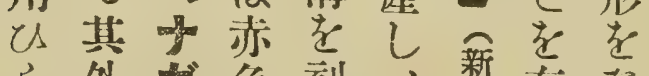

ら外方色刻、新有な

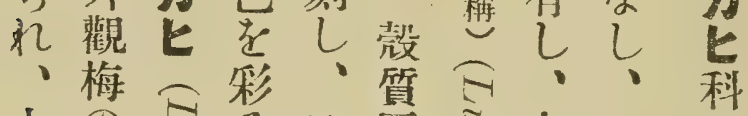

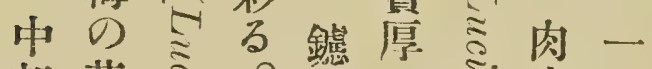

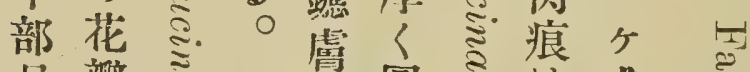

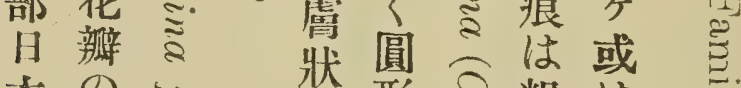

本のき形尺粗は寻

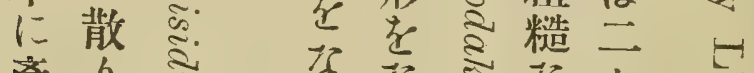

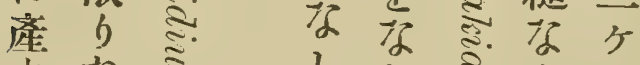

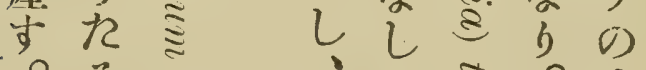

旮

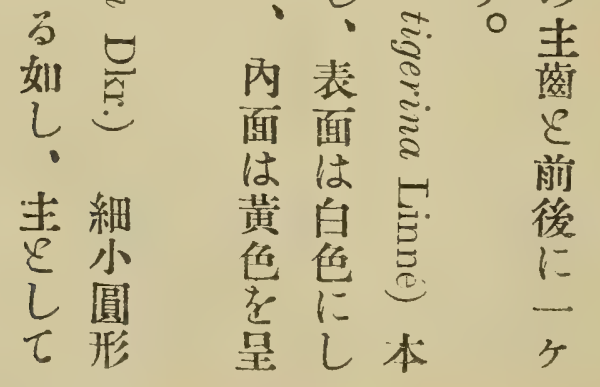

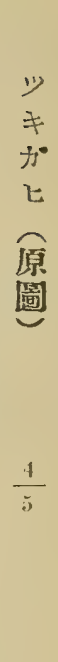

刻橙

キ

七

原

浐了

$\frac{4}{5}$

18

灰或

色湆は

に暗

L 褐

七祭色

淡表

水呈

の

泥 、

中亲

にさ都

这方

生 面

$\circ \because に$

販

殼せ

質

灌

से 1

天は

豆多

大 $<$

の 此

小種

具存

に.

ᄂ

$\tau$ 生

着 0

麗

须

当

細

輪

脉

范 
を袮㮔尚合後前之はし大表珠

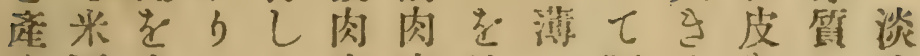

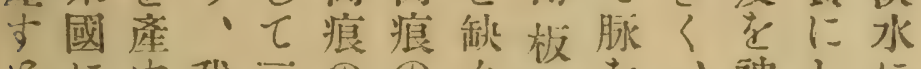

とに安我三の口ぐ壯を!被しに

云は方國学前後、狀有前多七这

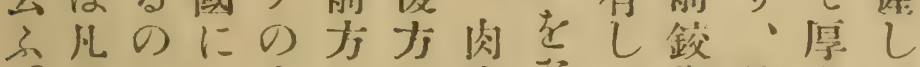

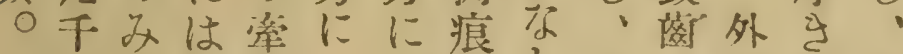

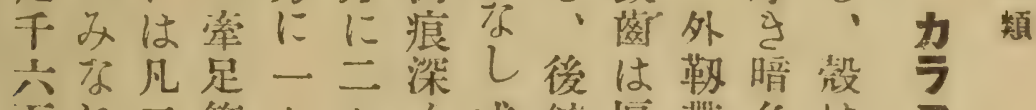

自れ二筋ヶケく或鉸厚非色は ス

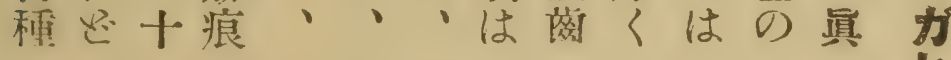

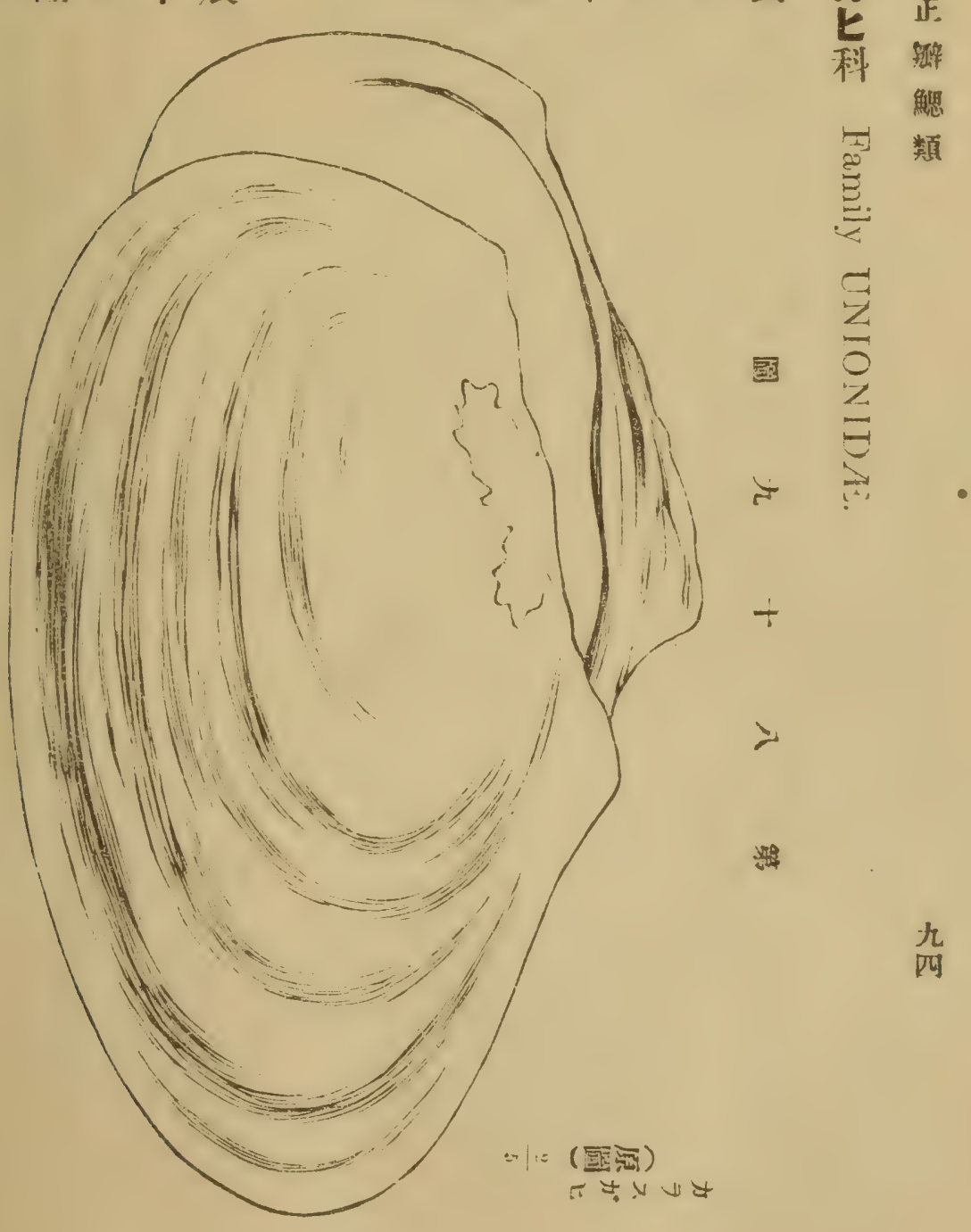




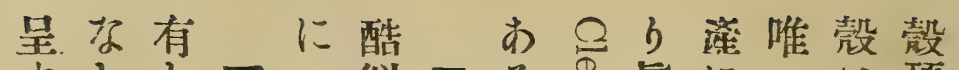

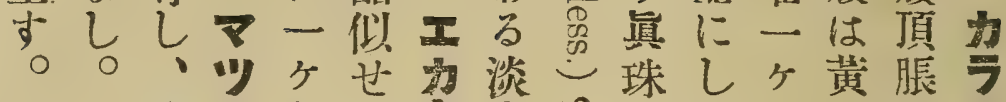

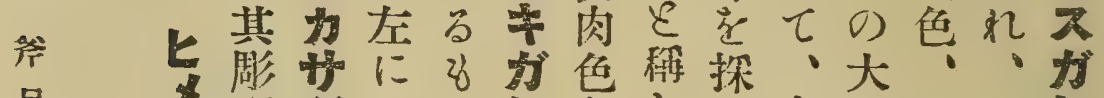

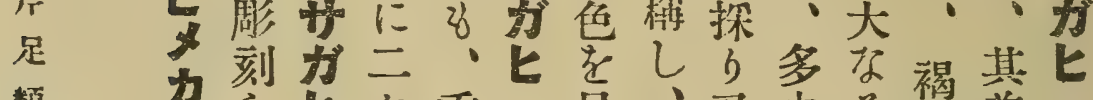
類

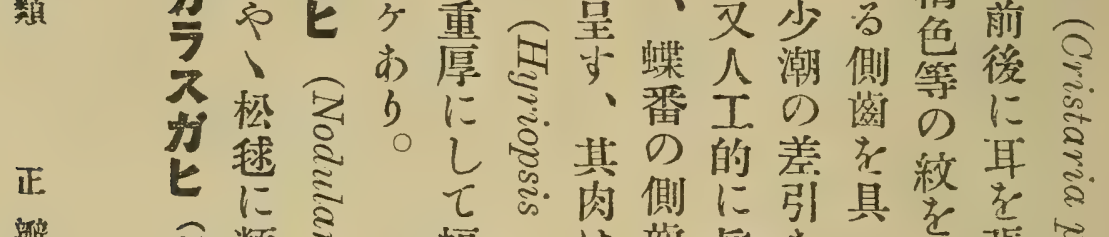

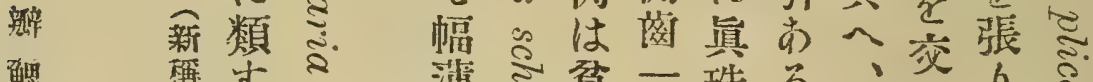

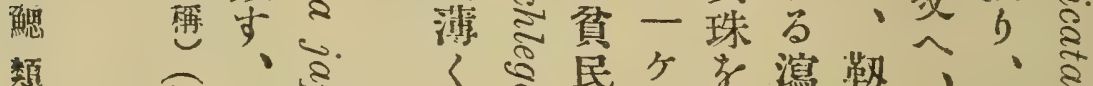

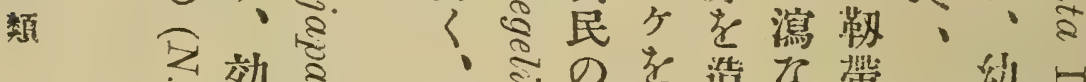

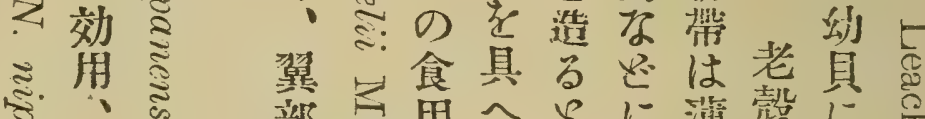

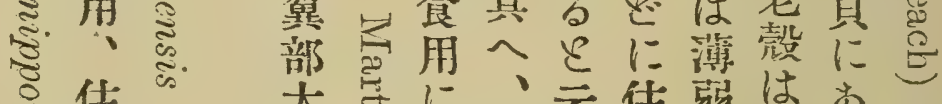

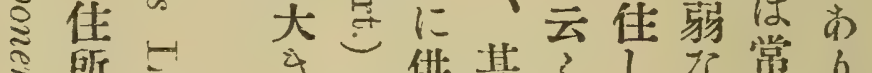

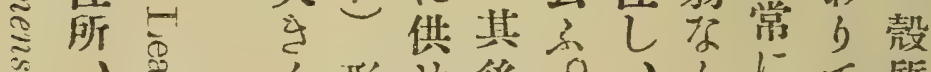

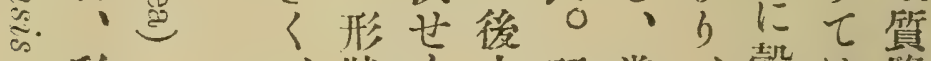
彩、狀々方琵常、殼は脆 色長蝶、员!琶陸内媔殊溥 等凡跤彩。翼湖霞面秃にに は三の色狀にヶは薪 はカ寸幽。部產浦靑てして 細ラ、は大走は白畺、長 長入表前学有当其色珠表椿

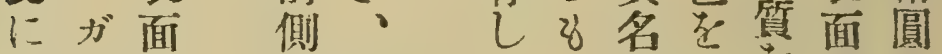

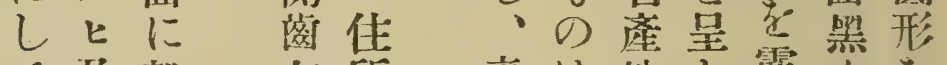
て及殼左所表は地し露くを 表工頂存、面心桑光出、梠

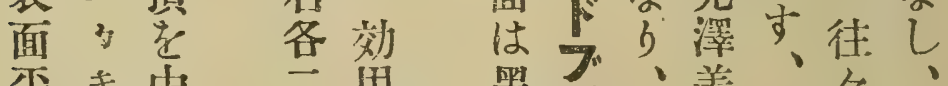

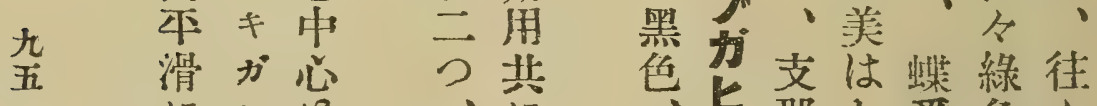

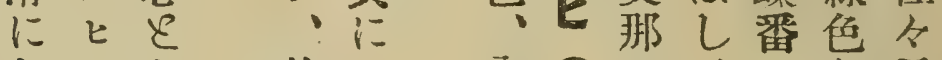
しにし 後だ内人に、にを尺 て異て側ブ面のて東は带餘

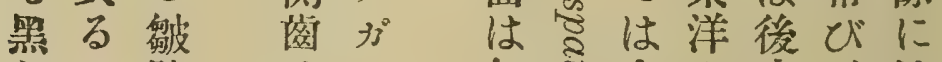
色乙璧はと紅莺之の方、達 をと老右に彩るよ特汇幼し 
圆十九第

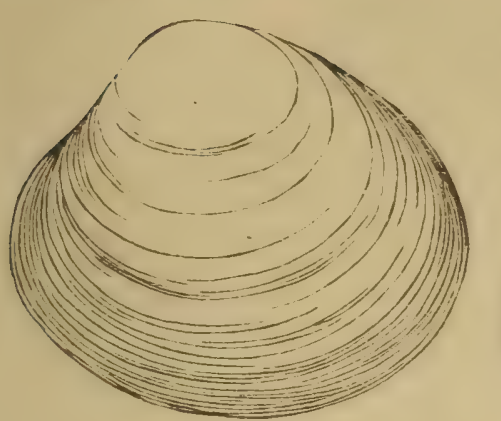

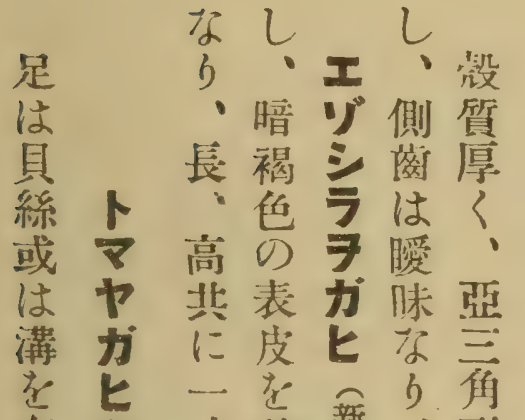

有科吋被新、形力

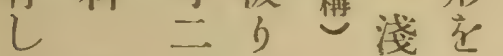

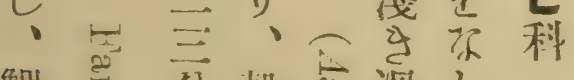

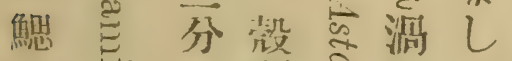

は紫、頂导脉!

大下はす方外

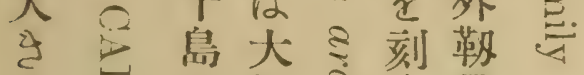

<导に抵方立业

ᄂ

$\tau$ 西领

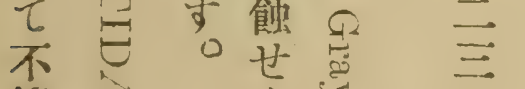

等 引运学

尔和

b

左

右

兩

殼

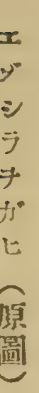

I

ゾ

三
$\overline{7}$
7

吾:

窎

殼强

內は主

面蜆

は形

白老

色㾌
党
云極北 あ澾

只以游当し力

乙道純、八

廣の黑殼

〈諸色媔言

川床品

加及丙著工類

奈北面し力

太北化

步留前

落碀方正

國告質红 解

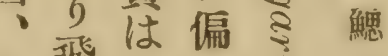

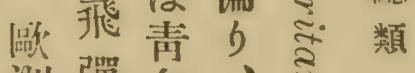

洲彈白、胥

大に又右

塺擴性等

- b淡㛂

西て紅に?

比楼考一

利息呈枚气 亞し ᄂ a

少左

万琵役版

北琶質牌

湖湖厚に

道以己二殼

に西皇枚は

等に以の長

るはて强梋

ま之具蓄圆

で走緗走形

産兒工具に

せ标のへし

せ、原、て

当本料表長

所㮔に面导

みは適は四

乙分守治寸

邑布、濢に 


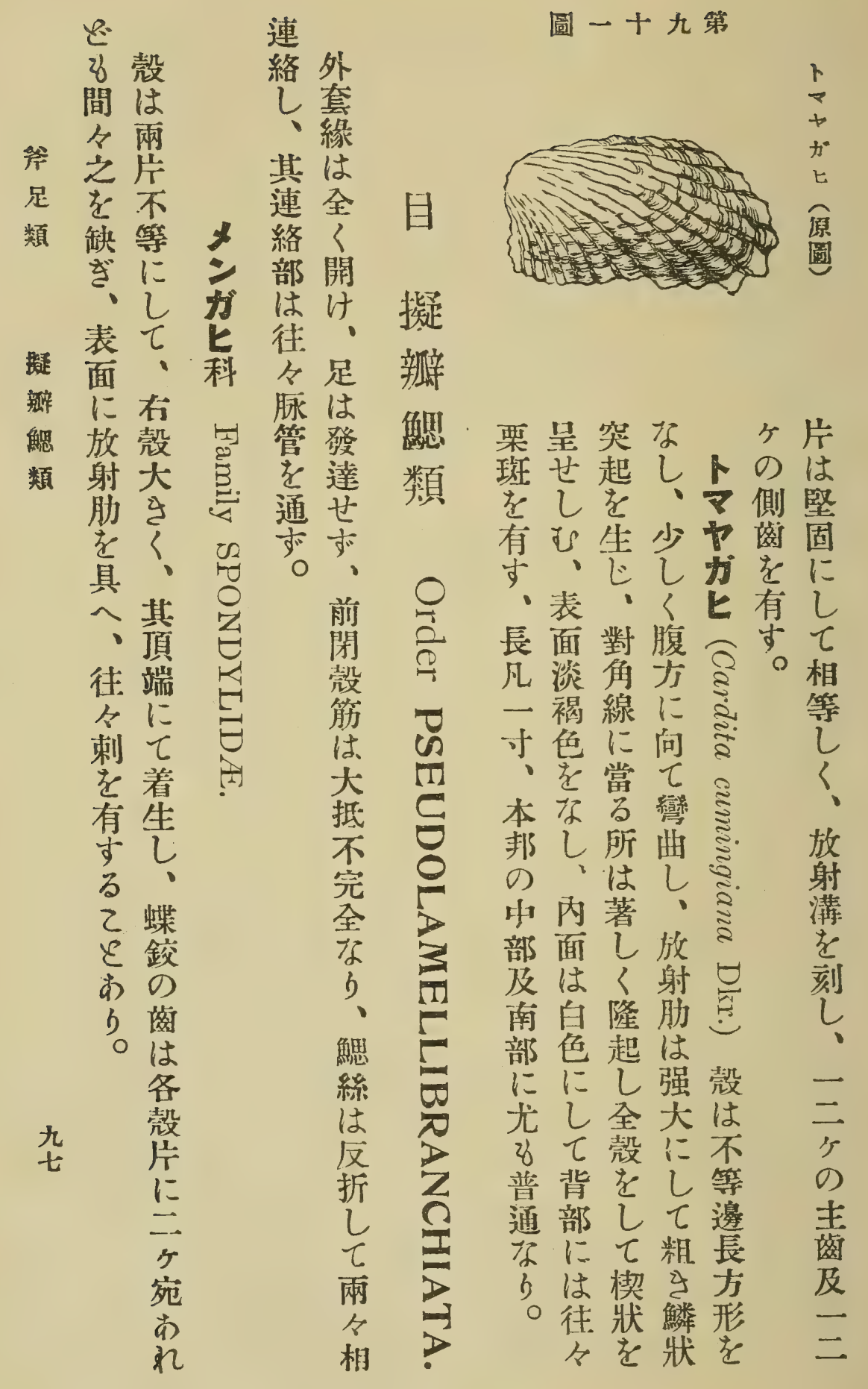


白放白年手 色射色七り に脉のの ボ しょ地桇タ て りにくンヒ示絹面の肳

焦

L

$\tau$

雨

側

開

開科忽学繁有著

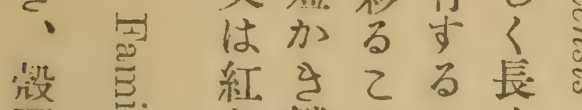

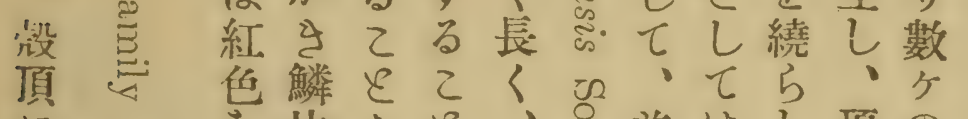

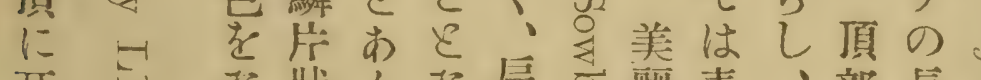

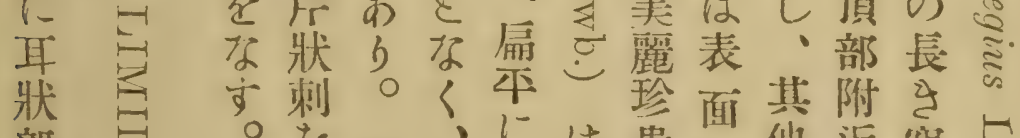

部

筫

具

蟝

鉸

$に$

茼

品

两

布

に

痛

形

○)

軟

骨

坑

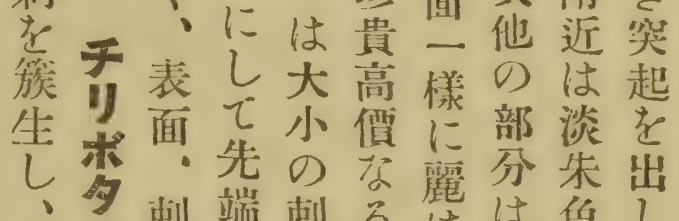

整端刺るはは色し殼

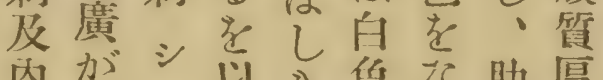

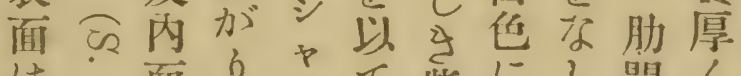
は面只另紫に乙間々 紅导和不ジ古紅微線に

色綠不規事紅紅部は略

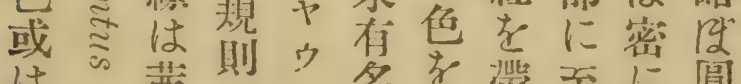

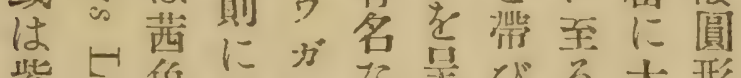

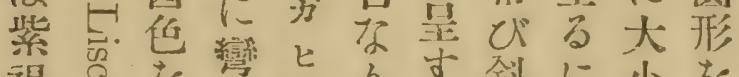

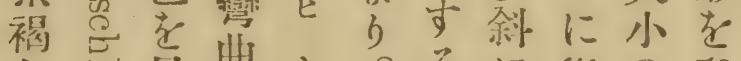

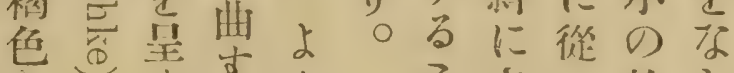

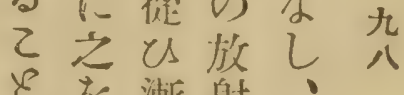
是は・シ政

元大時ヤ多 、抵とウ数 内歪しジに 面みて は・灰"
と桷射

あ)矮名脉风 与、鮮を草 朱刻兵

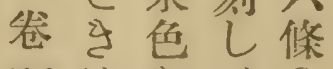
頭はを、の
路 足 類 龊 就 解 類 
に概

三儿凯 十ては

餘耳着 㮔狀生 足を部或 類產をは

疑

解

鰓

類

主具離

○全生

吾

蝶

鉸兩

は原

短不

㨁等

に

政

$\tau \tau$

$\therefore$ 分

待放

分射

分肪

閏考

世有

与

數

5 两

の䩲

不帶

完は

全政

桨頂

九 万の

洛 [门

を部

有内

与

南

本 3

邦、
圖二十九第

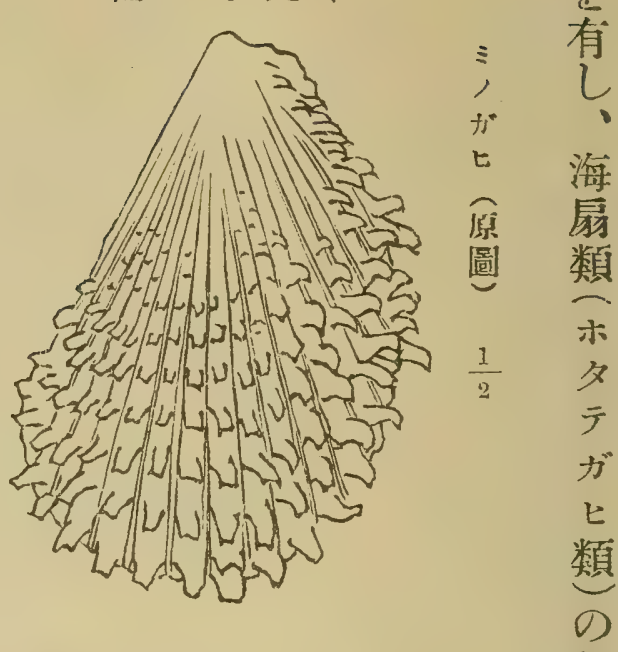

如

二稍鱗的にに規略

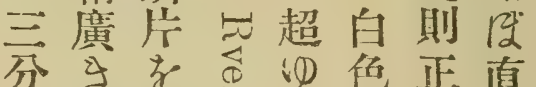

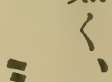

㲄

間缺—当度し角势在

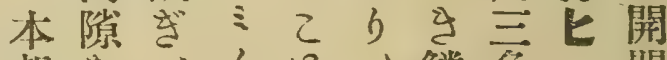

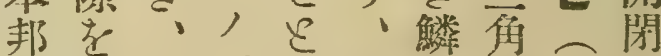

中殘左ガあ中厈形㣽し

部乙有上马部狀老匹

以、の。以等奌水

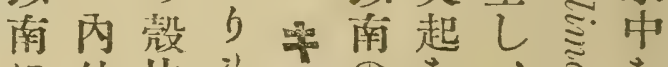

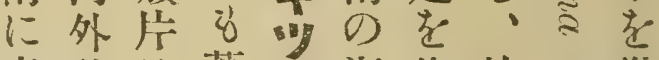

產皿は著子海生放上. 進

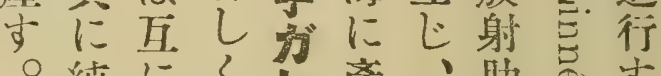

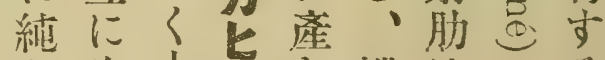

白吻小乙蜲は当

色合形霰覆 2

に世に時の虔國气

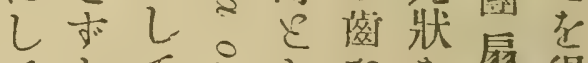

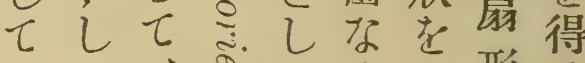

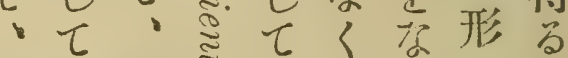

長前彫吾は・しをと

凡後刻它長肉、㾌云

一に細点四外稍し京

寸稍密完讨共多、。 


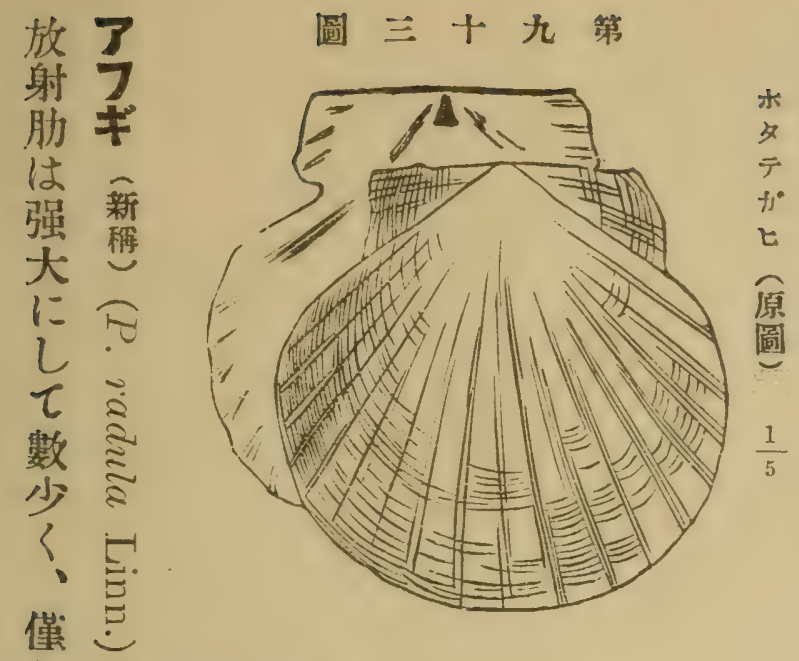

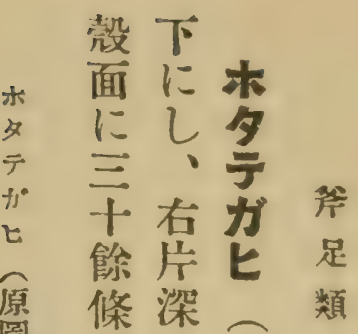

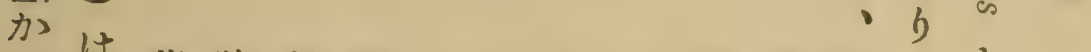

には紫狀數略のはに彩其凯、㞦

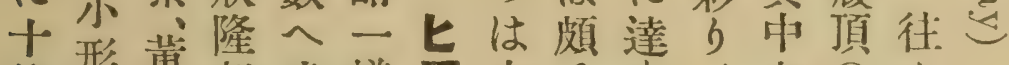

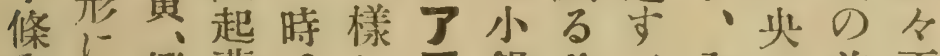

内! 橙溥とに 外乙等板し脹キに味北面大後片の

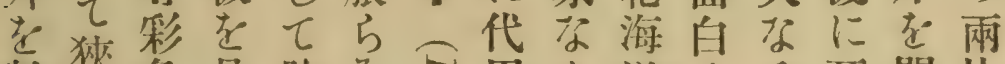

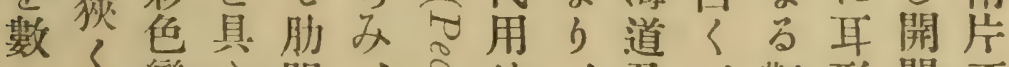
乞、戀示間、运世!及、靶形閉不

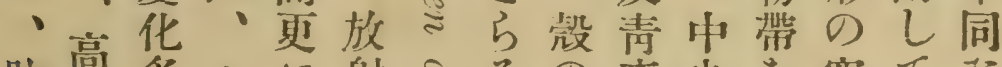

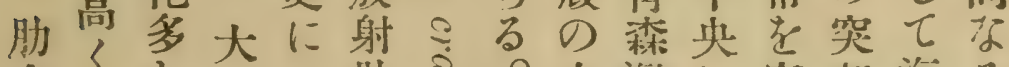

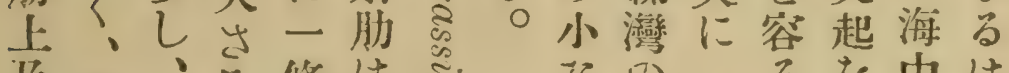
及前、凡條は空沓の一るを中は 肪前中五の判号名大!具を力

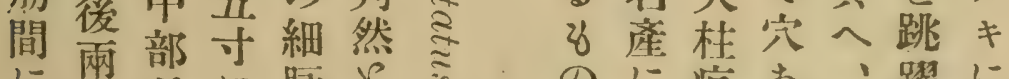
に牛日に脉と被のに痕お、躍に は本達をしはしをる蝶す似 更少にし有七少化、有番るる

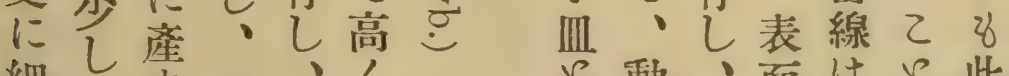
細々す淡りく動、面はと此 放形。淡渴三は物㲄は值あの

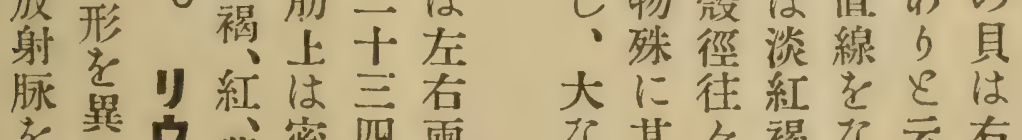

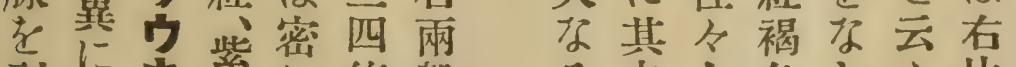

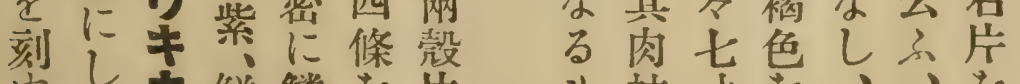

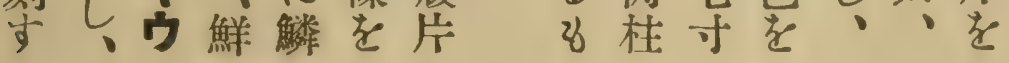


殊し稻叫ガ徑㔔脆黄則。諸带

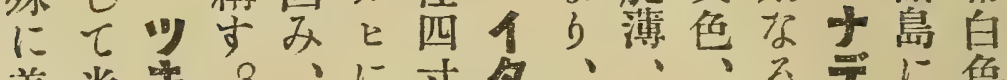

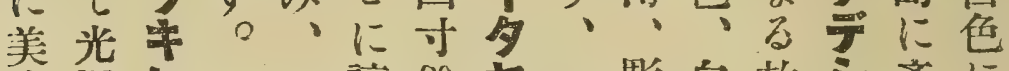

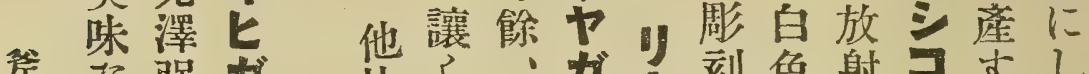

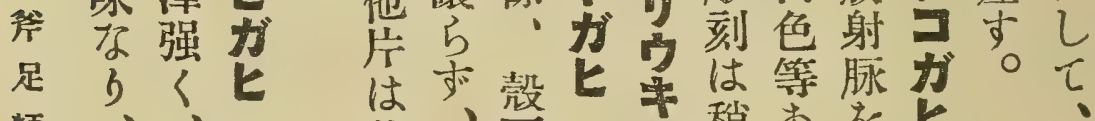
類

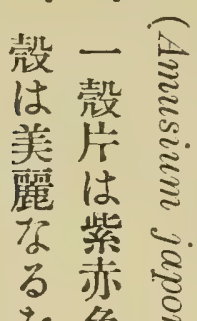

類蛋色

以. 考

七应引

往し $\Omega$

々: 苍

IIII 他 $\stackrel{\oplus}{巳}$

ع店

しは教

乙淡侗

販黄灌

賣白く

せ色、

ら原

る

其

基行

は扁

食本

○角

に

供、

し 表

面

肉平

柱 滑

はに

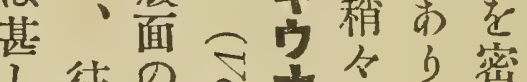

〈往放ミ滑七密

脹本射 $气$ 美刻

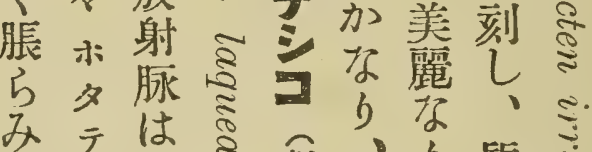

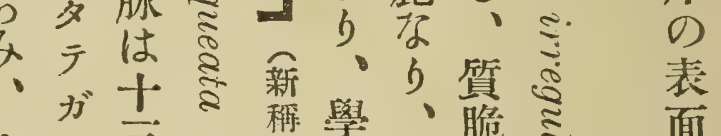

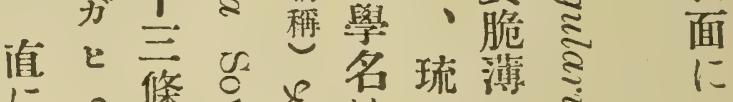

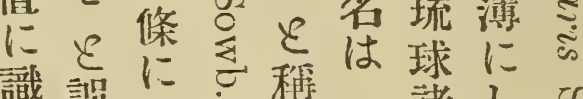

の

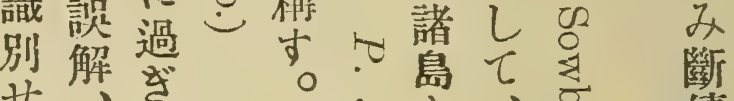

せ热木

る䛤、夕

よ流續

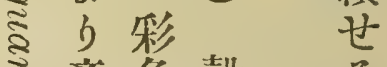

產色殼

宗斑は

古点占

來れ南に

具尽海似。

杓改產穴

子款出

用管肉?

क 万絞—

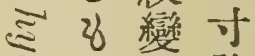

の化許

计多b 狀

扇の稍

ら本美々

る、に味棈

、乙尔圆

俗て 獎

空圆、

-1 牀、卵

㤩鮮狀

る

栗

色

の

に却它

构七尔

子中标

存办老

とし示尔

稱稍学し

乙夕褐㩔

大色本

狀

彩形!に 寸

色に紅し 五

多色七蚠

樣て、、

具央夕!美一紫不琉

と部于長麗層色規球 
圖 四十九第
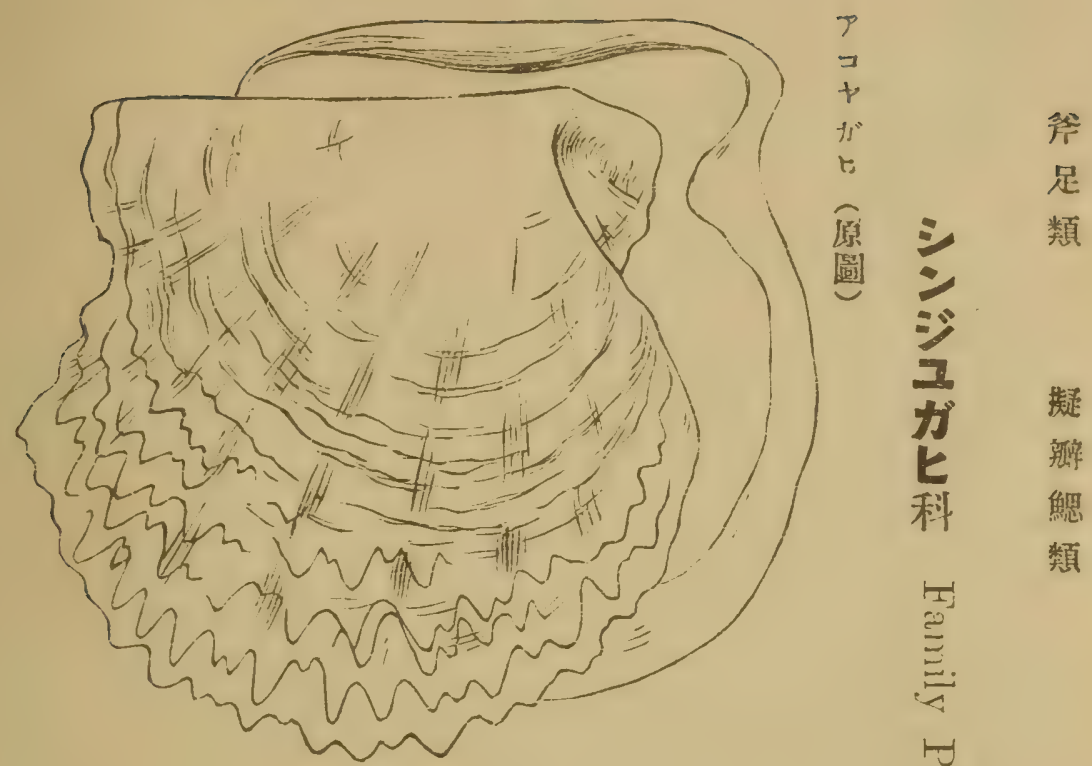

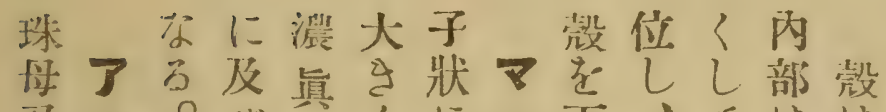

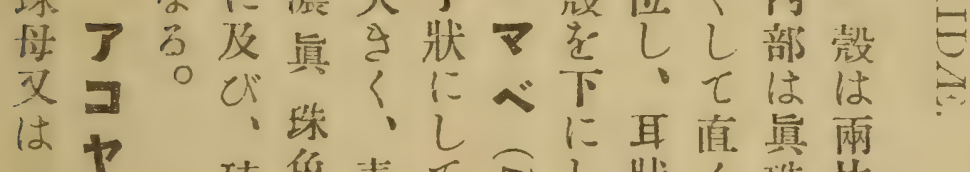

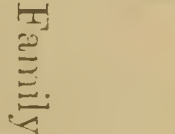

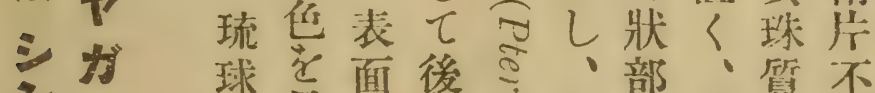

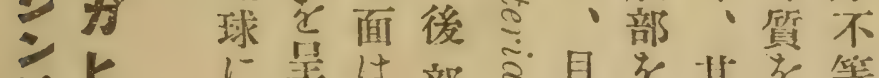

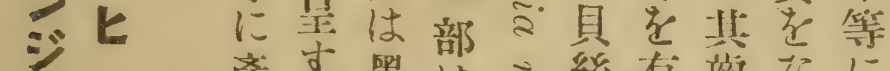

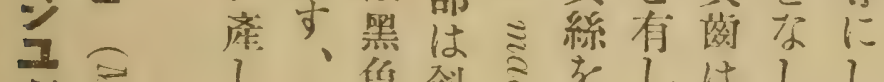

ガミし、任䣄壳しはしし

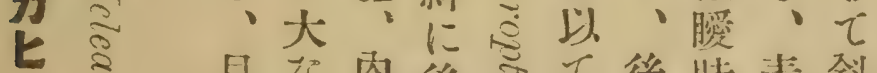

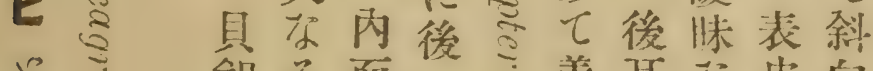

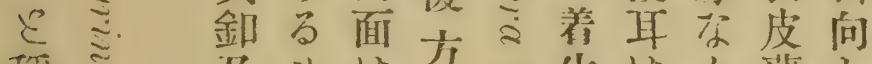

穕芯改に司生はり溥し

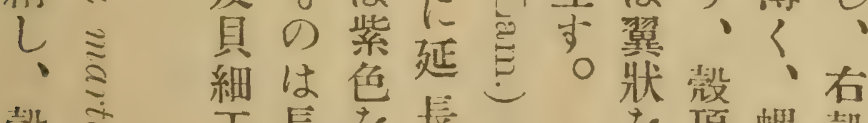

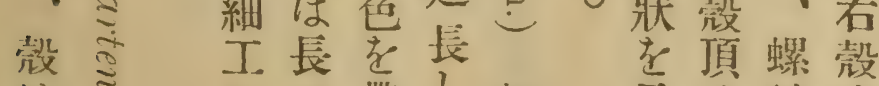

はきのの带し放呈は鉸小

扁它原一び!は方前線さ

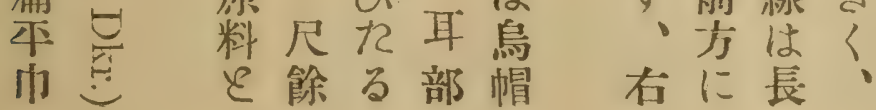



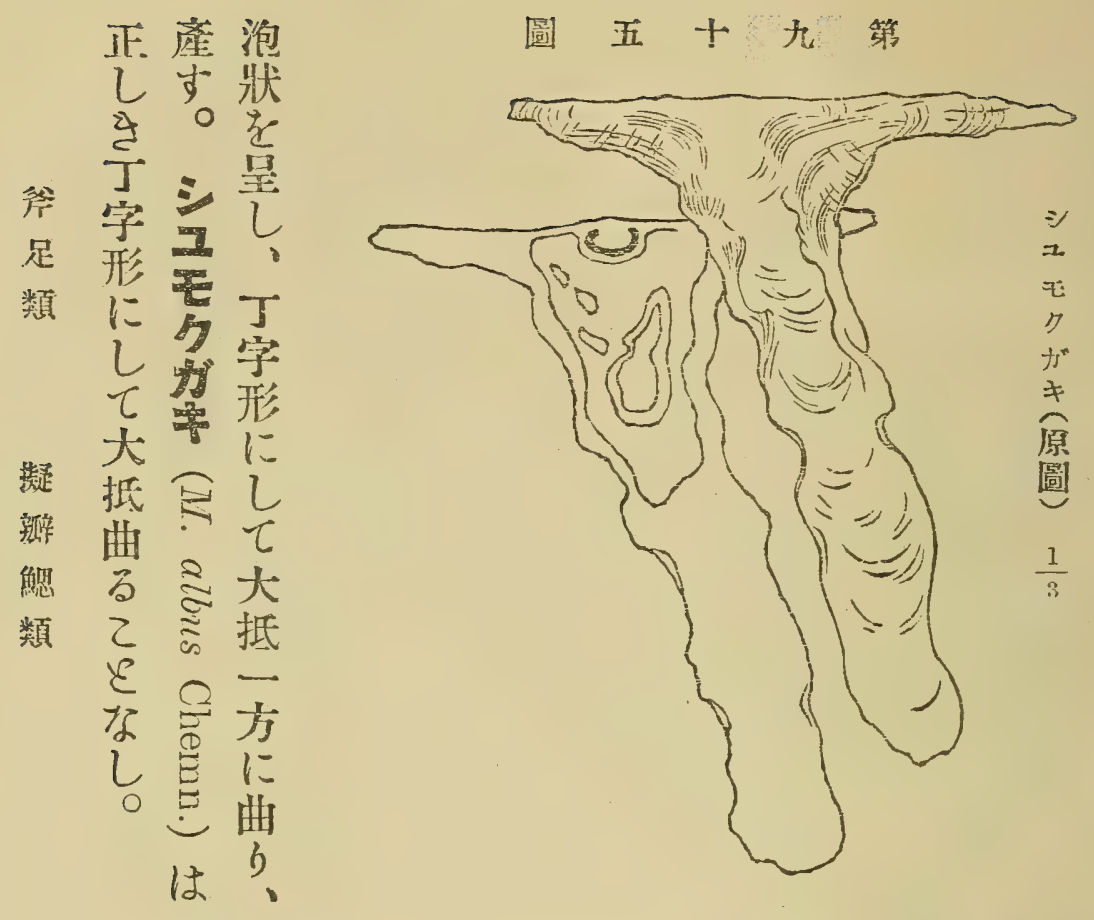

㐫殼尔用のる相荅本結蝶着

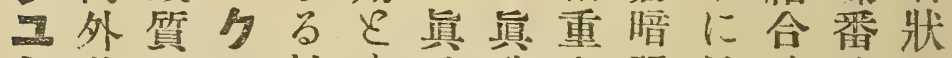
基为材主珠珠示褐足世は。

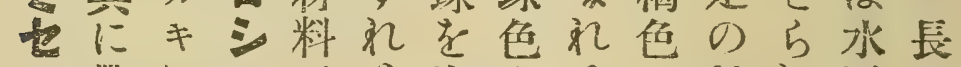

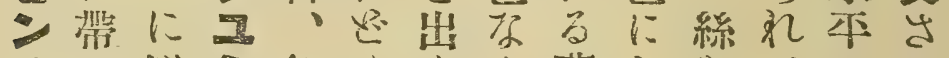

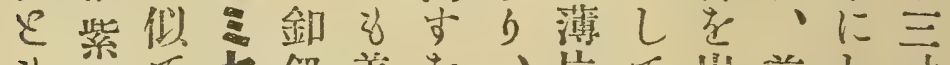

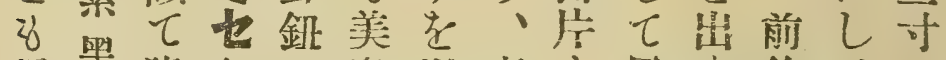

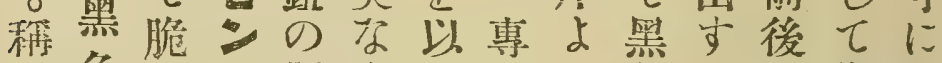

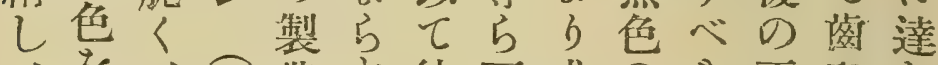

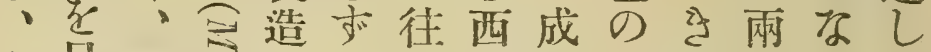

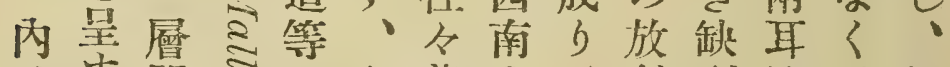
外生間㣽秀養の・射刻は・殼

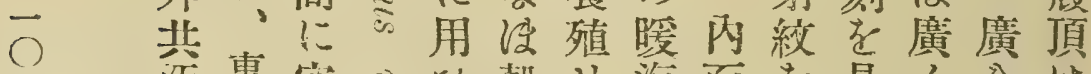

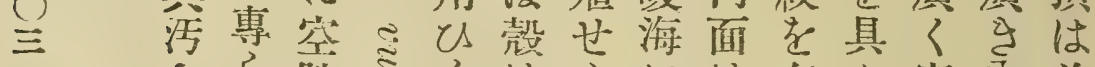

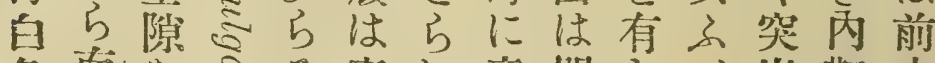

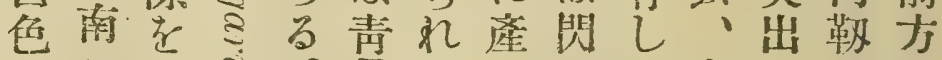
に部有空。具、し光、表し带に LDし の肉、橴表面前を偏 て海て递優闌皮は耳以し 、發导故食等次は帶のて 
圆共十九第

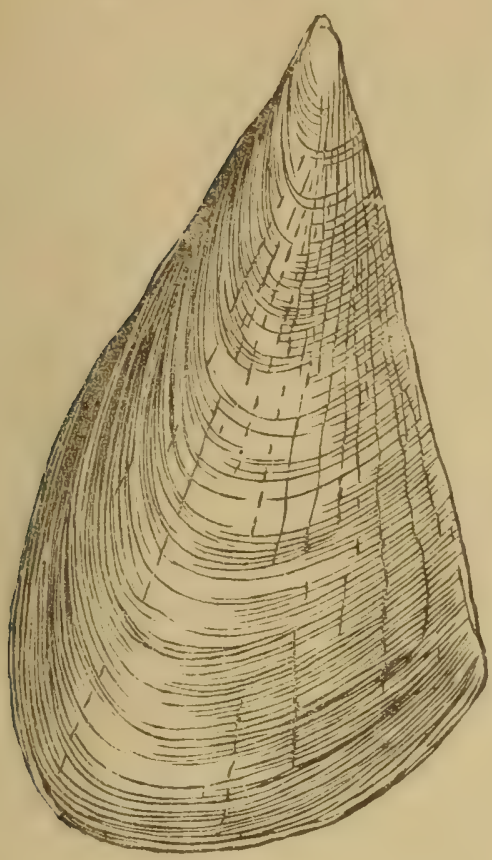

敖云は類て肉甘し稍 はふ往のは杜味て々 紐。時具肉尤多暗㨁

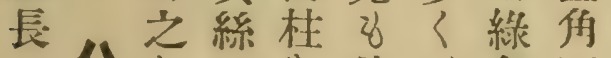
に心艺は袁美、色三

乙 以絹罐味汁华

てりて絲詰なの衔形

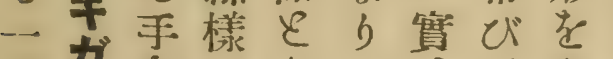

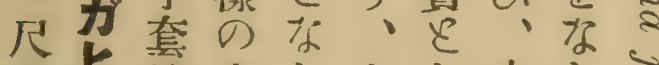

飭七等光し九し肉し客

に名澤て州て柱り

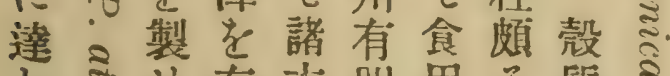

し合也有方明用方啠

○こしに海に大脆

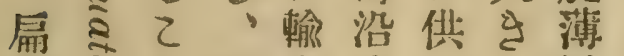

本 2 外出崖也人微运

资あ咸すにら!透

るこ りに、文る肉明殼

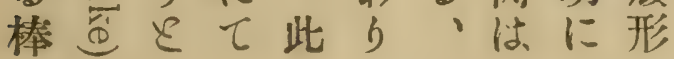

る 强

if 2己 殼

の具は

あ 絲 楔

りは形

气大老

云 想是

ふ。尚

0 三人

重左

の右

箭 兩

肉片

よ相等

科

率

足

類

b. 2

网

款殼

圥頂

のは

中 前

央 端

至

附 位

着し

す

、後

外端

國は

產 截

に切

は狀

長 艺

प 75

$=\mathrm{L}$

尺て

に開

達 Q

频䟥

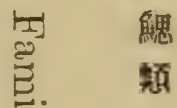

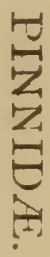

寸 


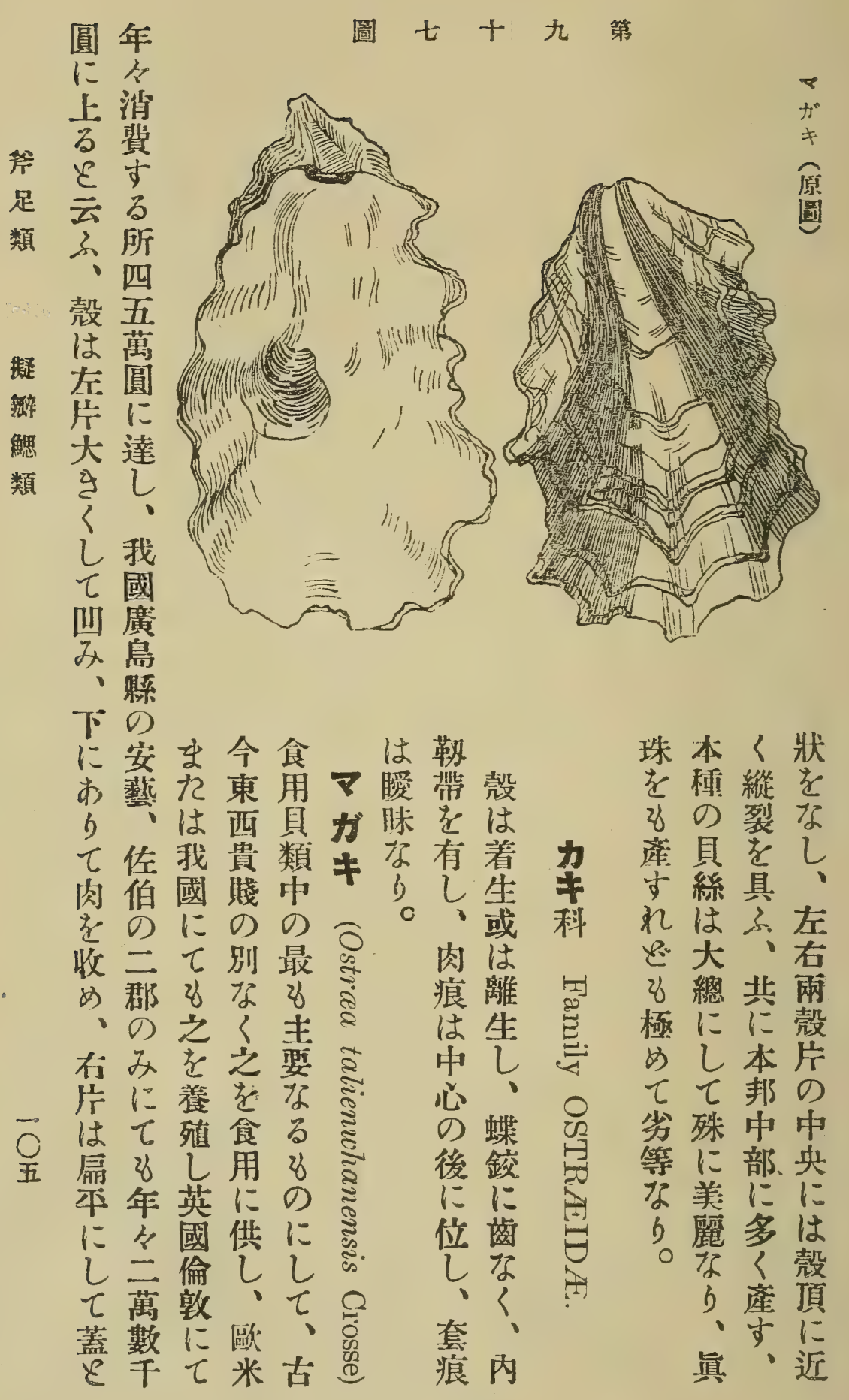




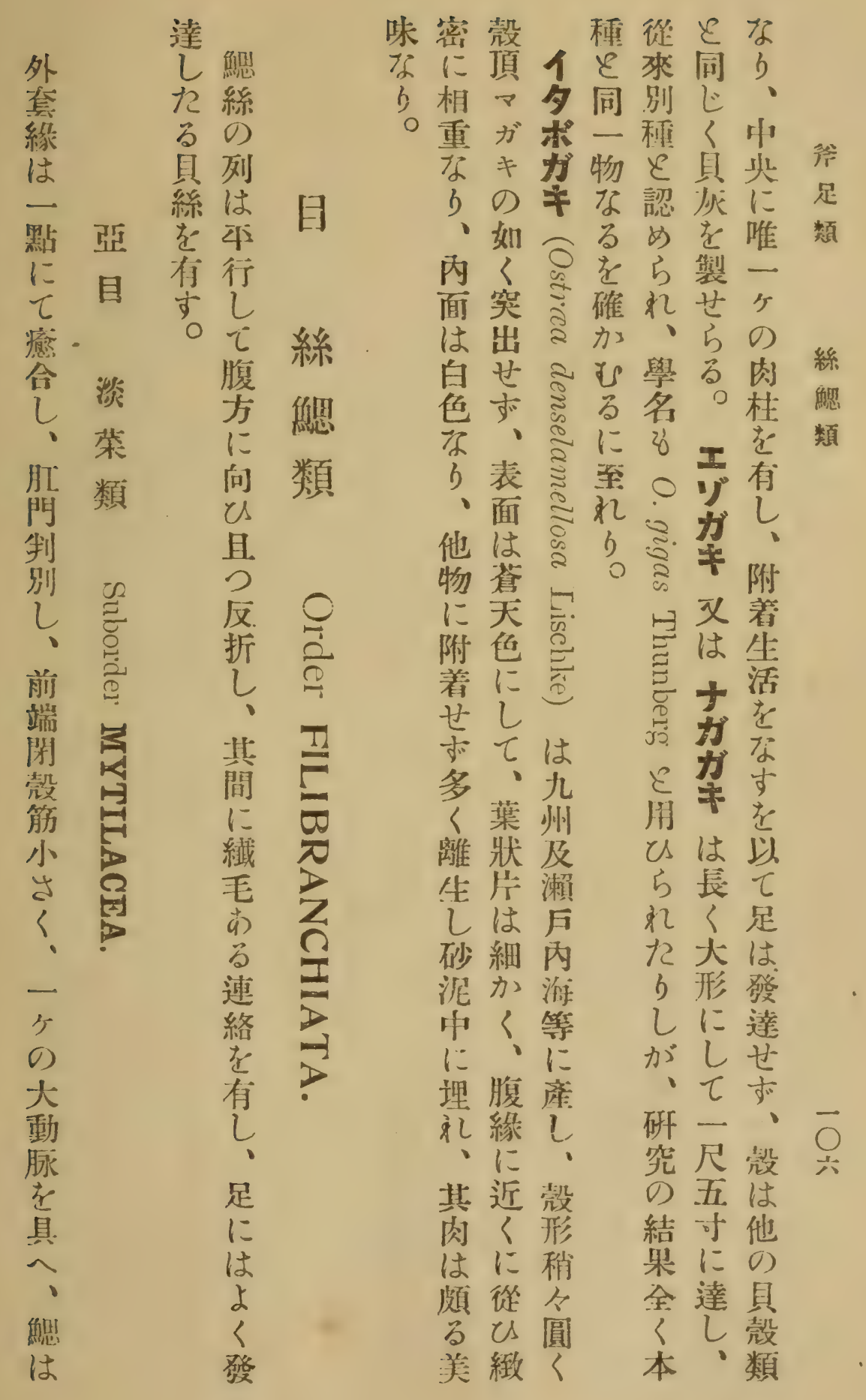


後く着絹の契をし葉

方七小尔生の表形１生、殼間

に心形出し如皮を加に内は連

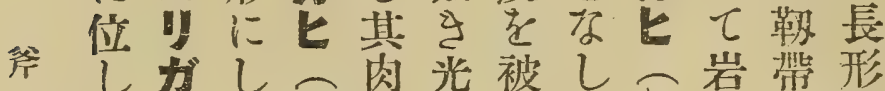

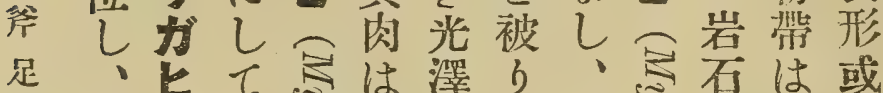

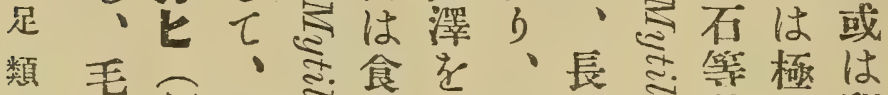

㤫

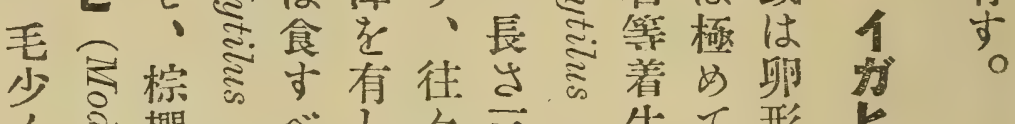

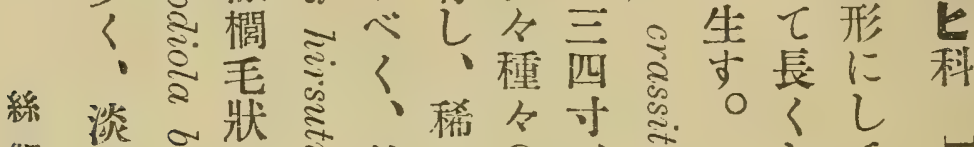

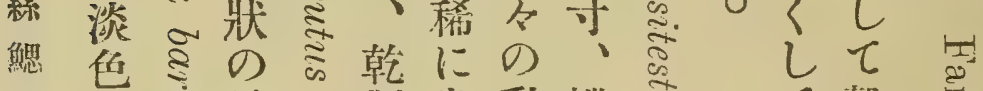

類にミ長山製劣動. 蝶气

乙毛总し等植番上

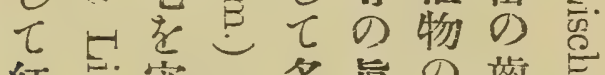

紅志密多畺の茼芯

色怘生前少珠着小追

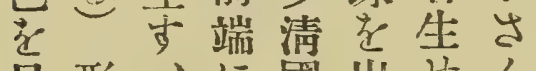

星形、に國出芒人

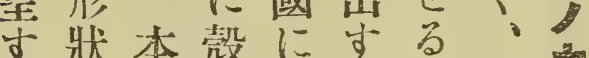

○芚邦媔輸、乙外 大宋出㾪と鞀

さ部具守々 引帶

少に人。本りは

ガ產、邦、長

七专形諸肉了

に。狀海面し

類彩にはて

吉色產紫撜

る 共し紅頂

is

、綠 の

淑 首

蝶は品

鉸 前

に力四

莮に气

梦位可

ᄂ?

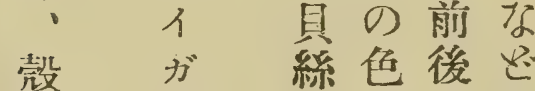

㣪表

肉皮

痕厚

はく

大

形厂

に褐

し色

て

瞹 是

滕 し

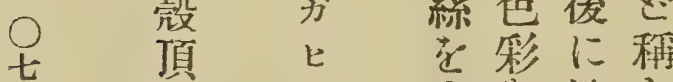

はに出を涉し

前似

端者

D if

少著物明褐擪

乙黄 b、動纎

b往

's

て 、殼物維

他 黑質は狀

に裴色く絲な 
の

連 外

結 套

功綠

<開

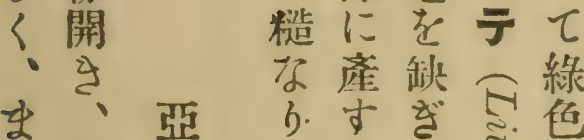

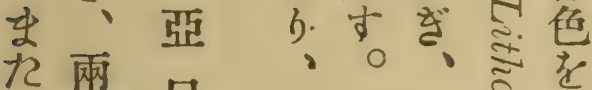

水閉目沓三岩䱏彩

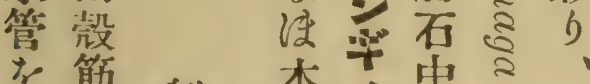

筋㦼本分中る。

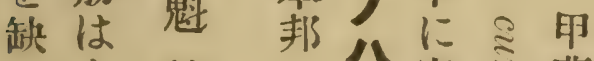

ぐよ蛤に穿き斐

發類は住文絹

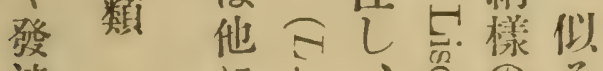

達に、吾のる

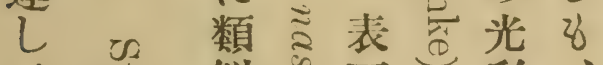

$\therefore$ 导似面彩

心总の赤是毛

臟㤩四栗は放龩

は 五息色圆短

二. 界種学

こは形

の

大

動

脉

老

ᄂ

䱝

は

分

離

ᄂ

鮕

絲

間
產長し袁

字大留

に丙し

乙面

$\tau は$ 七

長荟 ガ

大紫り

凡色

四老七

寸呈に

守類

㻗、生

黄長る

色凡

に二長

元怙刑
圖八十九第

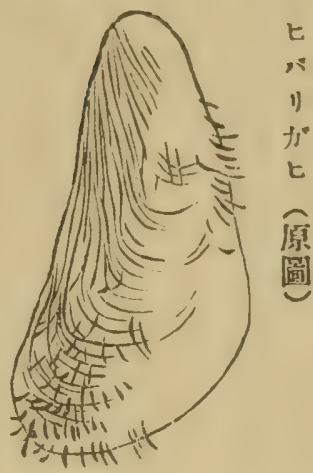

齐

足

類

絲

䚡

類

其 本 殻

クの滑 頂朴

ジ他、は

にヒヒ

綠ババ

\section{力 \\ 然"}

をカ ガ

了彩七七㤩 尖管よよ

$b$ =

施

款 藏

頂

位气

内

面

祀

溥

공

隔殼

板 形

轿

具

ก七

b 3 :

if if 小更密

ปに

〈後

長方 :

一に

寸位

許 ᄂ

褐殼需分

色啠 潔

に薄形

しく、㕝

七・呈

緣表虽 

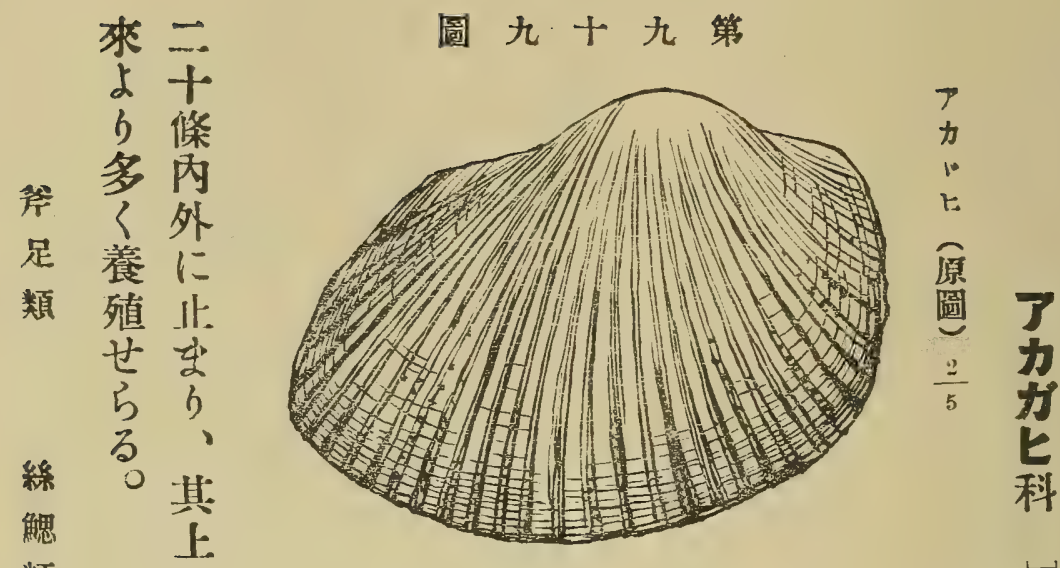

類

に

結

節ハさにる足刻表さ同

狀 1 短類美は目皮吕了形殻

突攵く似味長をを四わのは 起飞、世及く有被打渵强

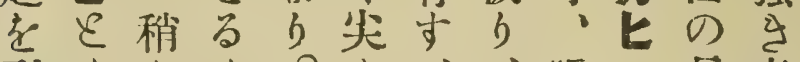

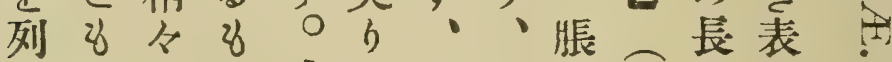

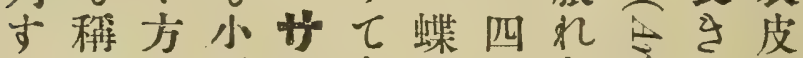
、乙形形儿浾鉸十たミ—老 肉、にに术色線條る心。列被 のア近しウをは円心孛をり 美力して乞呈直外臟交有、 味

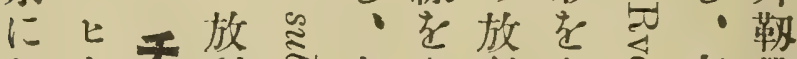
しょ”射学肉尔射采套带 七 肋密はし肋し痕は 瀨 \& 0 尽鯰、を、多明兩

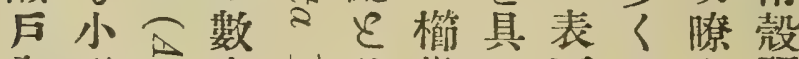
內形。少共落へ面東尔頂 $\overrightarrow{0}$ 海に字く点狀、は海り間 及しミ比芯紫の其暗に。索 九 $て$ 較赤細緣褐產覆 州、的は色莮邀色し U 等放引にアにをにの、 に射志殼力し具藏鱗殼蝶 は肋®の・てへ狀崖は鉸 古には長し頗、の狀長は 
圆百 鸴

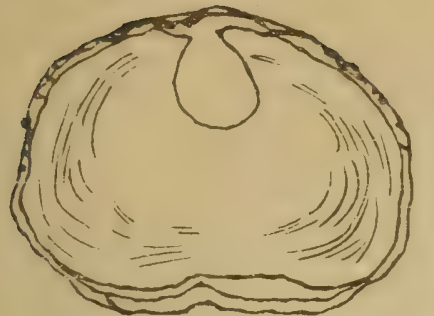

柴横 就

あ 贸

b 質

且。は欌

鿰士つ極は

、< 三 不め㨁

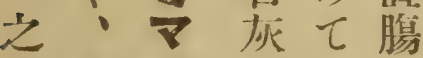

よ磁战化小の

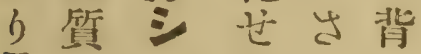

具に八当々而

絲し科

tr

絲钤位

出下武には柏

し殼异よ牰、類

ての

他鈠的て狀動

物顶空附范脉

に附龵着点は

着近忌世艺

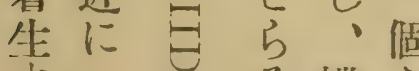

古一当蝶尚

○個

()

媣

y

切

n

込

学

俱

ち
山向真刻モ㤫表か

ミにへし之皮少

、配、、元沿在カ

放毁細可岸被子

せの毛一石 5 足

原呙考垣、三類

娄记外有等栗

其せ气河色

一にっ今間 のき

樣白厚的结毛

欢色尔具を解

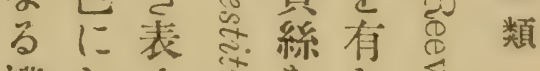

亞溜し皮芯をし过 淡てはも出

の. 形 栗表凯政面狀 色面綠多青稍 走はに炡數白分 咥栗遺質楱色下 古色存厚息老 るの方く生旺や

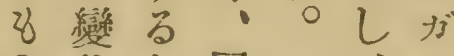
の化走圆、七 亦汇常形蝶に 巳少富とに鉸似 力め生近部当

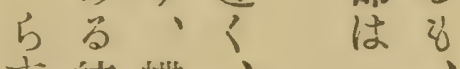
和絞蝶、 㩐番放直放 在に射線射 有は狀を脉 ᄂ二存疗微 十な細 大個过多に 抵丙当數し 生外淺化 長 D多細、 線 細 細囱綠 口喵㩐色 


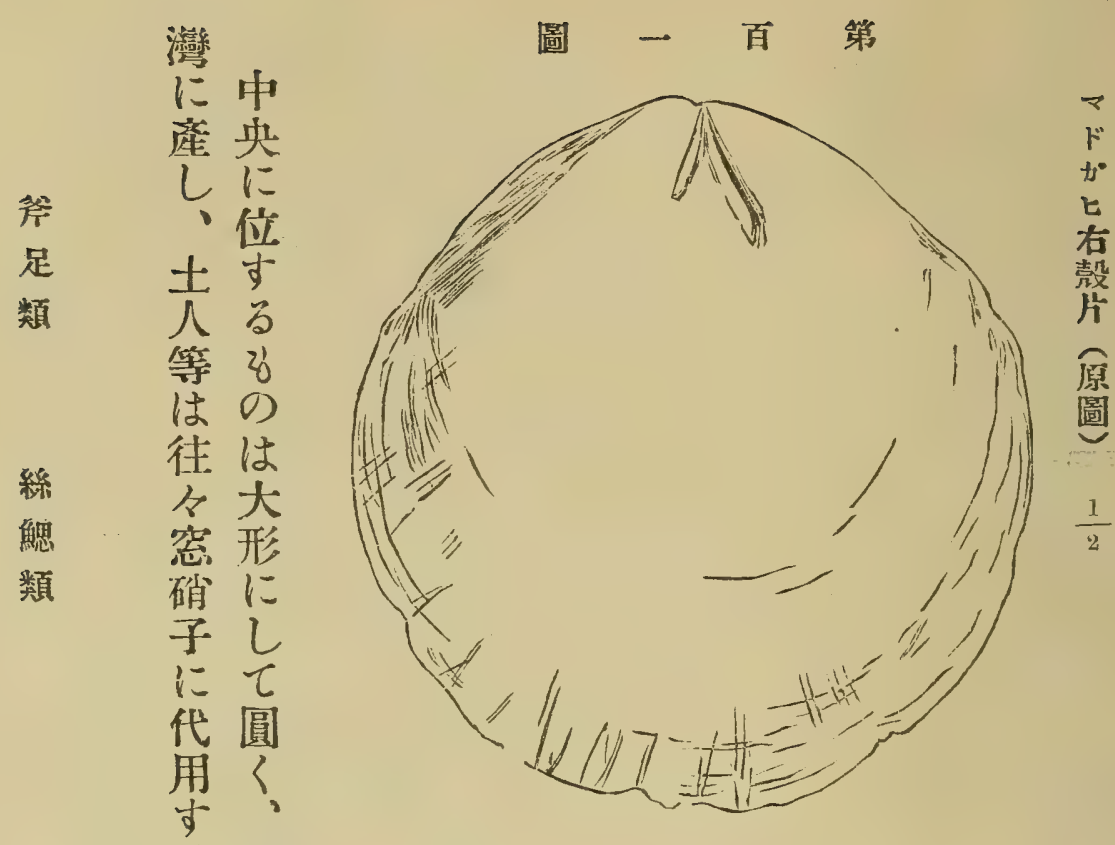

其

云前に右二雲唀附に刻淡溥

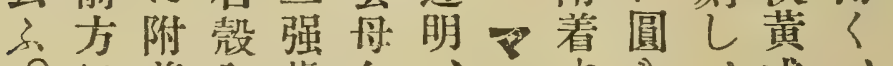

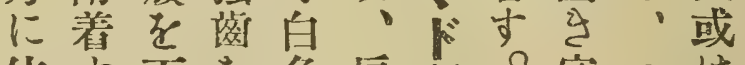

位专下を色陌线。空他は光令

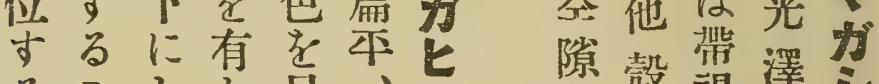

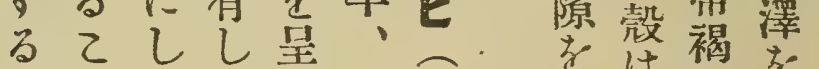

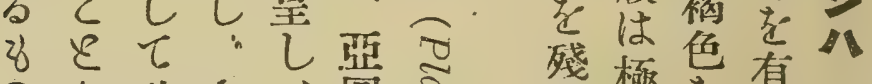

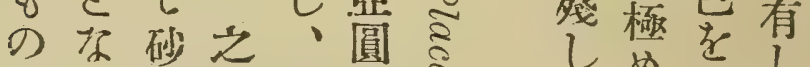

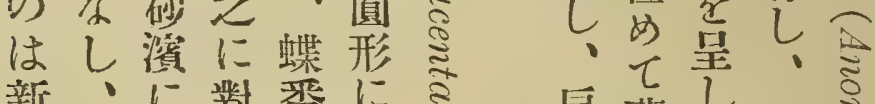

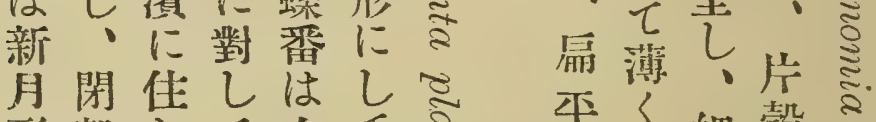

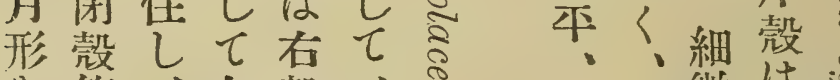

を筋、左喏、急

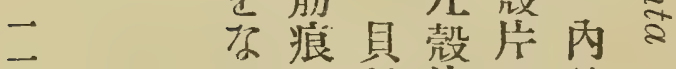

しは絲原に外吉.

て三走思

小重缺二字纪

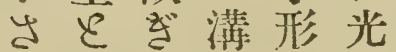

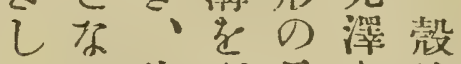

与他刻長あは

塏、物し短当半

本反微は圆怘

滑曲泼形

に装に。

乙狀的

款放记选

他頂射脹

物附豚和殼

に近を、質 


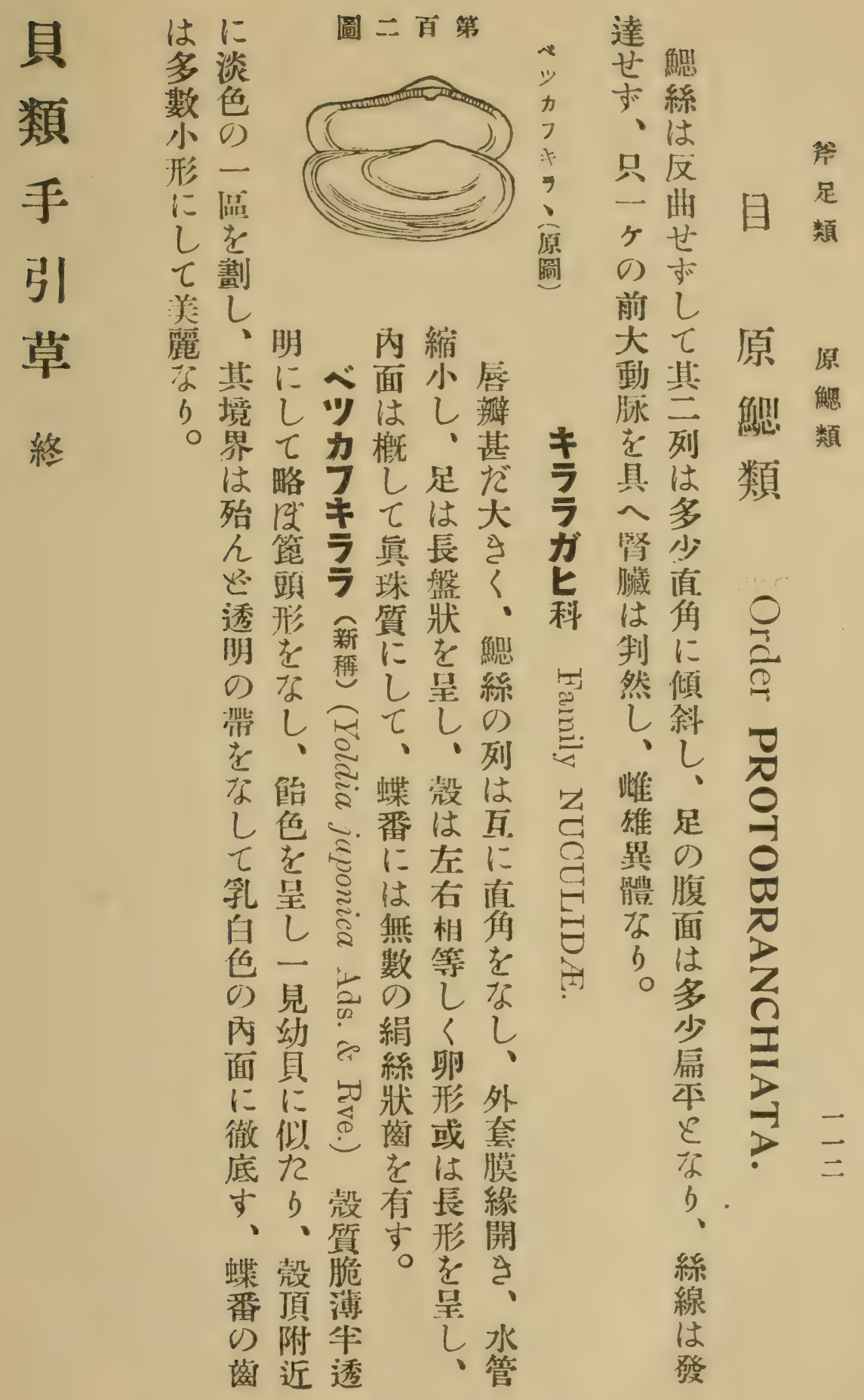




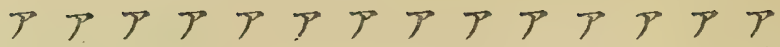

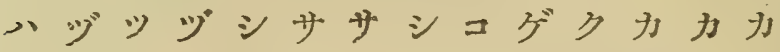

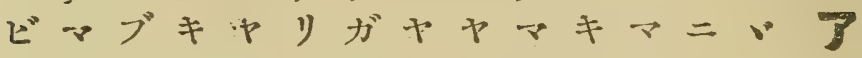

$$
\begin{aligned}
& \text { ウタガガ ホガガキガテジにの } \\
& \text { タガヒヒ ガヒヒを ヒガ }
\end{aligned}
$$

和

素

引!

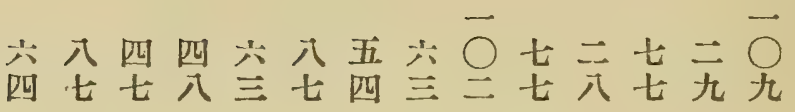

蛋

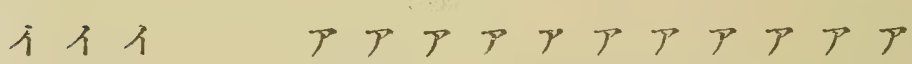

シシガ

マダ匕 オガレレムタがラムヒムブ

テのヒタガシブヒハガガシネ

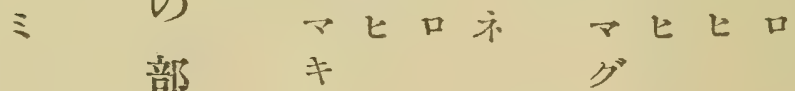

部 $\begin{array}{ll}キ & キ ゙ \\ & \text { グ }\end{array}$

$\overrightarrow{0} \stackrel{\overrightarrow{0}}{\mathrm{O}}$

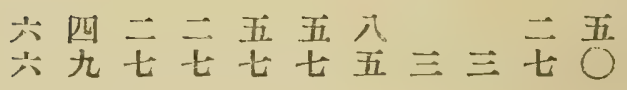

シウ不イイイイイイイイイイイイイ

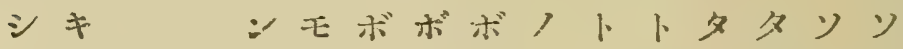

ノッ゙すコガヨソキカマカヤボ二ジ

ツ、の オீヒフデサヒキケ少がナい

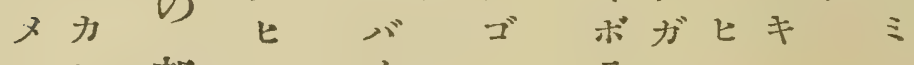

一七部不 うを

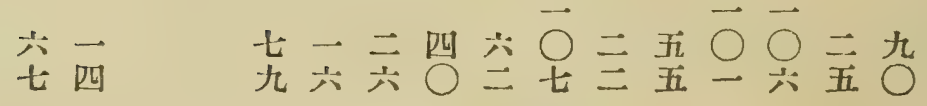


エエエエエエウシウウウウウウウウ ウ

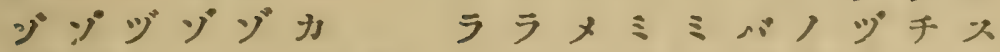

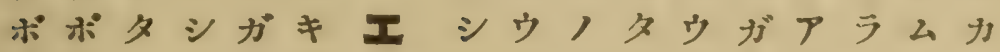

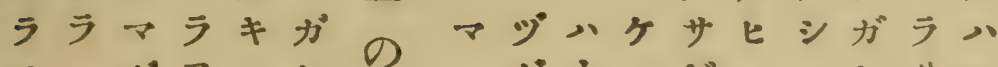

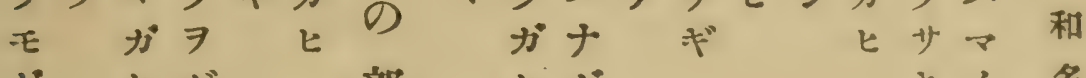

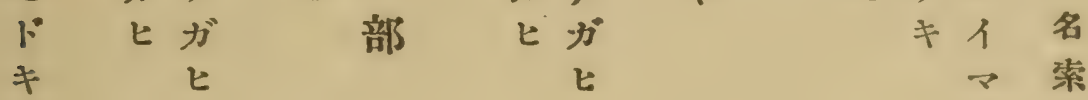

イ 引

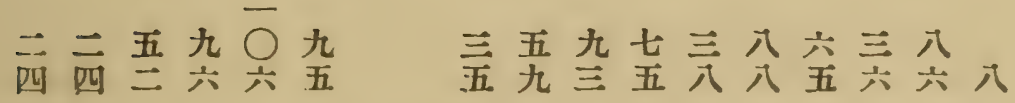

オオオオオオオオオオオオ项

こニナキキマキマキキキキキキキギ゙ッ

马アジニナイナイナナナシシア オ 将スチ

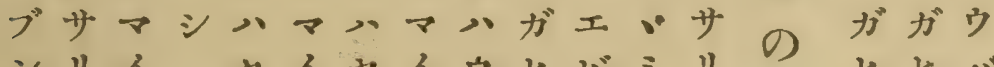

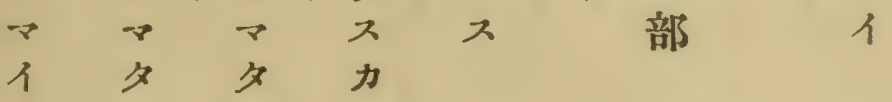

シ カ

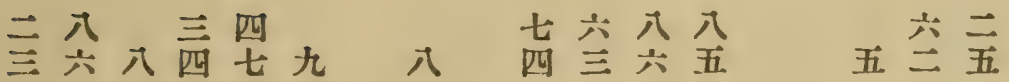

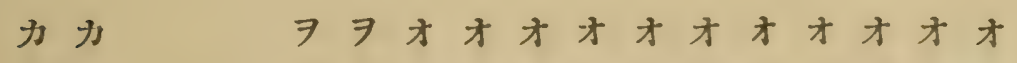

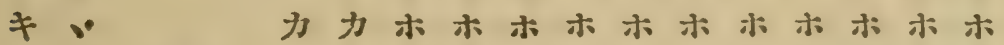
心゙わモミリヤモマへノタケクキイ イのノりママリビガニマチセト の アガキタ;ガガヒジイキルカ

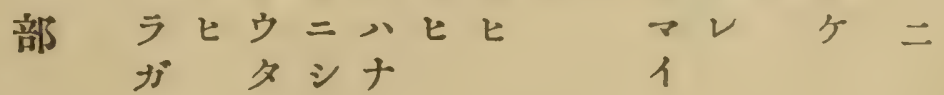

七 ケ

$\vec{O}$ 量 $\quad \therefore$ - 


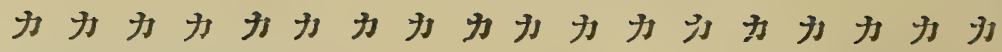
リリラヤメモミハハハにニジタタサコ ナガスノガメソニシアコモノラマッガ 和

名 りネガミヒガりナンヒりうガイムヒラ

索

引

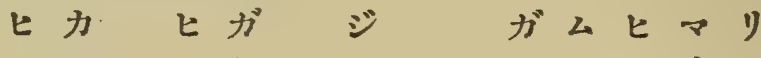

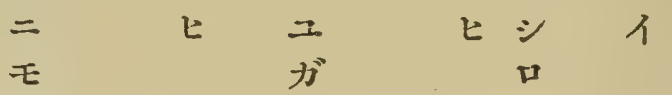

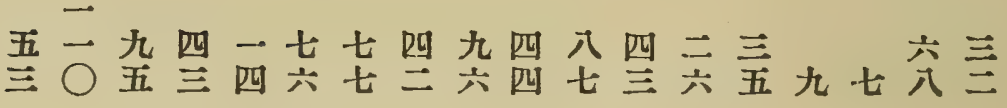

ギキキキキキキキキキキキキキ

ンシヌヌビバッ少クククカエイ

タ、ザガガタネゴノスザイボ口キ ゼ カガルサヒケガ ハ・ルキラタ

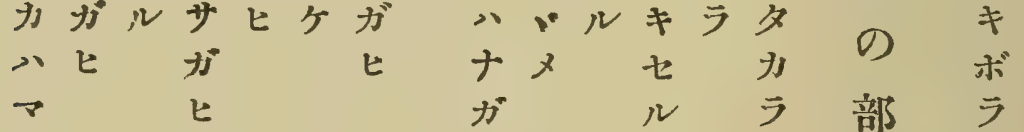

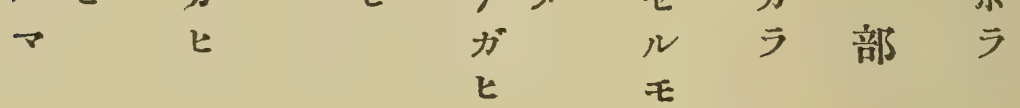

ド

乎

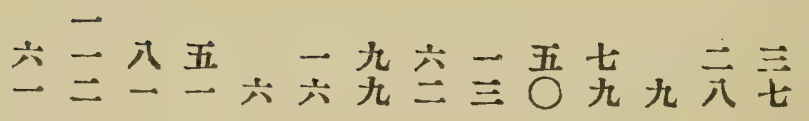

芚

ケケクリククククククククククク

八ガ ロ品ロルモママビ八ヂダ

ダ匕ケミッ゙シザマガノサキノヤキャク

ヒのナケエメカ゚ヒコカレミクレキ

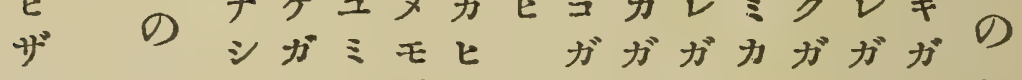

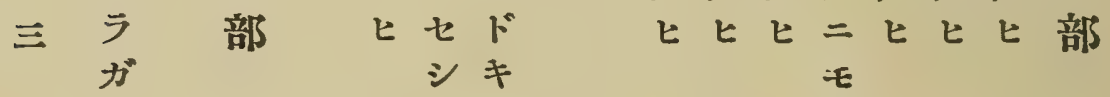

七

y.

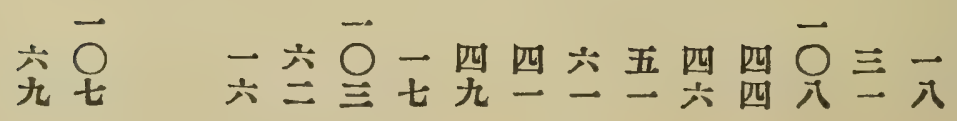


サササコココゴロ゙ゴコココココロ゙

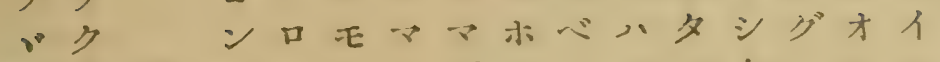

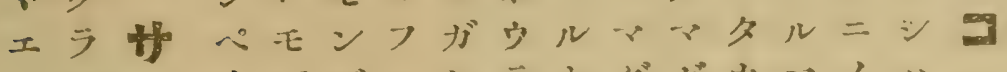

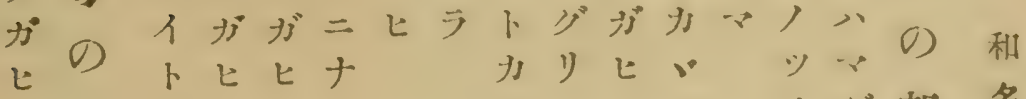
部り

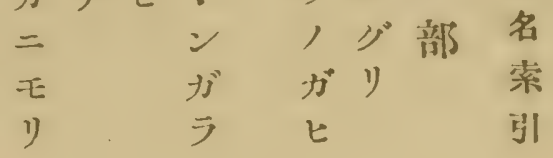

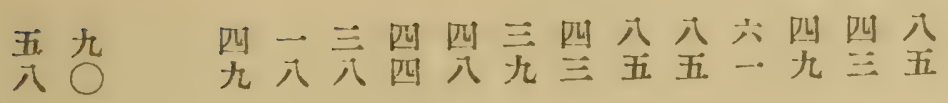

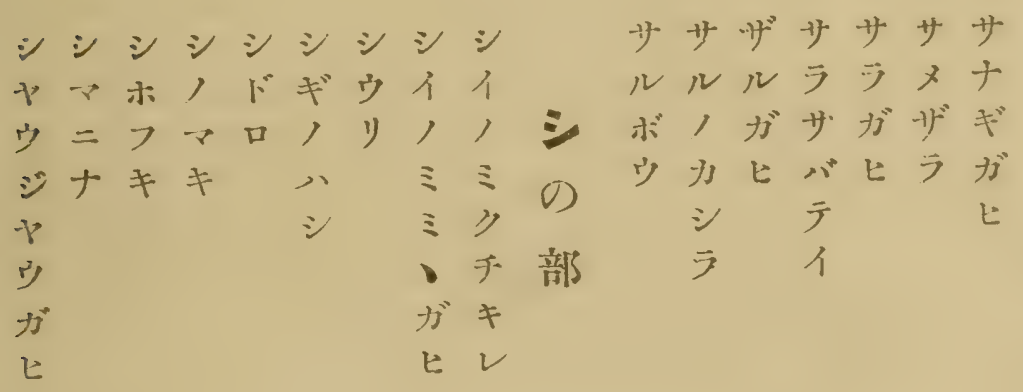

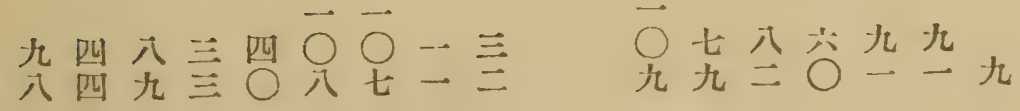

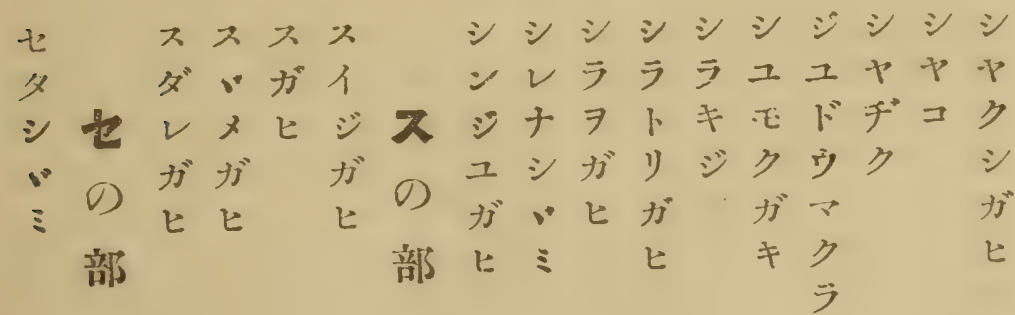

四

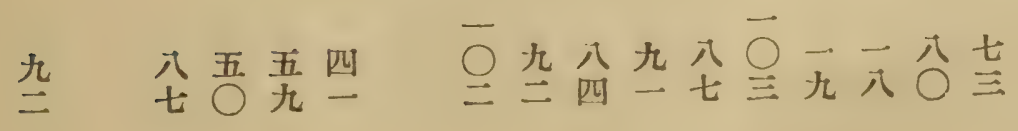




$$
\begin{aligned}
& \text { ダタタタタタタダタセ り } \\
& \text { シママヒニコケカウイド・卜卜 }
\end{aligned}
$$

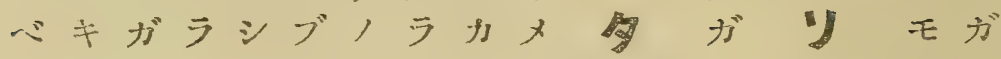

和 $\neq$

名少

索 ゴ

引

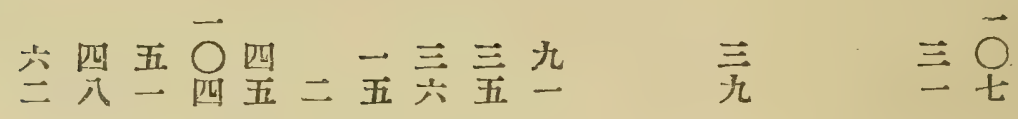

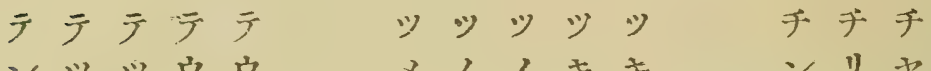

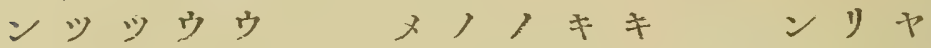

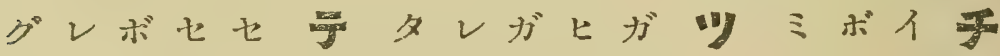

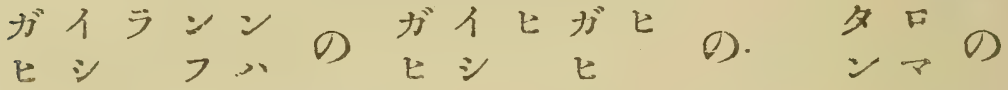

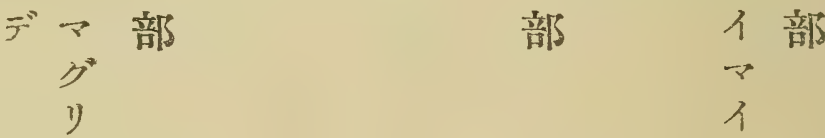

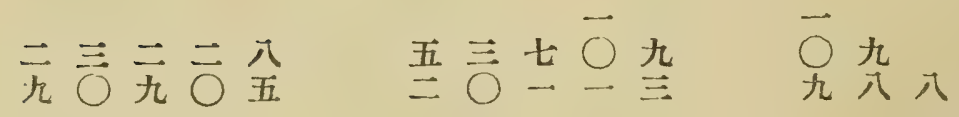

\section{五}

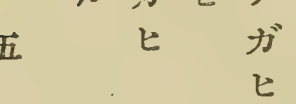

ナナナナナナナナ

トトトドドト

ミデツガガガガガ

乎シメ

せコガ办シニ 手

ルガ匕メ $シ コ$

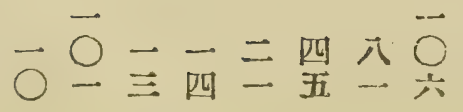

忩吾卆旮杂空
リミマブブコ

†ガガヤシ 狜プトグ

の ヒレガミヒシ

部

部 


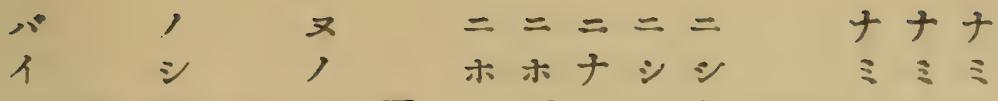

$$
\begin{aligned}
& \text { 八がノメ又ンガかキキ二マンノコ }
\end{aligned}
$$

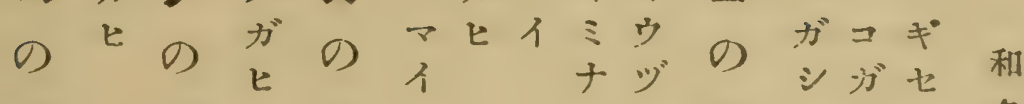

$$
\begin{aligned}
& \text { 部部部マイシ シ 部いヒル名 } \\
& \text { 引 } \\
& \text { 吾吾分盲全立立立 }
\end{aligned}
$$

ヒヒヒヒヒヒヒ バトダタザガア リスリチラヒフ ガヂマオガ ギ ヒマキビヒ

$$
\begin{aligned}
& \text { 人? } \\
& \checkmark 1 \\
& \text { イ? }
\end{aligned}
$$

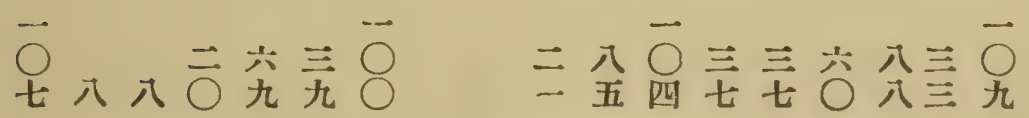

プフフ ヒヒ ヒヒヒヒヒヒヒヒヒヒ テデヂロルマラララメメメメメメメ

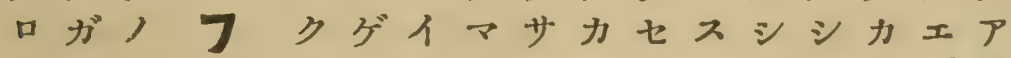
卜七八チンマキ・メトダララン゙サ ラナのカマイミエガモレトクスボり キ 部ノイヅヒノリシガラ $\begin{array}{lll}\exists & \text { カ } & \text { ガ匕 } \\ \text { ガ } & \text { 七. }\end{array}$ ヒ

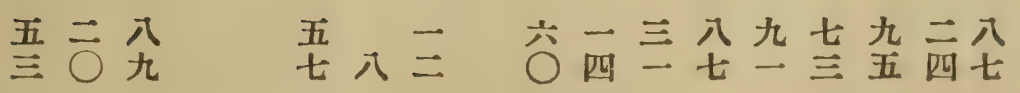




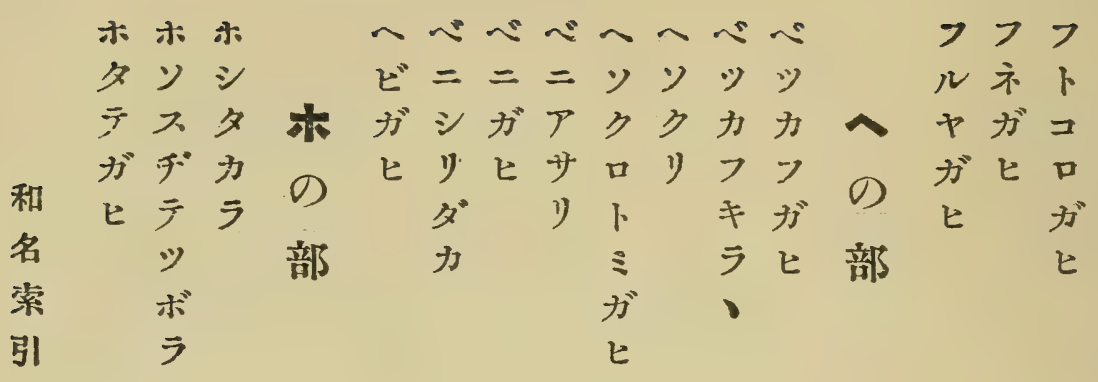

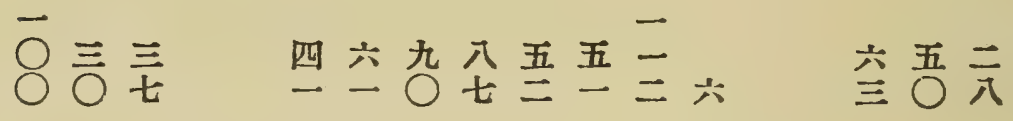

ホホホホホ ラ六卜 マガガ、キル の ヒヒギガガ

部 ヒ ヒ ヒ

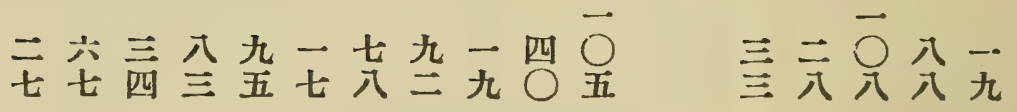

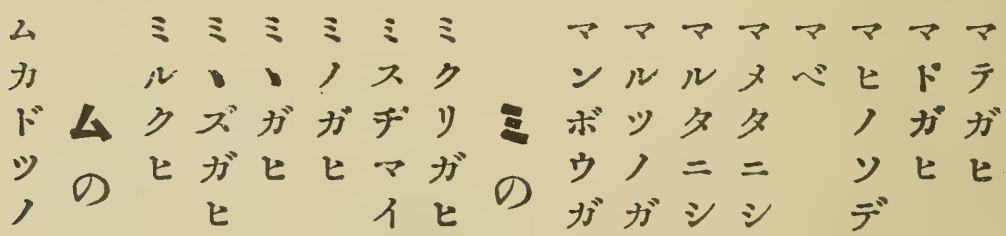

七 ガ 部

$\checkmark$ 部 ヒ ヒ

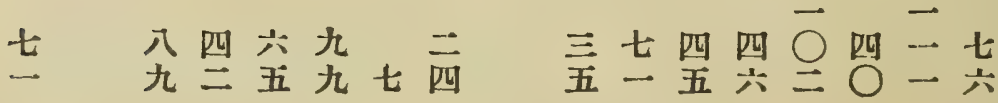




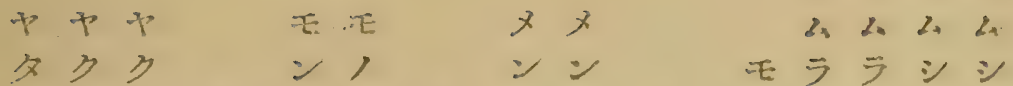

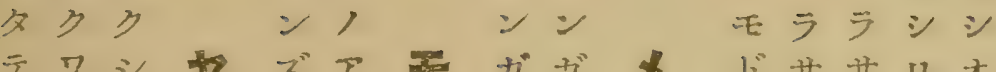

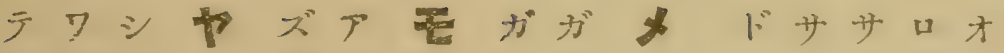

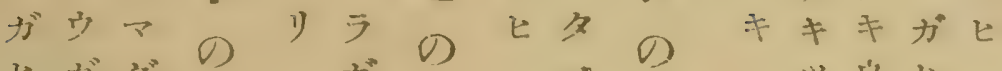

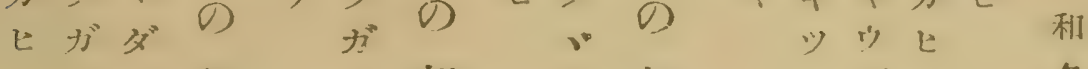

$$
\begin{aligned}
& \text { 七刀部比部少部州 } \\
& \text { ラ }
\end{aligned}
$$

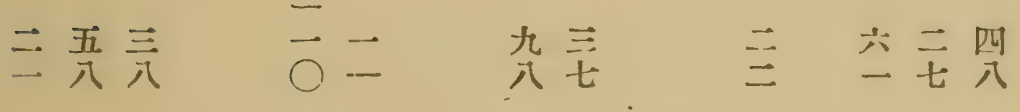

リリリリ リ リ リ

ウリウッウウウ

キキキキキキキ

ウウウウウウウ

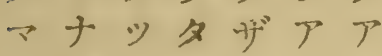

フデノケルフ

ホシ・为比

$$
\text { בタ }
$$

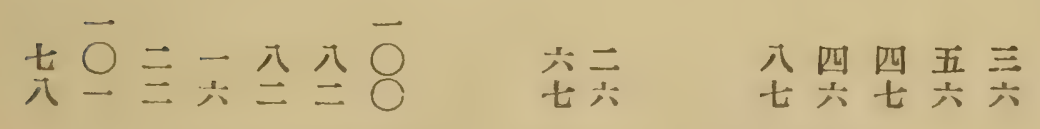
1) ガバ
の)
部
$\vec{\nabla} \vec{\nabla}$
ブタクキシ
キニルサロ
の 少
シ $\rightarrow$ I
部
匕

$p p+p$

$$
\begin{aligned}
& \begin{array}{lllll}
ワ & \text { レ } & \text { リ } & \text { リ } \\
\text { ス } & \text { イ } & \text { リ } & \text { ン }
\end{array} \\
& \text { レワンレガルボテキ } \\
& \text { ザ の の } \\
& \text { 部部部七穴 } \\
& \text { シ }
\end{aligned}
$$
公
0
吾
吾四 


\begin{tabular}{|c|c|}
\hline Stomatella $\quad$.................. 62 & $\begin{array}{r}\text { Page. } \\
\ldots .58,59\end{array}$ \\
\hline Stomatia ................. $6 ?$ & Turricula \\
\hline trombus ................39, 40 & \\
\hline Stylommatophora ........... 5 & U \\
\hline Submytilacea ................. 92 & Umbonium \\
\hline Succinea..................... 6 & Unionidae .. \\
\hline unetta ................... 85 & V \\
\hline $\mathrm{T}$ & Vasum \\
\hline T'cenioglossa $\ldots$. & Veneracea \\
\hline Tapes ....................... 87 & Venus $\ldots$ \\
\hline Tectibranchiata ............. 12 & Vermetus \\
\hline Tellina ...................90, 91 & Viviparus. \\
\hline Tellinacea ................ 87 & Vola ....... \\
\hline Terebra ....................... 16 & Voluta ... \\
\hline Tetrabranchiata .............. & Volva \\
\hline Thecosomata ................ 14 & \\
\hline Thylacodes ................ 41 & $X$ \\
\hline Toxoglossa .................... 15 & Xenophora \\
\hline Tresus $\quad \ldots \ldots \ldots \ldots \ldots \ldots \ldots . \ldots . \ldots 9$ & \\
\hline Tridacna $\ldots . . . . \ldots \ldots \ldots \ldots . . . . .81$ & Y \\
\hline Trishoplita ................ 8 & Yoldia \\
\hline Trochus ...............60, 61 & \\
\hline Truncatella ................ 4 & $\mathbf{Z}$ \\
\hline T'urbinellidee & Zonitidce \\
\hline
\end{tabular}




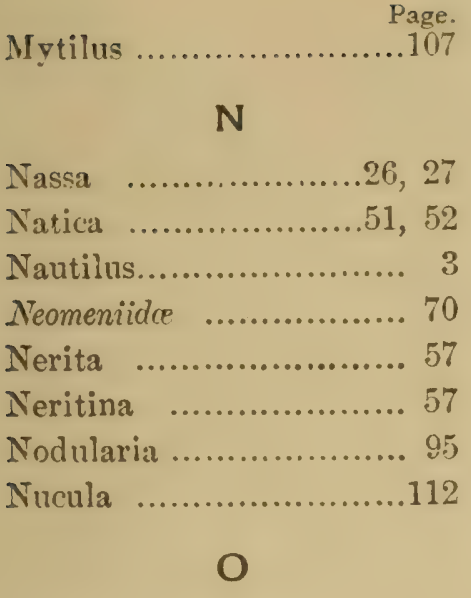

Octopodu ................... 2

Oliva ........................ 19

Olivella ...................... 19

Opisthobranchiata ........... 12

Ostræea ...............105, 106

Ovula ....................... is

\section{$\mathrm{P}$}

Patellide 67

Pecten 100,101

Pelycypoda 72

Peristernia 22

Petricola ................. \&?

Pharince ................... 76

Plioladacea ................. 75

Pholadidea ................ 76

Pholas .................... 75

Pinna .........................104

Placenta ...................111

Planaxis .................. 44

Planorbis . ................. 12

Platypoda ................... 32

Pleurotoma ................. 18

Pleurotomaria ..............68 63

Polinices
Polyplacophora

Page.

Potamides 68

Prosobranchiata 44

Protobranchiata 14

Psammobia 112

Pseudolamellibranchiata..... 97

Ptenoglossa ................. 54

Pteria ......................102

Pterocera ................... 41

Pteropoda .................... 1?

Pterotrachra .............. 53

Pulmonata .................... 5

Pupillidce .................... 9

Pupinella .................. 48

Purpura ..............29, 30

Pyramidella ............31, 32

\section{$\mathrm{R}$}

Rachiglosse ................ Is

Rapana ...................... 29

Rhipidoglossc ............. 56

\section{S}

Saxidomus................... 86

Scala ....................... 55

Scaphoporla ................ 70

Septibranchiata ............. 73

Septifer ......................108

Siliquaria .................. 42

Siphonalia $\ldots . . . . . . . . . .24$

Siphonaria ............... 13

Solarium ................. 49

Solecurtus .................. 77

Solen ....................... 77

Soletellina ................ 90

Sphærium ................. 93

Spiropoma.................. 47

Spondylus ................. 98 


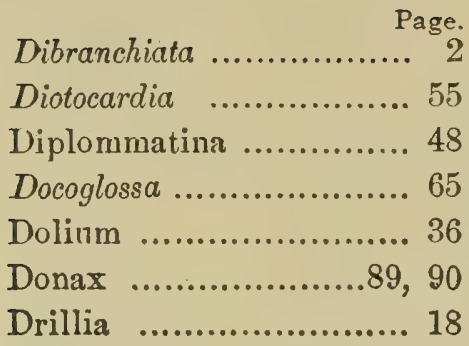

E

Eburna ........................ 25

Echinella ................... 49

Ena........................... 9

Engina ..................... 25

Eulamellibranchiata ........ 74

Eulima ..................... 31

Eulota ..................... 8

Euthria .................... 25

F

Fasciolaria ................. 22

Fusus

G

Ganesella ................... 9

Gastropoda ................ 4

Glycimeris...................110

Gomphina ................ 85

Gymnoglossa ................. 30

Gymnosomata ............. 14

G.vrineum .................. 34

\section{$\mathrm{H}$}

Haliotis .................. 64

Helcioniscus ................ 67

Helicidce ...................... 6

Helicina ................... 56

Hemicardium ............. 82

Hemifusus................... 23
Heteropoda ................... 53

Hirasea ...................... 5

Hyriopsis .................. 95

\section{I}

Ianthina $\quad . . . . . . . . . . . . . . . .554$

K

Kaliella .................... 6

L

Latirus ...................... 22

Lima ........................ 99

Liolophura ................ 69

Lithophaga .................108

Littorina .................. 48

Lucina ..................... 99

Lymnæa $\quad$.................... 11

\section{M}

Macoma ................... 91

Macrochlamys ............. 6

Mactra ...................88, 89

Malleus .....................103

Mandarina ................ 9

Margaritana ............... 96

Melania ...................... 42

Meleagrina .................102

Meretrix .................. 85

Mitra ….............20, 21

Modiola .............107, 108

Mollusca ..................... 1

Monodonta ................ 62

Monotocardia ................ 15

Murex ....................28, 29

Mya ....................... 78

Myacea .................... 76

Mytilacea ..................106 


\section{N D E X.}

\begin{tabular}{|c|c|}
\hline A & Cardiacea \\
\hline Acanthochites .............. 699 & $\begin{array}{l}\text { Cardiaced } \\
\text { Cardita ... }\end{array}$ \\
\hline Acmæa ................6. 65,66 & Cardium \\
\hline Alyciens $\quad \ldots . . .$. & Carinaria \\
\hline Amalthea ........ & Cassidula \\
\hline Amplineura & Cassis ...... \\
\hline Amusium ..................101 & Carolinia \\
\hline Anatina ..................... 74 & Ceplealopodie \\
\hline Anatinacen ........ & Cerithium \\
\hline Anomia ............ & Chretoderma.. \\
\hline Anomicced ...................110 & Chama ......... \\
\hline Aplacophora ................. 70 & Chitonidee ...... \\
\hline A pollon ..................... 34 & Chlorostoma .... \\
\hline Aquillins , ...............32, 38 & Chrysodomus \\
\hline Arca ................109, 110 & Circe ........... \\
\hline Areacea $\ldots . . .$. & Clausilia \\
\hline Argonauta & Columbella . \\
\hline Asaphis ....... & Conus $\quad . . . . .$. \\
\hline Astarte ....... & Corbicula \\
\hline Astralium.... & Crepidula \\
\hline A uricula $\ldots \ldots . .$. & Cristaria \\
\hline B & $\begin{array}{l}\text { Cuspidaria.. } \\
\text { Cuvierina .. }\end{array}$ \\
\hline Basomatophore & Cyclina ... \\
\hline Blanf & Cyclophorus \\
\hline ….......... 25 & Cyclotus ........ \\
\hline Bulla ....... & Cyprea ..................37, 38 \\
\hline C & 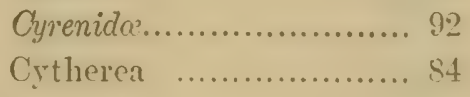 \\
\hline Calliostoma ... & \\
\hline Calyptrccidre & $\mathrm{D}$ \\
\hline Cancellaria & Dentalium \\
\hline
\end{tabular}


明明
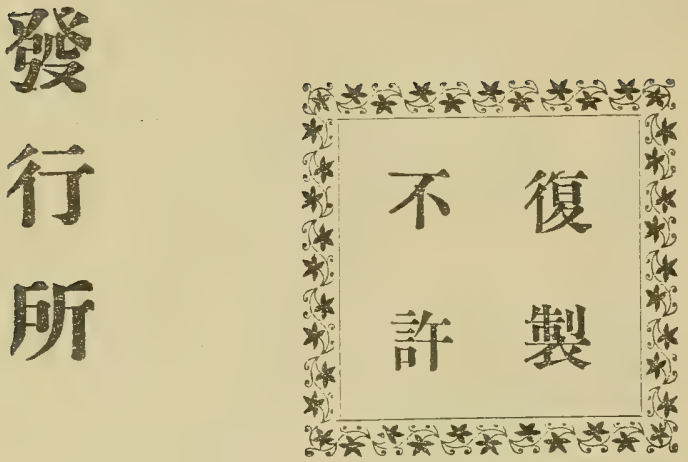

治 治

行

所

出合亭

都

御市

阴上印上印發著

京

前區

刷

刷行作

所

者

者拿

四四

拾拾

武武

年 年

共少

月月

十五

H $\mathrm{B}$

签印

行刷

平

神

部

龍京

戸

Fi

前都

南业市部市

合福 元 营 元 留拾上

資畐町

IIII

四京

番區

會印 通

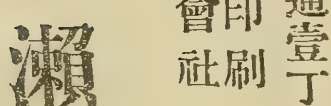

間壹 瀨追鳥

丸

証具德萛

四

介

戶番

支敷次敷

避

T

與

長

正

偲

金

七

町

L

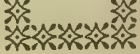

舘

郎

郎 


$$
\text { . }
$$




\section{第列陳類介}

助賛氏瀨平

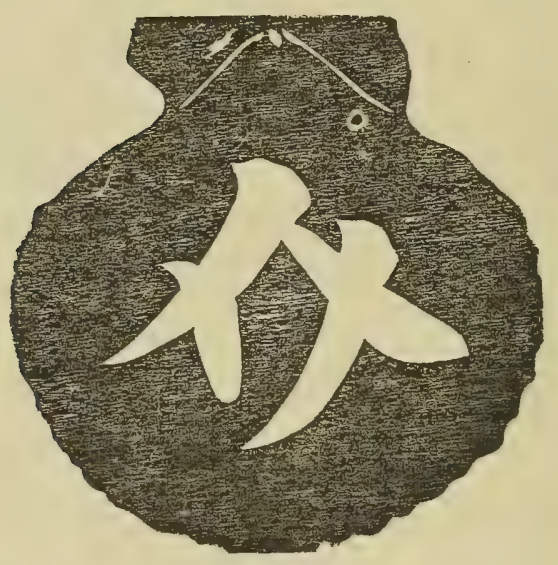

二舞

傿

丁子

子

西

海公

介

演園

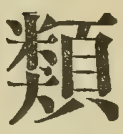

舒 


$\begin{array}{llll}\text { 價 }^{\circ} & \text { 學 } & \text { 標 }^{\circ} & \text { 日 }^{\circ} \\ \text { 格 }^{\circ} & \text { 名 } & \text { 本 } & \\ & & \end{array}$

ば當費當れ當學當舘平 次出舘府舘ば舘術舘精瀨 に來の可産の界は撰介 標得目ピ標地標に尔 準限にスは精は献與 價りよブ先碓特せ一

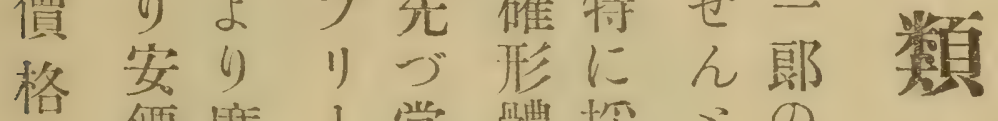
を價鹰】當體探この

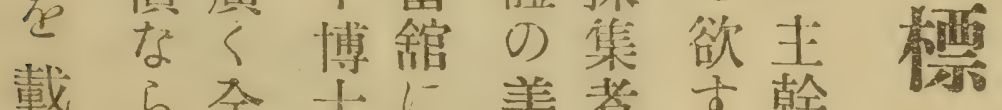
土全世美若9 幹 すん般のて 共をるす

こに再精に使にる

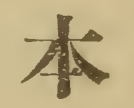

且調查乎而市所 を研死亡 ふしりに 欲究煩後名生 せには更の介 り凟し行な虎 せた斯し捕類 んる界獲の こ它 せ 研 の 泰し究 るな斗好灰 もりた ᄂ 以

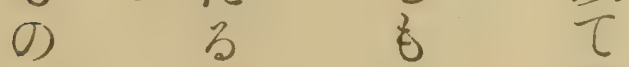
な 米の聊 れ國な 少 
00000

外涌一右街

國例種は造

產標等標費

具本に準及

類圭藏顀遞

3 組别格䢪

需已し老料

に尔收示等

應古容しは

末と过杞代

べさんる傮

しはがるの

海雼の外

京產め梠に

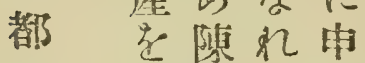

古主列ば受

蛤异用珍く

御しの敷べ

明陸小纪

明。產箱の

前展老稀

㵪要初

水颃㷊

產るる

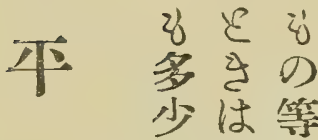

加别は

叨 入に此

生代限

る徨 り

当索に

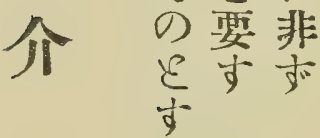

\begin{tabular}{|c|c|}
\hline 梦 熘 準 標 & \\
\hline 千九公尤五四三二百五 & 種 \\
\hline 百百自百百百百百 十 & 類 \\
\hline 種種種種種種種 種 種 種 種 & 數 \\
\hline 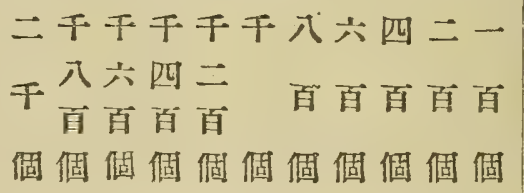 & 個 \\
\hline 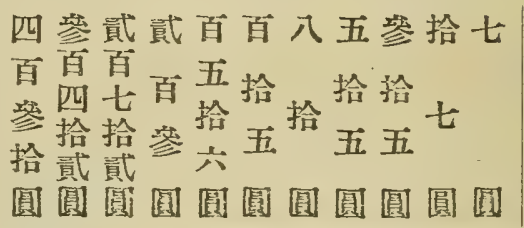 & $\begin{array}{l}\text { 一 } \\
\text { 等 } \\
\text { 品 } \\
\text { 代 } \\
\text { 楅 }\end{array}$ \\
\hline 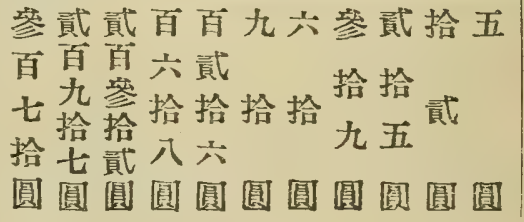 & $\begin{array}{l}\text { 三 } \\
\text { 等 } \\
\text { 品 } \\
\text { 代 } \\
\text { 傊 }\end{array}$ \\
\hline
\end{tabular}

百百百六武

七杂參拾拾拾拾拾拾武

拾七筫八六

圆圆圓圆圓圆圆圆圆圆圆傾

\section{舘}




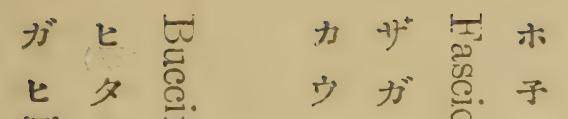

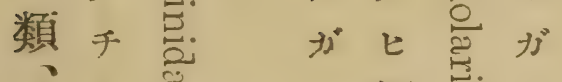

キ オ气゙第七類 冚 七 第

ビ ビエ三類 き五科—

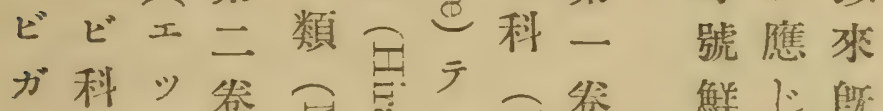

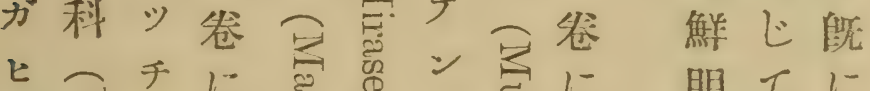

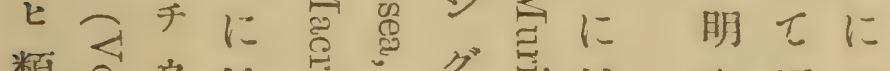

類号於苍於

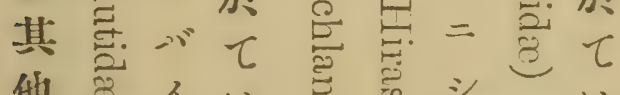

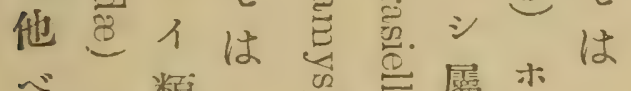

ベフ類

シデョ

クガフ

カ ヒ バ

七科

科量科

の

全 焉密

部べ

をッォ

丁 $\Rightarrow$ 才

$3>=$

ガ ブ

上 シ

屬科

完

了.

$\rightarrow$ :

, 总

八

) है
りの類 本

如走 婄

乙\& 創

临時刊

每に以

介

紹三類

当介年

第公米

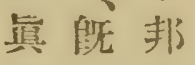

版に版

三海 圖

梲陸に

宛產屬

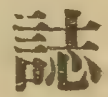

责具。

插類る

入の各

乙記地

各载方

種过は

にら忽

就れ諭

对れ韓

慇吕國

切的及

にのび

記 實清

逝に國

乙左產

机表具 
月笖侣犯は具第模 因第俳ば國談二式》

に 万四九苂書漫號フ

第化號台學介録にトが第

一代引赽走者名は亘コヒ忽

总㵋續以失の教有り口科然

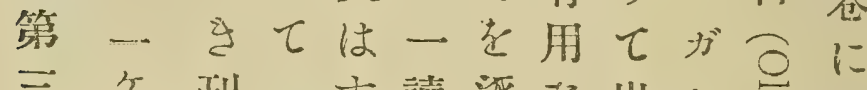

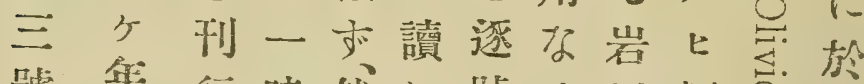

號等行時然に號占川類连七

は多の休る当揭筫区

京缺前箈刊に價戴用の尽

都號金にの今主純的本吉

市せ圆し止や佮國介邦总》

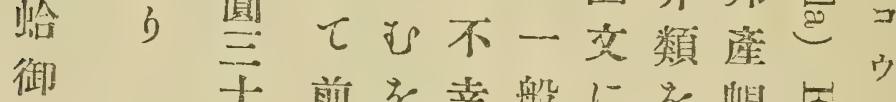

䦕

前

4:

十前を幸般に苍蜆导う

錢々得に介て講類落

郵にざし類古迅の导科

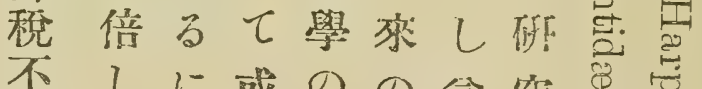

不しに或のの軦究焉。

要—至る智具名㠿导

層号事識名佳揭突

一の然情及㸴境げ芯。”

溯部良れに時管にれるヌ

見誌电よ報せ入り、其が

本打來 はらら其完七

介郵らる本愛就几他了科

税九四年介れと每殊尽

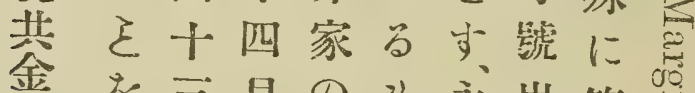

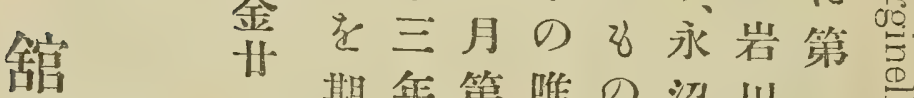

世期年第唯の沼川一总

鈛す五三一沓氏號总 
五与右 種へは ○小 夫美供

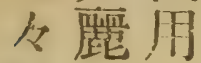
種なこ 類るし 異紙て る箱製 $\checkmark i$ 京毁入た 都に犳る 梁調夫㐘 蛤製々の 御せ利に 門り名し 前

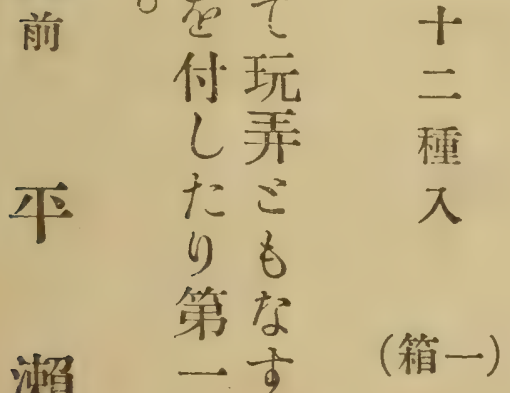

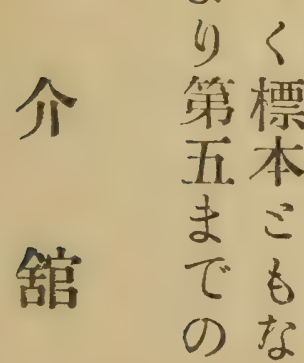

金代

二 儧

十型 錢共

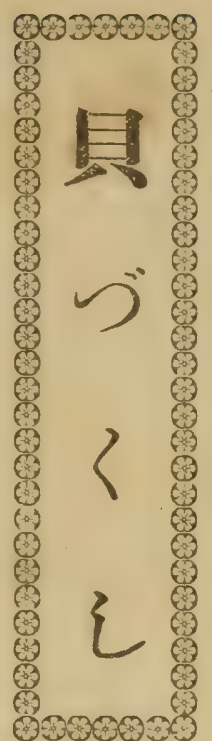

贈橴不 物びの に優大 適美中 しな小 或る三 は裝稞 美飾の 術存箱 工加は 藝へ各 家た買 のるり 好桐た 參のる 考箱䄈 資に類桐十 料入に た礼し

るたて べ何

しもれ價代 $\circ の$ \& に美 小小中大 しは包金金金 てし新六二 觀き士十睍 裳の錢錢錢圆 は存

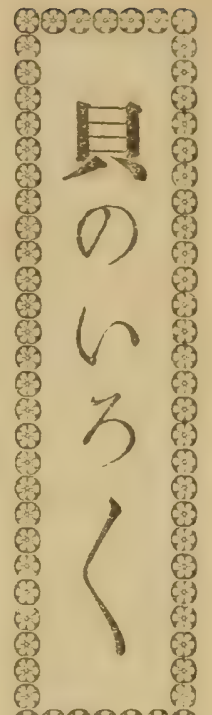

箱 入宛 




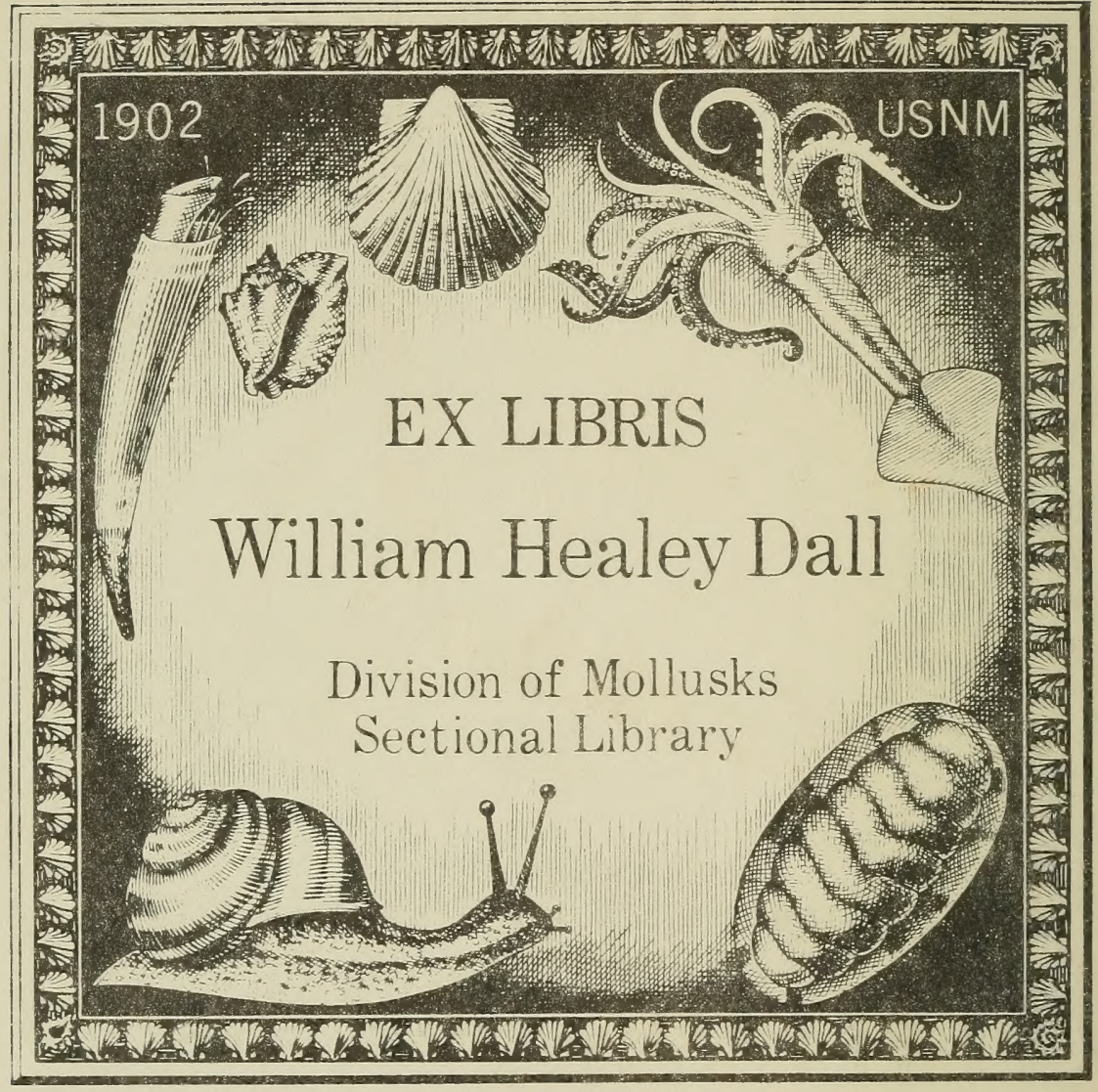


